NORA KATIA SAAVEDRA DEL AGUILA

\title{
AVALIAÇÃO DE BACTÉRIAS FOTOTRÓFICAS EM LAGOAS DE ESTABILIZAÇÃO: DIVERSIDADE, PURIFICAÇÃO E IDENTIFICAÇÃO
}

Tese apresentada à Escola de Engenharia de São Carlos, da Universidade de São Paulo, como parte dos requisitos para obtenção do título de Doutor em Hidráulica e Saneamento.

Orientadora: Profa. Dra. MARIA BERNADETE A. VARESCHE

São Carlos

2007 
AUTORIZO A REPRODUÇÃO E DIVULGAÇÃO TOTAL OU PARCIAL DESTE TRABALHO, POR QUALQUER MEIO CONVENCIONAL OU ELETRÔNICO, PARA FINS DE ESTUDO E PESQUISA, DESDE QUE CITADA A FONTE.

Ficha catalográfica preparada pela Seção de Tratamento da Informação do Serviço de Biblioteca - EESC/USP

S112a Saavedra del Aguila, Nora Katia

estabilização : diversidade, purificação e identificação / Nora Katia Saavedra del Aguila ; orientadora Maria Bernadete A. Varesche. -- São Carlos, 2007.

Tese (Doutorado-Programa de Pós-Graduação e Área de Concentração em Hidráulica e Saneamento) -- Escola de Engenharia de São Carlos da Universidade de São Paulo, 2007.

1. Lagoas de estabilização. 2. Diversidade microbiana. 3. PCR-DGGE. 4. Seqüenciamento de fragmentos do gene RNAr 16S. 5. Bactérias fototróficas púrpuras. I. Título. 


\section{FOLHA DE JULGAMENTO}

Candidata: Bachiller NORA KATIA SAAVEDRA DEL AGUILA

Tese defendida e julgada em 01/06/2007 perante a Comissão Julgadora:

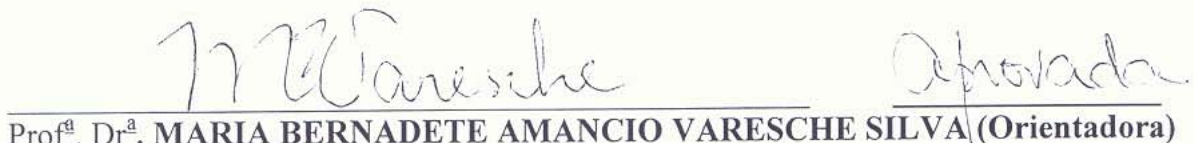
Prof ${ }^{a}$. Dr ${ }^{\mathrm{a}}$. MARIA BERNADETE AMANCIO VARESCHE SILVA|(Orientadora) (Escola de Engenharia de São Carlos/USP)

Nrdui C.A. des Solat

APROVADA

Prof. Dr. ANDRÉ CORDEIRO ALVES DOS SANTOS

(Universidade Federal de São Carlos/UFSCar - Campus de Sorocaba)

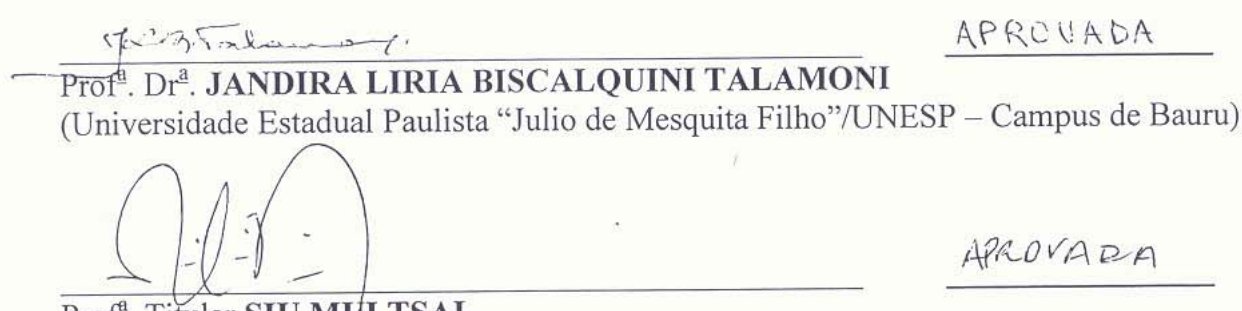

Prof ${ }^{\mathrm{a}}$. Titular SIU MUI TSAI

(Centro de Energia Nuclear na Agricultura/USP)

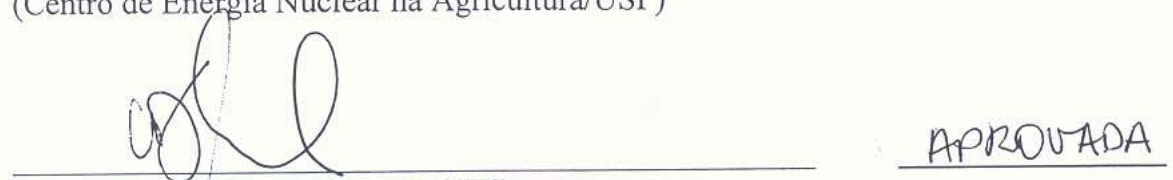

Prof. Dr. CARLOS DIASS MACIEL

(Escola de Engenharia de São Carlos/USP)

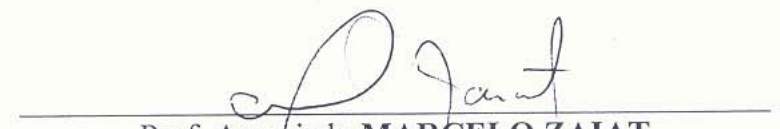

Prof. Associado MARCELO ZAIAT

Coordenador do Programa de Pós-Graduação

em Engenharia (Hidráulica e Saneamento)

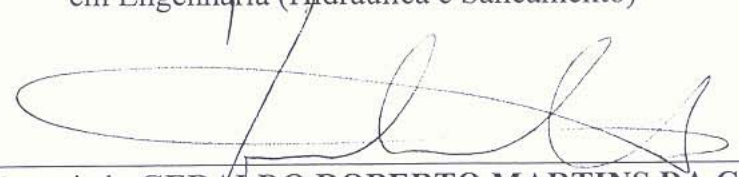

Prof. Associado GERALDO ROBERTO MARTINS DA COSTA

Presidente da Comissão da Pós-Graduação da EESC 

Dedico este trabalho aos meus pais Marcial e Belén e aos meus irmãos Leslie e Juan. 

Todo pasa y todo queda, pero lo nuestro es pasar, pasar haciendo caminos, caminos sobre el mar.

Caminante, son tus huellas el camino y nada más, caminante, no hay camino, se hace camino al andar. 



\section{AGRADECIMENTOS}

À minha orientadora professora Dra. Maria Bernadete A. Varesche Silva pela dedicação, paciência, estímulo, valiosa orientação, confiança, amizade e por estar sempre presente.

Ao Prof. Dr. Carlos Dias Maciel pelo apoio na realização e análises dos dendrogramas.

À Prof ${ }^{\mathfrak{a}}$ Titular Dra. Maria do Carmo Calijuri pelo apoio na realização da presente pesquisa.

Ao Dr. Fábio A. Chinalia e à Dra. Isabel K. Sakamoto pelo ensinamento das técnicas da biologia molecular.

Ao Departamento de Hidráulica e Saneamento da EESC-USP, pela estrutura fornecida para desenvolvimento deste trabalho; em especial a Pavi e Sá pelo valioso apoio e carinho que me brindaram. E a Rose pela alegria compartilhada.

À minha adorada família, pela presença constante em todos os momentos da minha vida: meus pais Marcial e Belén; irmãos Leslie e Juan, e lindos sobrinhos Leslita, Oscar Martín e Juan Vinícius.

À Prof ${ }^{a}$. Elisabeth Moraes e a Maria Ângela Adorno, pela ajuda e apoio nas análises de ácidos orgânicos voláteis, e o mais importante, pela atenção e carinho.

À Dra. Iolanda Cristina Silveira Duarte pela amizade e pelas sugestões e auxílio neste trabalho.

Ao CNPq pela concessão da bolsa de estudos.

À FAPESP pelo apoio financeiro ao Projeto Temático da qual formou parte a presente pesquisa. 

Aos técnicos que participaram das coletas, Valdomiro Antônio Filho, José Roberto Maramarque, e ao Benedito Patracon.

Às minhas lindas amigas Sandra, Lorena, Kelly, Cláudia, Mercia, Lara e Luana, pelo carinho, risadas e apoio constantes.

Aos meus queridos amigos Giancarlo, Katlin, Rosamel, Maribel, Patricia e Katherine pelo carinho, alegria e momentos de descontração.

A todos os amigos e colegas do Laboratório de Processos Biológicos (LPB-SHS).

A todos os amigos e colegas que fiz na cidade de São Carlos.

A todos que contribuíram de alguma maneira para a realização deste trabalho. 



\section{RESUMO}

SAAVEDRA, N.K. (2007). Avaliação de bactérias fototróficas em lagoas de estabilização: diversidade, purificação e identificação. Tese (Doutorado) - Escola de Engenharia de São Carlos, Universidade de São Paulo, São Carlos, 2007.

As bactérias fototróficas freqüentemente apresentam florescimentos em lagoas de estabilização utilizadas no tratamento de esgoto sanitário, formando uma camada de cor púrpura na sua superfície. Portanto, o estudo das condições que propiciam tais florescimentos, a diversidade microbiana, o potencial de remoção da matéria orgânica e o estabelecimento das relações entre tais conhecimentos, permitem compreender o metabolismo do sistema. Nesse sentido, o objetivo deste trabalho foi avaliar a diversidade de bactérias (Domínio Bacteria), bactérias fototróficas púrpuras e bactérias redutoras de sulfato (BRS) em lagoas de estabilização do Vale do Ribeira (Cajati, SP). Para tal, foram realizadas coletas sazonais (primavera, verão, outono e inverno) na sub-superfície, camada intermediária e interface água-sedimento, em dois horários (14:00 h e 02:00 h), nas lagoas anaeróbia e facultativa. Para analisar os diferentes grupos de microrganismos, utilizou-se a técnica de PCR/DGGE, com primers específicos. Nas análises de filogenia realizou-se o seqüenciamento parcial do gene RNAr 16S e da subunidade M do centro de reação fotossintético das bactérias fototróficas púrpuras. Análises físico-químicas, tais como sulfato, DQO, sólidos, nitrogênio e fósforo foram realizadas, além da determinação da concentração de oxigênio dissolvido, $\mathrm{pH}$, temperatura e radiação solar fotossinteticamente ativa incidente. No outono observou-se maior diversidade de microrganismos do Domínio Bacteria, bactérias fototróficas púrpuras e BRS, enquanto na primavera foi verificada a menor diversidade desses microrganismos para as duas lagoas. Na lagoa facultativa foi observada maior diversidade do Domínio Bacteria e das BRS em relação à lagoa anaeróbia. Verificou-se maior diversidade de bactérias fototróficas púrpuras na lagoa anaeróbia, caracterizada por duas populações predominantes nas quatro estações e nas diferentes profundidades. A concentração de matéria orgânica (DQO) variou de $60,3 \mathrm{mg} / \mathrm{L}$ (inverno) a $298,0 \mathrm{mg} / \mathrm{L}$ (primavera) e a maior concentração de sulfato observada foi de $51,0 \mathrm{mg} / \mathrm{L}$ (inverno). Bacilo curvo Gram negativo, semelhante à bactéria fototrófica púrpura não sulfurosa, presente em amostra proveniente da sub-superfície da lagoa anaeróbia foi purificado e apresentou 92\% de similaridade com Rhodopseudomonas palustris. Em ambas as lagoas foram identificadas bactérias semelhantes a Chromobacterium suttsuga (95\%), Clostridium sp. (99\%), Rhodobacter sphaeroides (99\%), Rhodopseudomonas palustris (99\%), Lampropedia hyalina (97\%), Campylobacter fetus (99\%), Desulfovibrio vulgaris (95\%), Rhodospirillum rubrum (95\%) e diferentes bactérias não cultivadas.

Palavras chave: lagoas de estabilização, diversidade microbiana, PCR-DGGE, seqüenciamento de fragmentos do gene RNAr 16S, bactérias fototróficas púrpuras. 


\begin{abstract}
SAAVEDRA, N.K. (2007). Evaluation of phototropic bacteria in stabilization lagoons: diversity, purification and identification. Tese (Doutorado) - Escola de Engenharia de São Carlos, Universidade de São Paulo, São Carlos, 2007.
\end{abstract}

The phototrophic bacteria frequently blossom in the stabilization lagoons that are used in sanitary sewer treatment, forming a purple layer on its surface. Therefore, the study of the conditions that propitiate such blooms, the microbial diversity, the removal of the organic matter and the establishment of the relations between them permit to understand the metabolism of the system. The objective of this work was to evaluate the diversity of the bacteria (Bacteria Domain), purple phototrophic bacteria and sulfate reducing bacteria (SRB) in stabilization lagoons of "Vale do Ribeira" (Cajati - SP). For this, it was made seasonal collects (spring, summer, autumn and winter) from the sub-surface, intermediate layer and interface water-sediment, at two times (14:00 h and 02:00h) of the anaerobic and facultative lagoons. To analyze the different groups of microorganisms it was used the PCR/DGGE technique, with specific primers; for the phylogenic analysis it was realized the DNA partial sequencing of the 16S RNAr gene and of the subunit $M$ of the photosynthetic center of reaction of the purple photosynthetic bacteria. It was determined: the concentration of dissolved oxygen, $\mathrm{pH}$, temperature and photosynthetically active incident solar radiation, and the physical-chemistry analysis as: COD, solids, nitrogen and phosphorus. In the autumn it was observed greater diversity of microorganisms of the Bacteria Domain, the group of the purples phototrophic bacteria and SRB, while in the spring it was verified minor diversity of these microorganisms in the two lagoons studied. In the facultative lagoon it was observed greater diversity of the Bacteria Domain and of the SRB with respect to the anaerobic lagoon. It was verified greater diversity of the purple phototrophic bacteria in the anaerobic lagoon, of what in the facultative lagoon, which was characterized by the two predominant populations in the four seasons and in the different points of collect. The concentration of the organic matter (COD) varied from $60,3 \mathrm{mg} / \mathrm{L}$ (winter) to $298,0 \mathrm{mg} / \mathrm{L}$ (spring) and the greater concentration of sulfate observed was of $51,0 \mathrm{mg} / \mathrm{L}$ (winter). Arched bacillus Gram-negative similar to purple not sulfurous bacteria, from a sample of the sub-surface of the anaerobic lagoon was purified and presented $92 \%$ of similarity with Rhodopseudomonas palustris. In both lagoons it was identified bacteria similar to Chromobacterium suttsuga (95\%), Clostridium sp. (99\%), Rhodobacter sphaeroides (99\%), Rhodopseudomonas palustris (99\%), Lampropedia hyalina (97\%), Campylobacter fetus (99\%), Desulfovibrio vulgaris (95\%), Rhodospirillum rubrum (95\%).

Key words: stabilization lagoons, microbial diversity, PCR-DGGE, sequencing of $16 \mathrm{~S}$ RNAr fragments, purple phototrophic bacteria. 


\section{LISTA DE FIGURAS}

Figura 3.1 Centro de reação fotossintética das bactérias púrpuras (operon puf) 26

Figura 4.1. Fluxograma experimental realizado nas lagoas de estabilização 34

Figura 4.2. Lagoas de estabilização anaeróbia e facultativa de Cajati 36

Figura 4.3. Fluxograma da purificação de bactérias fototróficas púrpuras das amostras 41 provenientes das lagoas anaeróbia e facultativa

Figura 5.1. Velocidade do vento em Jacupiranga nos horários e épocas das coletas $\quad 48$

Figura 5.2. Valores de precipitação e de temperatura em Cajati nos horários e épocas $\quad 49$ das coletas

Figura 5.3. Dendrograma das variações sazonais na lagoa anaeróbia com primers para 53 o Domínio Bacteria referente ao horário (T1) (14:00 h)

Figura 5.4. Variação sazonal de pH na lagoa anaeróbia referente ao horário T1 (14:00 h)

Figura 5.5. Variação sazonal da temperatura na lagoa anaeróbia nas diferentes épocas do ano referente ao horário $\mathrm{T} 1(14: 00 \mathrm{~h})$

Figura 5.6. Variações sazonais de oxigênio dissolvido na lagoa anaeróbia referente ao horário T1 (14:00 h)

Figura 5.7. Variações sazonais de sulfato na lagoa anaeróbia referente ao horário T1 $(14: 00 \mathrm{~h})$

Figura 5.8. Variações sazonais de matéria orgânica na lagoa anaeróbia referente ao horário T1 (14:00 h)

Figura 5.9. Variações sazonais de SSV na lagoa anaeróbia referente ao horário T1 $(14: 00 \mathrm{~h})$

Figura 5.10. Variações sazonais de NTK na lagoa anaeróbia referente ao horário T1 $(14: 00 \mathrm{~h})$

Figura 5.11. Variações sazonais de fósforo total na lagoa anaeróbia referente ao horário T1 (14:00 h)

Figura 5.12. Dendrograma das variações sazonais na lagoa anaeróbia com primers para o Domínio Bacteria - 02:00 h (T3)

Figura 5.13. Variação sazonal de pH na lagoa anaeróbia referente ao horário T3 (2:00 h)

Figura 5.14. Variação sazonal de temperatura na lagoa anaeróbia nas diferentes épocas do ano referente ao horário $\mathrm{T} 3(2: 00 \mathrm{~h})$

Figura 5.15. Variações sazonais de oxigênio dissolvido na lagoa anaeróbia referente ao horário T3 $(2: 00 \mathrm{~h})$

Figura 5.16. Variações sazonais de sulfato na lagoa anaeróbia referente ao horário T3 $(2: 00 \mathrm{~h})$

Figura 5.17. Variações sazonais da matéria orgânica na lagoa anaeróbia referente ao horário T3 (2:00 h)

Figura 5.18. Variações sazonais de SSV na lagoa anaeróbia referente ao horário T3 $(2: 00 \mathrm{~h})$

Figura 5.19. Variações sazonais de NTK na lagoa anaeróbia referente ao horário T3 $(2: 00 \mathrm{~h})$

Figura 5.20. Variações sazonais de fósforo total na lagoa anaeróbia referente ao horário T3 (2:00 h)

Figura 5.21. Dendrograma das variações sazonais na lagoa anaeróbia com primers pufM referente ao horário T1 (14:00 h)

Figura 5.22. Dendrograma das variações sazonais na lagoa anaeróbia com primers pufM referente ao horário T3 $(02: 00 \mathrm{~h})$ 
Figura 5.23. Dendrograma das variações sazonais na lagoa anaeróbia com primers para 78 as BRS referente ao horário T1 $(14: 00 \mathrm{~h})$

Figura 5.24. Dendrograma das variações sazonais na lagoa anaeróbia com primers para as BRS referente ao horário T3 $(02: 00 \mathrm{~h})$

Figura 5.25. Dendrograma das variações sazonais na lagoa facultativa com primers para o Domínio Bacteria refente ao horário T1 (14:00 h)

Figura 5.26. Variações sazonais de $\mathrm{pH}$ na lagoa facultativa referente ao horário $\mathrm{T} 1$ $(14: 00 \mathrm{~h})$

Figura 5.27. Variações sazonais de temperatura na lagoa facultativa referente ao 88 horário T1 (14:00 h)

Figura 5.28. Variações sazonais de oxigênio dissolvido na lagoa facultativa referente ao horário T1 (14:00 h)

Figura 5.29. Variações sazonais de sulfato na lagoa facultativa referente ao horário T1 90 $(14: 00 \mathrm{~h})$

Figura 5.30. Variações sazonais de matéria orgânica na lagoa facultativa referente ao horário T1 (14:00 h)

Figura 5.31. Variações sazonais de SSV na lagoa facultativa referente ao horário T1 92 $(14: 00 \mathrm{~h})$

Figura 5.32. Variações sazonais de NTK na lagoa facultativa referente ao horário T1 $(14: 00 \mathrm{~h})$

Figura 5.33. Variações sazonais de fósforo total na lagoa facultativa referente ao horário T1 (14:00 h)

Figura 5.34. Dendrograma das variações sazonais na lagoa facultativa com primers 96 para o Domínio Bacteria referente ao horário T3 $(02: 00 \mathrm{~h})$

Figura 5.35. Variações sazonais de pH na lagoa facultativa referente ao horário T3 98 $(02: 00 \mathrm{~h})$

Figura 5.36. Variações sazonais de temperatura na lagoa facultativa referente ao horário T3 $(02: 00 \mathrm{~h})$

Figura 5.37. Variações sazonais de oxigênio dissolvido na lagoa facultativa referente ao horário T3 $(02: 00 \mathrm{~h})$

Figura 5.38. Variações sazonais de sulfato na lagoa facultativa referente ao horário T3 $(02: 00 \mathrm{~h})$

Figura 5.39. Variações sazonais de matéria orgânica na lagoa facultativa referente ao horário T3 $(02: 00 \mathrm{~h})$

Figura 5.40. Variações sazonais de SSV na lagoa facultativa referente ao horário T3 $(02: 00 \mathrm{~h})$

Figura 5.41. Variações sazonais de NTK na lagoa facultativa referente ao horário T3 $(02: 00 \mathrm{~h})$

Figura 5.42. Variações sazonais de fósforo total na lagoa facultativa referente ao horário T3 $(02: 00 \mathrm{~h})$

Figura 5.43. Dendrograma das variações sazonais na lagoa facultativa com primers pufM referente ao horário $\mathrm{T} 1(14: 00 \mathrm{~h})$

Figura 5.44. Dendrograma das variações sazonais na lagoa facultativa com primers puf $\mathrm{M}$ referente ao horário $\mathrm{T} 3(02: 00 \mathrm{~h})$

Figura 5.45. Dendrograma das variações sazonais na lagoa facultativa com primers para as BRS referente ao horário T1 $(14: 00 \mathrm{~h})$

Figura 5.46. Dendrograma das variações sazonais na lagoa facultativa com primers para as BRS referente ao horário T3 $(02: 00 \mathrm{~h})$

Figura 5.47. Perfis das bandas padrões do DGGE com primers para o Domínio Bacteria na lagoa anaeróbia

Figura 5.48. Perfis das bandas padrões do DGGE com primers pufM na lagoa 
anaeróbia

Figura 5.49. Perfis das bandas padrões do DGGE com primers para as BRS na lagoa anaeróbia

Figura 5.50. Perfis das bandas padrões do DGGE com primers para o Domínio Bacteria na lagoa facultativa

Figura 5.51. Perfis das bandas padrões do DGGE com primers pufM na lagoa facultativa

Figura 5.52. Perfis das bandas padrões do DGGE com primers para as BRS na lagoa facultativa

Figura 5.53. Microscopia óptica de contraste de fase de microrganismos observados na lagoa anaeróbia e na lagoa facultativa (Obj.1600X): (a) $\operatorname{cocos} \mathrm{e}$ diplococos, (b) bacilos e ameba, (c) bacilos, bacilos curvos e filamentos finos, (d) bacilos em cadeia, (e) filamentos finos, cocos e diplococos, (f) protozoário e diplococos

Figura 5.54. Gel de DGGE (gradiente 30\%-70\%) das variações sazonais na lagoa anaeróbia com primers para o Domínio Bacteria referente aos horários T1(a) e T3(b)

Figura 5.55. Gel de DGGE (gradiente 30\%-70\%) das variações sazonais na lagoa facultativa com primers para o Domínio Bacteria referente aos horários T1(a) e T3(b)

Figura 5.56. Árvore filogenética de consenso baseado nas seqüências das bandas recortadas do DGGE com primers para o Domínio Bacteria, obtidas das lagoas anaeróbia e facultativa

Figura 5.57. Gel de DGGE (gradiente 20\%-80\%) das variações sazonais na lagoa anaeróbia com primers puf $\mathrm{M}$ referente aos horários: T1(a) e T3 (b)

Figura 5.58. Gel de DGGE (gradiente 20\%-80\%) das variações sazonais na lagoa facultativa com primers pufM referente aos horários: T1 (a) e T3 (b)

Figura 5.59. Árvore filogenética de consenso baseada nas seqüências das bandas recortadas do DGGE com primers do centro fotossintético puf $\mathrm{M}$, obtidas das lagoas anaeróbia e facultativa

Figura 5.60. Gel de DGGE (gradiente 20\%-60\%) das variações sazonais na lagoa anaeróbia com primers para as BRS, referente aos horários: T1(a) e T3(b)

Figura 5.61. Gel de DGGE (gradiente 20\%-60\%) das variações sazonais na lagoa facultativa com primers para as BRS, referente aos horários: T1(a) e T3(b)

Figura 5.62. Árvore filogenética de consenso baseada nas seqüências das bandas recortadas do DGGE com primers para as bactérias redutoras de sulfato, obtidas das lagoas anaeróbia e facultativa

Figura 5.63. Frasco contendo crescimento de bactérias em suspensão com inóculo proveniente da lagoa anaeróbia

Figura 5.64. Frascos apresentando crescimento de bactérias fototróficas púrpuras incubadas a $30 \pm 2^{\circ} \mathrm{C}$ e $4000-5000$ lux de intensidade luminosa

Figura 5.65. Diluição seriada em meio líquido de cultura de bactérias fototróficas púrpuras

Figura 5.66. Microscopia de contraste de fase de bacilos curvos semelhantes a bactéria fototrófica púrpura, em etapa de purificação (Obj. 1000X)

Figura 5.67. Colônias de bactérias fototróficas púrpuras

Figura 5.68. Microscopia óptica de luz de bacilos curvos Gram negativos, semelhantes a bactéria fototrófica púrpura (Obj. 1000X) 


\section{LISTA DE TABELAS}

Tabela 3.1: $\quad$ Resultados da identificação com primers para BRS 30

Tabela 4.1. Cronograma das coletas realizadas nas lagoas anaeróbia e facultativa $\quad 37$

$\begin{array}{lll}\text { Tabela 4.2. } & \text { Parâmetros operacionais da lagoa anaeróbia } & 37\end{array}$

Tabela 4.3. Parâmetros operacionais da lagoa facultativa 38

Tabela 4.4. Composição do meio de cultura $\quad 39$

Tabela 4.5. Preparação dos frascos de inoculação 40

Tabela 4.6. Primers filogenéticos para o Domínio Bacteria, bactérias fototróficas 43

Tabela 4.7. Procedimento para o preparo do mix de PCR 43

Tabela 4.8. Condições utilizadas na programação do aparelho para amplificação por $\quad 43$

Tabela 4.9. Condições utilizadas na programação do aparelho para amplificação por 44

Tabela 5.1. Valores do vento em Jacupiranga nas diferentes estações e horários de 48 coleta

Tabela 5.2. Valores dos parâmetros físico-químicos verificados no afluente e 82

Tabela 5.3. Valores dos parâmetros físico-químicos verificados no afluente e 83

Tabela 5.4. Eficiências de redução na lagoa anaeróbia $\quad 83$

Tabela 5.5. Radiação solar nas diferentes épocas do ano na superfície da lagoa 111

Tabela 5.6. Radiação solar nas diferentes épocas do ano na superfície da lagoa 112 facultativa

Tabela 5.7. Valores dos parâmetros físico-químicos verificados no afluente e 118

Tabela 5.8. Valores dos parâmetros físico-químicos verificados no afluente e 118

$\begin{array}{lll}\text { Tabela 5.9. } & \text { Eficiências de redução (\%) na lagoa facultativa } & 119\end{array}$

Tabela 5.10. Informação das seqüências obtidas das bandas recortadas do DGGE com 133

Tabela 5.11. Informação das seqüências obtidas das bandas recortadas do DGGE com 146

Tabela 5.12. Informação das seqüências com primers para as BRS obtidas das bandas 154

Tabela 5.13. Crescimento de bactérias fototróficas púrpuras 158

Tabela 5.14. Caracterização morfológica das colônias no roll-tube 161 


\section{LISTA DE ABREVIATURAS E SIGLAS}

DGGE: eletroforese em gel de gradiente desnaturante

PCR: reação em cadeia da polimerase

NTK: nitrogênio total Kjeldhal

FTD: fósforo total dissolvido

SSV: sólidos suspensos voláteis

DQO: demanda química de oxigênio

pH: potencial higrogeniônico

DBO: demanda bioquímica do oxigênio

SST: sólidos suspensos totais

SS: sólidos suspensos

$\mathrm{N}-\mathrm{NH}_{3}$ : nitrogênio amoniacal

AOV: ácidos orgânicos voláteis

COD: carbono orgânico dissolvido

pufM: centro de reação fotossintético das bactérias fototróficas púrpuras

ETE: Estação de tratamento de esgoto

Af: afluente

Ef: efluente

S: sub-superfície

CI: camada intermediária

AS: interface água-sedimento

p: primavera

v: verão

o: outono

i: inverno

SST:sólidos suspensos totais

TDH: tempo de detenção hidráulica 


\section{LISTA DE SÍMBOLOS}

$\mu \mathrm{Em}^{-2} \mathrm{~s}^{-1}$ : micro Einstein por metro quadrado por segundo

$\mathrm{nm}$ : nanometro

$\mathrm{mg} / \mathrm{L}$ : miligrama por litro

$\mu \mathrm{g} / \mathrm{L}$ : micrograma por litro

mM: miliMolar

L: litro

m: metro

h: hora

s: segundo

d: dia 



\section{SUMÁRIO}

1.

2.

3.

3.1 .

3.2 .

3.3 .

4.

4.1 .

4.1.2.

4.2 .

4.2.1.

4.3 .

4.4 .

4.5 .

4.5.1.

4.5.2.

4.5.3.

4.5.4.

4.5.4.1.

4.5.5.

4.5.6.

4.5.7.

5.

5.1 .

5.1.1.

5.1.1.1.

5.1.1.2.

5.1.2.

5.1.3.

5.1.4.

5.2 .

5.2.1.

5.2.1.1.

5.2.1.2.

5.2.2.

5.2.3.

5.2.4.

5.3.

5.3.1.

5.3.2.

5.4 .

5.4.1.

5.4.2.

5.4.3.

5.5 .

6.

7.

8.
INTRODUÇÃO

OBJETIVOS

REVISÃO BIBLIOGRÁFICA

Lagoas de estabilização

Florescimento de bactérias fototróficas anoxigênicas

Análise da diversidade microbiana

MATERIAL E MÉTODOS

Localização da área de estudo

Descrição das lagoas em estudo

Análises físico-químicas

Ácidos orgânicos voláteis

Exames microscópicos

Purificação celular

Análise da diversidade microbiana

Extração de DNA

Reação em cadeia da polimerase

Eletroforese em gel de agarose

Eletroforese em gel de gradiente desnaturante

Cálculo do coeficiente de similaridade

Clonagem

Identificação

Análise estatística

RESULTADOS E DISCUSSÃO

Lagoa anaeróbia

Variações sazonais do Domínio Bacteria

Amostragem Diurna

Amostragem Noturna

Diversidade das bactérias fototróficas púrpuras

Diversidade das bactérias redutoras de sulfato

Análise Geral dos Parâmetros Físico-químicos

Lagoa facultativa

Diversidade do Domínio Bacteria

Amostragem Diurna

Amostragem Noturna

Diversidade das bactérias fototróficas púrpuras

Diversidade das bactérias redutoras de sulfato

Análise Geral dos Parâmetros Físico-químicos

Variações nictemerais

Lagoa anaeróbia

Lagoa facultativa

Identificação dos microrganismos

Identificação de Bactérias

Identificação de Bactérias Fototróficas Anoxigênicas

Identificação de Bactérias Redutoras de Sulfato

Purificação de Bactéria Fototrófica Púrpura

CONCLUSÕES

RECOMENDAÇÕES

REFERÊNCIAS BIBLIOGRÁFICAS 



\section{INTRODUÇÃO}

O tratamento das águas residuárias em lagoas de estabilização apresenta ação conjunta de diferentes espécies de microrganismos e, portanto, elevada versatilidade metabólica. Por exemplo, bactérias e algas convivem simbioticamente em lagoas facultativas.

Ecossistemas estratificados promovem o estabelecimento de diferentes microhabitats e, assim, favorecem a diversidade metabólica e, conseqüentemente, a distribuição de diferentes populações microbianas. Estabelecidos verticalmente, os gradientes físicos e químicos podem acomodar distintas populações, dependendo de suas fisiologias. Como resultado, é estabelecida uma estrutura complexa, com crescimentos expressivos, por exemplo, de bactérias púrpuras e verdes, visíveis pelos elevados conteúdos de pigmentos intracelulares (bacterioclorofilas e carotenóides), típicos desses microrganismos.

A mais importante propriedade das bactérias fototróficas anoxigênicas é a presença de pigmentos fotossintéticos, visíveis no espectro de absorção da luz, e a presença de um aparato fotossintético que permite a geração de energia dependente de luz. Com exceção de alguns fototróficos da divisão Proteobacteria, que contêm bacterioclorofilas, esses microrganismos são bactérias anaeróbias que realizam fotossíntese anoxigênica na presença de luz. Geralmente, a biossíntese dos pigmentos e a formação do aparato fotossintético são reprimidos pelo oxigênio e regulados pela intensidade de luz.

As bactérias púrpuras não sulfurosas são encontradas comumente em ambientes expostos à luz e ricos em matéria orgânica, tais como os lagos, sedimentos de rios, lagoas de estabilização, wetlands ou campos de arroz. Algumas espécies de bactérias púrpuras não sulfurosas são típicas de ambientes halófilos e superam as bactérias púrpuras sulfurosas quanto à versatilidade de utilização de diferentes substratos orgânicos. Caracterizam-se também pela variedade de mecanismos alternativos de 
transferência de energia, além de apresentarem o metabolismo mais versátil de conversão de energia observado entre as bactérias.

Diversos estudos mostraram a diversidade metabólica desses microrganismos e a habilidade de Rhodopseudonas capsulata crescer utilizando cinco diferentes vias metabólicas, tais como: (1) anaerobiamente, como fotoautotrófica, com uso de hidrogênio e dióxido de carbono; (2) anaerobiamente, como fotoheterotrófica, com diferentes substratos orgânicos; (3) anaerobiamente, no escuro, com açúcares como única fonte de carbono e de energia; (4) aerobiamente, no escuro, como quimioheterotrófica e (5) aerobiamente, no escuro, como quimioautotrófica com hidrogênio como fonte de energia e elétrons.

Devido à ampla diversidade taxonômica desse grupo, observações microscópicas fornecem poucas informações sobre as espécies e gêneros predominantes nas amostras ambientais.

Métodos da Biologia molecular, como a análise dos ácidos nucléicos extraídos da comunidade total do ambiente, permitem a detecção e identificação filogenética da maioria dos organismos, incluindo aqueles não cultivados. A eletroforese em gel de gradiente desnaturante (DGGE) é amplamente utilizada para descrever a diversidade genética dos microrganismos nos diferentes ambientes. Além dessa técnica, é possível realizar a identificação dos microrganismos por meio do seqüenciamento de bandas selecionadas no DGGE. A combinação desses métodos moleculares com aqueles relacionados com a microbiologia tradicional permite uma análise detalhada da diversidade microbiana no sistema.

Nesse sentido, o presente trabalho avaliou a diversidade das bactérias fototróficas anoxigênicas, assim como do Domínio Bacteria e das bactérias redutoras de sulfato existentes nas lagoas de estabilização anaeróbia e facultativa de Cajati - São Paulo, utilizando o DGGE, com primers específicos para os diferentes microrganismos. A identificação foi realizada mediante a técnica do seqüenciamento de fragmentos do gene RNAr 16S e do centro de reação fotossintético das bactérias fototróficas púrpuras. 
As bactérias anoxigênicas freqüentemente apresentam florescimentos em lagoas de estabilização utilizadas no tratamento de esgoto sanitário, e formam uma camada de cor púrpura na sua superfície. Portanto, o estudo das condições que propiciam tais florescimentos, a diversidade microbiana, o potencial de remoção da matéria orgânica e o estabelecimento das relações entre tais conhecimentos, permitem compreender o metabolismo do sistema. 


\section{OBJETIVOS}

Os objetivos gerais do presente trabalho foram os seguintes:

1. Avaliar a diversidade do Domínio Bacteria, do grupo das bactérias fototróficas anoxigênicas e grupo das bactérias redutoras de sulfato nas lagoas anaeróbia e facultativa, em quatro estações do ano, por meio de técnicas moleculares.

2. Comparar a distribuição dos diferentes microrganismos na sub-superfície, camada intermediária e interface água-sedimento nas lagoas de estabilização nas quatro estações do ano.

Os objetivos secundários foram os seguintes:

a. Relacionar a distribuição dos microrganismos com os parâmetros físico-químicos da água das lagoas.

b. Identificar os microrganismos do Domínio Bacteria e das bactérias redutoras de sulfato mediante seqüenciamento parcial do gene RNAr 16S, utilizando primers específicos para ambos os grupos.

c. Identificar as bactérias fototróficas púrpuras das lagoas anaeróbia e facultativa utilizando os primers puf $\mathrm{M}$ referente à sub-unidade $\mathrm{M}$ do centro fotossintético.

d. Purificar e identificar cultura de bactéria fototrófica púrpura não sulfurosa. 


\section{REVISÃO BIBLIOGRÁFICA}

\subsection{Lagoas de estabilização}

Lagoas de estabilização são sistemas de tratamento biológico de água residuária para remoção ou estabilização da matéria orgânica ou inorgânica. Esses sistemas são economicamente viáveis no projeto, construção, manutenção e operação. São comumente empregadas para tratamento de águas residuárias orgânicas, como por exemplo, provenientes de ampla variedade de indústrias, tais como alimentícia, açucareira, celulose e de papel. Águas residuárias provenientes de indústria de amido são extensivamente tratadas em lagoas de estabilização anaeróbias.

Satoh et al. (1976) pesquisaram a função das bactérias fototróficas na purificação de águas poluídas em lagoas de estabilização e isolaram um representante desnitrificante. Os autores avaliaram sua morfologia, fotopigmentos, exigências de fatores de crescimento (niacina 1,0 mg; tiamina-HCl $1,0 \mathrm{mg}$ e biotina $0,04 \mathrm{mg} / \mathrm{L}$ ) e faixa de utilização de substratos orgânicos $(0,2 \%$ de malato, $0,3 \%$ de extrato de levedura). Segundo os autores, o isolado mostrou semelhança com Rhodopseudomonas sphaeroides, e o denominaram $R$. sphaeroides sp. denitrificans. Esse isolado cresceu anaerobiamente no escuro, com nitrato como aceptor final de elétrons. As células isoladas eram Gram negativas, ovóides ou esféricas de $1 \mu \mathrm{m}$ de largura e 1,3 $\mu \mathrm{m}$ de comprimento, divisão por fissão binária e móvel pela presença de um flagelo polar.

Hosetti et al. (1987) avaliaram o funcionamento de três lagoas de estabilização em diferentes profundidades. A pesquisa foi realizada em cisternas de cimento, com profundidades de 1,22 m (lagoa A), 1,83 m (lagoa B) e 2,44 m (lagoa C), e tempo de detenção hidráulica (TDH) de 10 dias. As amostras foram coletadas na superfície e a cada 
0,31 $\mathrm{m}$ de profundidade. Os resultados revelaram distribuição heterogênea dos microrganismos nas diferentes profundidades. As concentrações de DBO e de nutrientes, assim como as quantidades de bactérias foram máximas no fundo e mínimas na superfície das lagoas. Simultaneamente com essas variações observaram aumentos de $\mathrm{pH}$ e OD nas camadas superficiais das lagoas. As atividades da catalase, fosfatase, protease e amilase foram diretamente relacionadas com o crescimento e a atividade bacteriana. Foi verificada baixa atividade enzimática nas camadas superficiais, sendo crescente com a profundidade da lagoa.

Segundo os autores, a concentração de oxigênio dissolvido afluente foi em média de 0,8 $\mathrm{mg} / \mathrm{L}$, enquanto na superfície das lagoas foi de 7,0 mg/L, sugerindo crescimento e atividade das algas na superfície. Em todas as lagoas, a temperatura variou entre $25,6^{\circ} \mathrm{C}$ a $28,2^{\circ} \mathrm{C}$, tendo sido observado decréscimo gradual da temperatura desde a superfície até o fundo da lagoa. $\mathrm{O} \mathrm{pH}$ na superfície foi de 7,0. Elevadas diferenças de $\mathrm{pH}$ foram observadas na lagoa A, quando comparada com as outras lagoas. Elevados valores de $\mathrm{pH}$ foram observados a $0,91 \mathrm{~m}, 1,52 \mathrm{~m}$ e 1,83 m nas lagoas A, B e C, respectivamente. O valor de $\mathrm{pH}$ a 1,83 $\mathrm{m}$ na lagoa $\mathrm{C}$ foi de 8,32 . O incremento de $\mathrm{pH}$ na lagoa $\mathrm{A}$, a $0,91 \mathrm{~m}$, indicou a profundidade da zona eufótica. Essa zona eufótica foi verificada a 1,52 m na lagoa B e a 1,83 m na lagoa $\mathrm{C}$. Os autores verificaram que as reduções de $\mathrm{N}-\mathrm{NH}_{3}$ e $\mathrm{PO}_{4}{ }^{-3}$ foram diferentes nas lagoas. Uma rápida redução de nutrientes foi observada a $0,93 \mathrm{~m}$ na lagoa $A$, a 1,52 m na lagoa $B$ e 1,83 $\mathrm{m}$ na lagoa $\mathrm{C}$.

A DBO na superfície da lagoa A foi de $58,2 \mathrm{mg} / \mathrm{L}, 68,0 \mathrm{mg} / \mathrm{L}$ na lagoa B e 72,2 mg/L na lagoa C. Concentrações elevadas de DBO foram observadas no fundo, quando comparadas com as da superfície. O incremento de crescimento bacteriano foi observado entre $2,14 \mathrm{~m}$ e 2,44 $\mathrm{m}$ de profundidade na lagoa $\mathrm{C}$, similar ao crescimento observado no fundo das lagoas A e B, devido aos elevados valores de catalase, fosfatase, protease e amilase verificados nestas regiões (HOSETTI et al., 1987).

Dentre os organismos que têm importante função nas lagoas de estabilização, encontram-se Chromobacterium, Flavobacterium, Pseudomonas e Alcaligenes (RIVERA et al., 1986). As espécies dos gêneros Chromobacterium e Flavobacterium degradam ampla variedade de compostos orgânicos e inorgânicos nitrogenados. Rivera et al. desenvolveram 
métodos para isolar e identificar bactérias em duas lagoas de estabilização (México) conectadas em série, com profundidades de 1,5 m, cada uma.

Para isolar espécies de Flavobacterium, os autores (RIVERA et al., 1986) utilizaram tubos contendo caldo nutritivo com $10 \%$ de $\mathrm{NaCl}$. Os tubos foram incubados a $20^{\circ} \mathrm{C}$ por 48 h. Posteriormente, os inóculos foram transferidos para placas de Petri contendo ágar sangue, ágar soja e ágar leite, e incubadas a $20^{\circ} \mathrm{C}$ por $48 \mathrm{~h}$. As espécies isoladas foram utilizadas para identificação mediante testes bioquímicos. Para isolamento das espécies de Chromobacterium inocularam placas de Petri contendo ágar leite, ágar caseinato de sódio modificado, e pH final de 6,0. Os isolados foram identificados utilizando testes bioquímicos. Flavobacterium sp. esteve presente em 25\% das amostras coletadas nas lagoas, enquanto que Chromobacterium sp., em 73\%. Análises dos parâmetros físicoquímicos revelaram que o $\mathrm{pH}$ foi constante e ligeiramente básico $(7,2-7,9)$. A temperatura no sistema de lagoas variou desde $14,4^{\circ} \mathrm{C}$ a $18,4^{\circ} \mathrm{C}$. O valor médio da $\mathrm{DBO}_{5}$ efluente foi de $275,0 \mathrm{mg} / \mathrm{L}$, o de sólidos totais foi de $1.530 \mathrm{mg} / \mathrm{L}$, e o de SST de 753,0 mg/L. Elevadas concentrações de matéria orgânica no sistema, assim como outros parâmetros físicoquímicos, favoreceram maior incidência de Chromobacterium.

Fernández et al. (1992) pesquisaram a influência do $\mathrm{pH}$ na remoção de bactérias coliformes fecais, em lagoas de estabilização facultativas de estação de tratamento de água residuária doméstica na Espanha. A temperatura média anual da água na estação oscilou entre $17^{\circ} \mathrm{C}$ a $18^{\circ} \mathrm{C}$ e o pH médio anual foi de 8,0 . O experimento foi realizado em quimiostato a $22^{\circ} \mathrm{C}$, com $\mathrm{pH}$ controlado, em câmara climatizada iluminada, com fotoperiodo de $12 \mathrm{~h}$, com o intuito de simular as condições da estação de tratamento. O quimiostato foi inoculado com $1,4 \times 10^{6}$ de bactérias coliformes fecais/ $100 \mathrm{~mL}$ e $1,1 \times 10^{10} \mathrm{E}$. coli $/ \mathrm{mL}$. Após quatro dias de experimento, o valor do $\mathrm{pH}$ da água inoculada foi de 8,2 . A evolução da concentração de E. coli foi monitorada durante 28 dias, apresentando decréscimo de 78,18\% durante a primeira semana; de 97,36\% na segunda, e de 99,83\% na terceira. O controle (frasco com água destilada estéril inoculado com $1,1 \times 10^{10}$ de $E$. coli/mL), com pH 9,0, apresentou decréscimo de 58,2\% na terceira semana. De acordo com esse estudo, o pH afetou negativamente o metabolismo de bactérias coliformes fecais, mas não pode ser considerado como principal ou único fator responsável pela eliminação dessas bactérias. 
A temperatura e o pH são duas importantes variáveis ambientais que influenciam a atividade e a velocidade de crescimento das algas e das bactérias heterotróficas nas lagoas de estabilização. Como os microrganismos não têm habilidade para regular sua temperatura interna, a temperatura do meio influencia na composição da biomassa, nas necessidades nutricionais, na natureza do metabolismo e na velocidade das reações metabólicas.

A temperatura varia amplamente nas lagoas de estabilização, dependendo da localização geográfica desta e da estação do ano considerada. Por outro lado, o pH do meio influencia o sistema de transporte de íons e a velocidade metabólica. No esgoto doméstico, o pH pode variar desde 6,0 no afluente, até 11,5 nas lagoas de maturação. Em lagoas de estabilização localizadas em climas tropicais e subtropicais, o $\mathrm{pH}$ é dependente da temperatura da água.

Mayo e Noike (1996) avaliaram o efeito da temperatura e do $\mathrm{pH}$ no crescimento de bactérias heterotróficas utilizando cultura mista com Chlorella vulgaris. As temperaturas estudadas foram $10,15,20$ e $30^{\circ} \mathrm{C}$ e os valores de $\mathrm{pH}$ foram controlados de 6,0 a 11,0, utilizando uma série de quimostatos alimentados com glicose, como principal fonte de carbono. O crescimento de bactérias heterotróficas foi verificado em ágar contendo glicose e triptona. Ágar com $\mathrm{pH} \mathrm{7,0} \mathrm{foi} \mathrm{o} \mathrm{mais} \mathrm{adequado} \mathrm{para} \mathrm{crescimento} \mathrm{de} \mathrm{bactérias}$ heterotróficas. Bactérias que cresceram em pH neutro foram mais sensíveis à variação de $\mathrm{pH}$ do que as que cresceram em $\mathrm{pH}$ alcalino. Não foram observadas diferenças significativas no número de células capazes de formar colônias quando incubadas a $20^{\circ} \mathrm{C}$ e $35^{\circ} \mathrm{C}$, mas o tempo de formação das colônias foi superior em $20^{\circ} \mathrm{C}$. Bactérias heterotróficas não foram sensíveis à temperatura na faixa de $10-20^{\circ} \mathrm{C}$, mas a $30^{\circ} \mathrm{C}$ foi observada uma notável competição por glicose entre Chlorella vulgaris e bactérias heterotróficas. Essa competição foi responsável pela baixa densidade bacteriana em $\mathrm{pH}$ neutro.

Em Campina Grande, Brasil, Oliveira et al. (1996) avaliaram o funcionamento de dez lagoas de estabilização em série, em escala piloto, com intuito de determinar os parâmetros de projeto das lagoas. O sistema de lagoas de estabilização consistiu de uma lagoa anaeróbia seguida de lagoa facultativa secundária e oito lagoas de maturação. O sistema de lagoas de estabilização foi monitorado com tempos de detenção hidráulica total de 19 dias e, posteriormente, com 28,5 dias. As temperaturas médias do efluente das lagoas foram de $22^{\circ} \mathrm{C}$ no primeiro experimento, e de $23^{\circ} \mathrm{C}$ no segundo. Em ambos os períodos, os valores de 
pH afluente e efluente da lagoa anaeróbia diminuíram ligeiramente, com aumentos graduais ao longo das outras lagoas, atingindo valores médios no efluente final de 8,4 e 8,6 no primeiro e segundo experimentos, respectivamente. Durante o segundo experimento, a água residuária bruta apresentou maior concentração de matéria orgânica, como mostrado pelos valores médios de $\mathrm{DBO}_{5}$ de 186-240 mg/L. As médias de DQO (502-508 mg/L) e de SS $(283-298 \mathrm{mg} / \mathrm{L})$ foram aproximadamente as mesmas. Essas concentrações foram reduzidas na lagoa anaeróbia em 81,2 e 61,7\% (DBO $), 63,5$ e 53,9\% (DQO), 79,5 e 75,2\% (SS) e 66,2 e 74,0\% (coliformes fecais), no primeiro e segundo experimentos, respectivamente.

Os autores verificaram que, a partir da lagoa facultativa secundária até a sétima lagoa de maturação, as concentrações médias foram reduzidas gradualmente para 7,0 e 12,0 mg/L $\left(\mathrm{DBO}_{5}\right), 73,0$ e 83,0 mg/L (COD), 28,0 e 39,0 mg/L (SS), e 11 e 48\% (coliformes fecais), no primeiro e segundo experimentos, respectivamente. Em todas as remoções obtidas em ambos os experimentos, o efluente da sexta lagoa de maturação do primeiro experimento, e da quinta lagoa de maturação no segundo experimento atingiram o número recomendado de 1.000 coliformes fecais/100 mL para possibilidade de uso do efluente na irrigação (WHO, 1989). No primeiro experimento, o efluente da lagoa facultativa secundária atingiu o valor recomendado pelas normas dos Estados Unidos (CEC, 1991) de DBO filtrada e SS menores que $25,0 \mathrm{mg} / \mathrm{L}$ e $150,0 \mathrm{mg} / \mathrm{L}$, respectivamente, para o despejo de efluentes de lagoas em córregos.

Lai et al. (1997) pesquisaram os fatores que influenciaram a remoção de nitrogênio em oito lagoas de estabilização conectadas em série na Austrália. Nitrogênio total Kjeldahl (NTK), nitrogênio amoniacal, nitrato e nitrito foram monitorados mensalmente durante 11 meses. Foram também monitorados: $\mathrm{pH}$, temperatura, conteúdo de clorofila $a$ e concentração de oxigênio dissolvido. As temperaturas máxima e mínima em janeiro foram de $26^{\circ} \mathrm{C}$ e $13^{\circ} \mathrm{C}$, respectivamente; em julho foram de $14^{\circ} \mathrm{C}$ e $6,0^{\circ} \mathrm{C}$. A precipitação total anual foi de $660 \mathrm{~mm}$. Elevados conteúdos de clorofila $a$ foram registrados de maio até julho, coincidindo com o período em que foi maior o TDH (150-200d). A lagoa 1 mostrouse estritamente anaeróbia em todas as estações e a concentração de oxigênio dissolvido aumentou da lagoa 2 até a lagoa 8. As variações sazonais de oxigênio dissolvido e pH nas lagoas em série mostraram padrão similar ao do conteúdo de clorofila $a$. A água residuária afluente continha $50,0 \mathrm{mg} / \mathrm{L}$ de nitrogênio total, dos quais $70 \%$ eram de nitrogênio 
amoniacal e 30\% de nitrogênio orgânico, além de quantidades traço de nitrato e nitrito. Os valores médios mensais de oxigênio dissolvido e $\mathrm{pH}$ nas lagoas foram os seguintes: 0,30 $\mathrm{mg} / \mathrm{L}$ e 7,30 (lagoa 1); 1,52 mg/L e 7,67 (lagoa 2); 3,15 mg/L e 7,92 (lagoa 3); 4,65 mg/L e 7,93 (lagoa 4); 5,42 mg/L e 8,05 (lagoa 5); 7,19 mg/L e 8,28 (lagoa 6); 7,62 mg/L e 8,32 (lagoa 7) e 6,78 mg/L e 8,20 (lagoa 8).

Os autores (LAI et al., 1997) verificaram que elevada remoção de nitrogênio ocorreu durante maio-junho, coincidindo com elevados níveis de clorofila $a$ e de oxigênio dissolvido. Todavia, a velocidade de remoção de nitrogênio não foi relacionada com a temperatura e nem com o $\mathrm{pH}$. A maior atividade fotossintética resultante do aumento do fitoplâncton produz incremento de oxigênio dissolvido e cria condições ótimas para ocorrer a nitrificação. Nesse processo, a amônia foi oxidada até nitrito e nitrato que, posteriormente, foram reduzidos a nitrogênio molecular. A nitrificação e desnitrificação foram as rotas de remoção do nitrogênio nas lagoas em estudo.

Variações de NTK foram similares às do nitrogênio amoniacal. As variações na concentração de nitrogênio orgânico estiveram relacionadas com o conteúdo de clorofila $a$. Particularmente, baixas concentrações de nitrogênio orgânico verificadas na lagoa 8 , entre setembro e novembro, coincidiram com o período de baixa abundância de fitoplâncton. As diferentes espécies de nitrogênio exibiram marcada variação sazonal no sistema de lagoas. De abril a agosto, quando o tempo de detenção foi elevado, como também o conteúdo de clorofila $a$, as concentrações de nitrogênio amoniacal foram baixas e, simultaneamente, ocorreram aumentos das concentrações de nitrito e nitrato. Por contraste, não foi observada redução de nitrogênio amoniacal entre setembro e dezembro, quando as concentrações de nitrito e nitrato permaneceram baixas nas lagoas. Isso foi particularmente evidente durante setembro e outubro, quando a quantidade de fitoplâncton foi extremamente baixa (LAI et al., 1997).

Estudos realizados na Europa e América permitiram observar que as eficiências de remoções de nutrientes em lagoas de estabilização foram maiores no verão que no inverno. Similarmente, a eficiência de remoção de nitrogênio amoniacal e a velocidade de nitrificação, em particular, foram superiores no verão. Contrariando o que foi anteriormente mencionado, Lai et al. (1997) verificaram que a remoção de nitrogênio foi mais eficiente durante o outono e no começo do inverno, quando comparada com o verão, época em que a 
remoção de nitrogênio foi incompleta. A remoção completa de nitrogênio amoniacal durante os meses frios foi atribuída, principalmente, ao longo TDH que permitiu o incremento na quantidade do fitoplâncton. A amônia é a forma de nitrogênio preferencialmente utilizada pelo fitoplâncton. Assim, a abundância de fitoplâncton contribuiu para a remoção de nitrogênio da água residuária. $\mathrm{O}$ incremento de nitrogênio orgânico nas últimas lagoas coincidiu com o aumento da concentração de clorofila $a$ durante maio e julho, sugerindo que o nitrogênio inorgânico foi convertido em nitrogênio orgânico pelo crescimento do fitoplâncton.

A redução na concentração de nitrogênio amoniacal, acompanhada do incremento de nitrito e nitrato sugeriu que a nitrificação foi o principal mecanismo de oxidação de nitrogênio. Nesse processo, o nitrogênio amoniacal foi oxidado a nitrito, e a nitrato, por bactérias nitrificantes. A forte correlação observada entre a eficiência de oxidação de nitrogênio e o nível de oxigênio dissolvido, suporta a hipótese que o oxigênio é essencial para a nitrificação. Durante o período com elevada quantidade de fitoplâncton, a atividade fotossintética eleva os níveis de oxigênio dissolvido e o $\mathrm{pH}$, pelo alto consumo do dióxido de carbono. Essas condições são ótimas para as bactérias nitrificantes e pode acelerar a velocidade de nitrificação. A volatilização da amônia pode ser outro importante mecanismo na remoção de nitrogênio amoniacal em lagoas de estabilização. $O$ dióxido de carbono consumido pela atividade fotossintética das algas resulta em aumento do $\mathrm{pH}$. O nitrogênio amoniacal, na água, existe em equilíbrio como amônia dissolvida $\left(\mathrm{NH}_{3}\right)$ e íon amônio $\left(\mathrm{NH}_{4}^{+}\right)$; o pH alcalino favorece o equilíbrio para amônia. A volatilização da amônia para a atmosfera depende do coeficiente de transferência de massa, relacionado ao efeito misto da ação do vento e da temperatura (LAI et al., 1997).

A eficiência do tratamento nas lagoas de estabilização é função dos processos químicos e biológicos, como também do transporte hidráulico que ocorre em seu interior. Devido às diferenças de temperatura e/ou salinidade entre as camadas líquidas das lagoas, as mais leves tendem a sobrepor as mais densas, criando condição de estratificação. Quando o vento incide sobre a superfície da água, as camadas superficiais do corpo da água são misturadas devido aos efeitos cisalhantes e de mergulho que o vento exerce sobre o líquido. No transcurso do tempo, as camadas mais densas do líquido e menos turbulentas vão misturando-se com as camadas menos densas (KELLNER, 2000). 
Lagoas de estabilização para tratamento de água residuária enriquecida com lodo ativado foram pesquisadas por Avelar et al. (2001). Foram utilizadas quatro lagoas em escala piloto, alimentadas com água residuária sintética, preparada a partir de solução estoque contendo peptona $(224,0 \mathrm{mg} / \mathrm{L})$, extrato de carne $(154,0 \mathrm{mg} / \mathrm{L})$, uréia $(30,0 \mathrm{mg} / \mathrm{L})$, $\mathrm{NaCl}(7,0 \mathrm{mg} / \mathrm{L}), \mathrm{CaCl}_{2} \cdot 2 \mathrm{H}_{2} \mathrm{O}(4,0 \mathrm{mg} / \mathrm{L}), \mathrm{MgSO}_{4} \cdot 7 \mathrm{H}_{2} \mathrm{O}(2,0 \mathrm{mg} / \mathrm{L}), \mathrm{K}_{2} \mathrm{HPO}_{4}(21,75$ $\mathrm{mg} / \mathrm{L}), \mathrm{KH}_{2} \mathrm{PO}_{4}(8,5 \mathrm{mg} / \mathrm{L}), \mathrm{Na}_{2} \mathrm{HPO}_{4}(33,4 \mathrm{mg} / \mathrm{L})$ e $\mathrm{NH}_{4} \mathrm{Cl}(1,7 \mathrm{mg} / \mathrm{L})$. Cada lagoa foi iluminada com 690 lux de intensidade luminosa durante 12 h/d. Os autores realizaram amostragens do afluente, e do efluente, na superfície, no meio e no fundo das lagoas. Três lagoas foram enriquecidas com 21,0 L de lodo ativado, contendo 8,0 g SSV/L provenientes da estação de tratamento de água residuária municipal. Após o enriquecimento e aclimatação, as velocidades máximas de remoções de DQO foram de 960,0 e 500,0 kg/ha.d nas lagoas alimentadas em série e em paralelo, respectivamente. Esses valores foram superiores aos valores comumente obtidos em estudos clássicos realizados em lagoas de estabilização, sugerindo que o enriquecimento e a aclimatação aumentam a capacidade de remoção de matéria orgânica nas lagoas facultativas.

Após o enriquecimento, a eficiência dessas lagoas submetidas a elevadas taxas de carga orgânica (superior a $2.800 \mathrm{~kg}$ DQO/ha.d) atingiu velocidade máxima de remoção de matéria orgânica de 970,0 kg DQO/ha.d; ou seja, 2 a 10 vezes superior aos valores comumente registrados, sugerindo que o enriquecimento é um método efetivo para a melhoria da eficiência nas lagoas de estabilização (AVELAR et al. 2001).

O tratamento que ocorre nas lagoas de estabilização é resultado das relações simbiônticas entre espécies de bactérias e algas que apresentam padrões ecológicos diferentes, quando submetidos a crescimento em cultura pura. Mudanças periódicas de $\mathrm{pH}$, temperatura e intensidade de luz controlam a abundância e a atividade de grupos específicos de microrganismos presentes nas lagoas facultativas, por exemplo. Nas lagoas, o tempo de detenção e as características da água residuária também influenciam a atividade simbiótica de algas e bactérias. A utilização de luz natural como fonte de energia, implica que o sistema está sujeito a mudanças ambientais que podem definir zonas que operam por ciclos de luz e escuro. A remoção de $\mathrm{CO}_{2}$ pela fotossíntese e o aumento de $\mathrm{CO}_{2}$ durante à noite, quando predomina a respiração, são acompanhadas de mudanças de $\mathrm{pH}$. Aumento de 
pH superior a 11,0 não é comum nas lagoas de estabilização, pelo fato de que os elevados níveis de $\mathrm{pH}$ diminuem, comumente, durante o período da tarde (KAYOMBO et al., 2002).

Kayombo et al. (2002) coletaram dados de lagoas para determinar a influência dos parâmetros físico-químicos, e verificar as velocidades de produção e consumo de oxigênio dissolvido, que são elementos úteis na operação desses ambientes. O sistema de lagoas de estabilização utilizadas para o tratamento de esgoto doméstico consistiu de uma lagoa facultativa primária, duas lagoas facultativas secundárias, em paralelo, e duas lagoas de maturação em série, trabalhando em paralelo com as anteriores. As temperaturas médias mensais variaram entre $23^{\circ} \mathrm{C}$ e $28^{\circ} \mathrm{C}$. A carga superficial na lagoa facultativa foi de 694,0 kg DQO/ha.d (467 kg DBO $5 /$ ha.d). A porcentagem de remoção de matéria orgânica na lagoa facultativa primária foi de 66\%; nas lagoas facultativas secundárias, $68 \%$ e nas lagoas de maturação, $71 \%$.

As variações diárias dos parâmetros físico-químicos determinados na lagoa facultativa primária foram os seguintes: $\mathrm{pH}$ de 6,3 a 8,3; temperatura de 27,5 a $29,8^{\circ} \mathrm{C}$; oxigênio dissolvido de 3,2 a 13,2 mg/L. As variações médias de $\mathrm{pH}$, temperatura e oxigênio dissolvido mostraram diferenças entre os valores médios mínimos e máximos. Os valores obtidos para as variáveis analisadas, em cada lagoa, foram elevados durante o dia e mínimos durante a noite, mostrando a influência da intensidade da energia solar. A intensidade luminosa aumenta exponencialmente durante o dia e é zero durante a noite, com igual distribuição de $12 \mathrm{~h}$ de luz e escuro. Os autores (KAYOMBO et al., 2002) verificaram que os padrões de velocidades de aumento e de diminuição do $\mathrm{pH}$ nas lagoas seguiram o mesmo padrão observado para o oxigênio dissolvido. Observaram, também, direta relação entre o acréscimo de oxigênio dissolvido e o pH durante o dia, provavelmente pelo consumo fotossintético de $\mathrm{CO}_{2}$. As variações de oxigênio dissolvido e de dióxido de carbono dissolvido indicaram a alternância dos processos; ou seja, durante o dia a concentração de oxigênio dissolvido foi elevada e o contrário ocorreu durante a noite.

As variações diárias de $\mathrm{pH}$, temperatura e oxigênio dissolvido, seguiram o padrão do ciclo diurno natural de intensidade de luz solar nas lagoas. Os valores de $\mathrm{pH}$ no sistema de lagoas podem ser utilizados como indicadores do funcionamento da seguinte forma: $\mathrm{pH}$ acima de 8,0 é produzido pela taxa fotossintética que demanda mais $\mathrm{CO}_{2}$ do que as quantidades disponibilizadas pela respiração e decomposição; $\mathrm{pH}$ abaixo de 8,0 indica que 
a ocorrência da fotossíntese é insuficiente para utilizar completamente o $\mathrm{CO}_{2}$ produzido, e mostra presença de elevada concentração de $\mathrm{CO}_{2}$. Em pH acima de 8,0 a concentração de amônia chega a ser elevada, afetando a atividade fotossintética porque é tóxica às algas (KAYOMBO et al., 2002).

Fiorini (2004) avaliou as mudanças temporais que ocorreram na estrutura da comunidade fitoplanctônica, em função das variáveis físico-químicos da lagoa facultativa da ETE de Cajati-SP. As amostras foram coletadas duas vezes por semana, a $30 \mathrm{~cm} \mathrm{a}$ jusante da lagoa facultativa, em junho, julho, setembro e novembro de 2002 e março de 2003. A concentração média de material em suspensão total, em junho e julho, foi de 1,6 $\mathrm{mg} / \mathrm{L}$. Em setembro e novembro foram de $67,3 \mathrm{mg} / \mathrm{L}$ e 9,2 mg/L, respectivamente; e em março, 7,9 mg/L. As temperaturas médias da água em junho, julho e setembro foram de $22^{\circ} \mathrm{C}$. Em novembro e março, $27^{\circ} \mathrm{C}$. A concentração média de oxigênio dissolvido em junho e julho, foi de 9,2 mg/L; e em setembro, 5,58 mg/L. Nos meses de novembro e março as médias foram de $5,12 \mathrm{mg} / \mathrm{L}$ e $4,41 \mathrm{mg} / \mathrm{L}$, respectivamente. O fitoplâncton observado pertencia às classes Chlorophyceae, Cyanophyceae, Bacillariophyceae, Euglenophyceae, Chrysophyceae, Zygnemaphyceae e Dinophyceae.

Granado (2004) pesquisou as variações nictemerais e sazonais na estrutura da comunidade fitoplanctônica de um sistema australiano de lagoas de estabilização, localizado no município de Novo Horizonte (SP), por meio de análises de abundância, biomassa, densidade, riqueza e índices de diversidade, dominância e equidade. As amostragens nictemerais foram realizadas nas lagoas facultativas 1 e 2 e no efluente final, em quatro épocas do ano: outono, inverno, primavera e verão. A temperatura da água, no outono, nos horários da manhã e da madrugada, foram constantes em torno de $25^{\circ} \mathrm{C}$ a $25,5^{\circ} \mathrm{C}$. Maiores valores foram registrados à tarde, variando de $28,9^{\circ} \mathrm{C}$ a $31,1^{\circ} \mathrm{C}$. No inverno, a variação da temperatura foi menor que no outono, variando de $23^{\circ} \mathrm{C}$ (horários da manhã e da madrugada) a $25,4^{\circ} \mathrm{C}$ (horário da tarde). A maior concentração de sólidos suspensos totais foi observada no inverno $(632,0 \mathrm{mg} / \mathrm{L})$ e as maiores concentrações de DBO afluente foram obtidas no outono, variando de $726,0 \mathrm{mg} / \mathrm{L}$ a $1.273 \mathrm{mg} / \mathrm{L}$. Observou, também, organismos pertencentes às classes Chlorophyceae, Cyanophyceae, Euglenophyceae e Bacillariophyceae. 
Rajbhandari e Annachhatre (2004) usaram lagoas de estabilização no tratamento de água residuária contendo elevado conteúdo de carbono orgânico, amido biodegradável particulado e cianeto. Aproximadamente $4.500 \mathrm{~m}^{3} / \mathrm{d}$ de água residuária da indústria de amido $\left(\mathrm{DBO}_{5}\right.$ de $\left.12.776 \mathrm{mg} / \mathrm{L}\right)$ e $500 \mathrm{~m}^{3} / \mathrm{d}$ de água residuária de indústria de glicose $\left(\mathrm{DBO}_{5}\right.$ de $1.046 \mathrm{mg} / \mathrm{L}$ ) foram tratadas nas quatro lagoas anaeróbias dispostas em série. A temperatura ambiente, durante o período de pesquisa, foi de $30-35^{\circ} \mathrm{C}$. $\mathrm{O} \mathrm{pH}$ das lagoas variou entre 4,2 e 7,6 e o oxigênio dissolvido entre 0,3 e 2,7 mg/L. Os autores observaram remoções superiores a 90\% de carbono orgânico dissolvido e sólidos suspensos totais, e $51 \%$ de remoção de cianeto. A biomassa ativa obtida do sedimento da lagoa anaeróbia e da camada líquida exibiram atividade metanogênica específica de 20,7 e 11,3 ml $\mathrm{CH}_{4} /$ g.SSV.d, respectivamente.

Falco (2005) avaliou a dinâmica de algas e bactérias presentes em sistema australiano de lagoas de estabilização na cidade de Novo Horizonte (SP), determinando as densidades desses microrganismos e a taxa de produção fitoplanctônica, e comparando-as com aquelas das condições abióticas, em escalas nictemeral, sazonal e espacial, longitudinal e vertical. Observou também diferenças sazonais na qualidade do efluente final e no desempenho das lagoas. Obteve no efluente final, no outono, DQO de 330,0 mg/L e no inverno, 392,0 mg/L; os sólidos suspensos, no inverno, foram de 210,0 mg/L; a concentração de NTK, no outono, foi de $49,0 \mathrm{mg} / \mathrm{L}$ e, no inverno, de $62,0 \mathrm{mg} / \mathrm{L}$; para o fósforo total, no inverno, obteve 14,0 mg/L. No verão, DQO e sólidos suspensos estiveram abaixo do esperado (15,0 e 47,0 $\mathrm{mg} / \mathrm{L}$, respectivamente). Para a identificação dos grupos de microrganismos específicos, utilizou sondas de oligonucleotídeos de RNAr 16S, marcadas com corante fluorescente (rodamina) para hibridação in situ, para o Domínio Bacteria EUB 338, e para o Domínio Archaea ARC 915.

O fósforo encontra-se presente em esgostos domésticos principalmente como fosfatos, variando de 6,5 a 9,0 mg/L de fósforo total, e 2,0 a 7,0 mg/L de ortofosfato solúvel. $\mathrm{O}$ ortofosfato solúvel é a forma de fósforo mais prontamente assimilável por organismos aquáticos e plantas. A principal forma de remoção de fósforo em lagoas de estabilização é a precipitação de ortofosfato com íons de cálcio formando hidroxiapatita em condições de altos valores de $\mathrm{pH}$. Quantidades apreciáveis de ortofosfato solúvel também são removidas 
através da assimilação pela biomassa de algas existente em lagoas de estabilização (BARBOSA et al. 2000).

\subsection{Florescimentos de bactérias fototróficas anoxigênicas}

As bactérias fototróficas anoxigênicas são divididas em seis famílias, incluídas nas ordens Rhodospirillales e Chlorobiales. As bactérias fototróficas púrpuras são representadas pelas famílias Chromatiaceae, Rhodospirillaceae e Ectothiorhodospiraceae; enquanto as bactérias fototróficas verdes, pelas famílias Chloroflexaceae, Chlorobiaceae e Heliobacteriaceae. Na família Rhodospirillaceae encontram-se distribuídas as bactérias púrpuras não sulfurosas, fototróficas facultativas, que crescem em condições fotoheterotróficas e fotoautotróficas (MADIGAN et al., 2006). As espécies dessa família geralmente são encontradas em concentrações de $10^{5}$ células $/ \mathrm{mL}$ em ambientes com elevadas quantidades de matéria orgânica. Além disso, coexistem com microrganismos anaeróbios heterotróficos no hipolímnio; em lagoas eutróficas ou em estações de tratamento de águas residuárias. Em processos de purificação de água residuária, as bactérias fototróficas vivem em simbiose com outros heterótrofos e fotoautótrofos (NG et al., 1989).

As bactérias fototróficas púrpuras e verdes são encontradas em ampla variedade de habitats aquáticos, inclusive em lagos ricos em sulfeto, lagoas poluídas por esgoto e em águas termais. Nos lagos, esses microrganismos podem apresentar densidades extremamente altas, sob condições ambientais favoráveis que incluem quantidade suficiente de luz na região anaeróbia, além da presença de doadores de elétrons (VARESCHE, 1997).

As bactérias fototróficas correspondem a um grande grupo de microrganismos metabolicamente diversos, agrupados em função da utilização de sulfeto e da pigmentação característica. As bactérias fototróficas têm importante papel no metabolismo anaeróbio da matéria orgânica, como produtores primários (fotoautotróficos) ou como consumidores de compostos orgânicos reduzidos (fotoheterotróficos) (MADIGAN et al., 2006). A água estagnada, exposta à luz solar, favorece a produção de sulfeto pela decomposição da matéria orgânica, promovendo condições para o crescimento de bactérias fototróficas 
anoxigênicas. Em tais ambientes, essas bactérias ocorrem freqüentemente em grande número e são visíveis porque produzem florescimentos de colorações rósea, vermelha, marrom e verde. Em geral, os florescimentos de bactérias fototróficas contêm, na sua maioria, bactérias sulfurosas (HIRAISHI e UEDA, 1995).

Camatta et al. (2002) avaliaram as possíveis causas e conseqüências que a alteração da cor cinza para rósea pode provocar na operação de lagoas de tratamento de esgoto doméstico. A pesquisa foi desenvolvida no sistema da estação de tratamento de esgoto de Flexal, localizada no município de Cariacica, Espírito Santo (Brasil), constituído de uma lagoa anaeróbia seguida de lagoa facultativa. A eficiência de remoção de DBO foi de 84\%, ST de $40 \%$, SST de $98 \%$ e $63 \%$ de DQO. Em meados de junho/2002 apareceu coloração rósea na lagoa facultativa por algumas horas, e, no dia seguinte, a lagoa anaeróbia também apresentou o mesmo florescimento. Esse florescimento voltou a acontecer sempre na lagoa anaeróbia. As características na qual se encontrava a ETE durante o aparecimento da coloração foram sempre semelhantes: elevatória com recalque paralisado (em manutenção), vazão reduzida de esgoto, tempo nublado, temperatura em torno de $19^{\circ} \mathrm{C}$ e $20^{\circ} \mathrm{C}$.

De acordo com os autores (Op. cit.), a lagoa anaeróbia, quando do aparecimento da coloração rósea, apresentava uma concentração de oxigênio dissolvido superior a $6,5 \mathrm{mg}$ $\mathrm{O}_{2} / \mathrm{L}$, fato acompanhado pela presença de algas. No auge da incidência da coloração rósea, a concentração de oxigênio dissolvido foi de $0,0 \mathrm{mg} \mathrm{O}_{2} / \mathrm{L}$. A mudança de coloração na lagoa provocou alteração em sua eficiência de remoção de DBO, que foi reduzida em $40 \%$ quando comparada com as remoções verificadas após o evento, que eram em média de 85\%. A eficiência de remoção de coliformes fecais também foi influenciada, apresentando, em determinado momento, o índice de coliformes em torno de $10^{1} \mathrm{e}$, em outro período, apresentou apenas redução de, no máximo, duas casas decimais. $\mathrm{O}$ pH das lagoas mantevese em torno de 7 a 8 . De acordo com as análises realizadas e comparando com os dados obtidos em literatura, além das análises microscópicas, os pesquisadores afirmaram que o florescimento foi associada às bactérias fototróficas púrpuras.

Sirianuntapiboon e Srikul (2006) avaliaram a redução da intensidade da cor vermelha em lagoa facultativa utilizada no tratamento de água residuária proveniente de indústria de alimentos para peixes. Essa água residuária apresentou elevadas quantidades de matéria orgânica e de compostos nitrogenados. Em condições facultativas, a água residuária 
apresentou cor vermelha, decorrente do crescimento de bactérias fototróficas púrpuras sulfurosas. A qualidade do efluente apresentou menor intensidade de cor, odor e elevada concentração de sólidos suspensos. O aumento da carga orgânica na lagoa de estabilização primária reduziu o número de algas e aumentou o número de bactérias fototróficas púrpuras sulfurosas. A alta concentração de sulfeto de hidrogênio em estações de tratamento de água residuária com alta taxa fotossintética, pode aumentar a morte das algas e o predomínio das bactérias fototróficas púrpuras sulfurosas. O número de bactérias púrpuras sulfurosas na lagoa aumentou ao mesmo tempo em que as concentrações de sulfeto e de ácidos graxos voláteis na água residuária diminuíram. Processos de tratamento físico e químico foram testados para reduzir as substâncias de cor vermelha da água residuária e melhorar a qualidade do efluente.

Sirianuntapiboon e Srikul (2006) verificaram que o efluente da lagoa facultativa, com elevada intensidade de cor vermelha, apresentou $\mathrm{DBO}_{5}$ de $450-500 \mathrm{mg} / \mathrm{L}$ e concentração de sulfeto de 6-7 mg/L. Nesse estudo, os autores identificaram Chromatium sp., bactéria fototrófica púrpura sulfurosa, como sendo responsável pela cor vermelha na lagoa. Essa bactéria produz pigmento vermelho quando exposta à luz, mas também pode crescer no escuro. A intensidade da cor vermelha foi reduzida em $32,5 \pm 1,5$ e $70,8 \pm 2,8 \%$ quando o efluente foi colocado no escuro, em condições estáticas, ou em condições aeróbias com exposição à luz, respectivamente. A concentração de carbono orgânico dissolvido (COD) e o número de células de Chromatium foram rapidamente reduzidos em $78,6 \pm 2,7 \%$ e $92,0 \pm 1,0 \%$, respectivamente, em condições aeróbias e exposição à luz.

Os autores (Op.cit.) concluíram que produção de cor vermelha por Chromatium foi reprimida pela exposição à luz. A intensidade da cor na água residuária diminuiu rapidamente por aeração, que provocou aumento da concentração de oxigênio dissolvido e do número de bactérias aeróbias e diminuição no número de Chromatium. A matéria orgânica na água residuária diminuiu rapidamente com o crescimento de bactérias aeróbias. Nitrato de potássio $\left(\mathrm{KNO}_{3}\right)$ e cloreto férrico $\left(\mathrm{FeCl}_{3}\right)$ também reduziram a intensidade da cor vermelha na água residuária. As remoções máximas de matéria orgânica foram de $82,1 \% \mathrm{e}$ $83,0 \%$ e de cor vermelha, $90,8 \%$ e $85,3 \%$, respectivamente. O nitrato de potássio $\left(\mathrm{KNO}_{3}\right)$ inibiu o crescimento de Chromatium e favoreceu o aparecimento de outras bactérias que utilizam $\mathrm{NO}_{3}{ }^{-}$como aceptor de elétrons. $\mathrm{O}$ cloreto férrico $\left(\mathrm{FeCl}_{3}\right)$ precipitou íons sulfeto da 
água residuária, diminuindo o número de bactérias fototróficas que produziam cor vermelha.

\subsection{Análise da diversidade microbiana}

Para a sistemática microbiana, a reação em cadeia da polimerase (PCR) é o método básico usado para se obter cópias de segmentos de DNA genômico para clonagem e seqüenciamento de genes utilizados na caracterização e identificação de microrganismos. Nos estudos de Genética de populações e Ecologia microbiana, os fragmentos amplificados por PCR geram dados para o estudo da distribuição natural dos microrganismos no ambiente (LANTZ et al., 1996; DIEZ et al., 2001). Metodologias baseadas na análise de fragmentos específicos de $16 \mathrm{~S}$ ou de genes cromossomais que os codificam (RNAr 16S) têm importância fundamental para o estudo da diversidade de microrganismos em amostras ambientais. O RNAr 16S é um importante marcador filogenético por sua distribuição universal, sua conservação estrutural e funcional, sua presença tanto nas regiões conservadas como nas regiões variáveis e hipervariáveis em diferentes porções da molécula, e por seu tamanho que fornece informação sobre a seqüência de bases, suficiente para inferências filogenéticas (MUYZER, 1993).

Com essa técnica de Biologia Molecular é possível pesquisar a diversidade das bactérias fototróficas anoxigênicas. Por meio da análise molecular realizada em microrganismos presentes em amostras naturais, foram identificadas bactérias fototróficas anoxigênicas púrpuras e verdes, com primers do gene RNAr 16S, seguidos do DGGE e seqüenciamento. Adicionalmente, novos métodos têm sido desenvolvidos para identificação das bactérias púrpuras, como por exemplo, a análise de padrões de bandas de RNA de baixa massa molecular (RNA 5S e RNA transportador-RNAt) (ACHENBACH et al., 2001).

Britschgi e Giovannoni (1991) avaliaram a diversidade do bacterioplâncton de um sistema oligotrófico, na zona fótica do mar de Sargasso (USA), com os objetivos de identificar espécies bacterianas conhecidas ou não, e de construção de provas específicas que pudessem ser utilizadas em estudos ecológicos quantitativos. Os autores encontraram elevada diversidade genética na comunidade bacteriana e proporcionaram marcadores 
filogenéticos do RNAr 16S para duas novas linhagens de bactérias. Dentre as espécies identificadas, destacaram-se Caulobacter crescentus, Rhodopseudomonas marina, Agrobacterium tumefaciens, Escherichia coli e Vibrio harveyi.

Muyzer et al. (1993) analisaram a diversidade genética de populações microbianas complexas com PCR-DGGE. Utilizaram microrganismos de duas origens: sedimento marinho e biofilme bacteriano proveniente de reatores de tratamento de águas residuárias. Aplicaram o DGGE para analisar os fragmentos derivados da região variável V3 do RNAr 16S. Esses fragmentos foram obtidos depois da amplificação dos genes do RNAr 16S provenientes do DNA genômico de cultura mista de microrganismos. Os resultados mostraram a presença de dez diferentes fragmentos de RNAr nas comunidades microbianas, de origens diferentes. Em análise subseqüente de hibridação com oligonucleotídeos específicos foram identificados constituintes particulares da população. Esse procedimento permitiu identificar diretamente a presença e a abundância relativa de diferentes espécies, assim como conhecer os perfis qualitativo e quantitativo da população microbiana. Dentre as espécies identificadas destacaram-se: Escherichia coli, Desulfovibrio desulfuricans, Desulfovibrio sapovorans, Microcoleus chthonoplastes e Thiobacillus thioparus.

Murray et al. (1996) avaliaram a diversidade filogenética temporal e espacial do bacterioplâncton de dois estuários na costa central da Califórnia (USA), por comparação do gene RNAr 16S com a técnica de PCR-DGGE. As amostras foram coletadas na superfície da água nos estuários de San Francisco Bay e Tomales Bay. Ambos os estuários apresentaram o mesmo clima, mas eram física e biologicamente diferentes quanto à quantidade de água afluente (elevada em San Francisco Bay), à turbidez (elevada em San Francisco Bay) e à produção primária (baixa em San Francisco Bay). Foram caracterizados oito DNA genômicos, com seqüência conhecida do RNAr $16 \mathrm{~S}$, correspondendo às seguintes espécies: Agrobacterium tumefaciens, Alcaligenes eutrophus, Desulfovibrio desulfuricans, Pseudomonas testosteroni, Chlorobium limicola, Deinococcus radiodurans, Streptomyces coelicolor e Thermotoga maritima. Posteriormente, as culturas bacterianas foram separadas segundo a morfologia, cor, velocidade de crescimento e produção de única banda no PCR-DGGE, com primers GC358F e 517R. Os autores encontraram, em média, 26 e 20 linhagens em cada estuário, respectivamente, e 5 linhagens que eram comuns aos 
mesmos. As semelhanças das amostras coletadas em estações próximas foram superiores, quando comparadas com aquelas de estações distantes, o que sugeriu substituição das linhagens ao longo do perfil vertical da água nos estuários.

Ferris et al. (1996) utilizaram a PCR-DGGE para estudos da diversidade, evolução e ecologia das populações microbianas existentes no Park National Yellowstone (USA). A DGGE permitiu uma rápida avaliação da distribuição das seqüências amplificadas por PCR do RNAr 16S. Foram avaliados padrões de bandas por DGGE e identificadas populações bacterianas por seqüenciamento das bandas individuais. Foram detectadas duas populações de cianobactérias e uma de bactérias verdes não sulfurosas. Também encontraram novas espécies de cianobactérias, bactérias verdes não sulfurosas e bactérias verdes sulfurosas, tais como Synechococcus sp. e Chloroflexus sp.

Casamayor et al. (2000) avaliaram as associações microbianas em dois lagos, Cisó e Vilar (Espanha), por meio de exames microscópicos, PCR-DGGE e análise da seqüência do RNAr 16S. As amostras foram coletadas em duas épocas diferentes do ano (inverno e primavera) e em diferentes profundidades. Embora os lagos apresentassem as mesmas condições climáticas e a mesma fonte de água, os parâmetros limnológicos foram diferentes, assim como as bactérias fotossintéticas identificadas morfologicamente por microscopia. O lago Cisó apresentava uma área superficial de aproximadamente $650 \mathrm{~m}^{2} \mathrm{e}$ profundidade máxima de $6,5 \mathrm{~m}$. Durante o inverno apresentava condições anóxicas, com elevada concentração de sulfeto (acima de 0,5 mM). Sob essas condições, os organismos eucarióticos desapareceram, permanecendo exclusivamente os microrganismos procarióticos, com distribuição de densas populações de bactérias sulfurosas fototróficas no lago. A penetração da luz foi limitada severamente pela abundância destas populações, extinguindo-se a poucos centímetros de profundidade.

O lago Vilar apresentava uma área superficial de aproximadamente $11.000 \mathrm{~m}^{2} \mathrm{e}$ profundidade máxima de 9,0 m. O sulfeto esteve presente durante todo o ano, associado a densas populações de bactérias fototróficas sulfurosas, a 4,5 $\mathrm{m}$ de profundidade. A temperatura da água variou em ambos os lagos na faixa de $8^{\circ} \mathrm{C} \mathrm{a} 15^{\circ} \mathrm{C}$; a penetração da luz foi até 2,0 m no lago Cisó, e 5,0 m no lago Vilar. Elevadas concentrações de sulfeto foram encontradas em ambos os lagos, tendo sido de 0,4 $\mathrm{mM}$ no lago Cisó e 1,0 mM no lago Vilar. As seqüências obtidas das amostras do lago Cisó foram relacionadas às bactérias 
gram-positivas e aos membros da divisão Proteobacteria. As seqüências obtidas no lago Vilar foram relacionadas aos membros do filo Cytophaga-Flavobacterium-Bacteroides e de cianobactérias.

Segundo os autores (CASAMAYOR et al. 2000), as mudanças na composição de espécies foram relevantes do inverno à primavera. Os dados evidenciaram que as seqüências obtidas no DGGE corresponderam aos microrganismos que estiveram presentes em elevadas densidades nos sistemas naturais. No lago Cisó foram encontradas cinco populações bacterianas, tais como bactérias verdes sulfurosas semelhantes a Chlorobium, em concentração de $10^{7}$ células $/ \mathrm{mL}$, e bactérias púrpuras sulfurosas semelhantes a Amoebobacter e Thiocystis, em concentração de $10^{5}$ células $/ \mathrm{mL}$. Outras populações, semelhantes a Chromatium, foram encontradas em concentrações variando entre $10^{3}$ e $10^{4}$ células/mL. No lago Vilar não foram detectadas bactérias púrpuras sulfurosas, e as bactérias verdes sulfurosas presentes foram similares a Chlorobium phaeobacteroides (concentração máxima de $7 \times 10^{6}$ células $/ \mathrm{mL}$ ). A análise filogenética indicou que diferentes bactérias e linhagens de arquéias estiveram presentes. Dentre as arquéias, foram encontradas espécies metanogênicas e termofílicas relacionadas a Euryarchaeota e Crenarchaeota, respectivamente.

Achenbach et al. (2001) utilizaram primers específicos para avaliar, por PCRDGGE, bactérias verdes sulfurosas, bactérias verdes não sulfurosas e Heliobacteria. Além disso, usaram primers específicos fotossintéticos para a detecção de bactérias fototróficas púrpuras, designados como pufM, que codifica a subunidade $\mathrm{M}$ do centro de reação fotossintético, universalmente distribuído entre bactérias fototróficas púrpuras. O primer pufM amplifica o DNA não somente de bactérias fototróficas púrpuras sulfurosas e não sulfurosas, mas também de Chloroflexus sp. (bactéria verde não sulfurosa). Apesar da estrutura do centro de reação da bactéria púrpura ser semelhante ao fotossistema II das plantas verdes, os primers pufM não amplificam o DNA de cianobactérias, o que indica sua especificidade para bactérias fototróficas.

Para verificar a utilidade dos primers puf $\mathrm{M}$, na detecção de diferentes espécies de bactérias fototróficas e de Proteobacteria não fototróficas, Achenbach et al. (2001) prepararam o DGGE dos produtos amplificados com os primers pufM.557F e pufM.750R. Nesse caso, foram utilizadas bactérias fototróficas púrpuras sulfurosas e não sulfurosas 
como controle positivo, assim como bactéria verde não sulfurosa Chloroflexus aurantiacus. As espécies de Proteobacteria não fototróficas apresentaram resultado negativo na amplificação por PCR com o conjunto de primers.

Os mesmos autores anteriormente citados, também realizaram o DGGE de mistura de bactérias púrpuras conhecidas: Thermochromatium tepidum, Rhodopseudomonas palustris e Rhodobacter sphaeroides para testar a utilidade dos primers pufM na detecção de diferentes espécies de bactérias fototróficas púrpuras no ambiente. Os produtos do pufM das três espécies foram identificados facilmente no DGGE. O DNA de cada uma dessas bandas no DGGE foi extraído, seqüenciado e clonado. Os autores verificaram que as seqüências do pufM, provenientes das bandas do DGGE da cultura pura de bactérias fototróficas púrpuras, eram idênticas às seqüências correspondentes às bandas provenientes da amplificação da cultura mista de bactérias fototróficas púrpuras. $\mathrm{O}$ uso dos primers para RNAr 16S e do pufM, em uma mesma amostra, permitiu diferenciar, com maior segurança, as bactérias verdes não sulfurosas das bactérias fototróficas púrpuras. Essa combinação de primers filogenético e fotossintético específico dos grupos de bactérias fototróficas conhecidas constitui, portanto, importante ferramenta molecular para a avaliação rápida de amostras naturais em habitats contendo novas espécies de interesse e de importância ecológica.

A mais importante característica comum entre as bactérias fototróficas anoxigênicas é a presença de pigmentos fotossintéticos visíveis no espectro de absorção da luz, e o aparato fotossintético que utiliza luz para geração de energia (IMHOFF et al., 2004). O complexo centro de reação fotoquímica é uma proteína de membrana, que converte energia luminosa em energia eletroquímica através de processos de transferência de elétrons e bomba de prótons. A estrutura tridimensional do complexo centro de reação foi estudada em duas espécies de bactérias púrpuras distantemente relacionadas, Rhodopseudomonas viridis e Rhodobacter sphaeroides. Os dois complexos mostraram considerável similaridade estrutural, apesar da identidade entre suas seqüências de aminoácidos ser somente de 50-58\% (NAGASHIMA et al., 1997).

O centro de reação fotossintética das bactérias púrpuras está composto de três subunidades: L, M e H. Em Rhodopseudomonas viridis, uma subunidade de citocromo está presente, além das três subunidades. Os genes que codificam para as subunidades L e M 
formam um operon denominado puf $\mathrm{M}$ (Figura 3.1). O puf $\mathrm{M}$ codifica uma proteína do centro de reação fotossintética das bactérias fototróficas púrpuras, assim como de Chloroflexus. Esse gene é parte do operon puf que é um transcrito primário que sofre decréscimo diferencial. Em estudos clássicos de fototróficos anoxigênicos, o operon puf é reprimido pelo oxigênio e fracamente reprimido pela luz, embora em organismos fototróficos anoxigênicos aeróbios, a expressão do operon puf não seja sensível ao oxigênio, mas fortemente reprimida por elevadas intensidades de luz (KARR et al., 2003).

\section{5'-CTGTTCGACTTCTGGGTGGG}

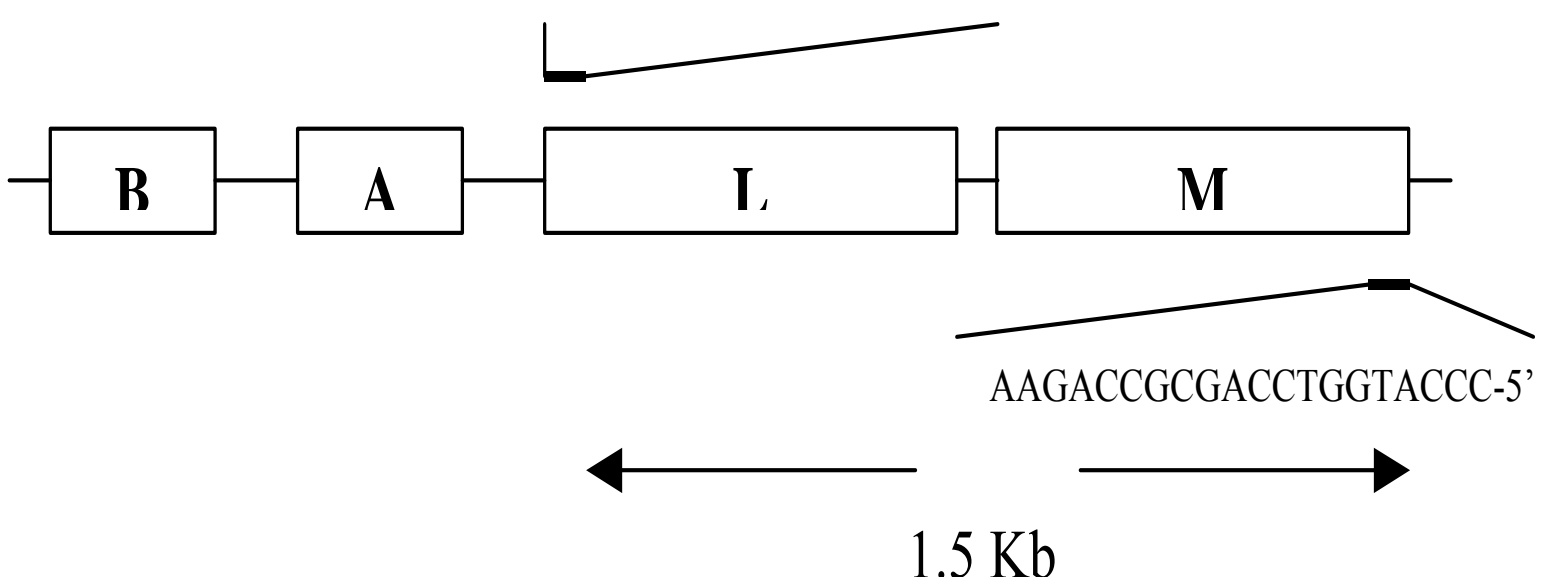

Figura 3.1: Centro de reação fotossintética das bactérias púrpuras (operon puf) Fonte: Nagashima et al. (1997)

Izu et al. (2001) avaliaram, em fotobiorreator, o efeito da aeração no crescimento de bactérias púrpuras não sulfurosas. O volume do fotobiorreator foi de 3,0 L, iluminado com duas lâmpadas de $60 \mathrm{~W}$. Os autores aplicaram aeração contínua de $100 \mathrm{~mL}$ ar/minuto no primeiro ensaio; aeração intermitente de $50 \mathrm{~mL}$.ar/minuto no segundo ensaio, e nitrogênio gasoso a 100 e $80 \mathrm{~mL} /$ minuto no terceiro e quarto ensaios, respectivamente. A intensidade da luz na superfície do reator foi de 5.800 lux, e o $\mathrm{pH}$ foi mantido em 7,5 a $32^{\circ} \mathrm{C}$. $\mathrm{Na}$ amplificação por PCR utilizaram os primers 357FGC/518R. Mudanças nas comunidades bacterianas foram analisadas por DGGE e a hibridização in situ (FISH). As mudanças nas 
bandas padrões no DGGE foram pequenas e foram obtidas poucas bandas predominantes na condição sem aeração. Os resultados do sequenciamento das bandas predominantes no DGGE identificaram Rhodobacter sphaeroides e Rhodopseudomonas palustris. Sob condições de aeração, algumas bandas apareceram, mas não foram dominantes no fotobiorreator, tais como Pseudomonas putida e Acinetobacter haemolyticus.

Mir et al. (2002) avaliaram o ciclo do enxofre em ecossistemas microbianos estratificados (microbial mats) do Delta do Ebro (Espanha). Os autores estudaram a distribuição vertical dos dois maiores grupos funcionais envolvidos no ciclo do enxofre: bactérias fototróficas anoxigênicas e bactérias redutoras de sulfato (BRS).

Os ecossistemas microbianos estratificados (microbial mats) são caracterizados pelas flutuações sazonais e pelas flutuações na concentração de oxigênio e sulfeto. No microbial mats, $99 \%$ da fotoassimilação de $\mathrm{CO}_{2}$, redução de sulfato e oxidação de sulfeto ocorreram acima de 5-10 $\mathrm{mm}$ do sedimento. As fotossínteses anoxigênica e oxigênica têm importante função nos processos de oxidação de sulfeto nesses ambientes. Os microbial mats exibem elevada produtividade primária e rápida reciclagem de matéria orgânica. Nesses ambientes, os processos de mineralização são mediados pelas BRS. A redução de sulfato é um processo chave na geração de compostos reduzidos de enxofre que são utilizados por bactérias quimolitotróficas, bactérias fototróficas anoxigênicas e BRS. Bactérias quimolitotróficas obtêm energia pela oxidação de compostos reduzidos de enxofre, enquanto bactérias fototróficas anoxigênicas utilizam esses compostos como doadores de elétrons para fixar o $\mathrm{CO}_{2}$ em presença de luz. As BRS têm importante papel na regulação do fluxo de elétrons no ciclo do enxofre no microbial mats, pela versatilidade metabólica que apresentam, por poderem reduzir sulfato, sulfito e tiossulfato em sulfeto de hidrogênio, utilizando uma variedade de substratos orgânicos e hidrogênio como doadores de elétrons.

Karr et al. (2003) avaliaram a composição e a atividade de uma comunidade de bactérias fototróficas púrpuras no lago Fryxell (Antártica), utilizando primers específicos do centro fotossintético, denominados pufM. O lago Fryxell é meromítico, com profundidade máxima de $19 \mathrm{~m}$. Apresentou temperatura variando entre $0^{\circ} \mathrm{C}$ a $2,5^{\circ} \mathrm{C}$; oxigênio dissolvido em $0,0 \mathrm{mg} / \mathrm{L}$ a $0,61 \mathrm{mg} / \mathrm{L}$ e sulfeto, em $0,0 \mathrm{mg} / \mathrm{L}$ a $1,1 \mathrm{mg} / \mathrm{L}$ ao longo da coluna da água. Os resultados revelaram elevada diversidade e distribuição estratificada 
de bactérias púrpuras não sulfurosas. Culturas enriquecidas de bactérias púrpuras mostraram duas morfologias, cada uma com puf $\mathrm{M}$ idêntico ao detectado na amostra natural. Os isolados também continham vesículas de gás, estruturas de flotação desconhecidas em bactérias púrpuras não sulfurosas, que podem ser necessárias para que esses microrganismos se distribuam em profundidades específicas na coluna da água. No lago Fryxell, a radiação fotossinteticamente ativa foi reduzida em mais de $90 \%$ a profundidades de 4 a 9 m, e em outros 90\%, de 9 a $11 \mathrm{~m}$ de profundidade. Amplificação e análises de DGGE do gene pufM na coluna d'água no lago Fryxell revelaram a presença de muitas linhagens em todas as profundidades amostradas. As análises das seqüências dessas linhagens produziram 33 clones, que foram distribuídos em seis grupos distintos, representados pelas subdivisões $\alpha$ e $\beta$ Proteobacteria. Muitos dos clones agrupados foram encontrados em profundidades específicas, como resultado dos gradientes físico-químicos de luz e oxigênio existentes no lago.

M'Peko (2003) utilizou o DGGE para avaliar espécies de Microcystis (cianobactérias) na superfície de um sistema de lagoas de estabilização de São Lourenço da Serra (SP). Na amplificação por PCR utilizou primers específicos que amplificam o RNAr 16S, tais como 27F1/1494R, 338FGC/518R, 209F/409R, CYA359F/CYA781R, CYA106F/CYA781R. No perfil de bandas padrões no DGGE obteve 18 bandas predominantes da amostra das lagoas.

Koizumi et al. (2004) pesquisaram mudanças verticais e temporais das comunidades microbianas na coluna d'água e no sedimento de um lago meromítico (Kaiike, Japão), mediante utilização de PCR-DGGE, com primers que amplificam o DNAr $16 \mathrm{~S}$ (EUB338FGC/907R). A temperatura no sedimento foi de $20^{\circ} \mathrm{C}$ e na coluna da água esta variou entre $22^{\circ} \mathrm{C}$ a $34^{\circ} \mathrm{C}$. A concentração de sulfeto no sedimento variou entre 1.000 a $2.000 \mu \mathrm{M}$. A intensidade de luz diminuiu com a profundidade em $0,1-1,8 \mu \mathrm{E} / \mathrm{m}^{2} \mathrm{~s}(0,1$ $0,15 \%$ da intensidade na superfície). Mudanças temporais das comunidades microbianas foram observadas na coluna de água e na interface água-sedimento. Mediante seqüenciamento de 51 bandas recortadas do DGGE, foram identificados os seguintes grupos filogenéticos: Alpha-Proteobacteria, Gamma-Proteobacteria, DeltaProteobacteria, Epsilon-Proteobacteria, Phylum Bacteroidetes, bactéria verde sulfurosa, cianobactérias, espiroquetas, bactérias gram positivas com elevado conteúdo de guanina e 
citosina (G+C), Acidobacterium/Holophaga, Cloroflexi. A comparação das bandas padrões do DGGE de amostras da coluna da água e do sedimento revelou que bactérias específicas acumularam-se na coluna d'água e populações selvagens estavam presentes no sedimento.

Selig et al. (2004) avaliaram perfis verticais de nutrientes solúveis e particulados no final da estratificação de verão nos lagos Tiefer e Dudinghausen, localizados na Alemanha. O lago Tiefer tem área superficial de 15,9 ha e profundidade máxima de 30,6 m. A concentração de fósforo total variou entre 21-97 $\mu \mathrm{g} / \mathrm{L}$ e a de clorofila $a$, entre 2-13 $\mu \mathrm{g} / \mathrm{L}$. O lago Dudinghausen tem área superficial de 18,8 ha e profundidade máxima de 15,2 $\mathrm{m}$. A concentração de fósforo total variou entre $32-80 \mu \mathrm{g} / \mathrm{L}$ e de clorofila $a$, de $2-6 \mu \mathrm{g} / \mathrm{L}$. As concentrações de carbono orgânico particulado e biomassa fitoplanctônica no epilímnio foram maiores no lago Tiefer $(2,58 \mathrm{mg} / \mathrm{L} \mathrm{e} 8,73 \mathrm{mg} / \mathrm{L}$, respectivamente) que no lago Dudinghausen $(0,91 \mathrm{mg} / \mathrm{L}$ e 2,96 mg/L, respectivamente). No lago Dudinghausen, bactérias fototróficas sulfurosas acumularam-se no hipolímnio, entre 8 e $10 \mathrm{~m}$ de profundidade. No lago Tiefer, a baixa penetração de luz (1\% da radiação fotossinteticamente ativa foi verificada até $5,2 \mathrm{~m}$ de profundidade) não favoreceu o desenvolvimento de bactérias fototróficas. Apesar dos dois lagos apresentarem hipolímnio anóxico, os autores assumiram que em ambos o fósforo foi liberado do sedimento para o hipolímnio.

Os autores (Op. cit.) verificaram, também, que no lago Tiefer, o potencial redox (variando entre $-200 \mathrm{mV}$ a $100 \mathrm{mV}$ ), nitrato (entre 0,0 e $0,02 \mathrm{mg} / \mathrm{L}$ ) e nitrito (entre 0,0 e 0,1 $\mathrm{mg} / \mathrm{L}$ ) limitaram a liberação de fósforo. No lago Dudinghausen, parte do fósforo soluvél liberado foi incorporado na biomassa das bactérias fototróficas sulfurosas, transformandose em fósforo particulado. Assim, 70\% do fósforo particulado presente no hipolímnio foram encontrados na camada das bactérias fototróficas sulfurosas, sendo que 15-20\% do fósforo particulado constituiam o polifosfato de reserva. A baixa solubilidade do fósforo reativo para fósforo particulado no hipolímnio foi atribuída a bactérias fototróficas sulfurosas. As bactérias fototróficas sulfurosas atuam como filtro de nutrientes e convertem o fósforo solúvel em fósforo particulado.

Populações de BRS no lago Fryxell foram pesquisadas por Karr et al. (2005), em amostras de água e do sedimento. No lago Fryxell a temperatura variou entre $0^{\circ} \mathrm{C}$ e $2^{\circ} \mathrm{C}$; sulfeto de $0,0 \mathrm{mM}$ a 1,4 $\mathrm{mM}$; sulfato de $0,1 \mathrm{mM}$ a 1,7 mM; oxigênio dissolvido de 0,0 $\mathrm{mM}$ a 0,6 mM e carbono orgânico dissolvido de $0,2 \mathrm{mM}$ a 2,0 mM. Os autores utilizaram 
primers do gene RNAr $16 \mathrm{~S}$ e primers metabólicos do gene $d s r A$, da subunidade $\alpha$, da sulfeto redutase. Culturas enriquecidas de BRS provenientes do lago Fryxell, estabelecidas a $4^{\circ} \mathrm{C}$, mostraram que grupos diversos dessas bactérias estiveram presentes. Dados das seqüências foram comparados com os perfis geoquímicos do lago Fryxell, para identificar possíveis conexões entre a diversidade de BRS e as condições limnológicas.

Muitos grupos de clones foram localizados a profundidades específicas, e conseqüentemente, sob condições físico-químicas específicas. Karr et al. (2005) extraíram DNA genômico de amostras coletadas em diferentes profundidades (8, 9, 11, 14 e $17 \mathrm{~m})$, assim como no sedimento, e estes foram submetidos à amplificação por PCR com primers específicos para BRS do gene RNAr 16S. As mesmas amostras foram amplificadas utilizando os mesmos primers $1 \mathrm{~F} / 4 \mathrm{R}$. No DGGE utilizaram produtos de PCR amplificados com primers $1 \mathrm{~F}$ e $5 \mathrm{R}$. Análises do DGGE revelaram a presença de múltiplas linhagens em cada profundidade do lago. As bandas do DGGE foram recortadas e seqüenciadas, e análise destas revelaram sete grupos de clones (grupos A até G). A Tabela 3.1 mostra os resultados da identificação dos diferentes grupos de clones.

Tabela 3.1: Resultados da identificação com primers para BRS

\begin{tabular}{c|cl}
\hline Grupos & Similaridade \% & \multicolumn{1}{c}{ Microrganismos } \\
\hline A & $84,6-89,0$ & Desulfovibrio \\
B & 74,5 & $\begin{array}{l}\text { Desulfomusa hansenii } \\
\text { C }\end{array}$ \\
& $66,1-73,8$ & $\begin{array}{l}\text { Desulfococcus-Desulfonema- } \\
\text { Desulfosarcina }\end{array}$ \\
D & $75,2-77,1$ & Desulfosarcina variabilis \\
E & $67,6-69,7$ & Desulfobulbus rhabdoformis \\
F & $63,1-63,9$ & Thermodesulforhabdus \\
& & norvegica \\
G & 61,2 & Desulfotomaculum putei \\
\hline
\end{tabular}

Fonte: Karr et al. (2005)

Neste trabalho, os autores (Op. cit.) realizaram análises filogenéticas, as quais indicaram quatro grupos de BRS que estiveram presentes no lago Fryxell (Desulfovibrio, Desulfosarcina, Desulfotomaculum, Desulfobulbus, Desulfobacter e Desulfobacterium). As seqüências do $d s r A$ estiveram presentes em todas as profundidades amostradas e muitos grupos de clones agrupados estiveram localizados em profundidades específicas. Neste lago, a máxima concentração de sulfato foi de $1,72 \mathrm{mM}$ verificada a 13 metros. $\mathrm{O}$ 
decréscimo de sulfato foi observado a partir de $1,17 \mathrm{mM}$ em 17 metros até $0,34 \mathrm{mM}$ em 17,5 metros. Culturas enriquecidas de bactérias púrpuras no lago Fryxell apresentaram crescimento somente de bactérias púrpuras não sulfurosas. Alguns organismos obtidos em cultura pura mostraram extrema tolerância a sulfeto e apresentaram vesículas de gás.

A avaliação da diversidade de bactérias fototróficas anoxigênicas sulfurosas presentes em ecossistemas microbianos estratificados (microbial mats) localizados no Delta Ebro (Espanha) foram realizados por Martínez-Alonso et al. (2005). Os microrganismos presentes nesse local tinham sido estudados por outros pesquisadores, utilizando métodos clássicos de microbiologia. Esses microbial mats eram constituídos por pigmentos (marrom, verde, púrpura) distribuídos em camadas, com predomínio de organismos fototróficos.

Martínez-Alonso et al. (Op. cit.) utilizaram primers específicos que amplificam seqüências do gene RNAr 16S para esse grupo de bactérias. Os produtos da amplificação foram separados por DGGE e as bandas recortadas foram seqüenciadas. As seqüências obtidas foram relacionadas a membros das famílias Chromatiaceae e Ectothiorhodospiraceae.

Devido à ausência de trabalhos de avaliação sobre a diversidade e a identificação dos diferentes microrganismos presentes nas lagoas de estabilização de Cajati (São Paulo), foi importante o desenvolvimento da presente pesquisa, uma vez que esta permitiu conhecer essa diversidade e os principais grupos filogenéticos, mostrando a eficiência dos primers específicos utilizados para os diferentes grupos em estudo.

Neste trabalho avaliou-se a diversidade do Domínio Bacteria, das bactérias fototróficas anoxigênicas púrpuras e das bactérias redutoras de sulfato, nas diferentes épocas do ano e nos diferentes pontos de amostragem, nas lagoas de estabilização facultativa e anaeróbia de Cajati (São Paulo), com o intuito de relacioná-a com os parâmetros físico-químicos e, conseqüentemente, entendê-la melhor, bem como a distribuição dos microrganismos nestes sistemas. 


\section{MATERIAL E MÉTODOS}

As amostras para análise da diversidade microbiana e dos parâmetros físicoquímicos foram coletadas nas Lagoas de Estabilização (facultativa e anaeróbia) de Cajati, no Vale do Ribeira (Estado de São Paulo).

A Figura 4.1 mostra o fluxograma experimental das coletas realizadas durante os anos de 2004 e 2005. A avaliação da diversidade microbiana foi realizada mediante DGGE, utilizando-se primers que amplificam o gene RNAr 16S referente ao Domínio Bacteria e grupo das BRS. Para o grupo das bactérias fototróficas púrpuras foram utilizados primers puf $\mathrm{M}$, específicos para o centro de reação fotossintético. A identificação dos microrganismos foi efetuada realizando-se a clonagem para a amostra da purificação celular, ou recortando as bandas do DGGE e re-amplificando-as com os mesmos primers mencionados acima.

Nos mesmos pontos de amostragem foram coletadas amostras de água para determinação da demanda química de oxigênio (DQO), e das concentrações de sulfato, sólidos suspensos voláteis (SSV), ácidos orgânicos voláteis e nutrientes totais e dissolvidos. Após as coletas, as amostras acondicionadas foram transferidas para temperaturas de $-20^{\circ} \mathrm{C}$ e $4^{\circ} \mathrm{C}$, para avaliação da diversidade e análises dos parâmetros físico-químicos, respectivamente. Em cada ponto de amostragem foram realizadas leituras de concentração de oxigênio dissolvido, $\mathrm{pH}$ e temperatura utilizando uma multisonda, e radiação solar fotossinteticamente ativa incidente utilizando um radiômetro.

Também foram coletados amostras para o enriquecimento e purificação da cultura de bactérias púrpuras não sulfurosas. Para tanto, foi utilizado meio de cultura específico, sob anaerobiose. 


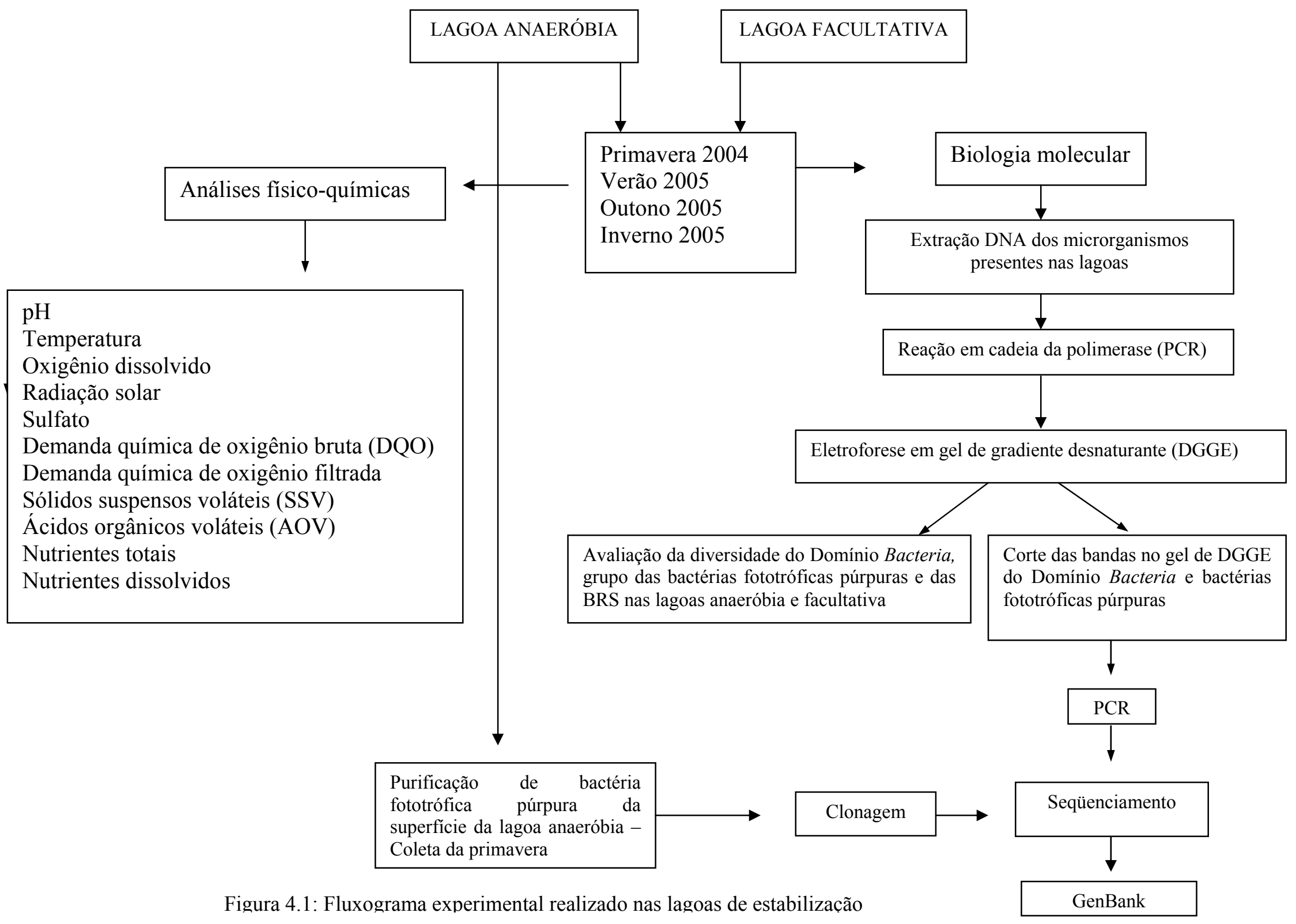




\subsection{Localização da área de estudo}

No ecossistema de estudo foi escolhida a microbacia de Cajati, na região do Baixo Ribeira de Iguape. Essa seleção deveu-se à presença dos sistemas de tratamento de esgotos sanitários utilizados pelos municípios; ou seja, lagoas de estabilização.

A Bacia do Baixo Ribeira de Iguape está localizada entre as latitudes $23^{\circ} 30^{\prime}$ e $25^{\circ} 30^{\prime} \mathrm{S}$ e as longitudes $46^{\circ} 50^{\prime}$ e $50^{\circ} 00^{\prime} \mathrm{W}$, compreendendo uma área de $24.980 \mathrm{~km}^{2}$, da qual 61\% pertencem ao Estado de São Paulo e 39\%, ao Estado do Paraná, constituindo as regiões de menor desenvolvimento econômico dos dois estados (CALIJURI et al., 2002).

O município de Cajati, situado no Estado de São Paulo, possui uma área de 454.92

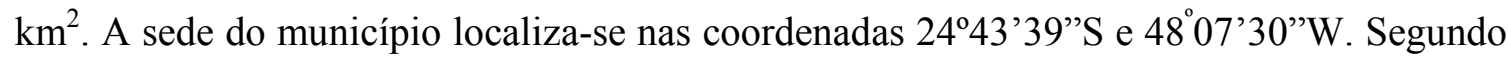
o último censo, sua população está em torno de 29.227 habitantes, com 71,84\% desse total concentrados na área urbana (IBGE, 2003).

O presente trabalho de pesquisa foi inserido no Projeto Temático: "Estudo dos sistemas redutores de cargas naturais e artificiais para a sustentabilidade dos Recursos Hídricos do Baixo Ribeira de Iguape - SP", sob coordenação da Prof ${ }^{\mathrm{a}}$. Tit. Maria do Carmo Calijuri, cujo principal objetivo é o estudo da dinâmica de sistemas redutores de cargas poluidoras, nas microbacias dos rios Jacupiranga e Pariquera-açu.

\subsubsection{Descrição das lagoas em estudo}

A Estação de Tratamento de Esgoto sanitário (ETE) do município de Cajati é constituída por uma caixa de areia com calha Parshall, seguida de uma lagoa anaeróbia e uma lagoa facultativa, em série, e caixa de cloração, com vazão afluente de 41,64 L/s. O efluente da estação é lançado no Rio Jacupiranguinha.

Foram realizadas quatro coletas durante os anos de 2004 e 2005, com amostragem na caixa de entrada da lagoa anaeróbia (afluente), e nas seguintes profundidades: subsuperfície (S), camada intermediária (CI) e interface água-sedimento (AS), em ponto específico da lagoa (a 54,0 m e 28,0 m das margens) e, finalmente, na saída (efluente). Amostragem semelhante foi realizada na lagoa facultativa (a 90,0 m e 71,0 $\mathrm{m}$ das margens). As amostragens da camada intermediária e da interface água-sedimento na lagoa anaeróbia 
foram realizadas a 1,50 $\mathrm{m}$ e 3,00 $\mathrm{m}$ de profundidade respectivamente; e na lagoa facultativa foram a $0,70 \mathrm{~m}$ e $1,20 \mathrm{~m}$ desde a superfície (Figura 4.2). Os pontos específicos de coleta nas lagoas apresentaram circulação e mistura devido à ação do vento nos horários das coletas realizadas nas diferentes épocas do ano.

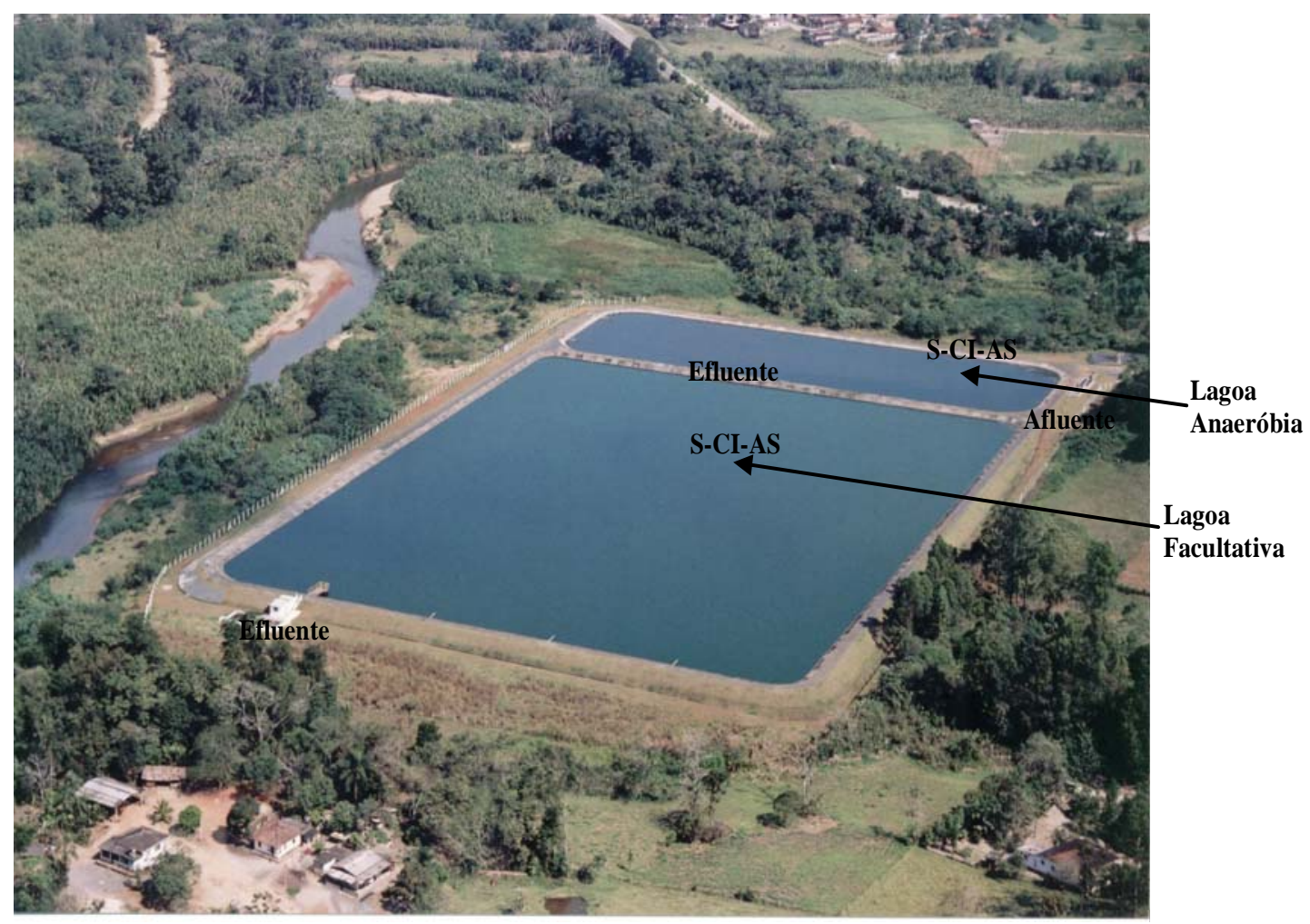

Figura 4.2: Lagoas de estabilização anaeróbia e facultativa de Cajati

As coletas foram realizadas durante as quatro épocas do ano (primavera, verão, outono e inverno), com variação nictemeral (de 6 em 6 h). As amostras foram coletadas com amostrador Van Dorn, transferidas para frascos apropriados e submetidas à temperatura de $4^{\circ} \mathrm{C}$. Posteriormente, as amostras, foram analisadas no Laboratório de Processos Biológicos (LPB-EESC-USP) (Tabela 4.1). 
Tabela 4.1: Cronograma das coletas realizadas nas lagoas anaeróbia e facultativa

\begin{tabular}{l|cc}
\hline \multicolumn{1}{c|}{ Coletas } & \multicolumn{2}{|c}{ Horários } \\
\hline Primavera (Outubro de 2004) & T0 & $08: 00 \mathrm{~h}$ \\
& T2 & $18: 00 \mathrm{~h}$ \\
& T3 & $02: 00 \mathrm{~h}$ \\
Verão (Janeiro de 2005) & T4 & $08: 00 \mathrm{~h}$ \\
& T0 & $08: 00 \mathrm{~h}$ \\
& T1 & $14: 00 \mathrm{~h}$ \\
& T2 & $20: 00 \mathrm{~h}$ \\
& T3 & $02: 00 \mathrm{~h}$ \\
Outono (Abril de 2005) & T4 & $08: 00 \mathrm{~h}$ \\
& & \\
& T0 & $08: 00 \mathrm{~h}$ \\
Inverno (Julho de 2005) & T1 & $14: 00 \mathrm{~h}$ \\
& T2 & $20: 00 \mathrm{~h}$ \\
& T3 & $02: 00 \mathrm{~h}$ \\
& T4 & $08: 00 \mathrm{~h}$ \\
& & \\
& T0 & $08: 00 \mathrm{~h}$ \\
& T1 & $14: 00 \mathrm{~h}$ \\
& T2 & $20: 00 \mathrm{~h}$ \\
& T3 & $02: 00 \mathrm{~h}$ \\
& T4 & $08: 00 \mathrm{~h}$ \\
\hline
\end{tabular}

Os parâmetros morfométricos e operacionais das lagoas anaeróbia e facultativa estão apresentados nas Tabelas 4.2 e 4.3 .

Tabela 4.2: Parâmetros operacionais da lagoa anaeróbia

\begin{tabular}{l|c}
\hline \multicolumn{1}{c|}{ Parâmetros } & Valor \\
\hline Comprimento $(\mathrm{m})$ & 160,5 \\
Largura $(\mathrm{m})$ & 53,0 \\
Profundidade $(\mathrm{m})$ & 4,0 \\
Área $\left(\mathrm{m}^{2}\right)$ & 6.472 \\
Altura da lâmina d'água $(\mathrm{m})$ & 4,0 \\
Volume útil $\left(\mathrm{m}^{3}\right)$ & $25.886,00$ \\
Carga orgânica média afluente $(\mathrm{kg} \mathrm{DBO} / \mathrm{d})$ & $5.177,20$ \\
DBO de projeto $(\mathrm{mg} / \mathrm{L})$ & 300,00 \\
Vazão média afluente prevista para final de projeto $\left(\mathrm{m}^{3} / \mathrm{d}\right)$ & $17.257,33$ \\
Capacidade de tratamento instalada $\left(\mathrm{m}^{3} / \mathrm{d}\right)$ & $17.257,33$ \\
Vazão de projeto $\left(\mathrm{m}^{3} / \mathrm{d}\right)$ & $4.681,15$ \\
Vazão tratada $\left(\mathrm{m}^{3} / \mathrm{d}\right)$ & $1.017,79$ \\
TDH (dias) & 25,0 \\
\hline
\end{tabular}

Fonte: Superintendência de gestão e desenvolvimento operacional de sistemas regionais Sabesp Registro (setembro/2004) 
Tabela 4.3: Parâmetros operacionais da lagoa facultativa

\begin{tabular}{l|c}
\hline \multicolumn{1}{c|}{ Parâmetros } & Valor \\
\hline Comprimento $(\mathrm{m})$ & 214,0 \\
Largura $(\mathrm{m})$ & 163,0 \\
Profundidade $(\mathrm{m})$ & 1,5 \\
Área $\left(\mathrm{m}^{2}\right)$ & $33.600,0$ \\
Volume útil $\left(\mathrm{m}^{3}\right)$ & $50.400,0$ \\
Carga orgânica média afluente $(\mathrm{kg} \mathrm{DBO} / \mathrm{d})$ & 1126,1 \\
Vazão de projeto $\left(\mathrm{m}^{3} / \mathrm{d}\right)$ & 1767,8 \\
TDH (d) & 28,5 \\
\hline
\end{tabular}

Fonte: Superintendência de gestão e desenvolvimento operacional de sistemas regionais Sabesp Registro (setembro/2004)

\subsection{Análises físico-químicas}

As determinações da demanda química de oxigênio (DQO) e das concentrações de sulfato, sólidos suspensos voláteis e nutrientes totais e dissolvidos foram realizadas segundo APHA (1998). As análises de oxigênio dissolvido, $\mathrm{pH}$ e temperatura foram realizadas in situ com eletrodo de membrana, (Yellow Springer, 556 MPS). A radiação solar fotossinteticamente ativa incidente $\left(\mu \mathrm{E} \cdot \mathrm{m}^{-2} \cdot \mathrm{s}^{-1}\right)$ foi determinada in situ com radiômetro (Quanta-Meter Ly-Cor) com 400-700 nm de sensibilidade. As amostras para análises de sólidos suspensos voláteis, DQO filtrada $\left(\mathrm{DQO}_{\mathrm{f}}\right)$ e sulfato foram filtradas em membranas de fibra de vidro com diâmetro de poro de $0,45 \mu \mathrm{m}$.

\subsection{1. Ácidos orgânicos voláteis}

Os ácidos orgânicos voláteis foram determinados por cromatografia gasosa (MORAES et al., 2000). As amostras foram fixadas com 1,0 mL de solução $1 \mathrm{~N}$ de hidróxido de sódio $(\mathrm{NaOH})$, imediatamente após a coleta e submetidas a temperatura de $20^{\circ} \mathrm{C}$ (Anexo A1). 


\subsection{Exames microscópicos}

Todas as amostras foram examinadas através de microscopia óptica comum e contraste de fase, utilizando-se Microscópio Leyca BX60, acoplado à câmara com captura de imagem e software Image-Pro plus. A coloração de Gram foi realizada segundo metodologia descrita por DSM (1991).

\subsection{Purificação celular}

Foram utilizadas amostras das lagoas anaeróbia e facultativa. Para purificação da cultura de bactéria púrpura não sulfurosa foi utilizado meio de cultura seletivo ATCC 112 (VAN NIEL'S, 1944) utilizando-se, como fonte de carbono, acetato de amônia (770,8 mg/L). A Tabela 4.4 descreve a composição do meio de cultura. O procedimento utilizado para o preparo do meio de cultura está descrito a seguir:

a. Ferver água ultrapurificada durante 15 minutos;

b. Resfriar até aproximadamente $60^{\circ} \mathrm{C}$ e então deixar sob fluxo de $\mathrm{N}_{2}(100 \%)$ até atingir temperatura de $\pm 40^{\circ} \mathrm{C}$;

c. Transferir aproximadamente $50 \mathrm{~mL}$ de água para frascos apropriados contendo os reagentes já pesados;

d. Transferir o meio para erlenmeyer e ajustar o pH até 7,0-7,2 com $\mathrm{HCl} 30 \%$; completar o volume para $1.000 \mathrm{~mL}$ e fluxionar $\mathrm{N}_{2}$ (100\%) durante 15 minutos;

e. Distribuir o meio de cultura em frascos apropriados, autoclavar a $121^{\circ} \mathrm{C}$ e $1 \mathrm{~atm}$ por 20 minutos;

f. Após resfriamento, adicionar $770,8 \mathrm{mg} / \mathrm{L}$ de acetato de amônia e $10 \%$ de inóculo da lagoa.

Tabela 4.4: Composição do meio de cultura

\begin{tabular}{l|c}
\hline \multicolumn{1}{c|}{ Reagentes } & Quantidades \\
\hline $\mathrm{K}_{2} \mathrm{HPO}_{4}$ & $1,0 \mathrm{~g}$ \\
$\mathrm{MgSO}_{4} .7 \mathrm{H}_{2} \mathrm{O}$ & $0,5 \mathrm{~g}$ \\
Extrato de levedura & $10,0 \mathrm{~g}$ \\
Água ultrapurificada (q.s.p.) & $1.000,0 \mathrm{~mL}$ \\
\hline
\end{tabular}


A Tabela 4.5 descreve o procedimento de preparação dos frascos de inoculação.

Tabela 4.5: Preparação dos frascos de inoculação

\begin{tabular}{l|c}
\hline \multicolumn{1}{c|}{ Componentes } & Quantidades (mL) \\
\hline Volume de meio & 445,0 \\
Acetato de amônia (770,8 mg/L) & 5,0 \\
Inóculo (10\%) & 50,0 \\
Headspace (50\%) & 500,0 \\
Volume total & $1.000,0$ \\
\hline
\end{tabular}

Foram inoculadas as amostras provenientes das diferentes profundidades das lagoas anaeróbia e facultativa. Os frascos de cultura foram incubados à temperatura de $30 \pm 1^{\circ} \mathrm{C} \mathrm{e}$ intensidade luminosa total de 4.000-5.000 lux, fornecida por duas lâmpadas fluorescentes. Após turvação da cultura, realizou-se o repique em frascos de antibiótico de $30 \mathrm{~mL}$ de volume total, em meio contendo $1.541,6 \mathrm{mg} / \mathrm{L}$ de acetato de amônia. Nos frascos que apresentaram crescimento das bactérias fototróficas púrpuras, procedeu-se novo repique, nas mesmas condições descritas anteriormente. $\mathrm{O}$ isolamento foi realizado com diluições seriais, em meio líquido e, posteriormente, em roll-tube (VARESCHE, 1997). O roll-tube foi realizado com meio de cultura líquido da ATCC 112 (VAN NIEL'S, 1944) acrescido de $2 \%$ de ágar.

A Figura 4.3 apresenta-se o procedimento realizado na purificação da bactéria fototrófica púrpura. 


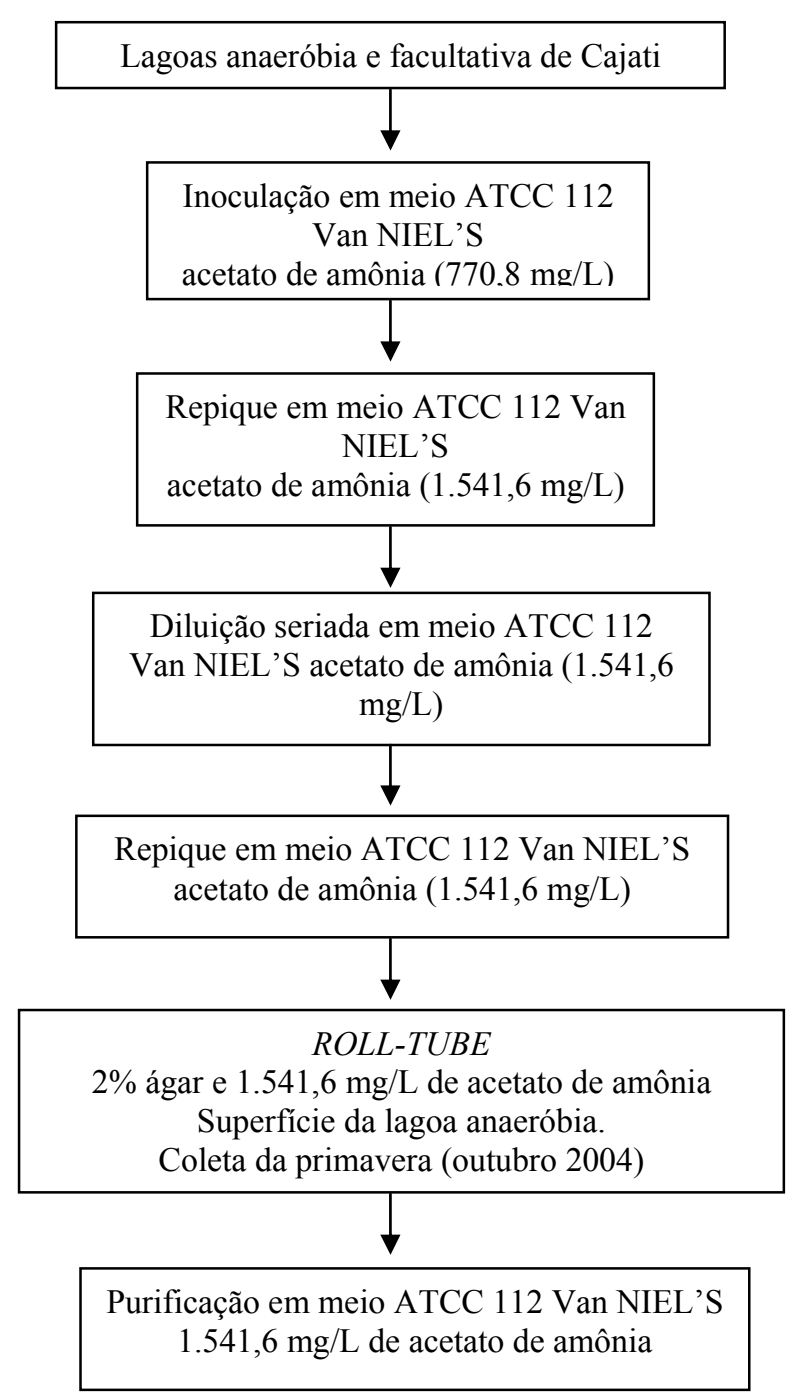

Figura 4.3: Fluxograma da purificação de bactérias fototróficas púrpuras das amostras provenientes das lagoas anaeróbia e facultativa 


\subsection{Análise da diversidade microbiana}

\subsubsection{Extração de DNA}

Foram realizadas as extrações do DNA em todas as amostras coletadas nas lagoas anaeróbia e facultativa, com a finalidade de avaliar a diversidade microbiana. No entanto, para essa avaliação, foram considerados somente os horários de coletas T1 (14:00 h) e T3 $(02: 00 \mathrm{~h})$ porque, em análises preliminares, não foram observadas mudanças nas populações microbianas no DGGE num intervalo curto de tempo (6 horas). Portanto, optouse por avaliar as variações nos períodos diurno e noturno.

Após a coleta, foram centrifugados $200 \mathrm{~mL}$ das amostras provenientes dos diferentes pontos de amostragem, a $6.000 \mathrm{rpm}$, a $4^{\circ} \mathrm{C}$ por 10 minutos. $\mathrm{O}$ pellet obtido foi lavado com 5,0 mL de tampão PBS (137,0 mM de $\mathrm{NaCl} ; 2,6 \mathrm{mM}$ de $\mathrm{KCl} ; 1,7 \mathrm{mM}$ de $\left.\mathrm{KH}_{2} \mathrm{PO}_{4} ; \mathrm{pH} 7,4\right)$. Posteriormente, foi realizada a extração do ácido nucléico de acordo com o protocolo de Griffiths et al. (2000), utilizando glass beads, fenol e clorofórmio (Anexo A2).

\subsubsection{Reação em cadeia da polimerase}

A partir do DNA extraído das amostras, foram obtidos fragmentos do gene do RNAr 16S utilizando-se primers para o Domínio Bacteria, para as BRS, e fragmentos do centro fotossintético do grupo das bactérias fototróficas (Tabela 4.6). Para primers filogenéticos do Domínio Bacteria, foram utilizadas as condições de amplificação descritas por Nielsen et al. (1999). Para primers do grupo das BRS, foram utilizadas as condições de amplificação descritas por Nakagawa et al. (2002). Para amplificação do DNA do centro fotossintético das bactérias fototróficas, foi utilizado o protocolo de Achenbach et al. (2001). Foi utilizado termociclador “Gene Amp. PCR System 2400” (Perkin-Elmer Cetus, Norwalk, Conn.). Os diferentes primers foram sintetizados pela Invitrogem ${ }^{\circledR}$. 
Tabela 4.6: Primers filogenéticos utilizados para o Domínio Bacteria, bactérias fototróficas púrpuras e BRS

\begin{tabular}{|c|c|c|c|}
\hline Primers & Grupo & Seqüência $\left(5^{\prime} \rightarrow 3^{\prime}\right)$ & Fonte \\
\hline $\begin{array}{l}968 \mathrm{FGC} \\
\text { GC clamp }\end{array}$ & Domínio Bacteria & $\begin{array}{l}\text { AACGCGAAGAACCTTAC } \\
\text { CGCCCGGGGCGCGCCCCGGGCGGGGCGGGGGC } \\
\text { ACGGGGGG }\end{array}$ & Nielsen et al. (1999). \\
\hline $1392 \mathrm{R}$ & & ACGGGCGGTGTGTAC & \\
\hline $\begin{array}{l}\text { pufM.557FGC } \\
\text { GC clamp }\end{array}$ & $\begin{array}{l}\text { Bactérias } \\
\text { fototróficas } \\
\text { púrpuras }\end{array}$ & $\begin{array}{l}\text { CGCACCTGGACTGGAC } \\
\text { CGCCCGCCGGGGCGCCCGGGCGGGGCGGGGGC } \\
\text { ACGGGGGG CGCACCTGGACTGGAC }\end{array}$ & Achenbach et al. (2001). \\
\hline pufM.750R & & CCCATGGTCCAGCGCCAGAA & \\
\hline $\begin{array}{l}\text { 341FGC } \\
\text { GC clamp } \\
907 \mathrm{R}\end{array}$ & $\begin{array}{l}\text { Bactérias redutoras } \\
\text { de sulfato }\end{array}$ & $\begin{array}{l}\text { CCTACGGGAGGCAGCAG } \\
\text { CCGCCGCCGCGCCCCGCGCCCGTCCCGCCGCCC } \\
\text { CCGCCC } \\
\text { CCGTCAATTCCTTTRAGTTT }\end{array}$ & Nakagawa et al. (2002). \\
\hline
\end{tabular}

O procedimento para o preparo da solução para PCR de uma amostra está apresentado na Tabela 4.7. As condições de amplificação por PCR estão apresentadas nas Tabelas 4.8 e 4.9 .

Tabela 4.7: Procedimento para o preparo do mix de PCR

\begin{tabular}{l|cc}
\hline \multicolumn{1}{c|}{ Soluções } & $\begin{array}{c}\text { Mix para Domínio } \\
\text { Bacteria e BRS }\end{array}$ & $\begin{array}{c}\text { Mix para } \\
\text { Bactérias fototróficas púrpuras }\end{array}$ \\
\hline Água ultrapurificada & $34 \mu \mathrm{L}$ & $35 \mu \mathrm{L}$ \\
Tampão 10X & $5 \mu \mathrm{L}$ & $5 \mu \mathrm{L}$ \\
$\mathrm{MgCl}_{2}$ & $1,5 \mu \mathrm{L}$ & $1,5 \mu \mathrm{L}$ \\
dNTPs & $5 \mu \mathrm{L}$ & $5 \mu \mathrm{L}$ \\
Primer forward & $1 \mu \mathrm{L}$ & $0,5 \mu \mathrm{L}$ \\
Primer reverse & $1 \mu \mathrm{L}$ & $0,5 \mu \mathrm{L}$ \\
Taq polimerase & $0,5 \mu \mathrm{L}$ & $0,5 \mu \mathrm{L}$ \\
DNA template & $2 \mu \mathrm{L}$ & $2 \mu \mathrm{L}$ \\
Total & $50 \mu \mathrm{L}$ & $50 \mu \mathrm{L}$ \\
\hline
\end{tabular}

Tabela 4.8: Condições utilizadas na programação do aparelho para amplificação por PCR

\begin{tabular}{l|ccccccc}
\hline & $\begin{array}{c}\text { Número } \\
\text { de ciclos }\end{array}$ & $\begin{array}{c}\text { Desnaturação } \\
\text { inicial }\end{array}$ & Desnaturação & Anelamento & Extensão & $\begin{array}{c}\text { Final da } \\
\text { extensão }\end{array}$ & Resfriamento \\
\hline $\begin{array}{l}\text { Domínio } \\
\text { Bacteria }\end{array}$ & 35 & $\begin{array}{c}94^{\circ} \mathrm{C} \\
5 \text { minutos }\end{array}$ & $\begin{array}{c}94^{\circ} \mathrm{C} \\
45 \text { segundos }\end{array}$ & $\begin{array}{c}38^{\circ} \mathrm{C} \\
1 \text { minuto }\end{array}$ & $\begin{array}{c}72^{\circ} \mathrm{C} \\
2 \text { minutos }\end{array}$ & $\begin{array}{c}72^{\circ} \mathrm{C} \\
10 \text { minutos }\end{array}$ & $4^{\circ} \mathrm{C}$ \\
\hline $\begin{array}{l}\text { Fototrófica } \\
\text { púrpura }\end{array}$ & 30 & $\begin{array}{c}94^{\circ} \mathrm{C} \\
3 \text { minutos }\end{array}$ & $\begin{array}{c}94^{\circ} \mathrm{C} \\
1 \text { minuto }\end{array}$ & $\begin{array}{c}55^{\circ} \mathrm{C} \\
1 \text { minuto }\end{array}$ & $\begin{array}{c}72^{\circ} \mathrm{C} \\
1 \text { minuto }\end{array}$ & $\begin{array}{c}72^{\circ} \mathrm{C} \\
10 \text { minutos }\end{array}$ & $4^{\circ} \mathrm{C}$ \\
\hline
\end{tabular}


Tabela 4.9: Condições utilizadas na programação do aparelho para amplificação por PCR para as BRS

\begin{tabular}{|c|c|c|c|c|c|c|c|}
\hline Grupo & $\begin{array}{l}\text { Número de } \\
\text { ciclos }\end{array}$ & $\begin{array}{c}\text { Desnaturação } \\
\text { inicial }\end{array}$ & Desnaturação & Anelamento & Extensão & $\begin{array}{l}\text { Final da } \\
\text { extensão }\end{array}$ & Resfriamento \\
\hline BRS & 35 & $\begin{array}{c}94^{\circ} \mathrm{C} \\
5 \text { minutos }\end{array}$ & $\begin{array}{c}94^{\circ} \mathrm{C} \\
45 \text { segundos } \\
94^{\circ} \mathrm{C} \\
45 \text { segundos }\end{array}$ & $\begin{array}{c}62^{\circ} \mathrm{C} \\
1 \text { minuto } \\
57^{\circ} \mathrm{C} \\
1 \text { minuto }\end{array}$ & $\begin{array}{c}72^{\circ} \mathrm{C} \\
90 \text { segundos } \\
72^{\circ} \mathrm{C} \\
90 \text { segundos }\end{array}$ & $\begin{array}{c}72^{\circ} \mathrm{C} \\
10 \text { minutos }\end{array}$ & $4^{\circ} \mathrm{C}$ \\
\hline
\end{tabular}

\subsubsection{Eletroforese em gel de agarose}

A eletroforese em gel de agarose foi aplicada para avaliar o produto resultante da extração do ácido nucléico e da amplificação por PCR. O procedimento experimental foi o mesmo, diferindo apenas no marcador molecular. Assim, para verificar o produto da extração do ácido nucléico foram usados agarose 1\% e Hight como marcador de elevada massa molecular. Para avaliar o produto da amplificação por PCR foram usados agarose 1\% e Low como marcador de baixa massa molecular (Anexo A3).

\subsubsection{Eletroforese em gel de gradiente desnaturante}

Essa análise foi realizada segundo o protocolo de Muyzer et al. (1993), que tem por objetivo a separação dos fragmentos dos genes amplificados por PCR. A separação desses fragmentos ocorre de acordo com o grau de desnaturação da dupla hélice de DNA, sob a ação de agentes desnaturantes como a uréia e a formamida (Anexo A4). Com intuito de facilitar a explicação dos DGGE realizados, considerou-se que uma banda particular observada no gel constitui, teoricamente, uma população de microrganismos. 


\subsubsection{Cálculo do coeficiente de similaridade}

Na comparação das bandas padrões do DGGE foi utilizado a equação (4.1), segundo Gillan et al. (1998). Essa equação permite calcular o coeficiente de similaridade (Cs) entre duas amostras, considerando o número de bandas do DGGE de cada amostra e o número de bandas comuns às amostras. O programa Phylip foi utilizado para calcular as matrizes de similaridade e da matriz de distância dos diferentes dendrogramas realizados. Os dendrogramas foram elaborados utilizando-se o método UPGMA e desenhadas com o programa Tree Illustrator, e o método de JACKARD para calcular as distâncias entre os diferentes agrupamentos.

$$
\mathrm{Cs}=2 \mathrm{~J} /(\mathrm{a}+\mathrm{b}) \times 100
$$

Sendo:

a - número de bandas do DGGE na amostra 1

b - número de bandas do DGGE na amostra 2

$\mathrm{J}$ - número de bandas comuns dos DGGE

Foram realizados cortes arbitrários (65\%-67\%) nas figuras dos diferentes dendrogramas, com intuito de melhor visualizar as porcentagens de similaridade dos agrupamentos verificados.

\subsubsection{Clonagem}

A amostra para a clonagem foi proveniente do DNA total extraído da cultura purificada de bactéria fototrófica púrpura, referente à primeira coleta realizada na primavera (outubro de 2004), na superfície da lagoa anaeróbia. Foram utilizados os primers do Domínio Bacteria e do centro fotossintético das bactérias fototróficas púrpuras. O produto de PCR foi misturado ao vetor TOPO TA Cloning ${ }^{\circledR}$ e imediatamente foi realizada a transformação (Anexo A5). 


\subsubsection{Identificação}

As amostras provenientes do recorte das bandas foram seqüenciadas empregando-se os mesmos primers (sem GC clamp) utilizados no DGGE referente ao Domínio Bacteria, centro fotossintético das bactérias fototróficas púrpuras e das BRS. No seqüenciamento da cultura purificada foram utilizados os primers do Domínio Bacteria e do centro fotossintético das bactérias fototróficas púrpuras.

A identificação dos diferentes microrganismos foi realizada utilizando-se um conjunto de reagentes para seqüenciamento automático baseados em didesoxinucleotídeos marcados com fluorocromos (chamados dye terminators). As concentrações de DNA molde e de primers seguiram as instruções dos fabricantes. As reações de seqüenciamento foram purificadas em coluna Sephadex G50 e aplicadas no seqüenciador Megabace 1000 da GE Healthcare. A análise foi feita pelo software Sequence Analyser 3.0 com basecaller Cimarron 3.12.

As seqüências foram checadas utilizando-se o programa DNA Star (SeqMan). O alinhamento foi realizado utilizando-se o Clustal $W$. A construção da árvore filogenética de consenso foi realizada utilizando-se o algoritmo de Neighbor-joining do software Mega 3.1.

\subsubsection{Análise estatística}

Foi realizada a análise de variância (ANOVA, da versão 7 do EXCEL) para verificar as remoções de nitrogênio amoniacal, nitrito e nitrato nas lagoas de estabilização, nos horários T1 e T3, para os diferentes pontos de coleta e épocas do ano. Quando a probabilidade (representado pelo valor de $\mathrm{p})$ é menor que $5 \%(\mathrm{p}<0,05)$, há indicação de que existem diferenças significativas entre as variáveis em estudo. 


\section{RESULTADOS E DISCUSSÃO}

As condições climáticas foram variáveis nas diferentes estações e horários de coleta. $\mathrm{Na}$ primavera, no dia anterior à coleta havia chovido. No dia da coleta fazia sol, muito vento e havia poucas nuvens no horário T0 $(08: 00 \mathrm{~h})$. No horário T3 $(02: 00 \mathrm{~h})$ ocorreu chuva fraca. Em T4 (08:00 h), fazia frio, com muito vento e céu nublado. A cor da superfície das lagoas era verde, indicando possivelmente a presença de algas.

No verão, no horário T0 (08:00 h) o céu estava nublado com vento. Em T1 (14:00 h), havia sol e o céu estava nublado. Em T2 (20:00 h) e T3 (02:00 h) havia muito vento. As superfícies da lagoa anaeróbia e facultativa eram verde-amarronzada e verde, respectivamente.

No outono, nos horários T0 (08:00 h), T1 (14:00 h) e T4 (08:00 h) havia muito sol, poucas nuvens e pouco vento. A superfície da lagoa anaeróbia era verde e na lagoa facultativa foi verificado um bloom de algas verdes.

No inverno, as condições climáticas eram de céu parcialmente nublado no horário diurno, presença de sol, nuvens e sem ocorrência de chuva. A superfície das lagoas era verde. As lagoas de estabilização não estavam em operação durante essa época do ano (desde junho de 2005). Não havia afluente e efluente na lagoa anaeróbia, e nem afluente na lagoa facultativa.

As observações visuais das superfícies das lagoas, nas quatro épocas do ano, não indicaram florescimentos de bactérias fototróficas púrpuras.

Há falta de dados, nas épocas das coletas, sobre a velocidade do vento em Cajati. A Tabela 5.1 mostra os dados da velocidade do vento, registrados em Jacupiranga (próximo a Cajati), com intuito de conhecer sua variabilidade nas épocas em que as coletas foram realizadas. Na primavera, foi verificada uma maior velocidade do vento, em relação 
às outras épocas do ano, com 5,4 m/s, exceto no horário T0 (08:00 h) (Figura 5.1). Nessa época foi verificada a menor diversidade dos diferentes microrganismos estudados. Possivelmente, a mistura das águas da lagoa, promovida pelo vento, juntamente com o período de chuva, favoreceram a perda de biomassa no sistema. Chuvas intensas podem provocar a diluição uma vez que aumentam a vazão, e também reduzem o tempo de detenção hidráulica (MENDONÇA, 2000). No verão, a velocidade máxima do vento verificada foi de $1,7 \mathrm{~m} / \mathrm{s}$. No outono, foi superior ao verificado no verão, com $3,3 \mathrm{~m} / \mathrm{s}$. Menores velocidades foram registradas no inverno, com velocidade máxima de $0,7 \mathrm{~m} / \mathrm{s}$.

Tabela 5.1: Valores do vento em Jacupiranga nas diferentes estações e horários de coleta

\begin{tabular}{c|cccc}
\hline & \multicolumn{4}{c}{$\begin{array}{c}\text { Velocidade } \\
\text { (m/s) }\end{array}$} \\
\hline $\begin{array}{c}\text { Horário } \\
\text { (horas) }\end{array}$ & Primavera & Verão & Outono & Inverno \\
\hline $08: 00$ & 1,0 & 1,3 & 0,4 & 0,4 \\
$14: 00$ & 5,4 & 1,7 & 3,3 & 0,7 \\
$20: 00$ & 3,2 & 1,2 & 1,6 & 0,4 \\
$02: 00$ & 1,7 & 0,4 & 0,4 & 0,4 \\
$08: 00$ & 1,9 & 0,5 & 0,6 & 0,5 \\
Valor & 2,64 & 1,02 & 1,26 & 0,48 \\
\multicolumn{2}{l}{ Médio } & & &
\end{tabular}

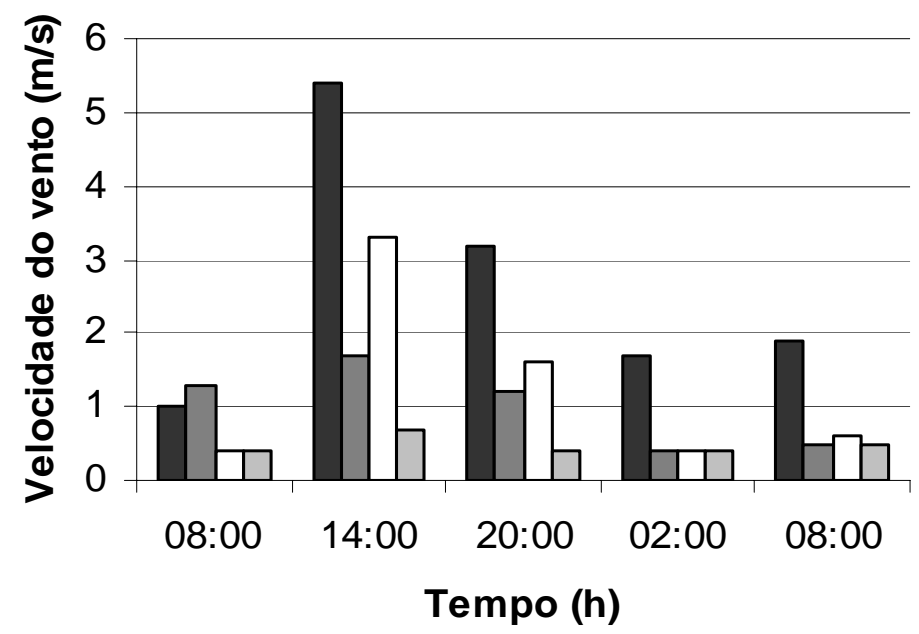

$\square$ Primavera
$\square$ Verão
$\square$ Outono
$\square$ Inverno

Figura 5.1: Velocidade do vento em Jacupiranga nos horários e épocas das coletas 
A Figura 5.2 mostra os valores médios de precipitação e de temperatura registrados em Cajati nos meses das coletas. A precipitação e a temperatura máxima foram verificadas na coleta realizada em janeiro (verão) com $305,0 \mathrm{~mm}$ e $25,8^{\circ} \mathrm{C}$, respectivamente; a menor precipitação foi verificada em abril (outono) com 115,0 mm, e a menor temperatura foi em julho (inverno), com $17,7^{\circ} \mathrm{C}$.

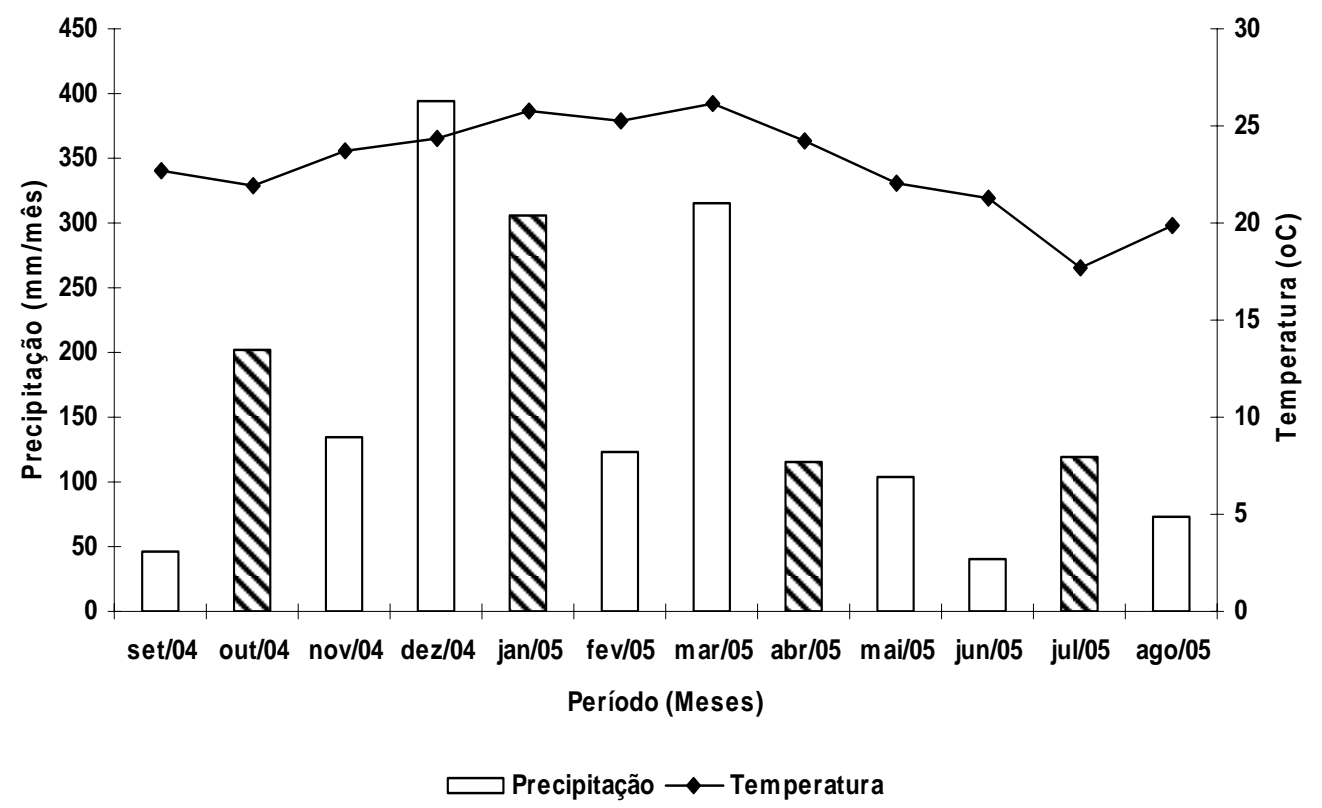

Figura 5.2: Valores de precipitação e de temperatura em Cajati nos horários e épocas das coletas 


\subsection{Lagoa Anaeróbia}

\subsubsection{Variações Sazonais do Domínio Bacteria}

\subsubsection{Amostragem Diurna}

A seguir encontra-se a descrição e discussão dos resultados referentes à distribuição dos microrganismos relacionados ao Domínio Bacteria obtidos para a lagoa anaeróbia. Esse domínio engloba todas as bactérias, sejam aeróbias, facultativas, anaeróbias, fototróficas anoxigênicas, redutoras de sulfato, fermentativas, e etc.

A partir do DGGE realizada com primers para o Domínio Bacteria, na amostra coletada na lagoa anaeróbia às 14:00 h (T1), foi elaborado o dendrograma apresentado na Figura 5.3. Corte arbitrário de $65 \%$ de similaridade foi realizado, sendo observados quatro agrupamentos principais.

O primeiro agrupamento mostrou que a distribuição dos microrganismos na subsuperfície e na camada intermediária, na primavera, apresentou $85 \%$ de similaridade. As populações observadas nessas profundidades foram $80 \%$ similares à verificada na interface água-sedimento, também na primavera. A radiação solar fotossinteticamente ativa incidente na superfície da lagoa, às 14:00 h, na primavera, foi de $545,8 \mu \mathrm{Em}^{-2} \mathrm{~s}^{-1}$. Os valores de $\mathrm{pH}$, temperatura e oxigênio dissolvido, na sub-superfície, foram de 9,$6 ; 23,4^{\circ} \mathrm{C}$ e $0,7 \mathrm{mg} / \mathrm{L}$, respectivamente. $\mathrm{Na}$ camada intermediária, os valores foram de 8,$9 ; 22,9^{\circ} \mathrm{C}$ e $0,05 \mathrm{mg} / \mathrm{L}$, respectivamente. Valores similares foram verificados também na interface água sedimento, e iguais a 8,$9 ; 22,9^{\circ} \mathrm{C}$ e $0,0 \mathrm{mg} / \mathrm{L}$, respectivamente. Com $\mathrm{pH}$ alcalino, temperatura mesofílica e condições anaeróbias, foram verificadas populações semelhantes de microrganismos nas diferentes profundidades (similaridade de $80 \%$ e $85 \%$ ).

Como mencionado anteriormente, na primavera, em Jacupiranga foi verificada maior velocidade do vento do que nas outras épocas do ano. Desse modo, a elevada similaridade de populações observada na lagoa anaeróbia indicou um sistema homogêneo, favorecido, provavelmente, pela ação do vento, uma vez que os valores obtidos para as demais variáveis foram próximos. 
O segundo agrupamento mostrou que a distribuição das bactérias, no outono, foi similar em $80 \%$ na sub-superfície e interface água-sedimento. Ambas profundidades apresentaram similaridade de $70 \%$, com a distribuição de bactérias verificada na camada intermediária, no outono. A radiação solar fotossinteticamente ativa incidente, na superfície da lagoa, no horário de coleta das 14:00 h, no outono, foi de 264,61 $\mu \mathrm{Em}^{-2} \mathrm{~s}^{-1}$. Os valores de $\mathrm{pH}$, temperatura e oxigênio dissolvido na sub-superfície foram de 9,$1 ; 35,1^{\circ} \mathrm{C}$ e $8,2 \mathrm{mg} / \mathrm{L}$, respectivamente. Os valores obtidos para a camada intermediária e a interface água sedimento foram iguais $(8,9$ e 8,9$),\left(22,9^{\circ} \mathrm{C}\right.$ e $\left.22,9^{\circ} \mathrm{C}\right)$ e $(0,05 \mathrm{mg} / \mathrm{L}$ e $0,0 \mathrm{mg} / \mathrm{L})$, respectivamente. A partir dessas informações, verificou-se que a concentração de oxigênio dissolvido não foi limitante, pois observou-se similaridade maior para a sub-superfície e interface água-sedimento apesar dos valores refletirem condições aeróbias e anaeróbias, respectivamente, em relação à camada intermediária, a qual também se mostrou anaeróbia. Provavelmente, as populações observadas nesse período de amostragem possuíam metabolismo facultativo e, distribuíram-se quase igualmente no perfil vertical da lagoa anaeróbia.

O terceiro agrupamento indicou que a distribuição das bactérias na sub-superfície, no verão, foi similar em $66 \%$ com o verificado no quarto agrupamento. Esse último apresentou similaridade de $90 \%$ e $73 \%$ em relação às bactérias presentes na camada intermediária e interface água-sedimento, no verão; e em relação a sub-superfície, camada intermediária e interface água-sedimento, no inverno, respectivamente. Um coeficiente de similaridade de $100 \%$ foi observado apenas para as populações presentes na camada intermediária e na interface água-sedimento, no inverno.

A radiação solar fotossinteticamente ativa incidente e os valores de $\mathrm{pH}$, temperatura e oxigênio dissolvido na sub-superfície da lagoa, no horário de coleta das 14:00 h, no verão foram iguais a $245,5 \mu \mathrm{Em}^{-2} \mathrm{~s}^{-1}, 10,9 ; 33,0^{\circ} \mathrm{C}$ e $7,4 \mathrm{mg} / \mathrm{L}$, respectivamente. Tais condições contribuíram para a formação de um único agrupamento, com menor coeficiente de similaridade (66\%), devido, possivelmente, ao maior valor de $\mathrm{pH}$, quando comparado com os registrados em outras épocas do ano.

Os valores de $\mathrm{pH}$, temperatura e oxigênio dissolvido na camada intermediária, no verão, foram de 9,$2 ; 25,9^{\circ} \mathrm{C}$ e $0,1 \mathrm{mg} / \mathrm{L}$, respectivamente. Na interface água-sedimento, os valores foram de 9,$2 ; 25,2^{\circ} \mathrm{C}$ e $0,08 \mathrm{mg} / \mathrm{L}$, respectivamente. Esses valores próximos de $\mathrm{pH}$ 
alcalino, temperatura mesofílica e baixa concentração de oxigênio dissolvido possibilitaram que os microrganismos se distribuíssem de formas semelhantes na camada intermediária e na interface água-sedimento ( similaridade de $90 \%$ ), no verão, porém, diferente em relação à distribuição encontrada na sub-superfície para o mesmo período. Além do valor de $\mathrm{pH}$ $(10,9)$ ligeiramente maior na sub-superfície da lagoa, provavelmente, a constatação de populações distintas nessa camada tenha sido devido à alta concentração de oxigênio dissolvido (7,44 mg/L), a qual favoreceu o crescimento de bactérias aeróbias, em relação àquelas características de condições de anaerobiose, observadas na camada intermediária e na interface água-sedimento $(0,1 \mathrm{mg} / \mathrm{L}$ e $0,08 \mathrm{mg} / \mathrm{L}$, respectivamente).

A radiação solar fotossinteticamente ativa incidente, na superfície da lagoa, no horário de coleta das 14:00 h, no inverno, foi de 574,8 $\mu \mathrm{Em}^{-2} \mathrm{~s}^{-1}$. Os valores de $\mathrm{pH}$, temperatura e oxigênio dissolvido na sub-superfície foram de 9,$4 ; 26,9^{\circ} \mathrm{C}$ e $8,2 \mathrm{mg} / \mathrm{L}$, respectivamente. $\mathrm{Na}$ camada intermediária, os valores foram de 8,$9 ; 19,6^{\circ} \mathrm{C}$ e $1,6 \mathrm{mg} / \mathrm{L}$, respectivamente. Na interface água-sedimento, os valores foram de 8,$2 ; 19,6^{\circ} \mathrm{C}$ e $0,9 \mathrm{mg} / \mathrm{L}$, respectivamente. Sob essas condições físico-químicas, obteve-se $73 \%$ de similaridade na distribuição dos microrganismos na sub-superfície, com as verificadas na camada intermediária e na interface água-sedimento. Nessas profundidades (camada intermediária e interface água-sedimento) foram verificadas idênticas distribuições dos microrganismos; ou seja, similaridade de $100 \%$. Essa similaridade de populações justifica-se, uma vez que os valores de temperatura, $\mathrm{pH}$ e oxigênio dissolvido foram praticamente os mesmos, favorecendo a distribuição de populações semelhantes, além da lagoa não estar em operação nessa época da coleta.

Avaliando o perfil de bandas padrões do DGGE realizado com primers para o Domínio Bacteria, observou-se menor e maior diversidade de bactérias, nas três profundidades avaliadas; ou seja, na primavera foram observadas 5, 6 e 5 populações para a sub-superfície, camada intermediária e interface água-sedimento, respectivamente. Todavia, no outono foram constatadas 9,8 e 12 populações, respectivamente. Diversidades intermediárias foram verificadas no verão ( 9,8 e 9 bandas), e no inverno (8, 5 e 5 bandas), respectivamente. $\mathrm{Na}$ primavera e no inverno foram verificadas as maiores valores de radiação solar fotossinteticamente ativa incidente $\left(545,8 \mu \mathrm{Em}^{-2} \mathrm{~s}^{-1}\right.$ e $574,8 \mu \mathrm{Em}^{-2} \mathrm{~s}^{-1}$, respectivamente), em relação àqueles registrados no verão e no outono $\left(245,5 \mu \mathrm{Em}^{-2} \mathrm{~s}^{-1} \mathrm{e}\right.$ 
264,6 $\mu \mathrm{Em}^{-2} \mathrm{~s}^{-1}$, respectivamente). Na sub-superfície, no verão e outono, com intensidades luminosas similares foram verificadas 9 bandas em ambas as épocas do ano. Por outro lado, valores similares de oxigênio dissolvido favoreceram a presença de populações semelhantes na camada intermediária e na interface água sedimento, no outono e verão. Portanto, menores valores de intensidade luminosa e oxigênio dissolvido favoreceram maior diversidade de bactérias na lagoa anaeróbia.

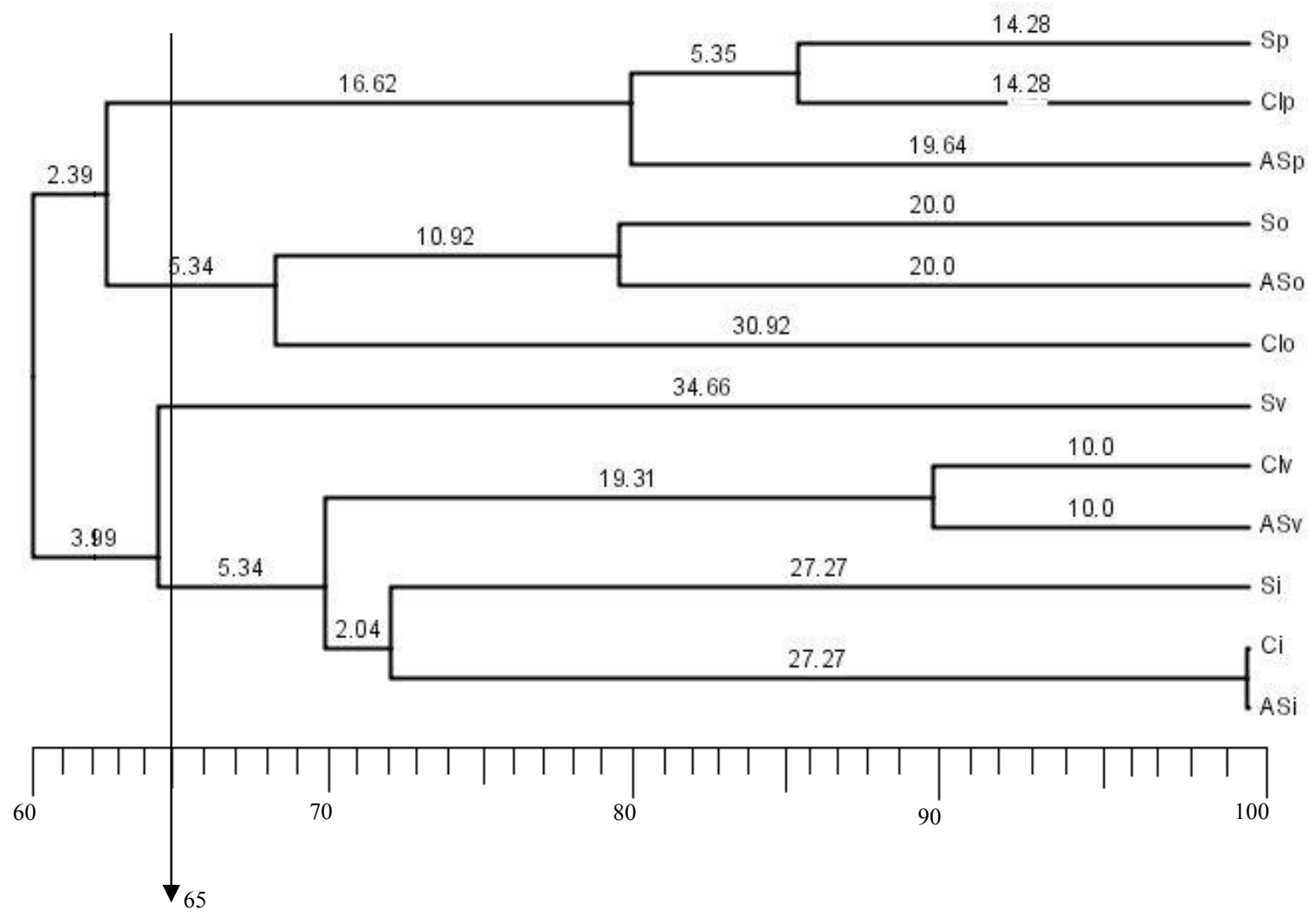

Figura 5.3: Dendrograma das variações sazonais na lagoa anaeróbia com primers para o Domínio Bacteria referente ao horário (T1) (14:00 h)

$\mathrm{S}=$ sub-superfície, $\mathrm{CI}=$ camada intermediária, $\mathrm{AS}=$ interface água-sedimento. A régua indica porcentagens do coeficiente de similaridade 
Os valores mínimo e máximo de $\mathrm{pH}$ foram de 7,0, no outono, e 10,9 no verão, respectivamente (Anexos B1, B7, B13 e B19) (Figura 5.4). O pH afluente variou de 8,1 na primavera, a 9,4 no verão. Todavia, no outono o valor foi de 7,0. Segundo von Sperling (1996), os valores de pH para lagoas de estabilização devem estar compreendidos na faixa entre 6,7 a 7,5. A variação de pH afluente verificada por Falco (2005), nas lagoas de estabilização de Novo Horizonte (SP), foi de 5,9, no outono, a 7,3, no verão. Desse modo, os valores de $\mathrm{pH}$ obtidos para a lagoa anaeróbia de Cajati foram maiores em relação àqueles descritos em estudos realizados em lagoas de estabilização.

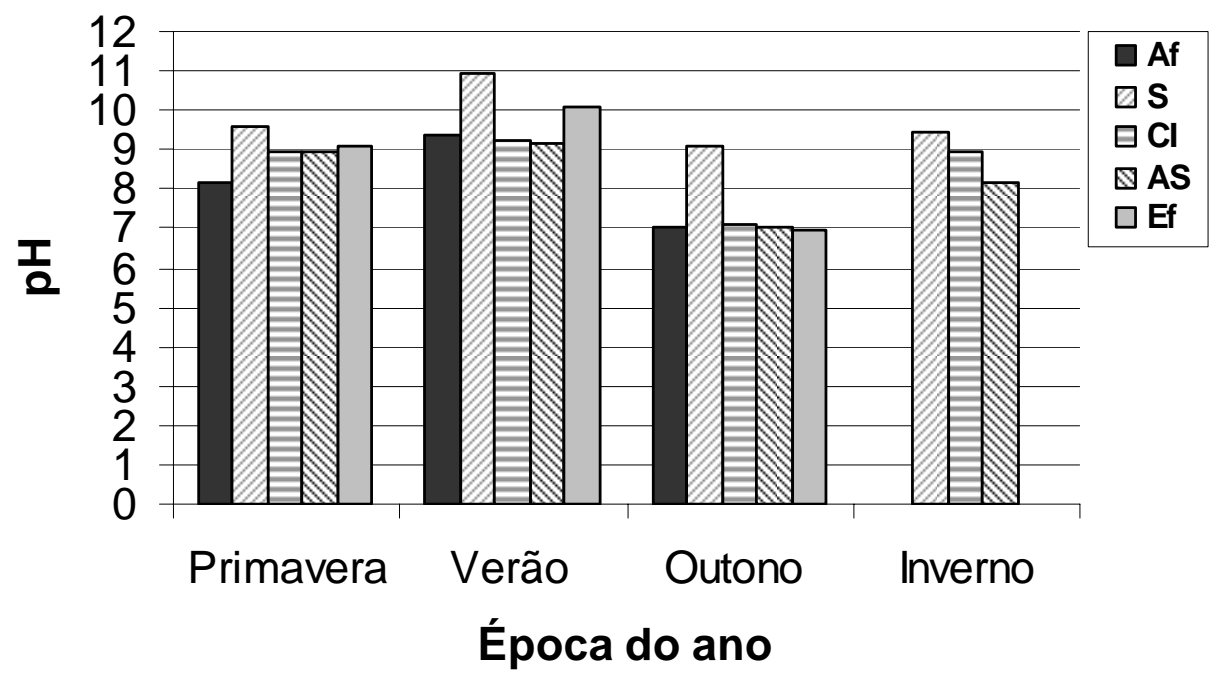

Figura 5.4: Variação sazonal de pH na lagoa anaeróbia referente ao horário T1 (14:00 h) $\mathrm{Af}=$ afluente, $\mathrm{S}=$ sub-superfície, $\mathrm{CI}=$ camada intermediária, $\mathrm{AS}=$ interface água-sedimento, $\mathrm{Ef}=$ efluente

$\mathrm{Na}$ sub-superfície, na primavera e no inverno, os valores de temperatura foram de $23,4^{\circ} \mathrm{C}$ e $26,9^{\circ} \mathrm{C}$, respectivamente. Todavia, no verão e outono os valores foram ligeiramente maiores e iguais a $33,0^{\circ} \mathrm{C}$ e $35,1^{\circ} \mathrm{C}$, respectivamente. Nos demais pontos de amostragem, no verão e outono, a temperatura foi próxima de $25^{\circ} \mathrm{C}$, enquanto no inverno atingiu $19,6^{\circ} \mathrm{C}$ (Figura 5.5). A temperatura afluente variou de $23,5^{\circ} \mathrm{C}$, na primavera, a 27, $8^{\circ} \mathrm{C}$, no outono (Anexos B1, B7, B13 e B19). Gomes (2002) verificou valores similares de temperatura afluente na lagoa de estabilização de Coroados (Brasil), variando de $24,0^{\circ} \mathrm{C}$, no inverno, a $26,0^{\circ} \mathrm{C}$, no outono; e na lagoa de estabilização de Lourdes, variando de 
$21,0^{\circ} \mathrm{C}$, no inverno, a $26,0^{\circ} \mathrm{C}$, no outono. A variação da temperatura afluente verificada por Falco (2005), em lagoas de estabilização de ambiente tropical foi de $26,9^{\circ} \mathrm{C}$, no inverno, a $30,6^{\circ} \mathrm{C}$, no verão.

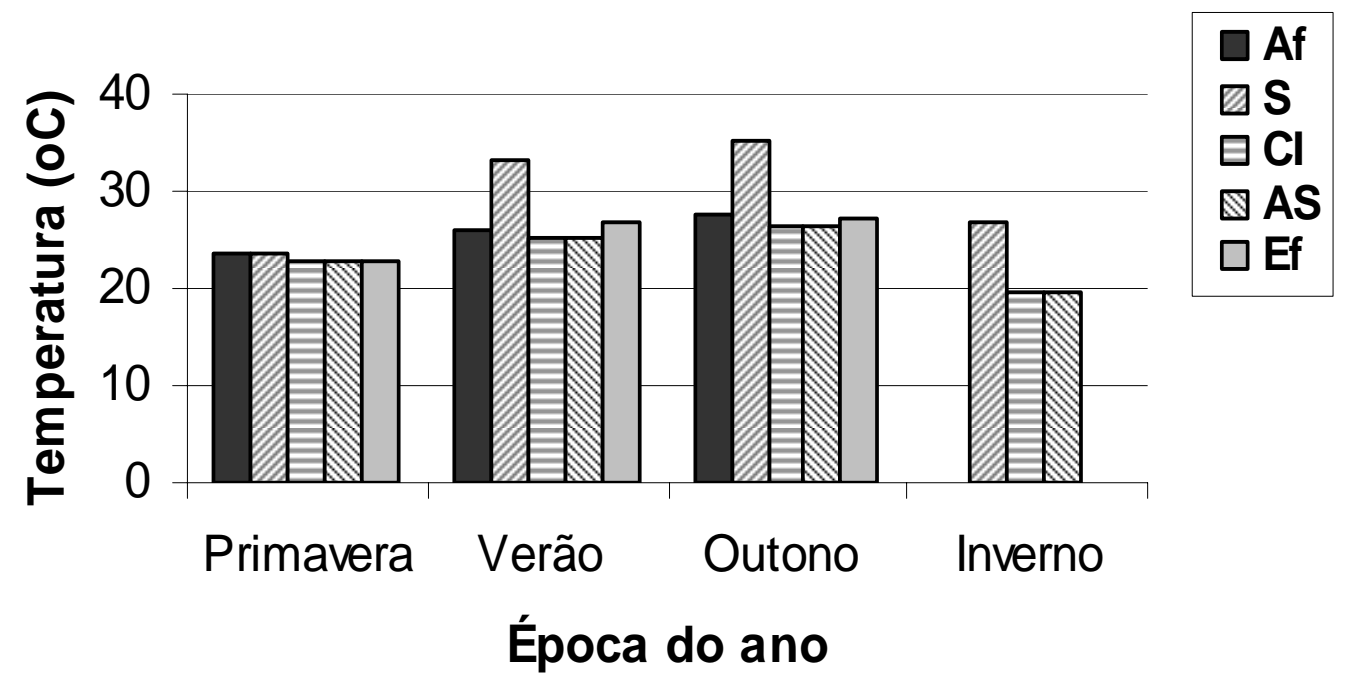

Figura 5.5: Variação sazonal da temperatura na lagoa anaeróbia nas diferentes épocas do ano referente ao horário $\mathrm{T} 1 \mathrm{(14:00 \textrm {h } )}$

$\mathrm{Af}=$ afluente, $\mathrm{S}=$ sub-superfície, $\mathrm{CI}=$ camada intermediária, $\mathrm{AS}=$ interface água-sedimento, $\mathrm{Ef}=$ efluente

Concentração de oxigênio dissolvido na sub-superfície, na primavera, foi de 0,7 $\mathrm{mg} / \mathrm{L}$; e no verão e outono, de 7,4 mg/L e $8,2 \mathrm{mg} / \mathrm{L}$, respectivamente. Possivelmente, essas diferentes concentrações de oxigênio dissolvido permitiram, também, a menor (primavera) e as maiores (outono, verão e inverno) diversidades de bactérias em diferentes épocas. As concentrações de oxigênio dissolvido, encontradas na camada intermediária e interface água-sedimento, variaram de $0,0 \mathrm{mg} / \mathrm{L}$ na primavera e outono, a $1,6 \mathrm{mg} / \mathrm{L}$ no inverno, proporcionando condições para o crescimento de microrganismos anaeróbios e microaerófilos.

As concentrações mínima e máxima de oxigênio dissolvido ocorreram no outono e foram de $0,0 \mathrm{mg} / \mathrm{L}$ e $8,2 \mathrm{mg} / \mathrm{L}$, respectivamente (Figura 5.6). A concentração de oxigênio dissolvido afluente variou de $0,5 \mathrm{mg} / \mathrm{L}$ no outono, a $3,1 \mathrm{mg} / \mathrm{L}$ na primavera (Anexos B1, B7, B13 e B19). Nas lagoas anaeróbias a existência de condições estritamente anaeróbias é essencial para a estabilização da matéria orgânica, as quais são obtidas através do 
lançamento de grande carga de DBO por unidade de volume da lagoa, o que faz com que a taxa de consumo de oxigênio seja várias vezes superior à taxa de produção (von SPERLING, 1996). Na presente pesquisa, não foram verificadas condições estritamente anaeróbias nos diferentes pontos de coleta e épocas do ano, o que possivelmente favoreceu a presença de microrganismos tolerantes à presença de oxigênio dissolvido na lagoa anaeróbia.

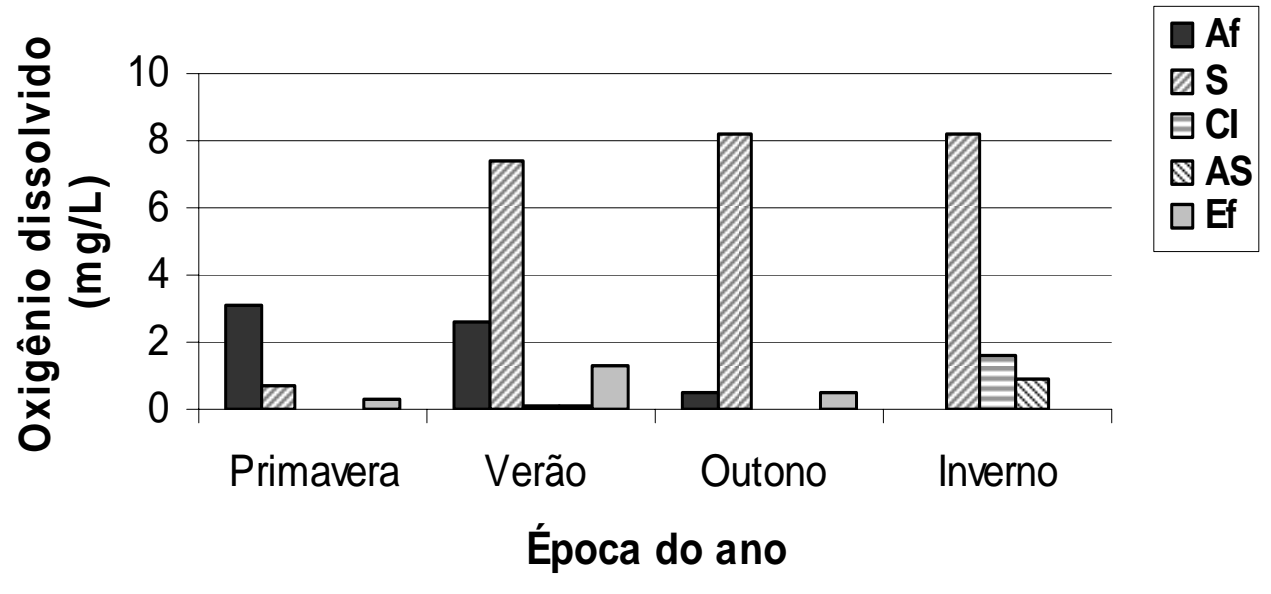

Figura 5.6: Variações sazonais de oxigênio dissolvido na lagoa anaeróbia referente ao horário T1 $(14: 00 \mathrm{~h})$

Af $=$ afluente, $\mathrm{S}=$ sub-superfície, $\mathrm{CI}=$ camada intermediária, $\mathrm{AS}=$ interface água-sedimento, $\mathrm{Ef}=$ efluente

As concentrações de sulfato na sub-superfície, na primavera e no inverno foram de $3,0 \mathrm{mg} / \mathrm{L}$ e 4,0 mg/L, respectivamente. No verão e outono, os valores foram iguais a 21,0 $\mathrm{mg} / \mathrm{L}$ e $12,0 \mathrm{mg} / \mathrm{L}$, respectivamente (Figura 5.7). A concentração afluente de sulfato variou de 48,0 mg/L na primavera, a 57,0 mg/L no outono (Anexos B1, B7, B13 e B19). Algas, fungos e bactérias utilizam o sulfato no processo de redução assimilativa. Por outro lado, as BRS usam esse composto no processo de redução desassimilativa, com formação de sulfeto de hidrogênio (MADIGAN et al., 2006). Provavelmente, a maior diversidade de bactérias tenha sido favorecida pelas maiores concentrações de sulfato encontradas no verão e outono, em relação à primavera e ao inverno, respectivamente. Destaca-se, contudo, que as concentrações de sulfato observadas favoreceram sobremaneira a redução assimilativa, uma vez que um valor maior dessa fonte de enxofre é necessário para o processo 
desassimilativo. Silva (2004) verificou que para uma relação DQO/sulfato de 0,9, Desulfococcus, bactéria redutora de sulfato, reduziu $960 \mathrm{mg} / \mathrm{L}$ deste. Portanto, as concentrações de sulfato observadas na lagoa anaeróbia favoreceram o processo anabólico envolvendo a síntese de proteínas, ácidos nucléicos, enzimas e etc.

Segundo Mendonça (2000), condições favoráveis para a redução desassimilativa ocorrem quando a concentração de oxigênio é baixa $(<0,16 \mathrm{mg} / \mathrm{L})$ e a temperatura é superior a $15^{\circ} \mathrm{C}$. Na lagoa anaeróbia, as concentrações de oxigênio dissolvido, verificadas na camada intermediária e na interface água-sedimento variaram entre $0,05 \mathrm{mg} / \mathrm{L}$ a 0,8 $\mathrm{mg} / \mathrm{L}$. Os valores de temperatura foram de $19,6^{\circ} \mathrm{C}$ no inverno, a $26,5^{\circ} \mathrm{C}$ no outono. Esses valores verificados na camada intermediária e na interface água-sedimento favoreceram, possivelmente, a redução assimilativa. Foi observada na superfície da lagoa anaeróbia, nas diferentes coletas realizadas, a presença de odor fétido e de borbulhas de gás, possivelmente devido à presença de $\mathrm{H}_{2} \mathrm{~S}$.

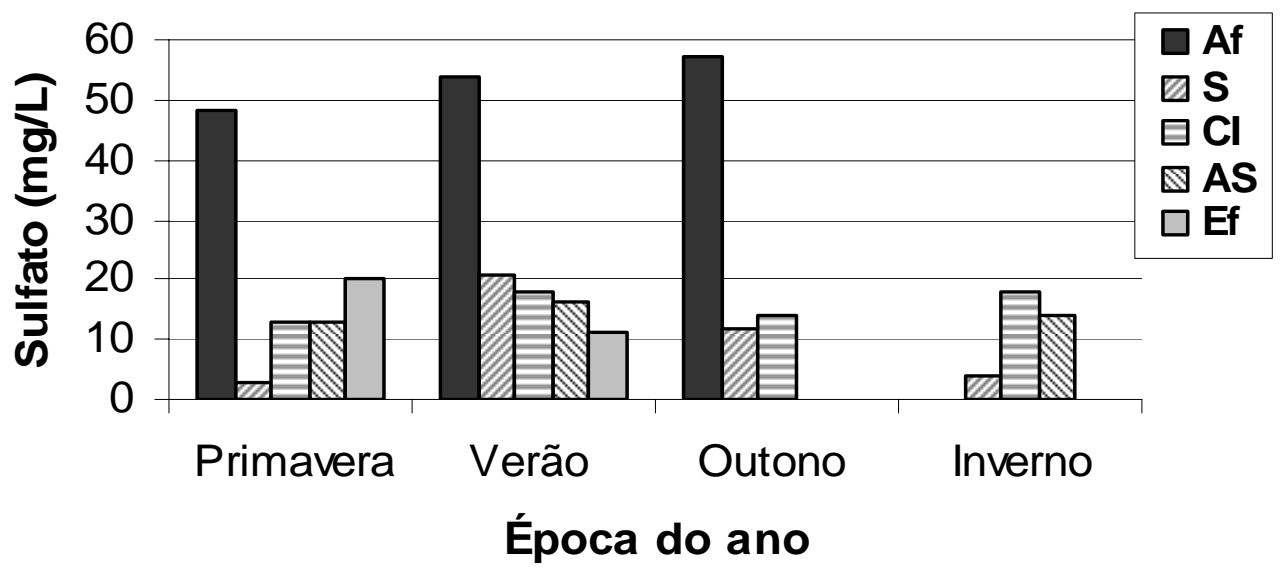

Figura 5.7: Variações sazonais de sulfato na lagoa anaeróbia referente ao horário T1 (14:00 h) $\mathrm{Af}=$ afluente, $\mathrm{S}=$ sub-superfície, $\mathrm{CI}=$ camada intermediária, $\mathrm{AS}=$ interface água-sedimento, $\mathrm{Ef}=$ efluente

A quantidade de matéria orgânica $\left(\mathrm{DQO}_{\mathrm{b}}\right)$ variou de $60,3 \mathrm{mg} / \mathrm{L}$ no inverno, a 298,0 $\mathrm{mg} / \mathrm{L}$ na primavera. Os valores da matéria orgânica bruta $\left(\mathrm{DQO}_{\mathrm{b}}\right)$ na sub-superfície, na primavera e no inverno foram de 196,0 mg/L e 99,7 mg/L, respectivamente. No verão e outono, os valores foram de 130,0 mg/L e 109,5 mg/L, respectivamente (Figura 5.8). No afluente, esta variou de 50,0 mg/L na primavera, a 290,0 mg/L no verão (Anexos B1, B7, 
B13 e B19). Gomes (2002) obteve valores superiores de $\mathrm{DQO}_{\mathrm{b}}$ afluente, na lagoa de estabilização de Coroados, variando de $1.103 \mathrm{mg} / \mathrm{L}$ no inverno, a $1.207 \mathrm{mg} / \mathrm{L}$ no outono; e na lagoa de estabilização de Lourdes, de 959,0 mg/L no inverno, a $2.992 \mathrm{mg} / \mathrm{L}$ no outono. Valores superiores, da $\mathrm{DQO}_{\mathrm{b}}$ afluente também foram verificados por Falco (2005), de $880,0 \mathrm{mg} / \mathrm{L}$ no verão, a $1.285 \mathrm{mg} / \mathrm{L}$ no inverno. Portanto, os valores de $\mathrm{DQO}_{\mathrm{b}}$ obtidos para a lagoa anaeróbia de Cajati (SP) foram inferiores, até mesmo para aqueles normalmente observados para o esgoto sanitário.

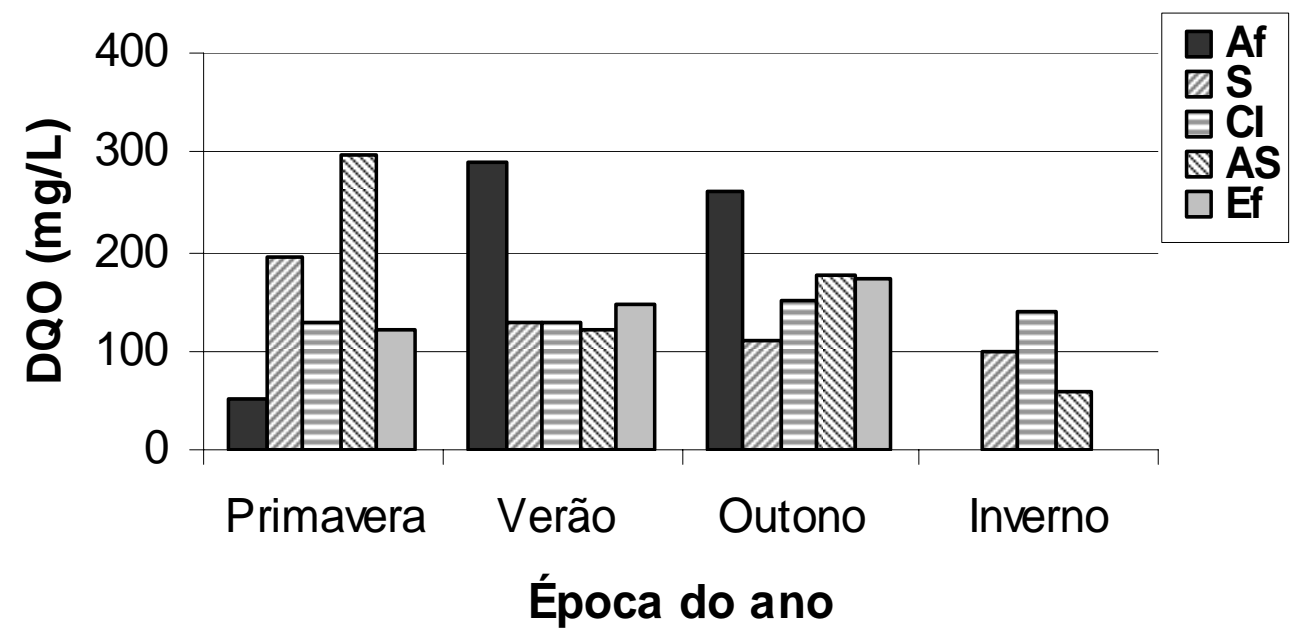

Figura 5.8: Variações sazonais de matéria orgânica na lagoa anaeróbia referente ao horário T1 $(14: 00 \mathrm{~h})$

$\mathrm{Af}=$ afluente, $\mathrm{S}=$ sub-superfície, $\mathrm{CI}=$ camada intermediária, $\mathrm{AS}=$ interface água-sedimento, $\mathrm{Ef}=$ efluente

As concentrações de sólidos suspensos voláteis (SSV) na sub-superfície, na primavera e no inverno (193,0 mg/L e 73,0 mg/L, respectivamente), foram superiores aos verificados no verão e outono (0,0 mg/L e 67,0 mg/L, respectivamente). Possivelmente, as maiores concentrações de sólidos suspensos voláteis, na primavera e inverno foram devidos à presença de outros organismos, tais como algas e protozoários. Fato também verificado na camada intermediária e na interface água-sedimento, onde as concentrações de sólidos suspensos voláteis, no verão e outono foram de 13,0 e 70,0 mg/L; e 40,0 e 93,0 mg/L, respectivamente, ou seja, menores em relação aos verificados na primavera e inverno (153,0 e 120,0 mg/L; e 190,0 e 113,0 mg/L, respectivamente) ou maiores valores de SSV verificados na primavera foram relacionados à maior intensidade do vento, quando comparada com as que ocorreram em outras estações, a qual provocou a ressuspenção dos 
sólidos sedimentáveis da lagoa anaeróbia (Figura 5.9). Todavia, é importante relembrar que no inverno a lagoa não se encontrava em operação, contribuindo para o registro de valores maiores de SSV.

As variações sazonais de concentração de sólidos suspensos voláteis foram de 0,0 $\mathrm{mg} / \mathrm{L}$ no verão e outono, a $213,0 \mathrm{mg} / \mathrm{L}$ na primavera. No afluente, variou de $60,0 \mathrm{mg} / \mathrm{L}$ no verão, a 120,0 mg/L na primavera (Anexos B1, B7, B13 e B19). Gomes (2002) obteve valores superiores de SSV no afluente da lagoa de estabilização de Coroados, variando de 265,0 mg/L no inverno, a 333,0 mg/L no outono; e na lagoa de estabilização de Lourdes, variando de 295,0 mg/L no inverno, a 580,0 mg/L no outono. Falco (2005) obteve, também, valores superiores de SSV afluente, variando de 221,0 mg/L no outono, a 313,0 $\mathrm{mg} / \mathrm{L}$ no inverno.

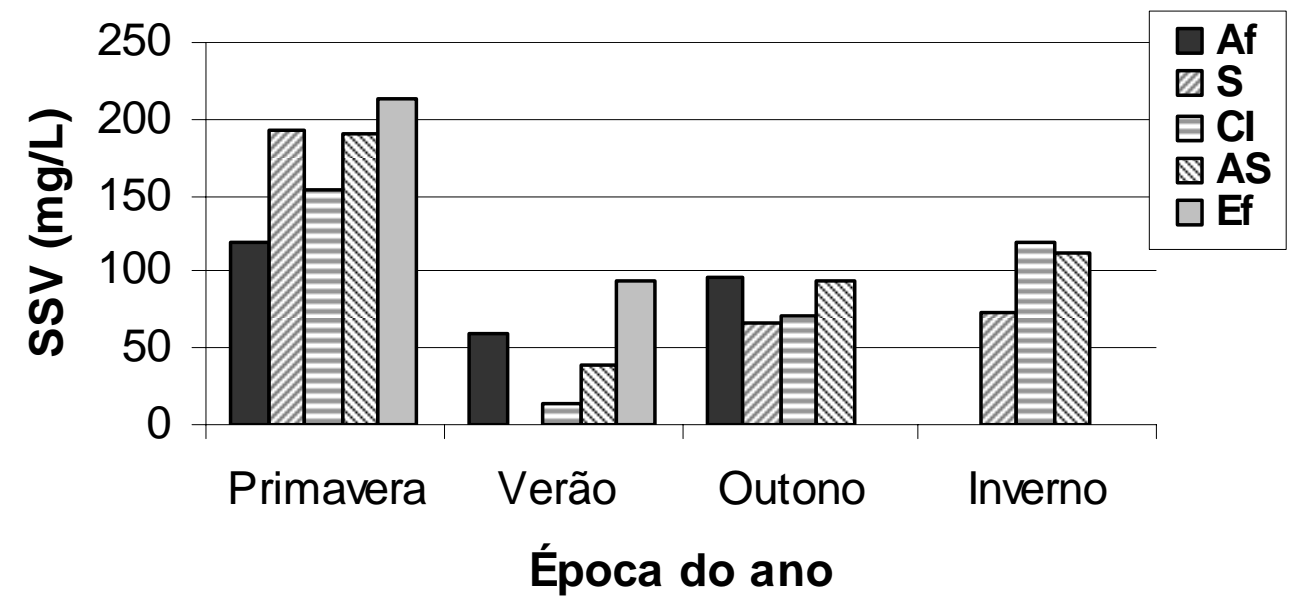

Figura 5.9: Variações sazonais de SSV na lagoa anaeróbia referente ao horário T1 (14:00 h) $\mathrm{Af}=$ afluente, $\mathrm{S}=$ sub-superfície, $\mathrm{CI}=$ camada intermediária, $\mathrm{AS}=$ interface água-sedimento, $\mathrm{Ef}=$ efluente

O nitrogênio total Kjeldahl compreende as formas reduzidas de nitrogênio, tais como o nitrogênio orgânico e o amoniacal. As concentrações de nitrogênio total Kjeldahl (NTK) na sub-superfície, na primavera e inverno, foram de 40,1 mg/L e 20,4 mg/L, respectivamente. No verão e outono, os valores foram iguais a $10,7 \mathrm{mg} / \mathrm{L}$ e 13,2 mg/L, respectivamente. As concentrações mínima e máxima foram de $10,7 \mathrm{mg} / \mathrm{L}$ no verão, e de $40,1 \mathrm{mg} / \mathrm{L}$ na primavera, respectivamente (Figura 5.10). No afluente, o NTK variou de 13,1 $\mathrm{mg} / \mathrm{L}$ na primavera, a 39,8 mg/L no outono (Anexos B2, B8, B14 e B20). Falco (2005) 
relatou uma concentração afluente de nitrogênio total Kjeldahl superior; ou seja, variando de $76,0 \mathrm{mg} / \mathrm{L}$ na primavera, a $104,0 \mathrm{mg} / \mathrm{L}$ no inverno.

O nitrogênio amoniacal afluente variou de $7,9 \mathrm{mg} / \mathrm{L}$ na primavera, a $29,8 \mathrm{mg} / \mathrm{L}$ no outono. Falco (2005) registrou no afluente, valores superiores de nitrogênio amoniacal, variando de $54,0 \mathrm{mg} / \mathrm{L}$ na primavera, a $68,0 \mathrm{mg} / \mathrm{L}$ no inverno.

As concentrações de nitrato na sub-superfície, na primavera e inverno foram de 2,0 $\mathrm{mg} / \mathrm{L}$ e $1,5 \mathrm{mg} / \mathrm{L}$, respectivamente. No verão e outono, os valores foram iguais a $1,8 \mathrm{mg} / \mathrm{L} \mathrm{e}$ 4,6 mg/L, respectivamente. As concentrações de nitrito na sub-superfície, na primavera e inverno foram de $18,9 \mu \mathrm{g} / \mathrm{L}$ e $2,1 \mu \mathrm{g} / \mathrm{L}$, respectivamente. No verão e outono, os valores foram iguais a $8,1 \mu \mathrm{g} / \mathrm{L}$ e $3,1 \mu \mathrm{g} / \mathrm{L}$, respectivamente. A variação da concentração de nitrito afluente foi de $8,9 \mu \mathrm{g} / \mathrm{L}$ na primavera, a $15,5 \mu \mathrm{g} / \mathrm{L}$ no outono. O nitrato afluente variou de $2,1 \mathrm{mg} / \mathrm{L}$ na primavera, a $3,7 \mathrm{mg} / \mathrm{L}$ no verão. Provavelmente, as concentrações de nitrogênio amoniacal e oxigênio dissolvido favoreceram o crescimento de bactérias nitrificantes. Todavia, na camada intermediária e na interface água-sedimento as concentrações de oxigênio dissolvido foram reduzidas, favorecendo a ocorrência da desnitrificação. Por outro lado, outras bactérias puderam utilizar esses compostos como fonte de nitrogênio para o crescimento.

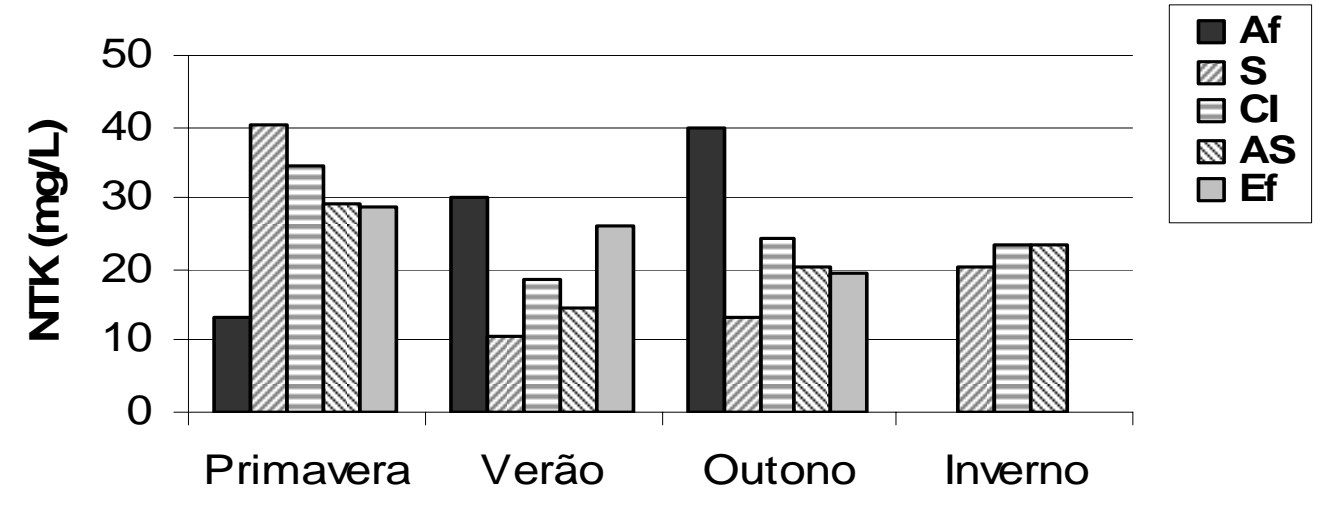

\section{Época do ano}

Figura 5.10: Variações sazonais de NTK na lagoa anaeróbia referente ao horário T1 (14:00 h) $\mathrm{Af}=$ afluente, $\mathrm{S}=$ sub-superfície, $\mathrm{CI}=$ camada intermediária, $\mathrm{AS}=$ interface água-sedimento, $\mathrm{Ef}=$ efluente 
As concentrações de fósforo total na sub-superfície, na primavera e inverno foram de 4,1 mg/L e 3,0 mg/L, respectivamente. No verão e outono, os valores foram iguais a 1,0 $\mathrm{mg} / \mathrm{L}$ e $2,6 \mathrm{mg} / \mathrm{L}$, respectivamente (Figura 5.11). As concentrações de fósforo total dissolvido na sub-superfície, na primavera e inverno, foram de $1,1 \mathrm{mg} / \mathrm{L}$ e $3,8 \mathrm{mg} / \mathrm{L}$, respectivamente. No verão e outono, os valores foram iguais a $1,1 \mathrm{mg} / \mathrm{L}$ e 2,0 mg/L, respectivamente.

As concentrações de ortofosfato na sub-superfície, na primavera e inverno foram de $0,6 \mathrm{mg} / \mathrm{L}$ e $1,4 \mathrm{mg} / \mathrm{L}$, respectivamente. No verão e outono, os valores foram iguais a 0,9 $\mathrm{mg} / \mathrm{L}$ e $1,7 \mathrm{mg} / \mathrm{L}$, respectivamente.

As concentrações mínima e máxima de fósforo total foram de $1,0 \mathrm{mg} / \mathrm{L}$ no verão, e $4,2 \mathrm{mg} / \mathrm{L}$ na primavera. No afluente, variou de $1,1 \mathrm{mg} / \mathrm{L}$ no verão, a $6,8 \mathrm{mg} / \mathrm{L}$ na primavera (Anexos B2, B8, B14 e B20). Gomes (2002) obteve valores superiores de fósforo total afluente, na lagoa de estabilização de Coroados, variando de $15,98 \mathrm{mg} / \mathrm{L}$ no inverno, a 29,02 mg/L no outono; e na lagoa de estabilização de Lourdes, variando de 7,84 mg/L na primavera, a 23,23 mg/L no inverno. Falco (2005) registrou, também, valores superiores de fósforo total no afluente, variando de 9,0 mg/L no verão, a 29,0 mg/L na primavera.

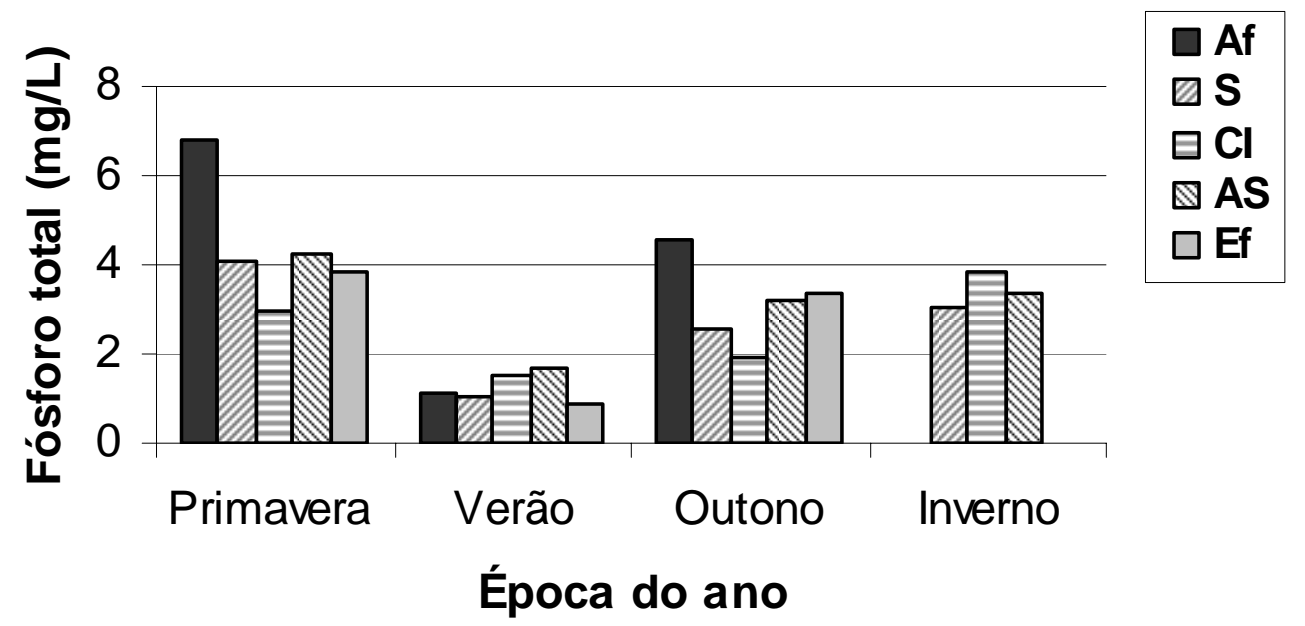

Figura 5.11: Variações sazonais de fósforo total na lagoa anaeróbia referente ao horário T1 (14:00 h)

$\mathrm{Af}=$ afluente, $\mathrm{S}=$ sub-superfície, $\mathrm{CI}=$ camada intermediária, $\mathrm{AS}=$ interface água-sedimento, $\mathrm{Ef}=$ efluente 


\subsubsection{Amostragem Noturna}

A partir do DGGE realizado com primers para o Domínio Bacteria, de amostra da lagoa anaeróbia coletada às 02:00 h (T3) foi elaborado o dendrograma da Figura 5.12. Corte arbitrário de $65 \%$ de similaridade foi realizado e, portanto, foram observados três agrupamentos principais. No primeiro agrupamento, as distribuições dos microrganismos na sub-superfície e na camada intermediária, na primavera, apresentaram $100 \%$ de similaridade, assim como no segundo agrupamento (camada intermediária e interface água sedimento, no verão); e no terceiro agrupamento (sub-superfície e camada intermediária, no inverno).

A distribuição dos microrganismos na interface água-sedimento, na primavera, foi similar à verificada na sub-superfície, no verão ( $80 \%$ de similaridade), assim como na camada intermediária e na interface água-sedimento, no outono ( $85 \%$ de similaridade).

Verificou-se, também, assim como foi observado no horário de coleta das 14:00 h, maior riqueza do Domínio Bacteria no outono, seguido pelo verão, inverno e primavera. Comparando-se os coeficientes de similaridade de ambos os horários de coleta, nas diferentes épocas do ano, os valores foram próximos, variando em T1 de 62-90\%, e em T3 de 57-85\%. Tais porcentagens indicaram alteração na diversidade de bactérias nesse intervalo de tempo; ou seja, de 12 horas entre as coletas dos horários T1 e T3 e, também, nas diferentes estações do ano. Algumas populações mantiveram-se nas quatro estações, indicando que representam, possivelmente, as populações autóctones na lagoa anaeróbia.

Nas coletas realizadas no verão e outono, no horário de coleta das 14:00 h, foram verificadas na sub-superfície, camada intermediária e interface água-sedimento, maior diversidade do Domínio Bacteria, com 9, 8 e 9, e 9, 8 e 12 populações, respectivamente. No horário de coleta das 02:00 h foram verificadas maiores diversidades no verão, outono e inverno, com (4, 9 e 9); (9, 10 e 12); e (9, 9 e 4) populações, respectivamente. Na primavera foram verificadas as menores diversidades nos diferentes pontos de amostragem, com 5, $6 \mathrm{e}$ 5 populações, respectivamente, para o horário de coleta das 14:00 h; e 5, 5 e 3 populações, respectivamente, no horário de coleta das 02:00 h. 


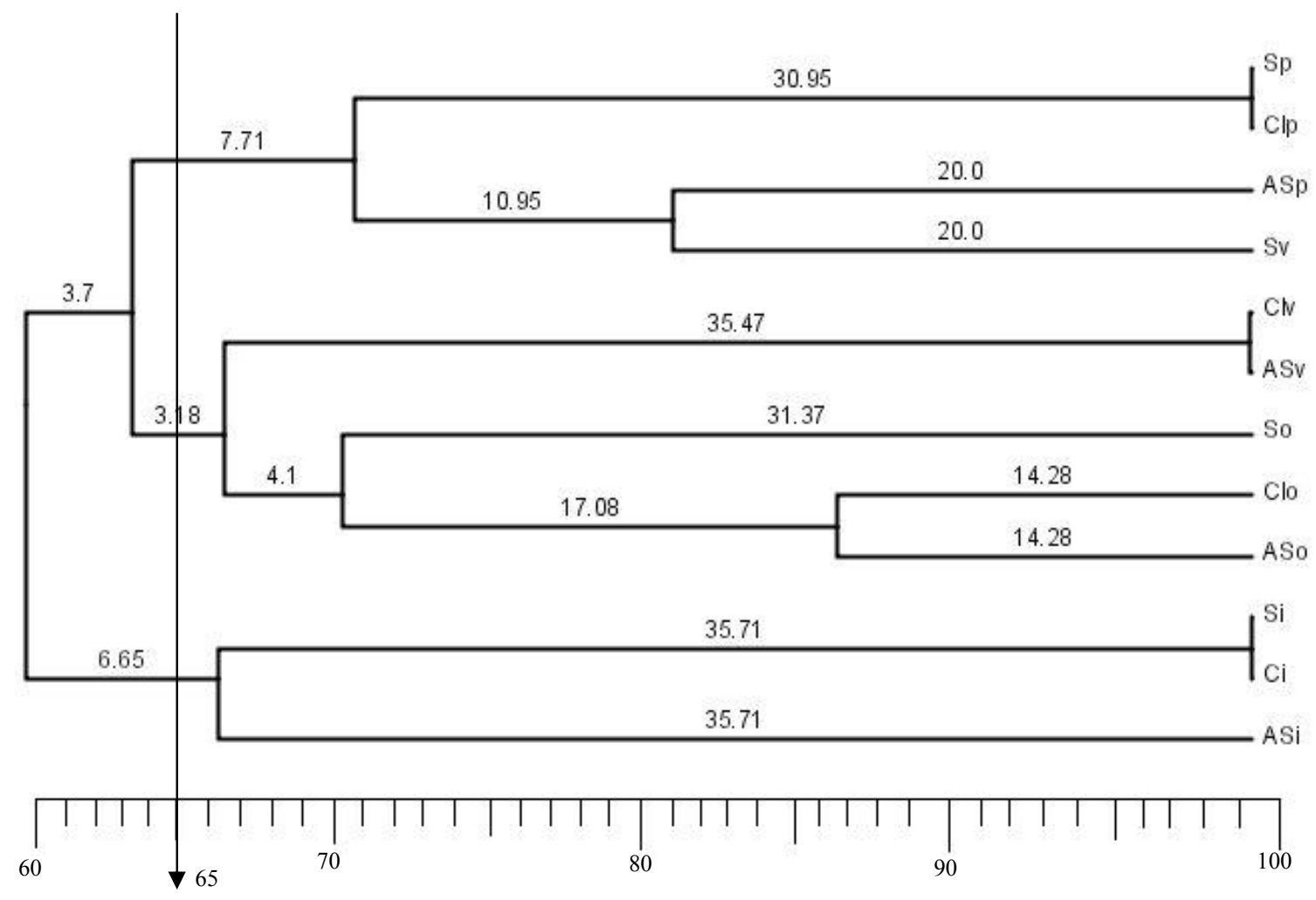

Figura 5.12: Dendrograma das variações sazonais na lagoa anaeróbia com primers para o Domínio Bacteria - 02:00 h (T3)

$\mathrm{S}=$ sub-superfície, $\mathrm{CI}=$ camada intermediária, $\mathrm{AS}=$ interface água-sedimento. A régua indica porcentagens do coeficiente de similaridade

Os valores de $\mathrm{pH}$, temperatura e oxigênio dissolvido na sub-superfície, na primavera, foram de 8,$9 ; 24,5^{\circ} \mathrm{C}$ e $0,1 \mathrm{mg} / \mathrm{L}$, respectivamente. $\mathrm{Na}$ camada intermediária, os valores foram iguais a 8,$9 ; 24,4^{\circ} \mathrm{C}$ e $0,04 \mathrm{mg} / \mathrm{L}$, respectivamente. Com $\mathrm{pH}$ alcalino, temperatura mesofílica e baixa concentração de oxigênio dissolvido, desenvolveram-se populações similares de microrganismos em ambas as camadas. Foram observadas, no perfil de bandas padrões do DGGE, 5 populações semelhantes, em ambos os pontos de coleta, com similaridade de $100 \%$.

Os valores de $\mathrm{pH}$, temperatura e oxigênio dissolvido na camada intermediária, no verão, foram de 9,$1 ; 25,4^{\circ} \mathrm{C}$ e $0,1 \mathrm{mg} / \mathrm{L}$, respectivamente. $\mathrm{Na}$ interface água-sedimento, os valores foram de 9,$0 ; 25,2^{\circ} \mathrm{C}$ e $0,08 \mathrm{mg} / \mathrm{L}$, respectivamente. Esses valores semelhantes 
favoreceram a presença de 9 populações similares, em ambos os pontos de coleta, com $100 \%$ de similaridade.

Os valores de $\mathrm{pH}$, temperatura e oxigênio dissolvido na sub-superfície, no inverno, foram de 8,$5 ; 20,4^{\circ} \mathrm{C}$ e $6,3 \mathrm{mg} / \mathrm{L}$, respectivamente. $\mathrm{Na}$ camada intermediária, os valores foram iguais a 8,$3 ; 19,6^{\circ} \mathrm{C}$ e $0,3 \mathrm{mg} / \mathrm{L}$, respectivamente. Os valores semelhantes de $\mathrm{pH}$ alcalino e temperatura psicrofílica, embora as concentrações de oxigênio dissolvido tenham se apresentado distintas favoreceram o desenvolvimento de populações similares de microrganismos em ambas as camadas. Foram observadas, no perfil de bandas padrões do DGGE, 9 populações similares, em ambas as profundidades, com 100\% de similaridade. Provavelmente, essa elevada similaridade entre as populações foi devido à versatilidade metabólica das bactérias capazes de manterem-se em condições aeróbias (sub-superfície) e anaeróbias (camada intermediária)

Avaliando o perfil de bandas padrões do DGGE realizado com primers para o Domínio Bacteria, no horário das 02:00 h, observou-se na primavera e outono, menor e maior diversidade de bactérias, especificamente na interface água-sedimento, respectivamente. Os valores de $\mathrm{pH}$, temperatura e oxigênio dissolvido na interface águasedimento, no outono, foram de 6,$8 ; 27,1^{\circ} \mathrm{C}$ e $0,04 \mathrm{mg} / \mathrm{L}$, respectivamente. Sob essas condições físico-químicas foi verificada maior diversidade de microrganismos (12 populações). As menores diversidades observadas na primavera (3 populações) foram observadas quando os valores de $\mathrm{pH}$, temperatura e oxigênio dissolvido, na interface águasedimento foram de 8,$9 ; 23,0^{\circ} \mathrm{C}$ e $0,03 \mathrm{mg} / \mathrm{L}$, respectivamente. Esse maior valor de $\mathrm{pH}$ e menor temperatura observados na primavera e outros fatores, possivelmente, contribuíram para a menor diversidade, observada nessa época e horário específico.

Os valores mínimo e máximo de $\mathrm{pH}$ na lagoa anaeróbia, na coleta realizada às 02:00 h, foram de 6,8 no outono e de 9,6 no verão, respectivamente (Figura 5.13). No outono, os valores de $\mathrm{pH}$ foram menores do que os verificados nas outras épocas do ano, e iguais a 6,8 e 7,8 na interface água-sedimento e na sub-superfície, respectivamente. Possivelmente, o pH próximo de neutro favoreceu a maior diversidade de bactérias nessa época, assim como foi verificado também no horário de coleta das 14:00 h (Anexos B1, B7, B13 e B19). O pH afluente variou de 8,7 no verão, a 8,8 na primavera; ou seja, valores superiores aos recomendados por von Sperling (1996), o qual sugere entre 6,7 a 7,5. 


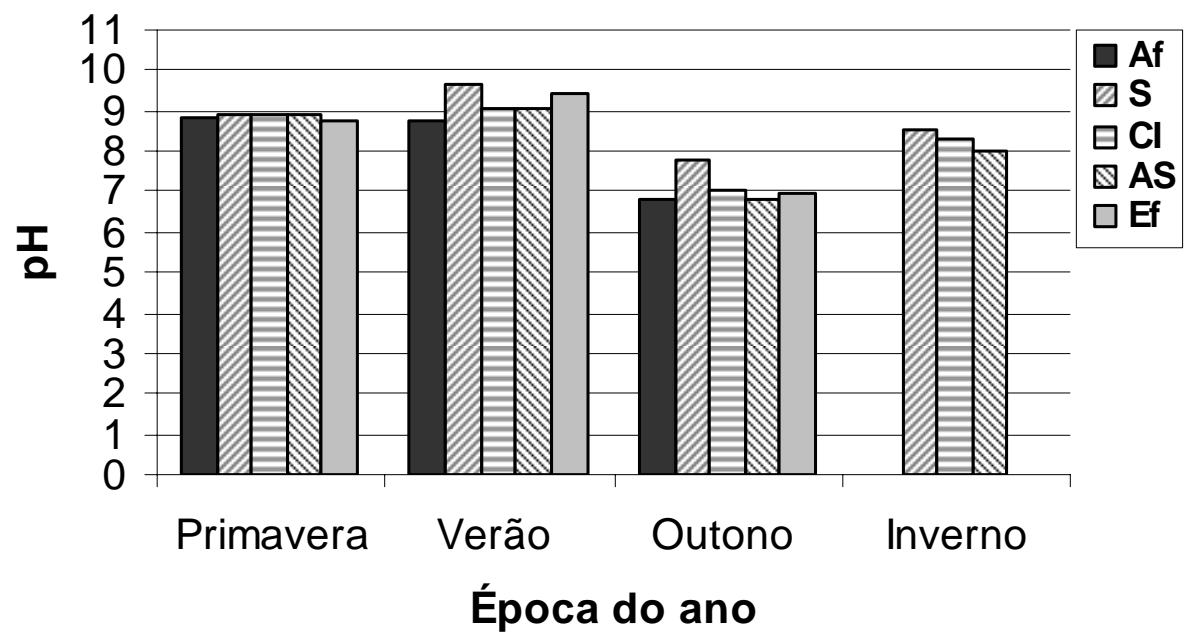

Figura 5.13: Variação sazonal de pH na lagoa anaeróbia referente ao horário T3 (2:00 h) $\mathrm{Af}=$ afluente, $\mathrm{S}=$ sub-superfície, $\mathrm{CI}=$ camada intermediária, $\mathrm{AS}=$ interface água-sedimento, $\mathrm{Ef}=$ efluente

Os valores de temperatura na sub-superfície, camada intermediária e interface águasedimento, na primavera, foram de $24,5^{\circ} \mathrm{C}, 23,4^{\circ} \mathrm{C}$ e $23,0^{\circ} \mathrm{C}$, respectivamente. No outono, os valores foram de $30,5^{\circ} \mathrm{C}, 27,6^{\circ} \mathrm{C}$ e $27,1^{\circ} \mathrm{C}$, respectivamente (Figura 5.14). Assim como foi verificado no horário de coleta das 14:00 h, possivelmente, essa temperatura superior verificada no outono, nas diferentes profundidades, favoreceu o desenvolvimento dos microrganismos nessa época do ano. Os valores de temperatura nas quatro épocas do ano oscilaram de $19,6^{\circ} \mathrm{C}$ no inverno, a $30,5^{\circ} \mathrm{C}$ no outono. A temperatura afluente variou de $23,5^{\circ} \mathrm{C}$ na primavera, a $27,9^{\circ} \mathrm{C}$ no outono. 


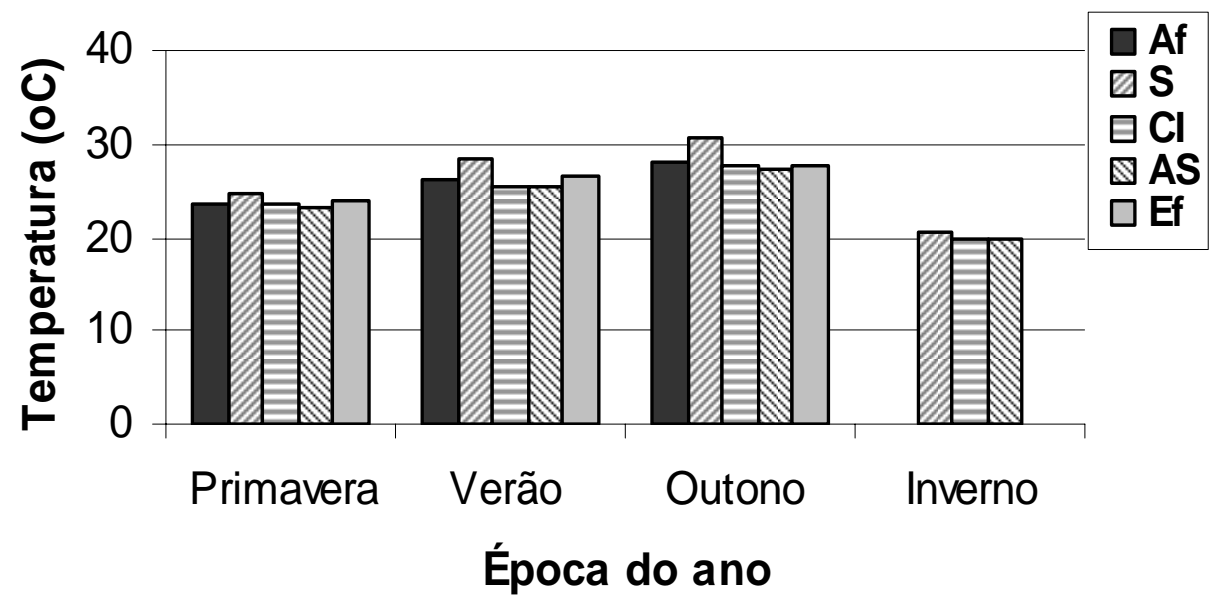

Figura 5.14: Variação sazonal de temperatura na lagoa anaeróbia nas diferentes épocas do ano referente ao horário $\mathrm{T} 3(2: 00 \mathrm{~h})$

$\mathrm{Af}=$ afluente, $\mathrm{S}=$ sub-superfície, $\mathrm{CI}=$ camada intermediária, $\mathrm{AS}=$ interface água-sedimento, $\mathrm{Ef}=$ efluente

As concentrações de oxigênio dissolvido na sub-superfície, camada intermediária e interface água-sedimento, na primavera, foram de $0,13 \mathrm{mg} / \mathrm{L}, 0,04 \mathrm{mg} / \mathrm{L} \mathrm{e} 0,04 \mathrm{mg} / \mathrm{L}$, respectivamente. No outono, os valores foram de $0,14 \mathrm{mg} / \mathrm{L}, 0,04 \mathrm{mg} / \mathrm{L}$ e $0,04 \mathrm{mg} / \mathrm{L}$, respectivamente. Apesar dos valores similares de concentrações de oxigênio dissolvido, foram verificadas diferentes populações nessas estações. As concentrações mínima e máxima de oxigênio dissolvido foram de $0,03 \mathrm{mg} / \mathrm{L}$ na primavera, e $6,3 \mathrm{mg} / \mathrm{L}$ no inverno, respectivamente. No afluente, a concentração variou de $0,5 \mathrm{mg} / \mathrm{L}$ na primavera, a 3,1 $\mathrm{mg} / \mathrm{L}$ no verão (Figura 5.15). Esses resultados indicaram que os maiores valores de oxigênio dissolvido observados no verão, outono e inverno no período de coleta diurno (14:00 horas) foram devido à fotossíntese oxigênica. Em contrapartida, esses valores foram menores no período noturno devido, provavelmente, à maior taxa de respiração em relação à fotossíntese. Todavia, um valor ligeiramente maior foi observado no inverno $(6,34 \mathrm{mg} / \mathrm{L})$, favorecido, provavelmente, pela sua maior solubilização em temperaturas mais baixas $\left(20,5^{\circ} \mathrm{C}\right)$. 


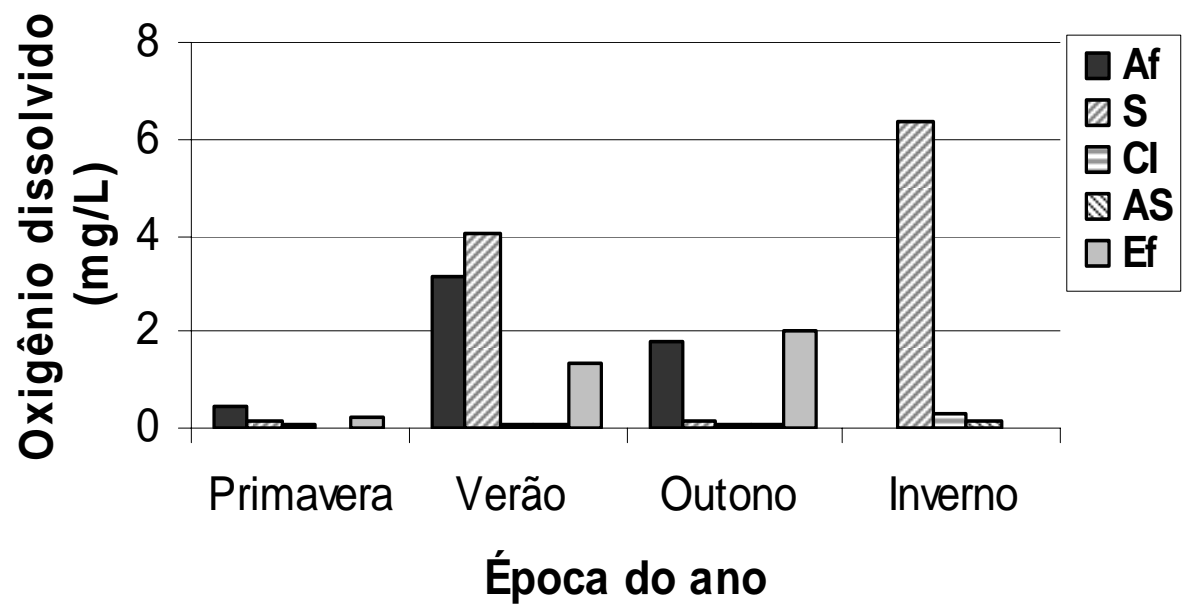

Figura 5.15: Variações sazonais de oxigênio dissolvido na lagoa anaeróbia referente ao horário T3 $(02: 00 \mathrm{~h})$

$\mathrm{Af}=$ afluente, $\mathrm{S}=$ sub-superfície, $\mathrm{CI}=$ camada intermediária, $\mathrm{AS}$ = interface água-sedimento, $\mathrm{Ef}=$ efluente

As concentrações de sulfato na sub-superfície, camada intermediária e interface água-sedimento, na primavera, foram de $28,0 \mathrm{mg} / \mathrm{L}, 23,0 \mathrm{mg} / \mathrm{L}$ e $18,0 \mathrm{mg} / \mathrm{L}$, respectivamente. No outono, os valores foram de $17,0 \mathrm{mg} / \mathrm{L}, 15,0 \mathrm{mg} / \mathrm{L}$ e 11,0 mg/L, respectivamente (Figura 5.16). As concentrações mínima e máxima de sulfato foram de $11,0 \mathrm{mg} / \mathrm{L}$ no outono, e 51,0 mg/L no inverno. No afluente, as concentrações variaram de $32,0 \mathrm{mg} / \mathrm{L}$ no verão, a $63,0 \mathrm{mg} / \mathrm{L}$ na primavera. Esses valores foram próximos aos observados no horário T1 (14:00 h) e, portanto, observa-se que o metabolismo assimilativo de enxofre foi favorecido, também, no horário T3 $(2: 00 \mathrm{~h})$.

As concentrações de oxigênio dissolvido verificadas na sub-superfície, camada intermediária e interface água-sedimento, na primavera e outono, variaram de $0,04 \mathrm{mg} / \mathrm{L} \mathrm{a}$ $0,14 \mathrm{mg} / \mathrm{L}$, respectivamente. Os valores de temperatura oscilaram de $23,1^{\circ} \mathrm{C}$ na primavera, a $30,5^{\circ} \mathrm{C}$ no outono. 


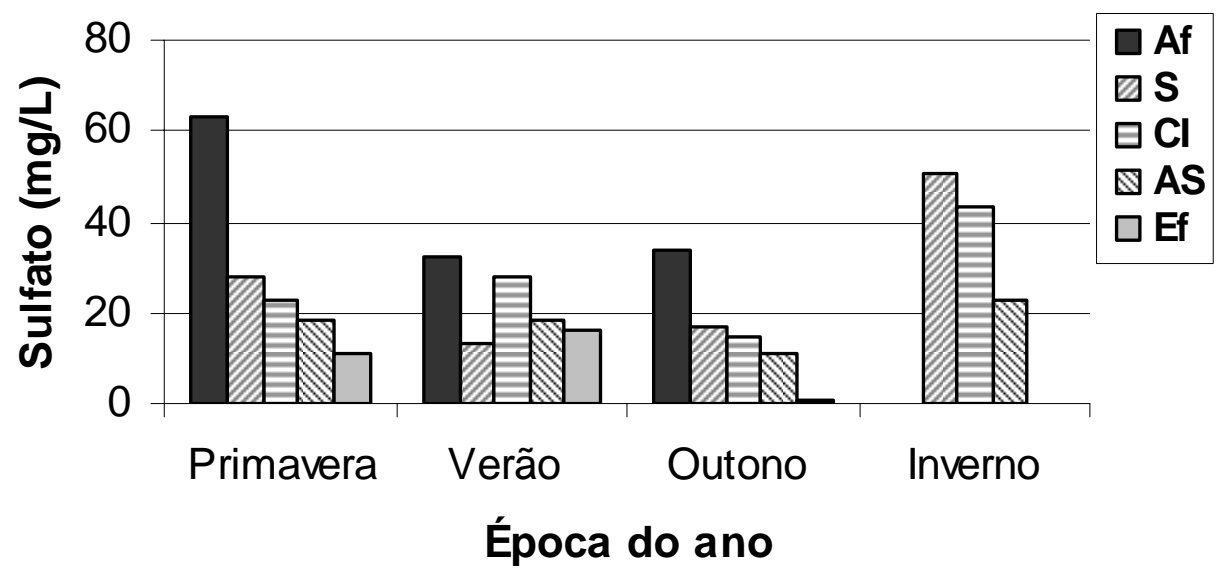

Figura 5.16: Variações sazonais de sulfato na lagoa anaeróbia referente ao horário T3 (2:00 h) $\mathrm{Af}=$ afluente, $\mathrm{S}=$ sub-superfície, $\mathrm{CI}=$ camada intermediária, $\mathrm{AS}=$ interface água-sedimento, $\mathrm{Ef}=$ efluente

As concentrações de matéria orgânica bruta $\left(\mathrm{DQO}_{\mathrm{b}}\right)$ na sub-superfície, camada intermediária e interface água-sedimento, na primavera, foram de 77,0 mg/L, 120,0 mg/L e $102,0 \mathrm{mg} / \mathrm{L}$, respectivamente. No outono, os valores foram de 144,5 mg/L, 148,1 mg/L e 132,6 mg/L, respectivamente (Figura 5.17). A $\mathrm{DQO}_{\mathrm{b}}$, nas diferentes épocas do ano, variou de $77,0 \mathrm{mg} / \mathrm{L}$ na primavera, a $251,7 \mathrm{mg} / \mathrm{L}$ no inverno. No afluente, esta variou de 88,0 $\mathrm{mg} / \mathrm{L}$ no verão, a $268,6 \mathrm{mg} / \mathrm{L}$ no outono. Portanto, foram valores inferiores aos observados para lagoas de estabilização utilizadas no tratamento de esgoto sanitário.

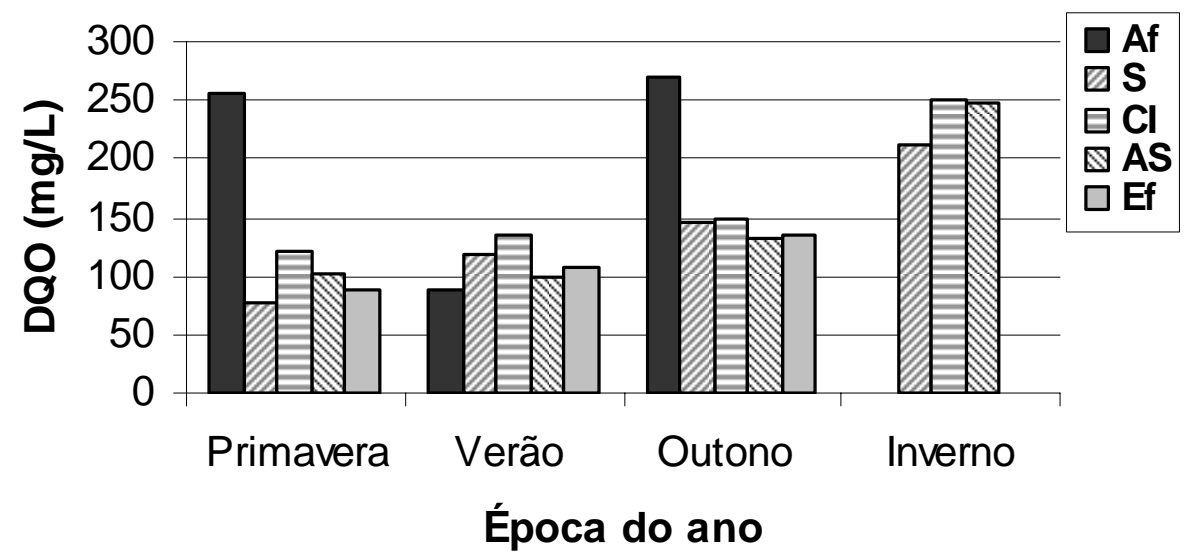

5.17: Variações sazonais da matéria orgânica na lagoa anaeróbia referente ao horário T3 (2:00 h) $\mathrm{Af}=$ afluente, $\mathrm{S}=$ sub-superfície, $\mathrm{CI}=$ camada intermediária, $\mathrm{AS}=$ interface água-sedimento, $\mathrm{Ef}=$ efluente 
As concentrações de sólidos suspensos voláteis na sub-superfície, camada intermediária e interface água-sedimento, na primavera, foram de 120,0 mg/L, 86,0 mg/L e $126,0 \mathrm{mg} / \mathrm{L}$, respectivamente. No outono, os valores foram de 47,0 mg/L, 117,0 mg/L e $137,0 \mathrm{mg} / \mathrm{L}$, respectivamente. Somente na sub-superfície, na primavera, foi verificado maior valor que o observado no outono. Na camada intermediária e na interface águasedimento, no outono, foram verificados valores superiores aos observados na primavera. Possivelmente, isto reflita maior diversidade verificada nesses pontos de coleta e época do ano. As concentrações mínima e máxima foram de 37,0 mg/L no inverno, e 137,0 mg/L no outono, respectivamente, sendo valores próximos aos verificados no horário de coleta $\mathrm{T} 1$. No afluente, variou de $0,0 \mathrm{mg} / \mathrm{L}$ no outono, a 93,0 $\mathrm{mg} / \mathrm{L}$ na primavera, que foram valores menores aos verificados no horário T1 (Figura 5.18).

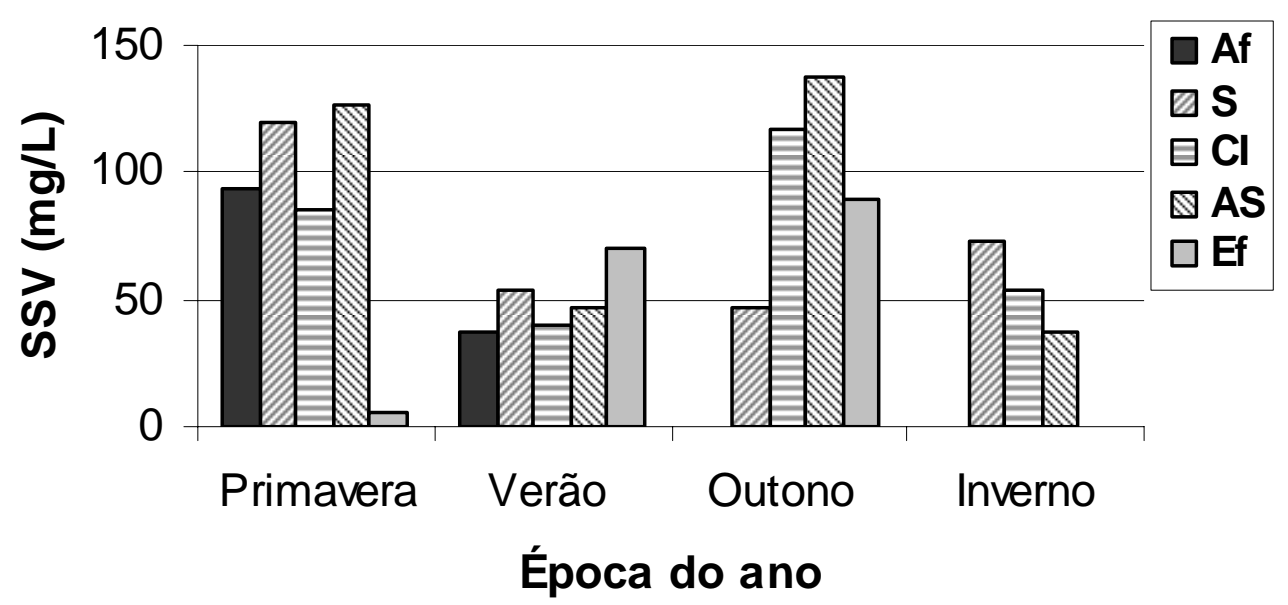

Figura 5.18: Variações sazonais de SSV na lagoa anaeróbia referente ao horário T3 (2:00 h) $\mathrm{Af}=$ afluente, $\mathrm{S}=$ sub-superfície, $\mathrm{CI}=$ camada intermediária, $\mathrm{AS}=$ interface água-sedimento, $\mathrm{Ef}=$ efluente

As concentrações de NTK na sub-superfície, camada intermediária e interface águasedimento, na primavera, foram de $26,5 \mathrm{mg} / \mathrm{L}, 26,1 \mathrm{mg} / \mathrm{L}$ e $27,7 \mathrm{mg} / \mathrm{L}$, respectivamente. No outono, os valores foram de 13,6 mg/L, 15,2 mg/L e 21,0 mg/L, respectivamente. A concentração mínima foi de $8,6 \mathrm{mg} / \mathrm{L}$ no verão, e máxima de $27,5 \mathrm{mg} / \mathrm{L}$ na primavera (Figura 5.19). No afluente, variou de $17,2 \mathrm{mg} / \mathrm{L}$ no verão, a $33,5 \mathrm{mg} / \mathrm{L}$ no outono. As concentrações de nitrato na sub-superfície, camada intermediária e interface água- 
sedimento, na primavera, foram de 1,5 mg/L, 1,6 mg/L e 1,5 mg/L, respectivamente. No outono, os valores foram iguais a 2,6 mg/L, 2,9 mg/L e 2,6 mg/L, respectivamente. As concentrações de nitrito, na sub-superfície, camada intermediária e interface águasedimento, na primavera, foram de $4,0 \mu \mathrm{g} / \mathrm{L}, 3,7 \mu \mathrm{g} / \mathrm{L}$ e $4,7 \mu \mathrm{g} / \mathrm{L}$, respectivamente. No outono, os valores foram iguais a $3,8 \mu \mathrm{g} / \mathrm{L}, 4,8 \mu \mathrm{g} / \mathrm{L}$ e $4,3 \mu \mathrm{g} / \mathrm{L}$, respectivamente. Em geral, as concentrações de NTK, nitrito e nitrato foram maiores no horário de coleta T1, nas diferentes épocas do ano e diferentes profundidades.

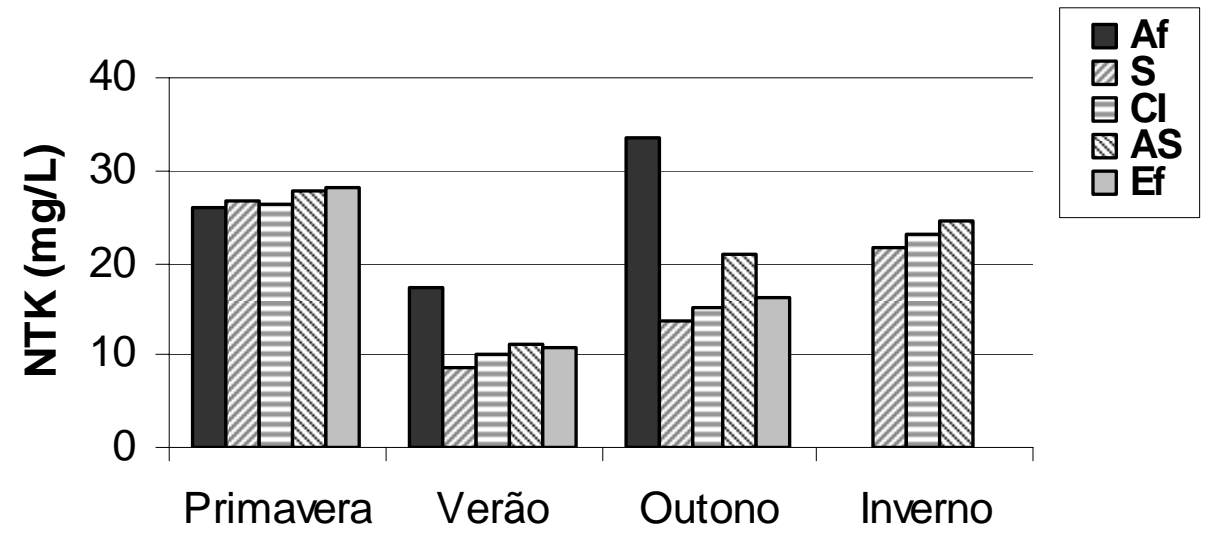

\section{Época do ano}

Figura 5.19: Variações sazonais de NTK na lagoa anaeróbia referente ao horário T3 (2:00 h) Af $=$ afluente, $\mathrm{S}=$ sub-superfície, $\mathrm{CI}=$ camada intermediária, $\mathrm{AS}=$ interface água-sedimento, $\mathrm{Ef}=$ efluente

As concentrações de fósforo total (PT) na sub-superfície, camada intermediária e interface água-sedimento, na primavera, foram de 3,6 mg/L, 2,7 mg/L e 5,2 $\mathrm{mg} / \mathrm{L}$, respectivamente. No outono, os valores foram de $3,9 \mathrm{mg} / \mathrm{L}, 4,0 \mathrm{mg} / \mathrm{L}$ e $0,3 \mathrm{mg} / \mathrm{L}$, respectivamente. Concentrações mínima e máxima foram de $0,3 \mathrm{mg} / \mathrm{L}$ no outono, e 5,2 $\mathrm{mg} / \mathrm{L}$ na primavera. No afluente, variou de $0,6 \mathrm{mg} / \mathrm{L}$ no verão a 7,0 $\mathrm{mg} / \mathrm{L}$ na primavera (Figura 5.20). Os valores de fósforo total foram similares aos observados no horário T1.

As concentrações de ortofosfato na sub-superfície, camada intermediária e interface água-sedimento, na primavera, foram de $1,8 \mathrm{mg} / \mathrm{L}, 2,5 \mathrm{mg} / \mathrm{L}$ e $2,1 \mathrm{mg} / \mathrm{L}$, respectivamente. No outono, os valores foram iguais a $1,6 \mathrm{mg} / \mathrm{L}, 2,3 \mathrm{mg} / \mathrm{L}$ e $2,7 \mathrm{mg} / \mathrm{L}$, respectivamente. As 
concentrações de fósforo total dissolvido na sub-superfície, camada intermediária e interface água-sedimento, na primavera, foram de $3,0 \mathrm{mg} / \mathrm{L}, 3,2 \mathrm{mg} / \mathrm{L}$ e $3,8 \mathrm{mg} / \mathrm{L}$, respectivamente. No outono, os valores foram iguais a 2,3 mg/L, 2,9 mg/L e 2,8 mg/L, respectivamente. Essas concentrações de ortofosfato foram superiores aos verificados no horário de coleta $\mathrm{T} 1$.

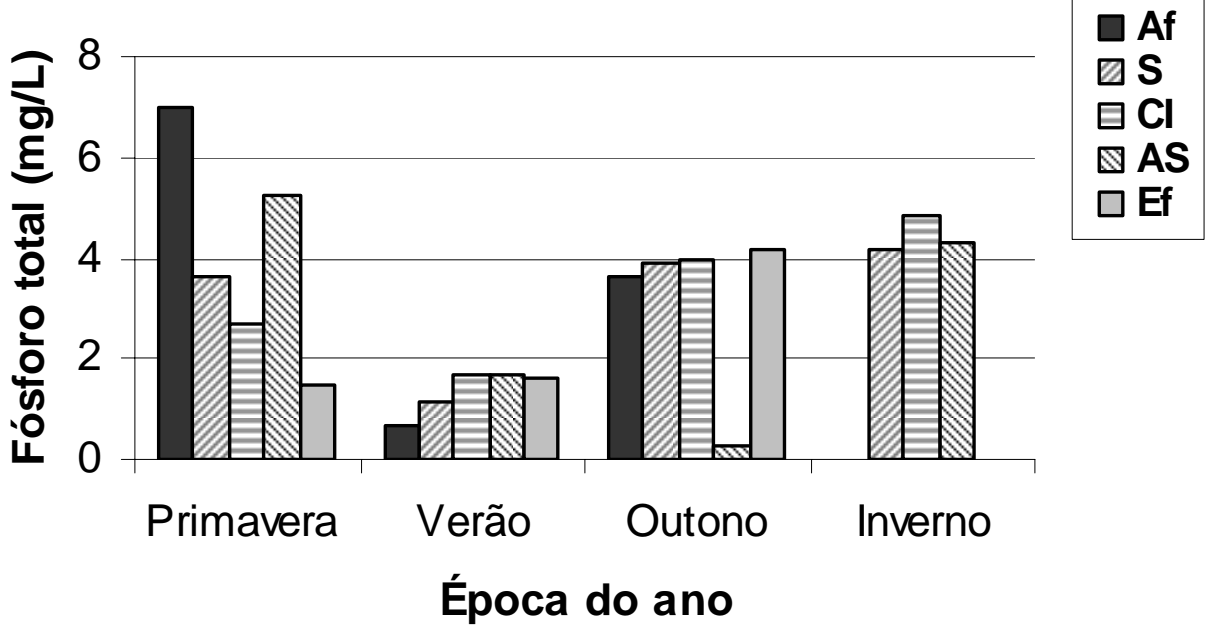

Figura 5.20: Variações sazonais de fósforo total na lagoa anaeróbia referente ao horário T3 (02:00 h)

$\mathrm{Af}=$ afluente, $\mathrm{S}=$ sub-superfície, $\mathrm{CI}=$ camada intermediária, $\mathrm{AS}=$ interface água-sedimento, $\mathrm{Ef}=$ efluente 


\subsubsection{Diversidade das bactérias fototróficas púrpuras}

A partir do DGGE realizado com primers pufM.557FGC e 750R, de amostra da lagoa anaeróbia coletada às 14:00 h (T1), foi elaborado o dendrograma da Figura 5.21. Corte arbitrário de $65 \%$ de similaridade foi realizado, sendo possível observar três agrupamentos principais. O primeiro agrupamento relacionou, com $100 \%$ de similaridade, a distribuição dos microrganismos na sub-superfície e camada intermediária, na primavera; assim como na sub-superfície e camada intermediária, no inverno. O segundo agrupamento relacionou, com 100\% de similaridade, a distribuição dos microrganismos na camada intermediária e na interface água-sedimento, no verão.

A distribuição na sub-superfície e camada intermediária, na primavera, foi $75 \%$ similar à observada na sub-superfície, no verão. A distribuição na sub-superfície e camada intermediária, no inverno, foi similar em $80 \%$ com a da interface água-sedimento, na mesma época do ano. A distribuição na camada intermediária e interface água-sedimento, no verão, foi similar em $84 \%$ à verificada na interface água-sedimento, na primavera. $\mathrm{O}$ terceiro agrupamento relacionou a distribuição dos microrganismos no outono, apresentando similaridade de $95 \%$ para a camada intermediária e a interface águasedimento.

A radiação solar fotossinteticamente ativa incidente no horário de coleta das 14:00

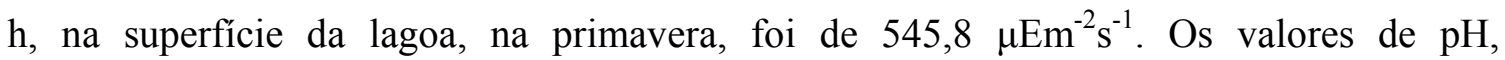
temperatura e oxigênio dissolvido na sub-superfície, foram de 9,$6 ; 23,4^{\circ} \mathrm{C}$ e $0,7 \mathrm{mg} / \mathrm{L}$, respectivamente. Na camada intermediária, os valores foram de 8,$9 ; 22,9^{\circ} \mathrm{C}$ e $0,05 \mathrm{mg} / \mathrm{L}$, respectivamente. Valores de $\mathrm{pH}$ alcalino, temperatura mesofílica e baixa concentração de oxigênio dissolvido permitiram o desenvolvimento de populações similares de bactérias fototróficas púrpuras (4 bandas, respectivamente), com similaridade de 100\%. 


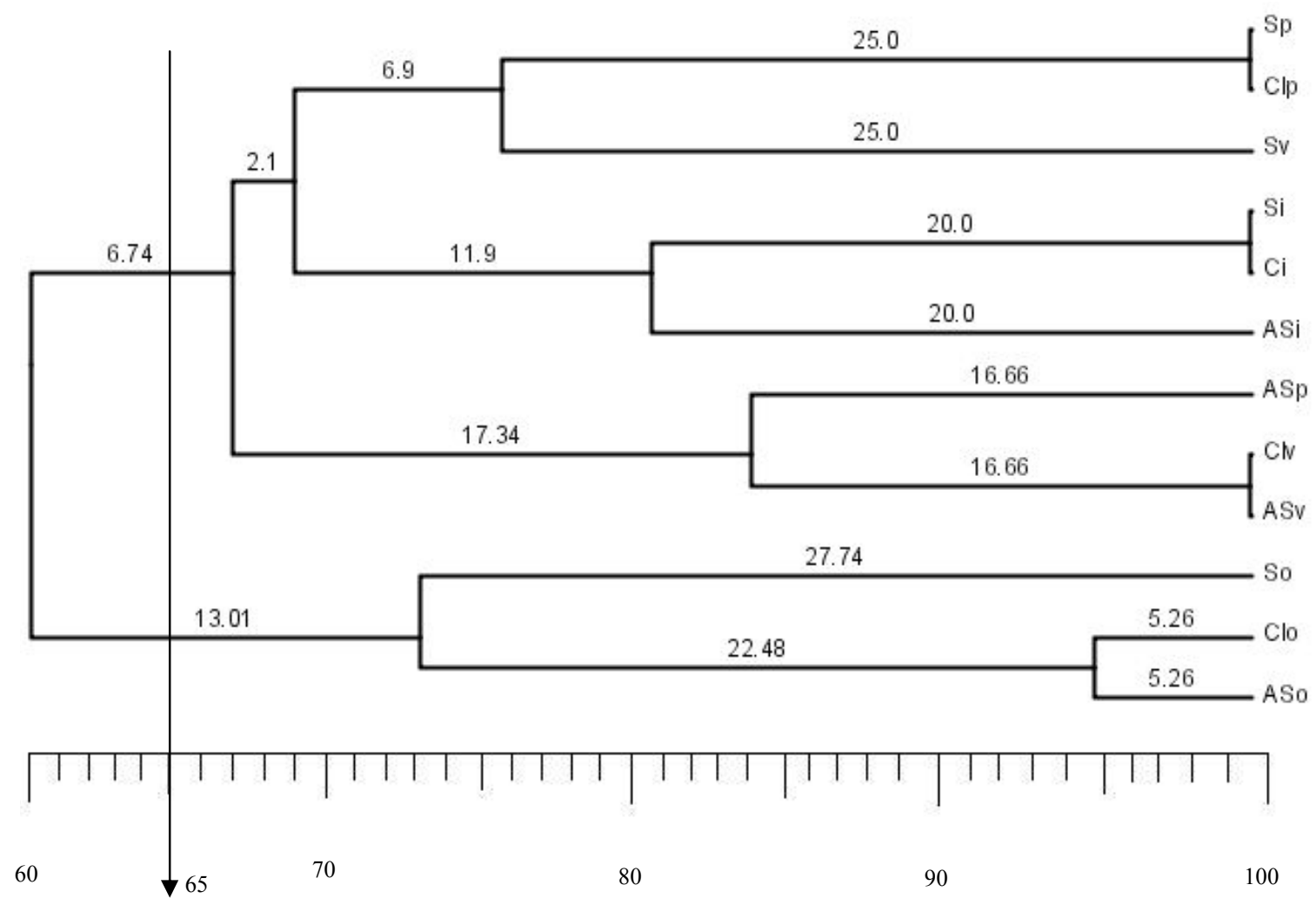

Figura 5.21: Dendrograma das variações sazonais na lagoa anaeróbia com primers pufM referente

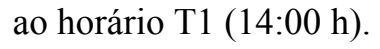

$\mathrm{S}=$ sub-superfície, $\mathrm{CI}=$ camada intermediária, $\mathrm{AS}=$ interface água-sedimento. A régua indica porcentagens do coeficiente de similaridade

A radiação solar fotossinteticamente ativa incidente na superfície da lagoa, no inverno, foi de $574,8 \mu \mathrm{Em}^{-2} \mathrm{~s}^{-1}$. Os valores de $\mathrm{pH}$, temperatura e oxigênio dissolvido na subsuperfície foram de 9,$4 ; 26,9^{\circ} \mathrm{C}$ e $8,2 \mathrm{mg} / \mathrm{L}$, respectivamente. Na camada intermediária, os valores foram de 8,$9 ; 19,6^{\circ} \mathrm{C}$ e $1,6 \mathrm{mg} / \mathrm{L}$, respectivamente. Essas condições físico-químicas favoreceram o desenvolvimento de populações similares de bactérias fototróficas púrpuras, em ambas as profundidades ( 7 bandas, respectivamente), com $100 \%$ de similaridade.

Os valores de $\mathrm{pH}$, temperatura e oxigênio dissolvido na camada intermediária, no verão, foram de 9,$2 ; 25,9^{\circ} \mathrm{C}$ e $0,1 \mathrm{mg} / \mathrm{L}$, respectivamente. $\mathrm{Na}$ interface água-sedimento, os valores foram de 9,$2 ; 25,2^{\circ} \mathrm{C}$ e $0,08 \mathrm{mg} / \mathrm{L}$, respectivamente. Sob essas condições físicoquímicas semelhantes, foram verificadas populações similares de bactérias fototróficas púrpuras (10 bandas), em ambas as profundidades, com 100\% de similaridade. 
No outono foi verificado, para o horário de coleta das 14:00 h, maior diversidade de bactérias fototróficas púrpuras, principalmente na camada intermediária e na interface água-sedimento com 17 e 18 populações, respectivamente. Os valores de $\mathrm{pH}$, temperatura e oxigênio dissolvido na camada intermediária, no outono, foram de 7,$1 ; 26,5^{\circ} \mathrm{C}$ e $0,0 \mathrm{mg} / \mathrm{L}$, respectivamente. $\mathrm{Na}$ interface água-sedimento, os valores foram de 7,$0 ; 26,2^{\circ} \mathrm{C}$ e $0,0 \mathrm{mg} / \mathrm{L}$, respectivamente. $\mathrm{O}$ pH neutro, a temperatura mesofílica e a ausência de oxigênio dissolvido favoreceram a maior diversidade de bactérias fototróficas púrpuras nas duas profundidades. Valores superiores de $\mathrm{pH}$, temperatura e oxigênio dissolvido obtidos na sub-superfície, no outono, iguais a 9,$1 ; 35,1^{\circ} \mathrm{C}$ e $8,2 \mathrm{mg} / \mathrm{L}$, respectivamente, contribuíram para o menor desenvolvimento das bactérias fototróficas púrpuras (14 bandas), selecionando apenas algumas populações e possibilitando o crescimento de outras nas camadas mais profundas da lagoa.

A partir do DGGE realizado com primers pufM.557FGC e 750R, de amostra da lagoa anaeróbia coletada às 02:00 h (T3), foi elaborado o dendrograma da Figura 5.22. Corte arbitrário de $65 \%$ de similaridade foi realizado, sendo possível observar dois agrupamentos principais. $\mathrm{O}$ primeiro agrupamento relacionou a distribuição dos microrganismos na primavera, a qual foi similar nos três pontos de amostragem $(100 \%$ de similaridade); assim como na camada intermediária e interface água-sedimento, no verão, e na interface água-sedimento, no outono. No segundo agrupamento foi verificado, também, $100 \%$ de similaridade na sub-superfície, no verão, e camada intermediária, no outono. A sub-superfície e a interface água-sedimento, no inverno, apresentaram 77\% de similaridade.

Os valores de $\mathrm{pH}$, temperatura e oxigênio dissolvido na sub-superfície, na primavera, foram de 8,$9 ; 24,5^{\circ} \mathrm{C}$ e $0,14 \mathrm{mg} / \mathrm{L}$, respectivamente. Na camada intermediária, os valores foram de 8,$9 ; 24,4^{\circ} \mathrm{C}$ e $0,04 \mathrm{mg} / \mathrm{L}$, respectivamente. $\mathrm{Na}$ interface águasedimento, os valores foram de 8,$9 ; 23,0^{\circ} \mathrm{C}$ e $0,03 \mathrm{mg} / \mathrm{L}$, respectivamente. Nessas condições mencionadas anteriormente, estabelecidas pelos parâmetros físico-químicos próximos, desenvolveram-se populações similares de bactérias fototróficas púrpuras nas diferentes profundidades ( 2 bandas). 


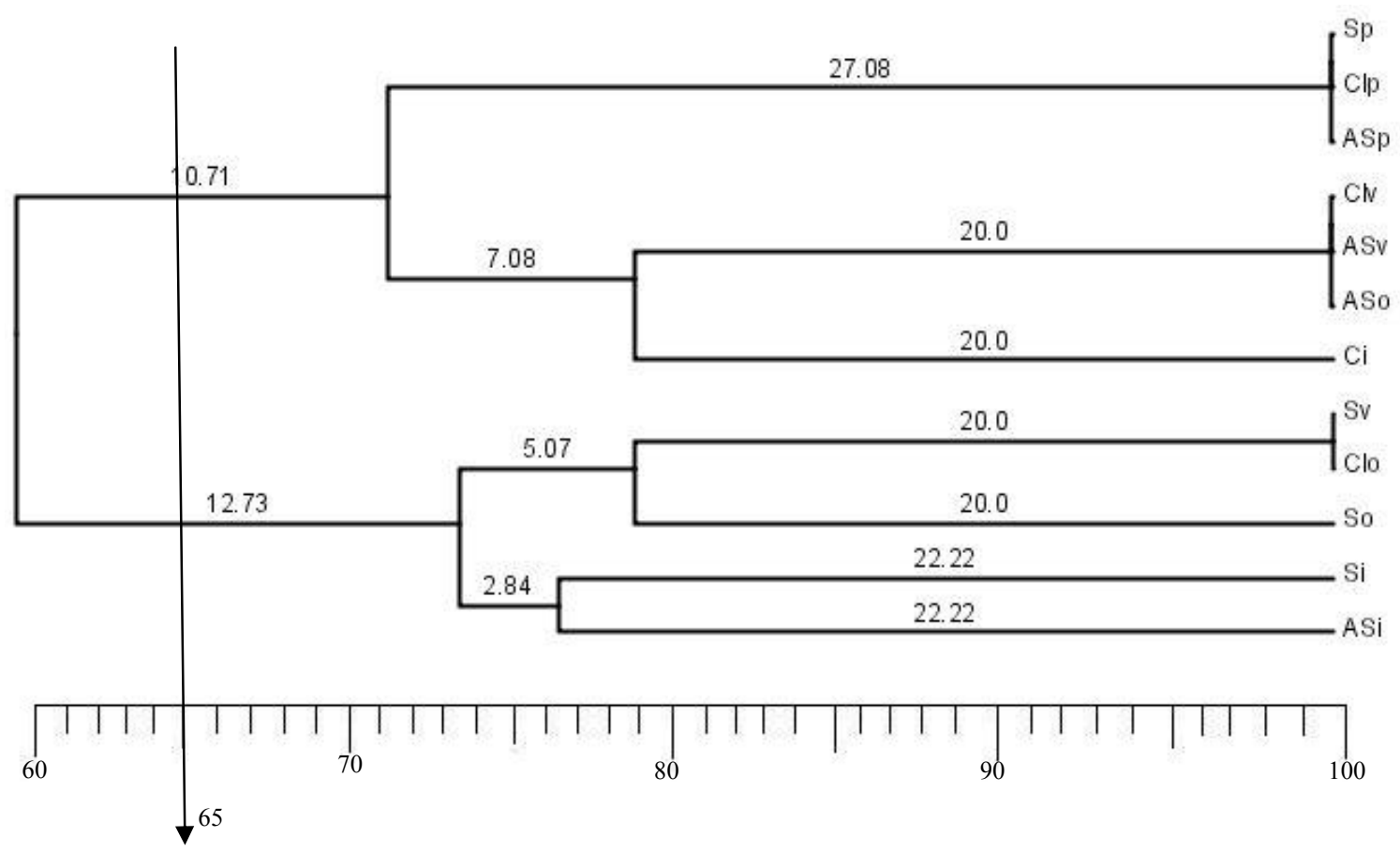

Figura 5.22: Dendrograma das variações sazonais na lagoa anaeróbia com primers puf $\mathrm{M}$ referente ao horário $\mathrm{T} 3(02: 00 \mathrm{~h})$.

$\mathrm{S}=$ sub-superfície, $\mathrm{CI}=$ camada intermediária, $\mathrm{AS}=$ interface água-sedimento. A régua indica porcentagens do coeficiente de similaridade

Os valores de $\mathrm{pH}$, temperatura e oxigênio dissolvido na camada intermediária, no verão, foram de 9,$1 ; 25,4^{\circ} \mathrm{C}$ e $0,1 \mathrm{mg} / \mathrm{L}$, respectivamente. Na interface água-sedimento, os valores foram de 9,$0 ; 25,2^{\circ} \mathrm{C}$ e $0,08 \mathrm{mg} / \mathrm{L}$, respectivamente. $\mathrm{Na}$ interface água-sedimento, no outono, os valores foram iguais a 6,$8 ; 27,1^{\circ} \mathrm{C}$ e $0,04 \mathrm{mg} / \mathrm{L}$, respectivamente. Apesar de ter sido observado menor $\mathrm{pH}$ e maior temperatura no outono, foram favorecidas populações similares de bactérias fototróficas púrpuras nesses pontos de amostragem época do ano (3 bandas, respectivamente).

Os valores de $\mathrm{pH}$, temperatura e oxigênio dissolvido na sub-superfície, no verão, foram de 9,$6 ; 28,3^{\circ} \mathrm{C}$ e $4,0 \mathrm{mg} / \mathrm{L}$, respectivamente. Na camada intermediária, no outono, os valores foram de 7,$0 ; 27,6^{\circ} \mathrm{C}$ e $0,04 \mathrm{mg} / \mathrm{L}$, respectivamente. Independentemente do valor de pH e da concentração de oxigênio dissolvido terem sido maiores no verão, foram verificadas populações similares de bactérias fototróficas púrpuras nessas profundidades, e épocas do ano ( 6 bandas, respectivamente). 
No horário de coleta das 02:00 h, os perfis das bandas padrões no DGGE indicaram diminuição no número de populações de bactérias fototróficas púrpuras na primavera, verão, outono e inverno, para todos os pontos amostrados, quando comparado aos resultados obtidos às 14:00 h. Na primavera, no horário das 14:00 h, foram verificadas na sub-superfície, camada intermediária e interface água-sedimento 4,4 e 8 bandas, respectivamente, números superiores aos verificados no horário das 02:00 h, com 2, 2 e 2 bandas similares, respectivamente. A maior diferença na quantidade de bandas foi verificada no outono, que de 14, 17 e 18 bandas (14:00 h), respectivamente, diminuíram para 8,6 e 3 bandas $(02: 00$ h), respectivamente. Provavelmente, as bactérias que crescem heterotroficamente no escuro se mantiveram na lagoa. Todavia, as outras, que possuem metabolismo fotoautotrófico e fotoheterotrófico foram desfavorecidas ou ter acontecido predação por microrganismos tais como os protozoários. Além disso, segundo Amann et al. (1995), a técnica de PCR/DGGE só permite observar populações presentes em concentrações superiores a $10^{4}$ células $/ \mathrm{mL}$. Desse modo, provavelmente, algumas populações mantiveram-se na lagoa, todavia, com valores inferiores a esse e, portanto, não foram detectadas pela técnica. Também, possivelmente, algumas bactérias tenham migrado para o sedimento da lagoa.

Maior diversidade de bactérias fototróficas púrpuras foi observada na coleta realizada no outono, assim como foi verificado para o Domínio Bacteria. Duas populações de bactérias fototróficas púrpuras predominantes foram observadas na lagoa anaeróbia, nas quatro estações do ano, independente dos horários de coletas (período diurno ou noturno), dos parâmetros físico-químicos, e dos pontos de amostragem. 


\subsubsection{Diversidade das bactérias redutoras de sulfato}

Cabe ressaltar que as amostras da primavera (outubro de 2004) não foram amplificadas no respectivo PCR, devido, possivelmente, à ausência de células ou à concentração inferior a $10^{4}$ células/mL nessa época do ano, na lagoa de estabilização (AMANN et al., 1995).

A partir do DGGE realizado com primers para as BRS, de amostra da lagoa anaeróbia coletada às 14:00 h (T1), foi elaborado o dendrograma da Figura 5.23. Corte arbitrário de $65 \%$ de similaridade foi realizado, sendo possível observar três agrupamentos principais. No primeiro agrupamento, um coeficiente de similaridade de $100 \%$ foi obtido para a sub-superfície, camada intermediária e interface água-sedimento, no verão. Similaridade de $70 \%$ foi verificada na sub-superfície e camada intermediária, no inverno. No segundo agrupamento foi obtido no outono, um coeficiente de similaridade de $92 \%$ na camada intermediária e interface água-sedimento. O terceiro agrupamento relacionou-se com os anteriores agrupamentos com $60 \%$ de similaridade, e correspondeu à distribuição dos microrganismos na interface água-sedimento da lagoa, no inverno.

A radiação solar fotossinteticamente ativa incidente na superfície da lagoa, no verão, foi de $245,5 \mu \mathrm{Em}^{-2} \mathrm{~s}^{-1}$. Na sub-superfície, o $\mathrm{pH}$ foi de 10,9; a temperatura foi de $33,0^{\circ} \mathrm{C}$ e o oxigênio dissolvido foi de $7,4 \mathrm{mg} / \mathrm{L}$. Os valores de $\mathrm{pH}$, temperatura e oxigênio dissolvido na camada intermediária foram de 9,$2 ; 25,9^{\circ} \mathrm{C}$ e $0,1 \mathrm{mg} / \mathrm{L}$, respectivamente. $\mathrm{Na}$ interface água-sedimento, os valores foram de 9,$2 ; 25,2^{\circ} \mathrm{C}$ e $0,08 \mathrm{mg} / \mathrm{L}$, respectivamente. Apesar de ter sido observado valores superiores dos parâmetros físico-químicos na subsuperfície, foram verificadas populações similares de bactérias redutoras de sulfato nas três profundidades ( 3 bandas, respectivamente). 


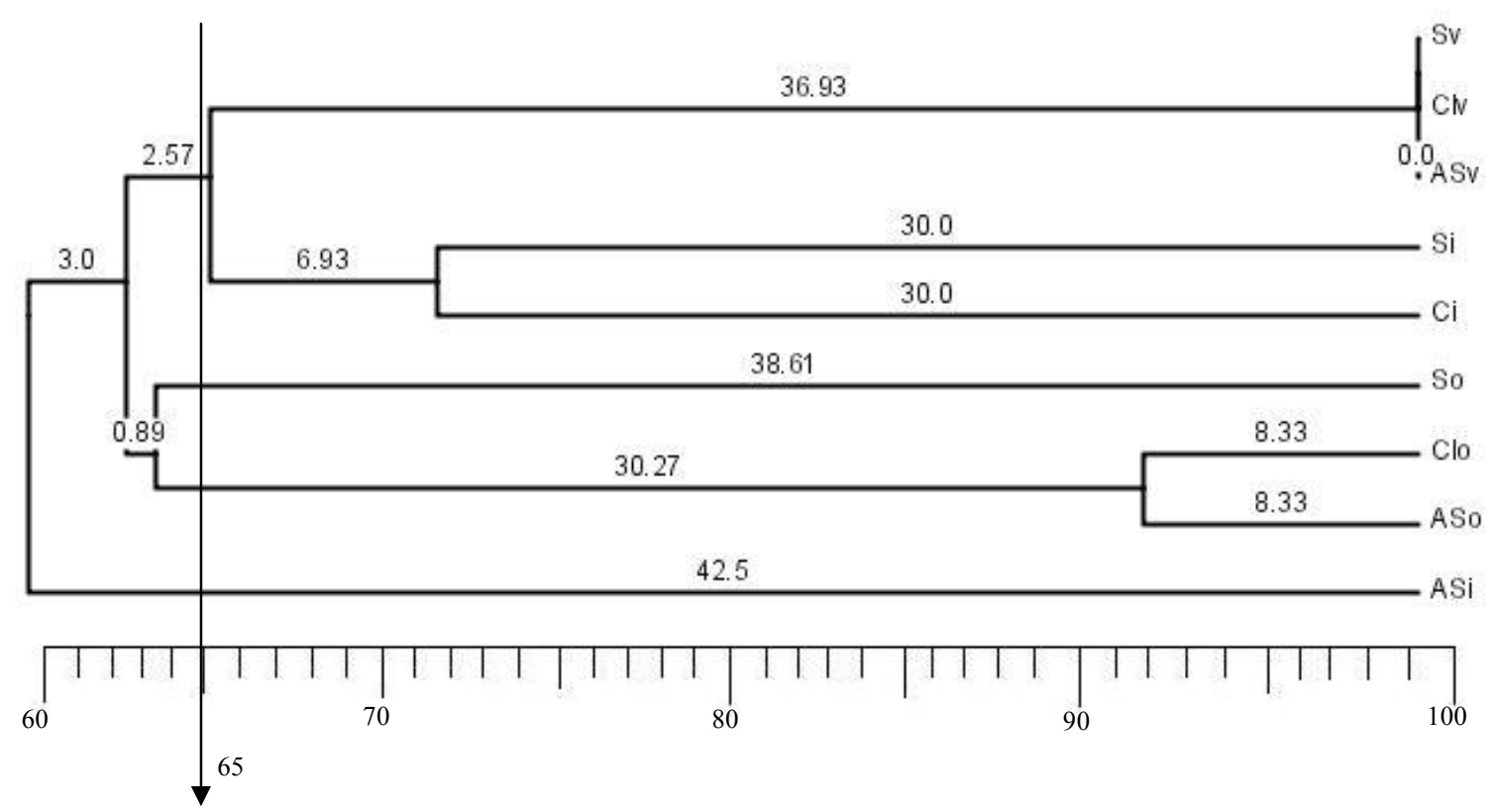

Figura 5.23: Dendrograma das variações sazonais na lagoa anaeróbia com primers para as BRS referente ao horário T1 (14:00 h).

$\mathrm{S}=$ sub-superfície, $\mathrm{CI}=$ camada intermediária, $\mathrm{AS}=$ interface água-sedimento. A régua indica porcentagens do coeficiente de similaridade

Os valores de $\mathrm{pH}$, temperatura e oxigênio dissolvido na sub-superfície, no inverno, foram de 9,$4 ; 26,9^{\circ} \mathrm{C}$ e $8,2 \mathrm{mg} / \mathrm{L}$, respectivamente. $\mathrm{Na}$ camada intermediária, os valores foram de 8,$9 ; 19,6^{\circ} \mathrm{C}$ e $1,6 \mathrm{mg} / \mathrm{L}$, respectivamente. Ambas as profundidades apresentaram $70 \%$ de similaridade, com a presença de 7 e 4 bandas, respectivamente.

Os valores de $\mathrm{pH}$, temperatura e oxigênio dissolvido na camada intermediária, no outono, foram de 7,$1 ; 26,5^{\circ} \mathrm{C}$ e $0,0 \mathrm{mg} / \mathrm{L}$, respectivamente. Na interface água-sedimento, os valores foram de 7,$0 ; 26,2^{\circ} \mathrm{C}$ e $0,0 \mathrm{mg} / \mathrm{L}$, respectivamente. Com $\mathrm{pH}$ neutro, temperatura mesofílica e ausência de oxigênio desenvolveram-se populações semelhantes de BRS na camada intermediária (10 bandas) e na interface água-sedimento (11 bandas).

A partir do DGGE realizado com primers para as BRS, de amostra da lagoa anaeróbia coletada às 02:00 h (T3), foi elaborado o dendrograma da Figura 5.24. Corte arbitrário de $67 \%$ de similaridade foi realizado, sendo possível observar três agrupamentos principais. No primeiro agrupamento, foram similares em $67 \%$, as distribuições dos microrganismos na sub-superfície e na camada intermediária, no verão. No segundo agrupamento, as distribuições dos microrganismos foram semelhantes na sub-superfície e 
na camada intermediária, no inverno ( $100 \%$ de similaridade), a qual por sua vez, foi similar à distribuição das BRS na interface água-sedimento, no outono ( $73 \%$ de similaridade). No terceiro agrupamento, apresentaram coeficiente de similaridade de $75 \%$, as distribuições dos microrganismos na interface água-sedimento, no verão, e na sub-superfície, no outono.

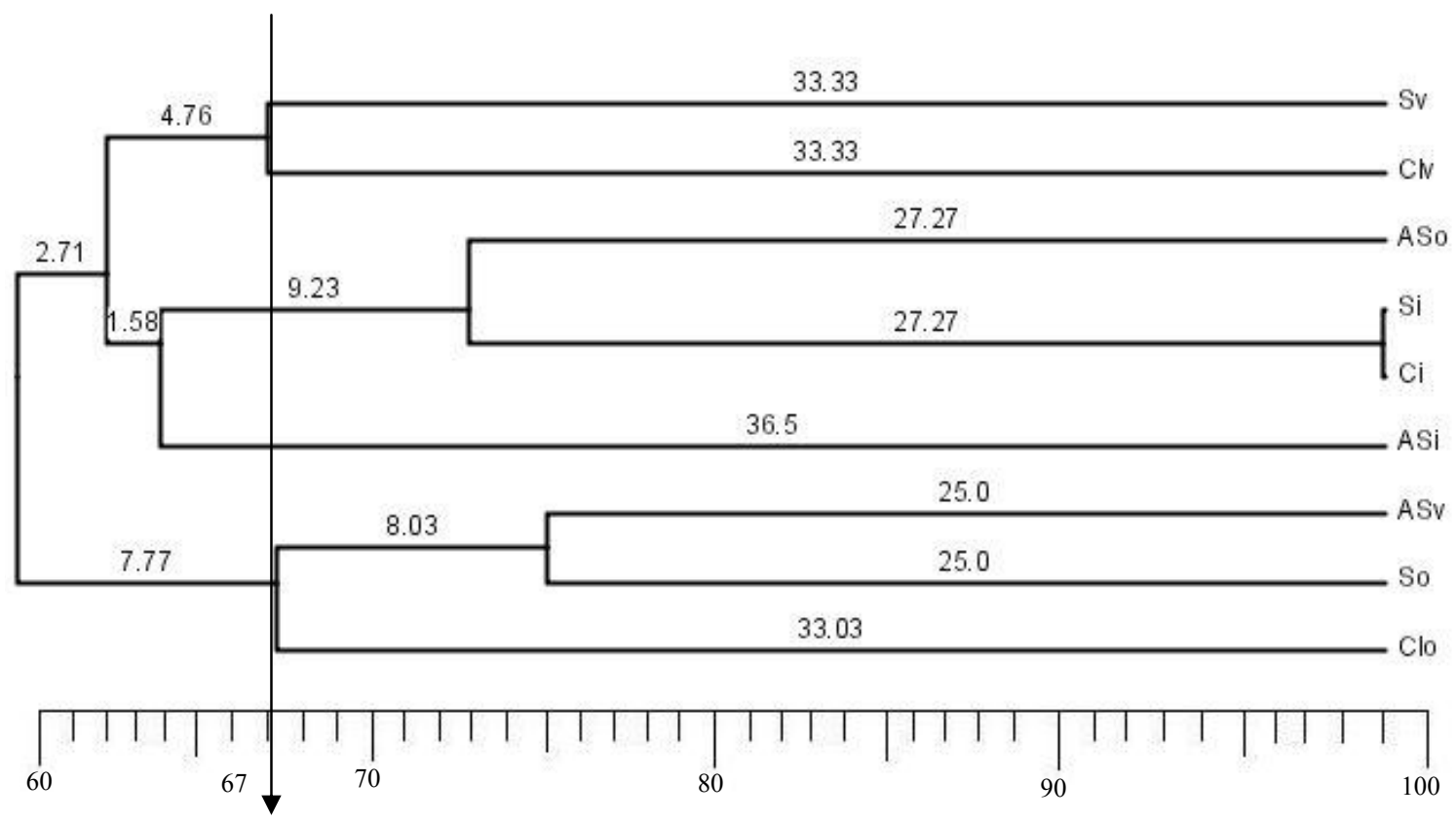

Figura 5.24: Dendrograma das variações sazonais na lagoa anaeróbia com primers para as BRS referente ao horário $\mathrm{T} 3(02: 00 \mathrm{~h})$.

$\mathrm{S}=$ sub-superfície, $\mathrm{CI}=$ camada intermediária, $\mathrm{AS}=$ interface água-sedimento. A régua indica porcentagens do coeficiente de similaridade

Os valores de $\mathrm{pH}$, temperatura e oxigênio dissolvido na sub-superfície, no verão, foram de 9,$6 ; 28,3^{\circ} \mathrm{C}$ e $4,0 \mathrm{mg} / \mathrm{L}$, respectivamente. Na camada intermediária, os valores foram de 9,$1 ; 25,4^{\circ} \mathrm{C}$ e $0,1 \mathrm{mg} / \mathrm{L}$, respectivamente. Com esses valores apresentados, ambas as profundidades apresentaram $67 \%$ de similaridade, com presença de 2 e 4 bandas, respectivamente.

Os valores de $\mathrm{pH}$, temperatura e oxigênio dissolvido na sub-superfície, no inverno, foram de 8,$5 ; 20,4^{\circ} \mathrm{C}$ e $6,3 \mathrm{mg} / \mathrm{L}$, respectivamente. Na camada intermediária, os valores foram de 8,$3 ; 19,6^{\circ} \mathrm{C}$ e $0,3 \mathrm{mg} / \mathrm{L}$, respectivamente. Com $\mathrm{pH}$ alcalino e temperatura 
psicrofílica, desenvolveram-se populações similares de microrganismos em ambas as profundidades. Foram observadas, no perfil de bandas padrões do DGGE 6 bandas similares, em ambas as profundidades (100\% de similaridade).

Os valores de $\mathrm{pH}$, temperatura e oxigênio dissolvido na interface água-sedimento, no verão, foram de 9,$0 ; 25,2^{\circ} \mathrm{C}$ e $0,08 \mathrm{mg} / \mathrm{L}$, respectivamente. $\mathrm{Na}$ sub-superfície, no outono, os valores foram de 7,$8 ; 30,5^{\circ} \mathrm{C}$ e $0,14 \mathrm{mg} / \mathrm{L}$, respectivamente. Possivelmente, devido ao menor $\mathrm{pH}$ e maior temperatura, verificados no outono, as duas profundidades tenham apresentado $75 \%$ de similaridade.

$\mathrm{Na}$ coleta realizada no outono, às 14:00 $\mathrm{h}$, foi maior a diversidade de BRS na subsuperfície, camada intermediária e na interface água-sedimento com 8,10 e 11 bandas, respectivamente; e no verão, 7, 4 e 2 bandas, respectivamente. No outono e verão, quando foi observada maior diversidade das BRS, foram verificadas as maiores porcentagens de remoção de sulfato, com $100 \%$ e $79,6 \%$, respectivamente, possivelmente realizada por esse grupo específico de microrganismos ou por outras bactérias, pelo metabolismo assimilativo.

No horário de coleta das 02:00 h, no outono, foram verificadas 3, 5 e 7 bandas na sub-superfície, camada intermediária e interface água sedimento, respectivamente. Nesse mesmo horário, porém no verão, foram verificadas 6,6 e 3 bandas, respectivamente. As porcentagens de remoção de sulfato foram de $97 \%$ no outono, e $50 \%$ no verão. 


\subsubsection{Análise Geral dos Parâmetros Físico-químicos}

A concentração da matéria orgânica afluente esteve abaixo dos valores recomendados para esgoto forte. Segundo Metcalf (2001), o esgoto doméstico é considerado como forte quando apresenta DQO de $1.000 \mathrm{mg} / \mathrm{L}$. Na presente pesquisa, a DQO afluente variou de $50 \mathrm{mg} / \mathrm{L}$ na primavera, a $290 \mathrm{mg} / \mathrm{L}$ no verão. O fósforo total variou de $0,64 \mathrm{mg} / \mathrm{L}$ no verão a 7,0 mg/L na primavera; o nitrogênio total Kjeldahl variou de 13,1 $\mathrm{mg} / \mathrm{L}$ na primavera, a 39,9 mg/L no outono; o nitrogênio amoniacal variou de $1,8 \mathrm{mg} / \mathrm{L}$ no verão, a 36,8 mg/L na primavera. Todos esses valores apresentaram-se abaixo dos valores considerados como forte, para esgoto sanitário, e iguais a $15,0 \mathrm{mg} / \mathrm{L} ; 85,0 \mathrm{mg} / \mathrm{L}$ e 50,0 $\mathrm{mg} / \mathrm{L}$, respectivamente. $\mathrm{O}$ nitrato permaneceu acima do recomendado $(0,0 \mathrm{mg} / \mathrm{L})$, pois os valores variaram de $1,3 \mathrm{mg} / \mathrm{L}$ na primavera a $3,7 \mathrm{mg} / \mathrm{L}$ no verão.

Foi realizada análise de variância (ANOVA, da versão 7 do EXCEL) para verificar a remoção de nitrogênio amoniacal, nitrito e nitrato na lagoa anaeróbia, nos horários T1 e T3, para os diferentes pontos de coleta e épocas do ano. Não foram verificadas diferenças significativas entre os dois horários, pontos de coleta e épocas do ano $(\mathrm{p}=0,615)$ (Tabelas Anexo C1 e Anexo C2). A análise de variância indicou que não foram verificadas diferenças significativas na remoção de nitrogênio amoniacal, nitrito e nitrato na primavera e no inverno (período de seca), e nem no outono e verão (período de chuva), sendo o valor de $\mathrm{p}=0,543$ (Tabelas Anexo C6 e Anexo C7). O mesmo foi observado para os diferentes pontos de coleta $(\mathrm{p}=0,764)$ (Tabelas Anexo C7 e Anexo C8).

Segundo Von Sperling et al. (2003), faixas ótimas de eficiência de remoção podem servir de referência para a maioria das regiões brasileiras, desde que a temperatura média da água residuária esteja entre $20^{\circ} \mathrm{C}$ a $25^{\circ} \mathrm{C}$, no mês mais frio do ano. No presente trabalho, a temperatura da água variou de $19,4^{\circ} \mathrm{C}$ a $26,9^{\circ} \mathrm{C}$ em julho, mês mais frio do período de coleta.

As Tabelas 5.2 e 5.3 mostram os valores dos parâmetros físico-químicos verificados no afluente e efluente da lagoa anaeróbia. A Tabela 5.4 apresenta as porcentagens de remoção na lagoa anaeróbia. No outono foi verificada a maior remoção de sulfato (100\%), no horário das $14: 00 \mathrm{~h}$ (temperatura de $27,8^{\circ} \mathrm{C}$ e $27,23^{\circ} \mathrm{C}$ afluente e efluente, respectivamente). $\mathrm{Na}$ primavera foi verificada a maior remoção de matéria orgânica 
$\left(\mathrm{DQO}_{\mathrm{b}}\right.$ ), no horário das 02:00 h, com $65,9 \%$ (temperatura de $23,5^{\circ} \mathrm{C}$ e $24,0^{\circ} \mathrm{C}$ afluente e efluente, respectivamente). A remoção de $100 \%$ de sólidos suspensos voláteis foi verificada no outono, no horário das 14:00 h. A remoção de 51,8\% de NTK foi observada no outono, (temperatura de $27,9^{\circ} \mathrm{C}$ e $27,8^{\circ} \mathrm{C}$ afluente e efluente, respectivamente), no horário $\mathrm{T} 3$ (02:00h) e a remoção de $78,7 \%$ de fósforo total foi verificada na primavera (temperatura de $23,5^{\circ} \mathrm{C}$ e $24,0^{\circ} \mathrm{C}$ afluente e efluente, respectivamente), no horário das 02:00 h. As menores porcentagens de redução de NTK e PT foram observadas no verão, quando a temperatura variou de $26,2^{\circ} \mathrm{C}$ a $27,0^{\circ} \mathrm{C}$, respectivamente. Maior remoção de nitrato foi observada no verão, com $67,2 \%$, no horário das $02: 00 \mathrm{~h}$, assim como a de nitrito $(91,9 \%)$. A remoção de $48,3 \%$ de nitrogênio amoniacal foi verificada no outono, às 14:00 h e a maior remoção de fósforo total dissolvido, de $62,4 \%$, foi verificada no verão, no horário das 14:00 h, assim como a de ortofosfato $(51,2 \%)$.

Tabela 5.2: Valores dos parâmetros físico-químicos verificados no afluente e efluente da lagoa anaeróbia no horário T1 $(14: 00 \mathrm{~h})$

\begin{tabular}{l|cccccc}
\hline \multicolumn{1}{c|}{ Parâmetros } & \multicolumn{3}{|c}{ AFLUENTE } & \multicolumn{3}{c}{ EFLUENTE } \\
& Primavera & Verão & Outono & Primavera & Verão & Outono \\
& & & & & & \\
Sulfato $(\mathrm{mg} / \mathrm{L})$ & 48 & 54 & 57 & 20 & 11 & 0,0 \\
$\mathrm{DQO}(\mathrm{mg} / \mathrm{L})$ & 50 & 290 & 259,2 & 122 & 148 & 174,3 \\
$\mathrm{SSV}(\mathrm{mg} / \mathrm{L})$ & 120 & 60 & 97 & 213 & 93 & 0,0 \\
$\mathrm{NTK}(\mathrm{mg} / \mathrm{L})$ & 13,07 & 30,24 & 39,85 & 28,75 & 26,23 & 19,69 \\
$\mathrm{PT}(\mathrm{mg} / \mathrm{L})$ & 6,78 & 1,14 & 4,54 & 3,84 & 0,86 & 3,36 \\
Nitrato $(\mathrm{mg} / \mathrm{L})$ & 2,09 & 3,67 & 2,54 & 1,85 & 1,66 & 2,59 \\
Nitrito $(\mu \mathrm{g} / \mathrm{L})$ & 8,91 & 13,93 & 15,52 & 3,66 & 6,0 & 4,48 \\
Nitrogênio & 7,92 & 14,45 & 29,79 & 18,96 & 11,59 & 15,4 \\
amoniacal $(\mathrm{mg} / \mathrm{L})$ & & & & & & \\
PTD $(\mu \mathrm{g} / \mathrm{L})$ & 733,75 & 2635,65 & 3,51 & 2913,1 & 992,15 & 2,32 \\
Ortofosfato $(\mu \mathrm{g} / \mathrm{L})$ & 178,15 & 2017,05 & 3,56 & 1009,5 & 984,25 & 2,12 \\
\hline
\end{tabular}

PT: fósforo total; PTD: fósforo total dissolvido 
Tabela 5.3: Valores dos parâmetros físico-químicos verificados no afluente e efluente da lagoa anaeróbia no horário T3 $(02: 00 \mathrm{~h})$

\begin{tabular}{|c|c|c|c|c|c|c|}
\hline \multirow{2}{*}{ Parâmetros } & \multicolumn{3}{|c|}{ AFLUENTE } & \multicolumn{3}{|c|}{ EFLUENTE } \\
\hline & Primavera & Verão & Outono & Primavera & Verão & Outono \\
\hline Sulfato $(\mathrm{mg} / \mathrm{L})$ & 63 & 32 & 34 & 11 & 16 & 1,0 \\
\hline $\mathrm{DQO}_{\mathrm{b}}(\mathrm{mg} / \mathrm{L})$ & 255 & 88 & 268,6 & 87 & 106 & 134,7 \\
\hline $\operatorname{SSV}(\mathrm{mg} / \mathrm{L})$ & 93 & 37 & 0,0 & 6 & 70 & 90 \\
\hline NTK (mg/L) & 25,95 & 17,17 & 33,51 & 28 & 10,73 & 16,15 \\
\hline $\mathrm{PT}(\mathrm{mg} / \mathrm{L})$ & 7,01 & 0,64 & 3,62 & 1,49 & 1,64 & 4,15 \\
\hline Nitrato $(\mathrm{mg} / \mathrm{L})$ & 1,35 & 1,83 & 3,37 & 1,46 & 0,6 & 2,48 \\
\hline Nitrito $(\mu \mathrm{g} / \mathrm{L})$ & 0,16 & 58,97 & 7,16 & 4,68 & 4,78 & 3,31 \\
\hline $\begin{array}{l}\text { Nitrogênio } \\
\text { amoniacal (mg/L) }\end{array}$ & 15,62 & 2,97 & 21,98 & 48,58 & 8,96 & 14,11 \\
\hline PTD $(\mu \mathrm{g} / \mathrm{L})$ & 1561,15 & 105,16 & 2,86 & 3835 & 882,1 & 2,2 \\
\hline Ortofosfato $(\mu \mathrm{g} / \mathrm{L})$ & 1267,9 & 1299,2 & 2,68 & 2111,5 & 766,5 & 1,74 \\
\hline
\end{tabular}

Tabela 5.4: Eficiências de redução dos parâmetros físico-químicos verificados na lagoa anaeróbia

\begin{tabular}{l|cccccc}
\hline \multicolumn{1}{c|}{ Parâmetros } & \multicolumn{3}{c}{ \% Remoção (T1) } & \multicolumn{3}{c}{ \% Remoção (T3) } \\
& Primavera & Verão & Outono & Primavera & Verão & Outono \\
& & & & & & \\
& 58,3 & 79,6 & 100 & 82,5 & 50,0 & 97,0 \\
Sulfato $(\mathrm{mg} / \mathrm{L})$ & $*$ & 49 & 32,8 & 65,9 & $*$ & 49,9 \\
DQO $(\mathrm{mg} / \mathrm{L})$ & $*$ & $*$ & 100 & 93,5 & $*$ & $*$ \\
$\mathrm{SSV}(\mathrm{mg} / \mathrm{L})$ & $*$ & 13,3 & 50,6 & $*$ & 37,5 & 51,8 \\
NTK $(\mathrm{mg} / \mathrm{L})$ & 43,4 & 24,6 & 26 & 78,7 & $*$ & $*$ \\
PT $(\mathrm{mg} / \mathrm{L})$ & 11,5 & 54,8 & $*$ & 45,5 & 67,2 & 26,4 \\
Nitrato $(\mathrm{mg} / \mathrm{L})$ & 58,9 & 56,9 & 71,1 & $*$ & 91,9 & 53,8 \\
Nitrito $(\mu \mathrm{gg} / \mathrm{L})$ & $*$ & 19,8 & 48,3 & 35,7 & $*$ & 35,8 \\
Nitrogênio & & & & & & \\
amoniacal $(\mathrm{mg} / \mathrm{L})$ & $*$ & 62,4 & 33,9 & 59,4 & $*$ & 23,1 \\
PTD $(\mathrm{mg} / \mathrm{L})$ & $*$ & 51,2 & 40,4 & 27,8 & 41,0 & 35,1 \\
\hline Ortofosfato $(\mathrm{mg} / \mathrm{L})$ & &
\end{tabular}

*houve aumento dessa variável no efluente final PT: fósforo total; PTD: fósforo total dissolvido 


\subsection{Lagoa facultativa}

\subsubsection{Diversidade do Domínio Bacteria}

\subsubsection{Amostragem Diurna}

A partir do DGGE realizado com primers para o Domínio Bacteria, de amostra da lagoa facultativa coletada às 14:00 h (T1), foi elaborado o dendrograma da Figura 5.25. Corte arbitrário de $75 \%$ de similaridade foi realizado, sendo possível observar quatro agrupamentos principais. O primeiro e segundo agrupamentos relacionaram as distribuições dos microrganismos encontrados na primavera e verão. Na primavera, foi observado $100 \%$ de similaridade na camada intermediária e na interface água-sedimento, que por sua vez relacionaram-se com 90\% de similaridade, com a sub-superfície, na mesma época do ano. As distribuições dos microrganismos na sub-superfície e camada intermediária, no verão, apresentaram $89 \%$ de similaridade. O terceiro agrupamento relacionou a sub-superfície e a camada intermediária, no outono, com $90 \%$ de similaridade. O quarto agrupamento mostrou $100 \%$ de similaridade, entre a camada intermediária e a interface água-sedimento, no inverno.

A radiação solar fotossinteticamente ativa incidente no horário de coleta das 14:00 $\mathrm{h}$, na superfície da lagoa, na primavera, foi de $221,3 \mu \mathrm{Em}^{-2} \mathrm{~s}^{-1}$. Os valores de $\mathrm{pH}$, temperatura e oxigênio dissolvido, na sub-superfície, foram de 8,$8 ; 23,5^{\circ} \mathrm{C}$ e $0,3 \mathrm{mg} / \mathrm{L}$, respectivamente. $\mathrm{Na}$ camada intermediária, os valores foram de 9,$0 ; 23,4^{\circ} \mathrm{C}$ e $0,3 \mathrm{mg} / \mathrm{L}$, respectivamente. $\mathrm{Na}$ interface água-sedimento, os valores foram de 9,$1 ; 23,3^{\circ} \mathrm{C}$ e 0,05 $\mathrm{mg} / \mathrm{L}$, respectivamente. Menor número de bandas foi observado na sub-superfície, quando comparado com a camada intermediária e a interface água-sedimento. Nesses últimos pontos de amostragem a similaridade foi de $100 \%$; ou seja, foram observadas populações semelhantes de bactérias. Nessa época do ano foi observada maior diversidade de bactérias na sub-superfície, camada intermediária e interface água-sedimento (8, 9 e 9 bandas, respectivamente) quando comparado com os resultados obtidos no mesmo horário, na lagoa anaeróbia (5, 6 e 5 bandas respectivamente). 


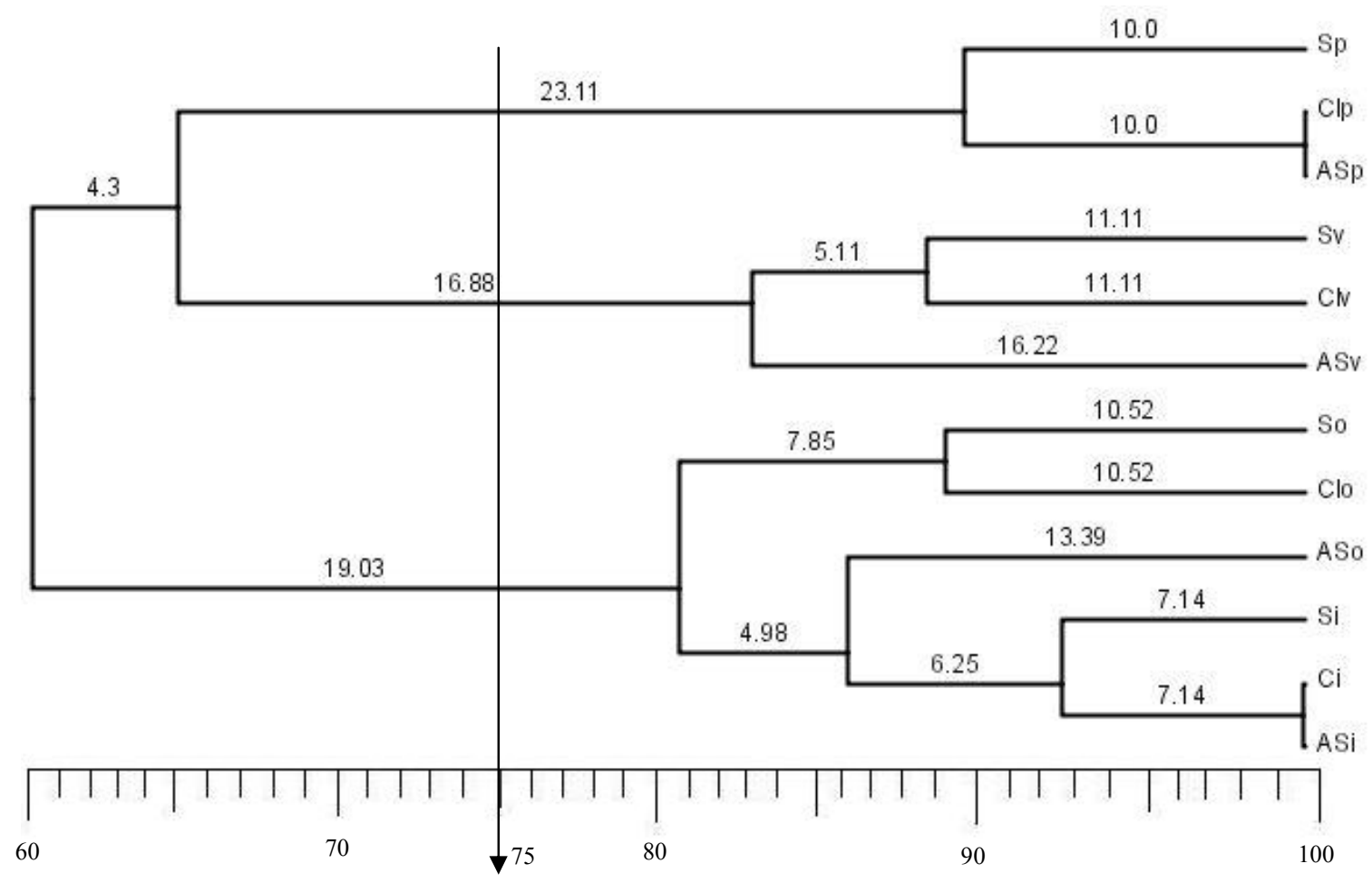

Figura 5.25: Dendrograma das variações sazonais na lagoa facultativa com primers para o Domínio Bacteria refente ao horário $\mathrm{T} 1(14: 00 \mathrm{~h})$.

$\mathrm{S}=$ sub-superfície, $\mathrm{CI}=$ camada intermediária, $\mathrm{AS}=$ interface água-sedimento. A régua indica porcentagens do coeficiente de similaridade

A radiação solar fotossinteticamente ativa incidente na superfície da lagoa, no verão, foi de $1.344 \mu \mathrm{Em}^{-2} \mathrm{~s}^{-1}$. Os valores de $\mathrm{pH}$, temperatura e oxigênio dissolvido na subsuperfície, foram de 12,$0 ; 32,1^{\circ} \mathrm{C}$ e $9,5 \mathrm{mg} / \mathrm{L}$, respectivamente. Na camada intermediária, os valores foram de 9,$5 ; 26,1^{\circ} \mathrm{C}$ e $0,02 \mathrm{mg} / \mathrm{L}$, respectivamente. $\mathrm{Na}$ interface águasedimento, os valores foram de 10,$0 ; 25,4^{\circ} \mathrm{C}$ e $0,10 \mathrm{mg} / \mathrm{L}$, respectivamente. Essas faixas de valores observadas no verão, e similaridade de $89 \%$ entre a interface água-sedimento com a sub-superfície e a camada intermediária, foram verificadas populações semelhantes de bactérias nas diferentes profundidades. Esses valores foram superiores aos verificados para a lagoa anaeróbia (9, 8 e 9 bandas, respectivamente), na mesma época; ou seja, com 14, 16 e 13 bandas observadas na lagoa facultativa.

A radiação solar fotossinteticamente ativa incidente na superfície da lagoa, no outono, foi de $409,9 \mu \mathrm{Em}^{-2} \mathrm{~s}^{-1}$. Os valores de $\mathrm{pH}$, temperatura e oxigênio dissolvido na subsuperfície, foram de 10,$0 ; 34,3^{\circ} \mathrm{C}$ e $7,2 \mathrm{mg} / \mathrm{L}$. Na camada intermediária, os valores foram 
de 9,$3 ; 27,5^{\circ} \mathrm{C}$ e $1,1 \mathrm{mg} / \mathrm{L}$, respectivamente. $\mathrm{O} \mathrm{pH}$ alcalino e a temperatura mesofílica favoreceram, nessa época do ano, maior diversidade do Domínio Bacteria, com 15 e 17 bandas, respectivamente. Tais valores foram superiores ao verificado para a lagoa anaeróbia na mesma época ( 9 e 8 bandas, respectivamente), com similaridade de $90 \%$.

A radiação solar fotossinteticamente ativa incidente na superfície da lagoa, no inverno, foi de $519,8 \mu \mathrm{Em}^{-2} \mathrm{~s}^{-1}$. Os valores de $\mathrm{pH}$, temperatura e oxigênio dissolvido, na sub-superfície, foram de 10,$3 ; 20,1^{\circ} \mathrm{C}$ e $5,6 \mathrm{mg} / \mathrm{L}$. Na camada intermediária, os valores foram de 10,$1 ; 19,8^{\circ} \mathrm{C}$ e $4,4 \mathrm{mg} / \mathrm{L}$, respectivamente. Na interface água-sedimento, os valores foram de 10,$0 ; 19,6^{\circ} \mathrm{C}$ e $2,9 \mathrm{mg} / \mathrm{L}$, respectivamente. Na interface água-sedimento, no outono, os valores foram de 8,$2 ; 26,5^{\circ} \mathrm{C}$ e $0,10 \mathrm{mg} / \mathrm{L}$, respectivamente. Sob essas condições físico-químicas, e com similaridades variando de $87 \%$ a $100 \%$, desenvolveramse populações de bactérias no inverno, semelhantes às da interface água-sedimento, no outono.

Avaliando o perfil de bandas padrões do DGGE realizado com primers para o Domínio Bacteria, observou-se menor e maior diversidade de bactérias, na sub-superfície, na primavera ( 8 bandas) e no outono (15 bandas), respectivamente. Na primavera, foi verificada menor intensidade luminosa $\left(221,3 \mu \mathrm{Em}^{-2} \mathrm{~s}^{-1}\right)$ que a registrada no outono $(409,9$ $\left.\mu \mathrm{Em}^{-2} \mathrm{~s}^{-1}\right)$. Também, na primavera, o valor de $\mathrm{pH}$ na sub-superfície $(8,8)$ foi inferior ao verificado na sub-superfície, no outono $(10,0)$, fato que também pode ter influenciado na menor diversidade observada naquela época (Figura 5.26).

Os valores mínimo e máximo de $\mathrm{pH}$ foram de 8,2 no outono, e 12,0 no verão, respectivamente. No outono, os valores de $\mathrm{pH}$ foram menores aos das outras épocas do ano, e iguais a 8,2 na interface água-sedimento, e 10,0 na sub-superfície. Possivelmente, sob essas condições de $\mathrm{pH}$, ocorreu favorecimento de maior diversidade do Domínio Bacteria verificado na lagoa (Anexos B4, B10, B16 e B22). Granado (2004) também encontrou valores de $\mathrm{pH}$ superiores na superfície, no outono, no horário das 15:00 h, para as lagoas facultativa 1 e 2 . Na lagoa facultativa 1 foi de 7,6; e na lagoa facultativa 2, de 9,9.

O pH afluente variou de 9,1 na primavera, a 10,1 no verão, valores superiores ao recomendado por von Sperling (1996), que devem estar entre 6,7 a 7,5. Todavia, no outono o valor foi de 7,0. O pH efluente variou de 8,6 no verão e outono, a 9,9 no inverno. Gomes (2002) verificou valores menores no efluente final da lagoa de estabilização de Coroados, 
variando de 7,1 no inverno, a 7,6 no outono; e na lagoa de estabilização de Lourdes, de 7,1 no outono, a 7,7 no inverno. Fiorini (2004) observou, no efluente da lagoa facultativa de Cajati, menor pH em março, com média de 8,2. Nos meses de junho, julho e setembro a média foi de 7,5. Em novembro, a média foi de 7,8. Falco (2005) verificou valores menores no efluente final, variando de 7,1 no outono, a 7,7 na primavera e verão.

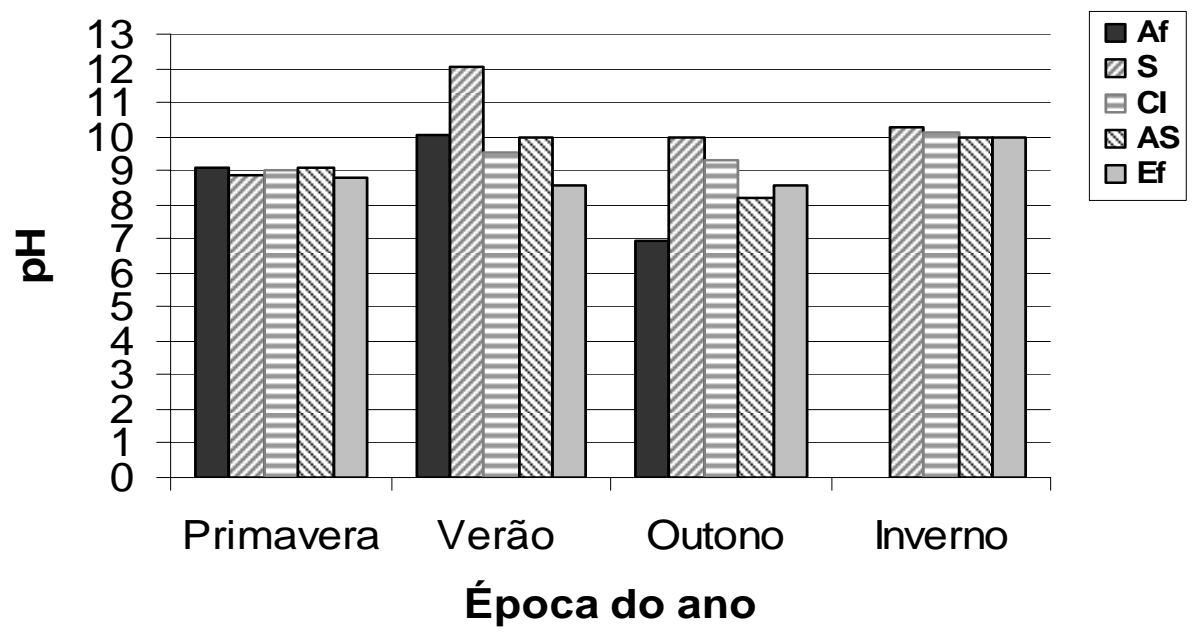

Figura 5.26: Variações sazonais de $\mathrm{pH}$ na lagoa facultativa referente ao horário T1 (14:00 h) $\mathrm{Af}=$ afluente, $\mathrm{S}=$ sub-superfície, $\mathrm{CI}=$ camada intermediária, $\mathrm{AS}=$ interface água-sedimento, $\mathrm{Ef}=$ efluente

A temperatura na sub-superfície, na primavera, foi de $23,5^{\circ} \mathrm{C}$, e no outono foi de $34,3^{\circ} \mathrm{C}$ (Figura 5.27). Possivelmente, essa temperatura superior no outono, assim como foi verificado na lagoa anaeróbia, foi favorável para o desenvolvimento dos microrganismos nessa época do ano. Os valores de temperatura oscilaram na faixa de $19,6^{\circ} \mathrm{C}$ no inverno, a $34,3^{\circ} \mathrm{C}$ no outono. A temperatura afluente variou de $22,9^{\circ} \mathrm{C}$ na primavera, a $27,2^{\circ} \mathrm{C}$ no outono (Anexos B4, B10, B16 e B22). A temperatura efluente variou de $22,3^{\circ} \mathrm{C}$ no inverno, a $32,3{ }^{\circ} \mathrm{C}$ no outono. Gomes (2002) verificou temperaturas menores no efluente final da lagoa de estabilização de Coroados, variando de $19,0^{\circ} \mathrm{C}$ no inverno, a $26,0^{\circ} \mathrm{C}$ no outono; e na lagoa de estabilização de Lourdes, de $21,0^{\circ} \mathrm{C}$ no inverno, a $26,0^{\circ} \mathrm{C}$ no outono. Fiorini (2004) verificou, na lagoa facultativa de Cajati, temperatura média da água em junho, julho e setembro, de $22^{\circ} \mathrm{C}$. Em novembro e março, esta foi de $27^{\circ} \mathrm{C}$. Falco (2005) obteve faixas similares no efluente final, de $23,0^{\circ} \mathrm{C}$ no inverno, a $30,0^{\circ} \mathrm{C}$ no verão. 


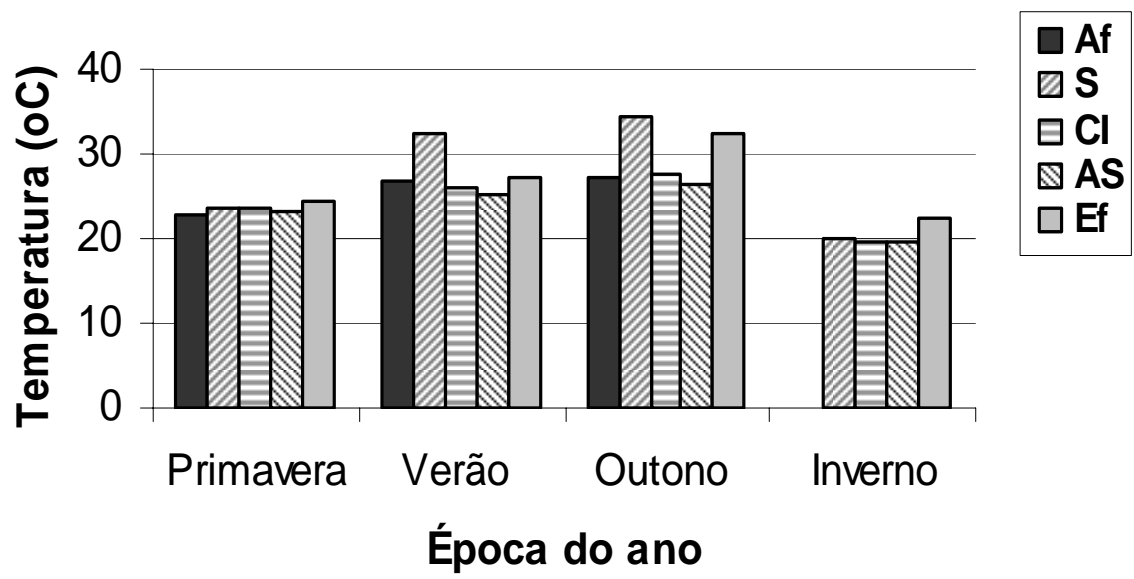

Figura 5.27: Variações sazonais de temperatura na lagoa facultativa referente ao horário T1 (14:00 h) Af $=$ afluente, $\mathrm{S}=$ sub-superfície, $\mathrm{CI}=$ camada intermediária, $\mathrm{AS}=$ interface água-sedimento, $\mathrm{Ef}=$ efluente

A concentração de oxigênio dissolvido na sub-superfície, na primavera, foi de 0,3 $\mathrm{mg} / \mathrm{L}$, e no outono, de 7,2 mg/L. Essa concentração de oxigênio dissolvido verificada na sub-superfície, no outono, possivelmente também permitiu o maior desenvolvimento de bactérias nessa época, favorecendo o crescimento de bactérias facultativas e aeróbias. As concentrações mínima e máxima de oxigênio dissolvido foram de $0,02 \mathrm{mg} / \mathrm{L}$ e 9,5 mg/L, ambas no verão, respectivamente (Figura 5.28). As concentrações de oxigênio dissolvido afluente oscilaram de $0,34 \mathrm{mg} / \mathrm{L}$ na primavera, a $1,3 \mathrm{mg} / \mathrm{L}$ no verão. As concentrações foram variáveis nas quatro coletas realizadas, assim como nos diferentes pontos de amostragem (Anexos B4, B10, B16 e B22). Granado (2004) verificou maiores concentrações de oxigênio dissolvido na superfície, no horário das 15:00 h, exceto na primavera. Na lagoa facultativa 1 , no outono, esta foi de $3,1 \mathrm{mg} / \mathrm{L}$; no inverno foi de 10,8 $\mathrm{mg} / \mathrm{L}$ e no verão, 9,0 mg/L. Na lagoa facultativa 2, no outono, foi de 19,2 mg/L; no inverno, $5,5 \mathrm{mg} / \mathrm{L}$ e no verão, $13,3 \mathrm{mg} / \mathrm{L}$.

As concentrações de oxigênio dissolvido no efluente variaram de $5,2 \mathrm{mg} / \mathrm{L}$ no inverno, a 2,8 mg/L no verão. Gomes (2002) verificou valores menores no efluente final da lagoa de estabilização de Coroados, variando de $0,8 \mathrm{mg} / \mathrm{L}$ no inverno, a $2,0 \mathrm{mg} / \mathrm{L}$ no outono; e na lagoa de estabilização de Lourdes, de $2,5 \mathrm{mg} / \mathrm{L}$ no inverno, a 3,0 mg/L no 
outono e inverno. Fiorini (2004) verificou no efluente da lagoa facultativa de Cajati, concentração média de oxigênio dissolvido, em junho e julho, de 9,2 mg/L. Em setembro, a concentração média foi de 5,6 mg/L. Em novembro e março, as médias foram de 5,1 mg/L e 4,4 mg/L, respectivamente. Falco (2005) obteve valores menores no efluente final, variando de $0,9 \mathrm{mg} / \mathrm{L}$ no verão, a 3,6 mg/L no outono.
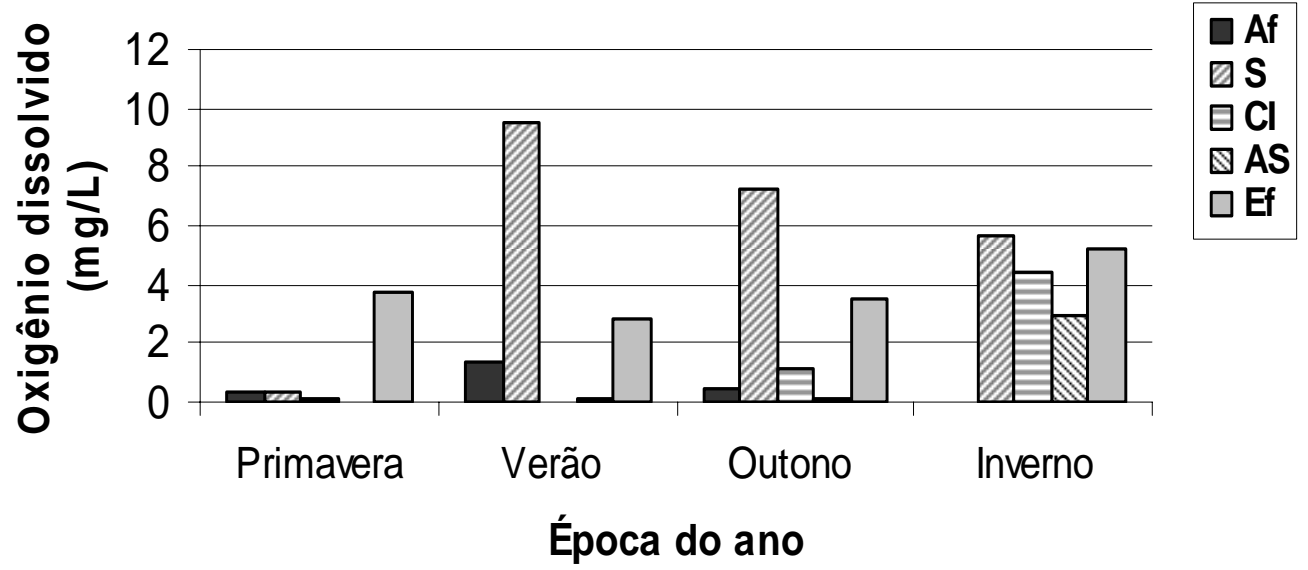

Figura 5.28: Variações sazonais de oxigênio dissolvido na lagoa facultativa referente ao horário T1 $(14: 00 \mathrm{~h})$

$\mathrm{Af}=$ afluente, $\mathrm{S}=$ sub-superfície, $\mathrm{CI}=$ camada intermediária, $\mathrm{AS}=$ interface água-sedimento, $\mathrm{Ef}=$ efluente

A concentração de sulfato na sub-superfície foi de $15,0 \mathrm{mg} / \mathrm{L}$ na primavera, e 1,0 $\mathrm{mg} / \mathrm{L}$ no outono (Figura 5.29). As concentrações de sulfato afluente variaram de $0,0 \mathrm{mg} / \mathrm{L}$ no outono, a 15,0 mg/L na primavera. Essas concentrações de sulfato foram menores em relação aos valores verificados na lagoa anaeróbia, no mesmo horário. Sob tais condições, foi verificada maior diversidade do Domínio Bacteria na lagoa facultativa (Anexos B4, B10, B16 e B22). No efluente, as concentrações de sulfato variaram de $0,0 \mathrm{mg} / \mathrm{L}$ no inverno, a $12,0 \mathrm{mg} / \mathrm{L}$ no verão. 


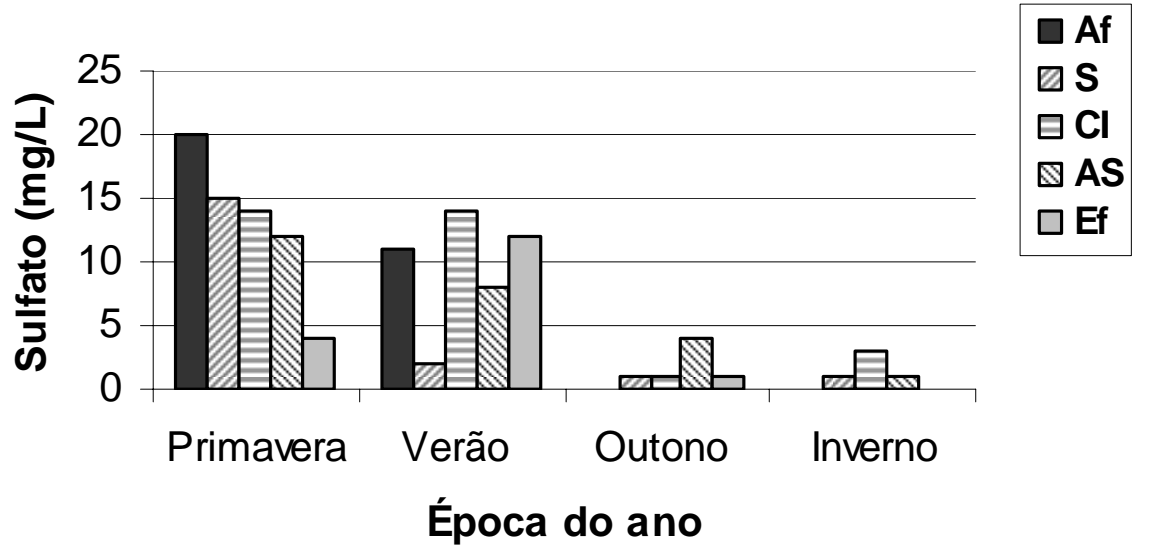

Figura 5.29: Variações sazonais de sulfato na lagoa facultativa referente ao horário T1 (14:00 h) $\mathrm{Af}=$ afluente, $\mathrm{S}=$ sub-superfície, $\mathrm{CI}=$ camada intermediária, $\mathrm{AS}=$ interface água-sedimento, $\mathrm{Ef}=$ efluente

A concentração da matéria orgânica bruta $\left(\mathrm{DQO}_{\mathrm{b}}\right)$ na sub-superfície, na primavera, foi de 106,0 mg/L e, no outono, de 108,2 mg/L (Figura 5.30). A DQO no inverno, a 169,0 mg/L no verão. No afluente, variou de $174,3 \mathrm{mg} / \mathrm{L}$ no outono, a 122,0 $\mathrm{mg} / \mathrm{L}$ na primavera (Anexos B4, B10, B16 e B22). No efluente final, a $\mathrm{DQO}_{\mathrm{b}}$ variou de $125,0 \mathrm{mg} / \mathrm{L}$ na primavera, a $173,7 \mathrm{mg} / \mathrm{L}$ no outono. Tais valores foram inferiores à faixa recomendada por Andrade Neto (1997), os quais devem compreender entre 200-300 mg/L para efluentes finais de lagoas de estabilização. Gomes (2002) verificou valores superiores no efluente final da lagoa de estabilização de Coroados, variando de 599,0 mg/L no inverno, a 717,0 mg/L no outono; e na lagoa de estabilização de Lourdes, de 503,0 mg/L no inverno, a 615,0 mg/L no outono. Falco (2005) obteve valores da matéria orgânica bruta no efluente final, variando de $151,0 \mathrm{mg} / \mathrm{L}$ no verão, a $330,0 \mathrm{mg} / \mathrm{L}$ no outono. 


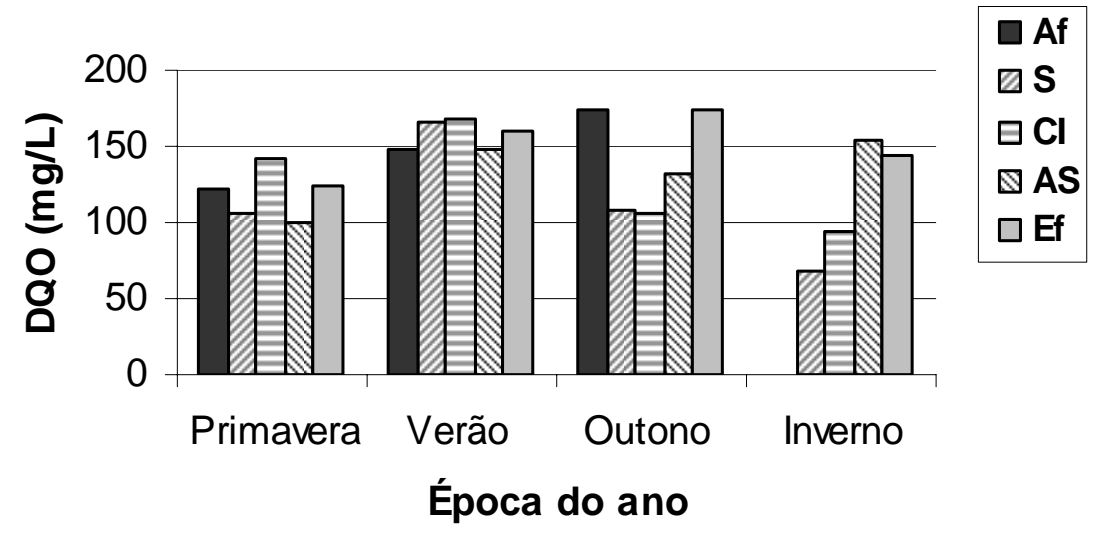

Figura 5.30: Variações sazonais de matéria orgânica na lagoa facultativa referente ao horário T1 $(14: 00 \mathrm{~h})$

$\mathrm{Af}=$ afluente, $\mathrm{S}=$ sub-superfície, $\mathrm{CI}=$ camada intermediária, $\mathrm{AS}=$ interface água-sedimento, $\mathrm{Ef}=$ efluente

A concentração de sólidos suspensos voláteis (SSV) na sub-superfície, na primavera $(180,0 \mathrm{mg} / \mathrm{L})$, foi superior ao verificado no outono $(0,0 \mathrm{mg} / \mathrm{L})$, assim como foi observado na lagoa anaeróbia; ou seja, maior concentração de SSV na primavera, possivelmente, em função da presença de outros organismos, tais como algas e protozoários. Este fato também foi verificado na camada intermediária e na interface água-sedimento, onde as concentrações de SSV, no outono, de 3,0 e 47,0 mg/L, respectivamente, foram menores do que as verificadas na primavera $(150,0$ e $73,0 \mathrm{mg} / \mathrm{L}$, respectivamente). As concentrações mínima e máxima foram de $0,0 \mathrm{mg} / \mathrm{L}$ no outono e inverno, e de $180,0 \mathrm{mg} / \mathrm{L}$ na primavera (Figura 5.31). No afluente, variou de $0,0 \mathrm{mg} / \mathrm{L}$ no outono, a $213,0 \mathrm{mg} / \mathrm{L}$ na primavera (Anexos B4, B10, B16 e B22). No efluente, variou de 47,0 mg/L no outono, a 117,0 mg/L no verão. Gomes (2002) obteve valores superiores de SSV efluente da lagoa de estabilização de Coroados, variando de $125,0 \mathrm{mg} / \mathrm{L}$ no inverno, a $185,0 \mathrm{mg} / \mathrm{L}$ no outono; e na lagoa de estabilização de Lourdes, de $65,0 \mathrm{mg} / \mathrm{L}$ no inverno, a $150,0 \mathrm{mg} / \mathrm{L}$ no outono. Valores diferentes no efluente final foram verificadas por Falco (2005), variando de 40,0 $\mathrm{mg} / \mathrm{L}$ no verão, a $178,0 \mathrm{mg} / \mathrm{L}$ no inverno. 


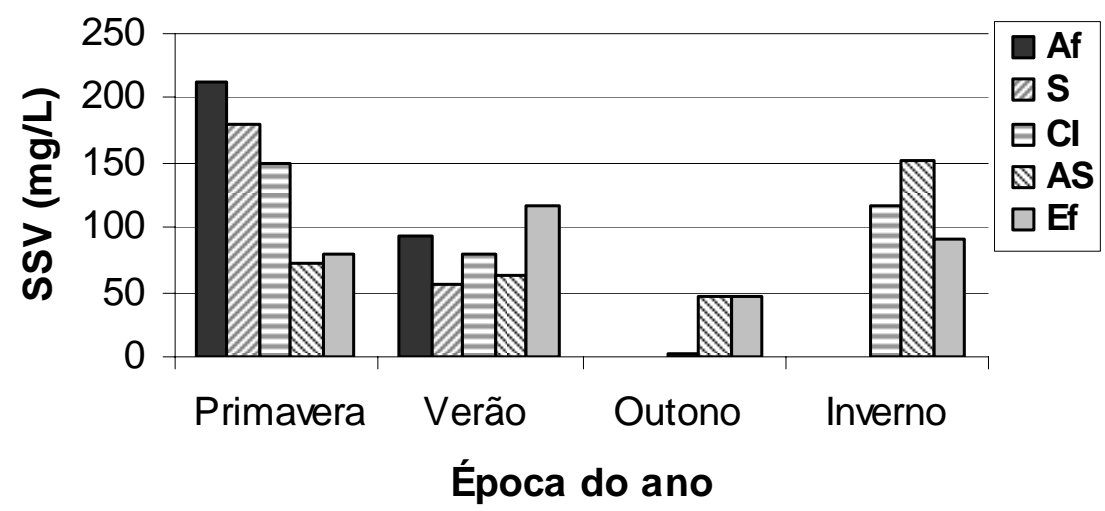

Figura 5.31: Variações sazonais de SSV na lagoa facultativa referente ao horário T1 (14:00 h) $\mathrm{Af}=$ afluente, $\mathrm{S}=$ sub-superfície, $\mathrm{CI}=$ camada intermediária, $\mathrm{AS}=$ interface água-sedimento, $\mathrm{Ef}=$ efluente

A concentração de NTK na sub-superfície, na primavera, foi de $29,5 \mathrm{mg} / \mathrm{L}$, e no outono foi de $8,1 \mathrm{mg} / \mathrm{L}$. Esse menor valor verificado no outono, pode significar, possivelmente, maior remoção de nitrogênio pelos microrganismos presentes na lagoa, que por sua vez, encontrou-se em maior diversidade nessa época do ano. Fato também verificado na lagoa anaeróbia. A concentração mínima de NTK foi de 6,5 mg/L no outono, e a máxima foi de $32,7 \mathrm{mg} / \mathrm{L}$, na primavera (Figura 5.32). Na primavera foi verificada maior concentração de NTK quando comparada com as de outras épocas do ano, assim como ao observado na lagoa anaeróbia (Anexos B5, B11, B17 e B23). No efluente, a concentração de NTK variou de 7,3 mg/L no inverno, a $30,4 \mathrm{mg} / \mathrm{L}$ na primavera. Valores superiores no efluente final foram verificados por Falco (2005), variando de 31,0 mg/L no verão, a $62,0 \mathrm{mg} / \mathrm{L}$ no inverno.

As concentrações de nitrato na sub-superfície, na primavera e inverno, foram de 1,4 $\mathrm{mg} / \mathrm{L} \mathrm{e} 1,5 \mathrm{mg} / \mathrm{L}$, respectivamente. No verão e outono, os valores foram iguais a $2,0 \mathrm{mg} / \mathrm{L} \mathrm{e}$ $2,4 \mathrm{mg} / \mathrm{L}$, respectivamente. As concentrações de nitrito na sub-superfície, na primavera e inverno, foram de 3,9 $\mu \mathrm{g} / \mathrm{L}$ e $1,5 \mu \mathrm{g} / \mathrm{L}$, respectivamente. No verão e outono, os valores foram iguais a 23,4 $\mu \mathrm{g} / \mathrm{L}$ e 7,4 $\mu \mathrm{g} / \mathrm{L}$, respectivamente. A variação da concentração de nitrito efluente foi de $1,1 \mu \mathrm{g} / \mathrm{L}$ no inverno, a $18,7 \mu \mathrm{g} / \mathrm{L}$ na primavera. A variação de nitrato foi de $1,3 \mathrm{mg} / \mathrm{L}$ no inverno, a $2,3 \mathrm{mg} / \mathrm{L}$ no outono. Gomes (2002) obteve valores similares de nitrato efluente da lagoa de estabilização de Coroados, variando de $0,99 \mathrm{mg} / \mathrm{L}$ a $3,8 \mathrm{mg} / \mathrm{L}$, ambos no inverno; e na lagoa de estabilização de Lourdes, de 0,09 mg/L no inverno, a 3,51 
$\mathrm{mg} / \mathrm{L}$ no outono. Em relação ao nitrito, o autor observou valores superiores no efluente da lagoa de estabilização de Coroados, variando de $0,18 \mathrm{mg} / \mathrm{L}$ no inverno, a $0,31 \mathrm{mg} / \mathrm{L}$ no outono; e na lagoa de estabilização de Lourdes, de $0,05 \mathrm{mg} / \mathrm{L}$ no inverno, a $0,13 \mathrm{mg} / \mathrm{L}$ no outono. Falco (2005) obteve valores similares de nitrato no efluente final, variando de 2,0 $\mathrm{mg} / \mathrm{L}$ no outono e primavera, a $4,0 \mathrm{mg} / \mathrm{L}$ no inverno, enquanto o nitrito variou de 0,008 $\mu \mathrm{g} / \mathrm{L}$ no outono, a $0,0282 \mu \mathrm{g} / \mathrm{L}$ no verão.

Neste estudo, o nitrogênio amoniacal efluente variou de $0,2 \mathrm{mg} / \mathrm{L}$ no inverno, a 9,2 $\mathrm{mg} / \mathrm{L}$ na primavera. Esse menor valor, verificado na primavera, pode ser devido ao $\mathrm{pH}$ alcalino verificado nessa época, que favoreceu a volatilização da amônia livre. Falco (2005) obteve valor de nitrogênio amoniacal no efluente final variando de $24,0 \mathrm{mg} / \mathrm{L}$ no verão, a $37,0 \mathrm{mg} / \mathrm{L}$ no inverno.

Fiorini (2004) verificou em setembro, no efluente da lagoa facultativa de Cajati, uma concentração média de nitrogênio total de $62,0 \mathrm{mg} / \mathrm{L}$. Em novembro, esta foi de 77,0 $\mathrm{mg} / \mathrm{L}$, em março de $25,0 \mathrm{mg} / \mathrm{L}$ e em julho, de $10,0 \mathrm{mg} / \mathrm{L}$.

Granado (2004) verificou na superfície da lagoa facultativa 1, no horário das 15:00 h, no outono, uma concentração de NTK de $52,1 \mathrm{mg} / \mathrm{L}$; nitrito de $0,006 \mathrm{mg} / \mathrm{L}$; nitrato de 2,5 $\mathrm{mg} / \mathrm{L}$ e nitrogênio amoniacal de $34,1 \mathrm{mg} / \mathrm{L}$. Na lagoa facultativa 2 , os valores foram de $51,1 \mathrm{mg} / \mathrm{L} ; 0,008 \mathrm{mg} / \mathrm{L} ; 2,3 \mathrm{mg} / \mathrm{L}$ e $33,1 \mathrm{mg} / \mathrm{L}$, respectivamente.

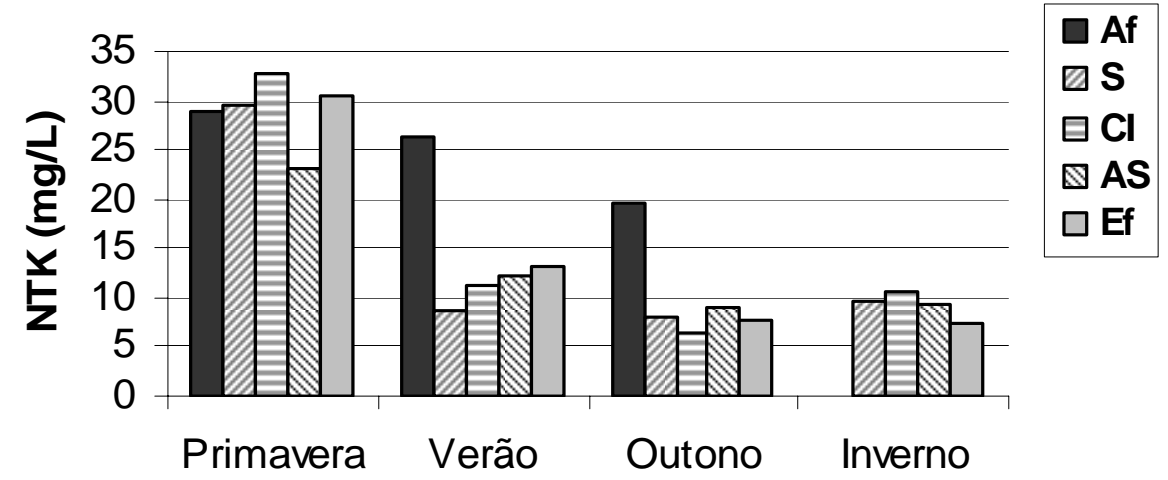

\section{Época do ano}

Figura 5.32: Variações sazonais de NTK na lagoa facultativa referente ao horário T1 (14:00 h) $\mathrm{Af}=$ afluente, $\mathrm{S}=$ sub-superfície, $\mathrm{CI}=$ camada intermediária, $\mathrm{AS}=$ interface água-sedimento, $\mathrm{Ef}=$ efluente 
A concentração de fósforo total na sub-superfície foi de $4,8 \mathrm{mg} / \mathrm{L}$ na primavera, e de $3,5 \mathrm{mg} / \mathrm{L}$ no outono (Figura 5.33). As concentrações de fósforo total dissolvido na subsuperfície, na primavera e outono, foram de $0,8 \mathrm{mg} / \mathrm{L}$ e $1,1 \mathrm{mg} / \mathrm{L}$, respectivamente. As concentrações de ortofosfato na sub-superfície, na primavera e outono, foram de $0,7 \mathrm{mg} / \mathrm{L}$ e $0,8 \mathrm{mg} / \mathrm{L}$, respectivamente.

A concentração mínima de fósforo total foi de $1,4 \mathrm{mg} / \mathrm{L}$ no verão, e máxima de 6,4 $\mathrm{mg} / \mathrm{L}$ no outono. A concentração afluente variou de $0,9 \mathrm{mg} / \mathrm{L}$ de fósforo, no verão, a 3,8 $\mathrm{mg} / \mathrm{L}$ na primavera. A concentração efluente variou de $1,6 \mathrm{mg} / \mathrm{L}$ no verão, a $12,3 \mathrm{mg} / \mathrm{L}$ na primavera. Também na primavera foram verificadas as maiores concentrações de fósforo total, assim como foi observado na lagoa anaeróbia, na mesma época do ano (Anexos B5, B11, B17 e B23). Gomes (2002) obteve valores superiores de fósforo total no efluente da lagoa de estabilização de Coroados, variando de $10,48 \mathrm{mg} / \mathrm{L}$ a $14,74 \mathrm{mg} / \mathrm{L}$, ambos no inverno; e na lagoa de estabilização de Lourdes, de 5,85 mg/L no outono, a 14,17 mg/L no inverno. Falco (2005) obteve, também, valores superiores de fósforo total no efluente, variando de $11,0 \mathrm{mg} / \mathrm{L}$ no verão, a $19,0 \mathrm{mg} / \mathrm{L}$ na primavera.

Granado (2004) verificou na superfície da lagoa facultativa 1, no horário das 15:00 h, no outono, concentração de ortofosfato de $0,08 \mathrm{mg} / \mathrm{L}$; e de fósforo total de $17,1 \mathrm{mg} / \mathrm{L}$. Na lagoa facultativa 2, os valores foram de $0,03 \mathrm{mg} / \mathrm{L}$, e de $17,1 \mathrm{mg} / \mathrm{L}$, respectivamente.

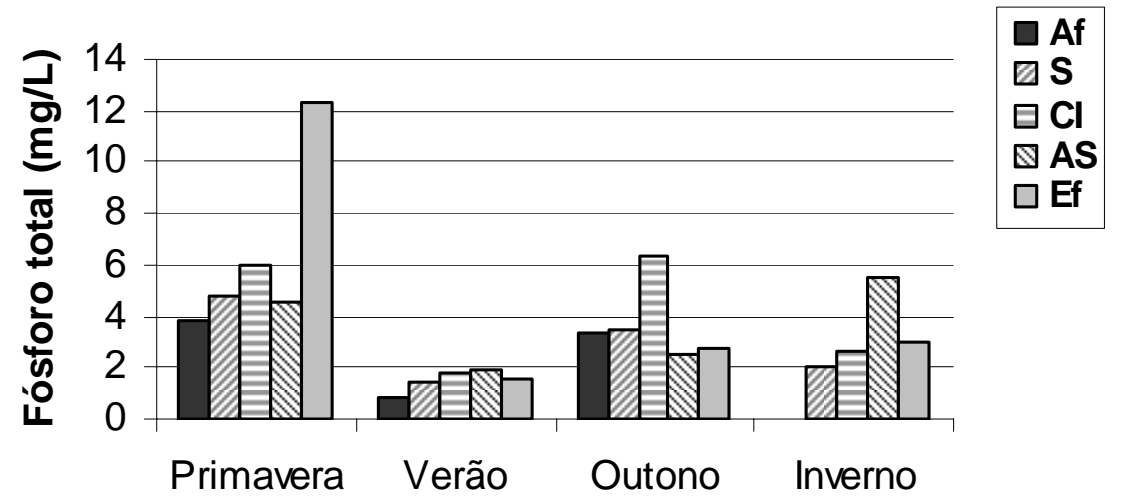

Época do ano

Figura 5.33: Variações sazonais de fósforo total na lagoa facultativa referente ao horário T1 (14:00 h) Af $=$ afluente, $\mathrm{S}=$ sub-superfície, $\mathrm{CI}=$ camada intermediária, $\mathrm{AS}=$ interface água-sedimento, $\mathrm{Ef}=$ efluente 


\subsubsection{Amostragem Noturna}

A partir do DGGE realizado com primers para o Domínio Bacteria, de amostra da lagoa facultativa coletada às 02:00 h (T3), foi elaborado o dendrograma da Figura 5.34. Corte arbitrário de $65 \%$ de similaridade foi realizado, sendo observados três agrupamentos principais. No primeiro agrupamento foi verificado $100 \%$ de similaridade entre as distribuições na camada intermediária e interface água-sedimento, na primavera. As distribuições destas profundidades relacionaram-se com $66 \%$ de similaridade com a subsuperfície, na mesma época do ano.

O segundo agrupamento apresentou $100 \%$ de similaridade para a sub-superfície e camada intermediária, no verão; estas por sua vez, relacionaram-se com $87 \%$ de similaridade em relação à interface água-sedimento, na mesma época do ano. Também, foi verificado $100 \%$ de similaridade entre a sub-superfície, a camada intermediária e a interface água-sedimento, no inverno.

O terceiro agrupamento indicou $100 \%$ de similaridade entre a sub-superfície e a camada intermediária, no outono. As distribuições destas profundidades relacionaram-se, com $80 \%$ de similaridade, com a interface água-sedimento, na mesma época do ano.

No horário de coleta das 02:00 h, os valores de $\mathrm{pH}$, temperatura e oxigênio dissolvido na sub-superfície, na primavera, foram de 9,$1 ; 25,2^{\circ} \mathrm{C}$ e $3,4 \mathrm{mg} / \mathrm{L}$, respectivamente. Na camada intermediária, os valores foram de 9,$2 ; 25,1^{\circ} \mathrm{C}$ e $2,7 \mathrm{mg} / \mathrm{L}$, respectivamente. $\mathrm{Na}$ interface água-sedimento, os valores foram iguais a 9,$1 ; 24,8^{\circ} \mathrm{C}$ e 1,3 $\mathrm{mg} / \mathrm{L}$, respectivamente. Foram observadas populações semelhantes de microrganismos (2, 4 e 4 bandas, respectivamente), com similaridades variando de $66 \%$ a $100 \%$. Observou-se diminuição na concentração de oxigênio dissolvido, em ambas as camadas, quando comparado com o valor obtido na sub-superfície. Essa diminuição provavelmente favoreceu o aparecimento de outras populações na camada intermediária e na interface água sedimento.

Os valores de $\mathrm{pH}$, temperatura e oxigênio dissolvido na sub-superfície, no verão, foram de 11,$3 ; 28,7^{\circ} \mathrm{C}$ e $3,2 \mathrm{mg} / \mathrm{L}$, respectivamente. $\mathrm{Na}$ camada intermediária, os valores foram de 9,$9 ; 26,7^{\circ} \mathrm{C}$ e $0,2 \mathrm{mg} / \mathrm{L}$, respectivamente. $\mathrm{Na}$ interface água-sedimento, os valores foram de 9,$7 ; 25,5^{\circ} \mathrm{C}$ e $0,08 \mathrm{mg} / \mathrm{L}$, respectivamente. Os parâmetros físico-químicos 
verificados na sub-superfície e na camada intermediária permitiram o crescimento, em ambas as profundidades, de populações similares de microrganismos (13 bandas), com similaridade de $100 \%$. Valores ligeiramente menores, verificados na interface água sedimento, possivelmente contribuíram para o menor número de bandas encontrados nessa profundidade (11 bandas).

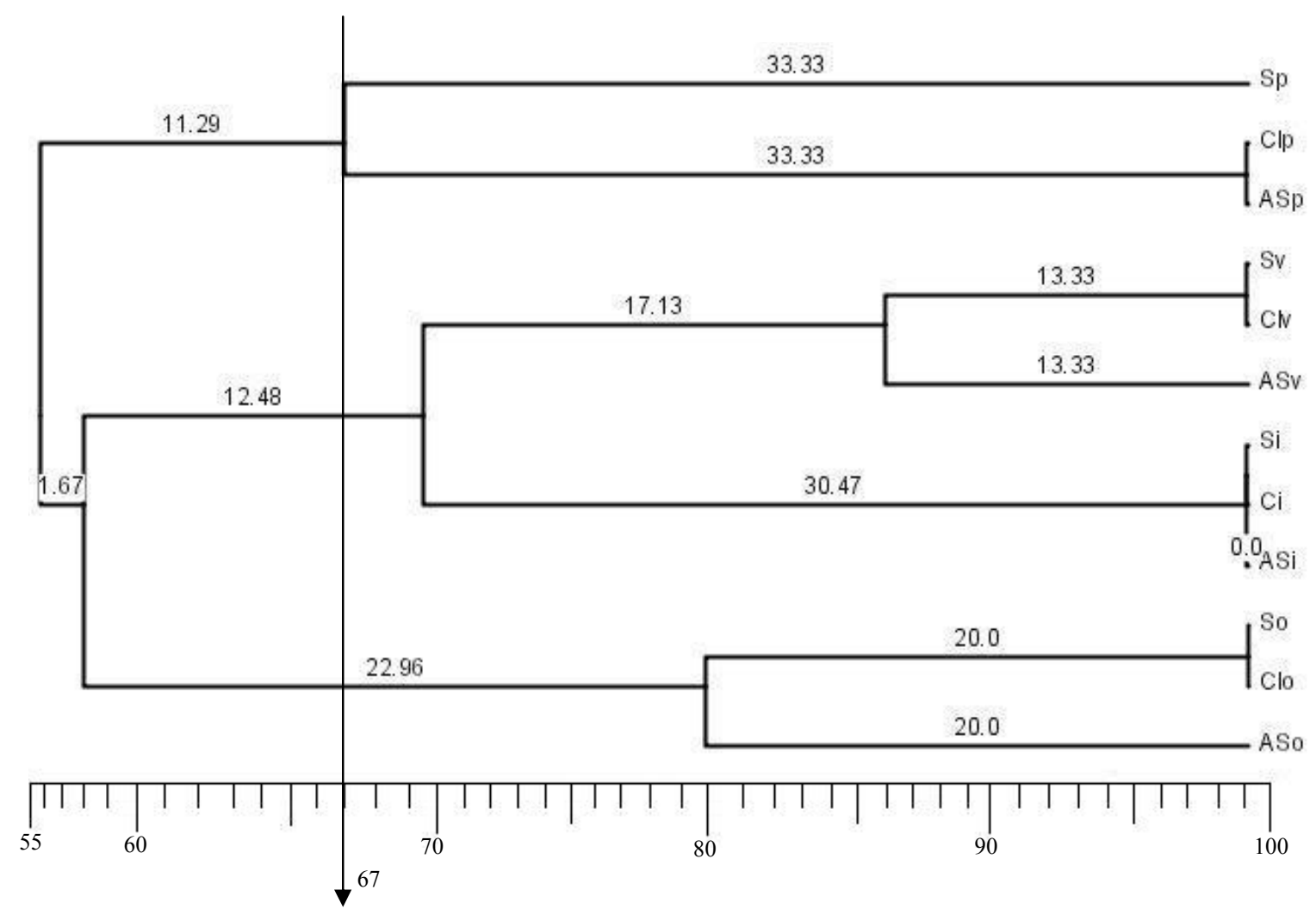

Figura 5.34: Dendrograma das variações sazonais na lagoa facultativa com primers para o Domínio Bacteria referente ao horário T3 $(02: 00 \mathrm{~h})$.

$\mathrm{S}=$ sub-superfície, $\mathrm{CI}=$ camada intermediária, $\mathrm{AS}=$ interface água-sedimento. A régua indica porcentagens do coeficiente de similaridade

Os valores de $\mathrm{pH}$, temperatura e oxigênio dissolvido na sub-superfície, no inverno, foram de 10,$2 ; 20,8^{\circ} \mathrm{C}$ e $6,6 \mathrm{mg} / \mathrm{L}$, respectivamente. $\mathrm{Na}$ camada intermediária, os valores foram de 10,$0 ; 19,8^{\circ} \mathrm{C}$ e $3,0 \mathrm{mg} / \mathrm{L}$, respectivamente. $\mathrm{Na}$ interface água-sedimento, os valores foram de 9,$8 ; 19,6^{\circ} \mathrm{C}$ e $0,5 \mathrm{mg} / \mathrm{L}$, respectivamente. Foram observadas populações semelhantes de microrganismos nessas profundidades; ou seja, com 10, 10 e 10 bandas, respectivamente, e similaridade de $100 \%$. Tal semelhança indica, provavelmente, a 
versatilidade metabólica das bactérias capazes de manterem-se em condições aeróbias $(6,6$, $\mathrm{mg} / \mathrm{L}$ na sub-superfície) e facultativas $(3,0 \mathrm{mg} / \mathrm{L}$ e $0,5 \mathrm{mg} / \mathrm{L}$, respectivamente, para a camada intermediária e interface água sedimento).

Os valores de $\mathrm{pH}$, temperatura e oxigênio dissolvido na sub-superfície, no outono, foram de 8,$3 ; 30,6^{\circ} \mathrm{C}$ e $2,3 \mathrm{mg} / \mathrm{L}$, respectivamente. Na camada intermediária, os valores foram de 8,$1 ; 28,6^{\circ} \mathrm{C}$ e $0,07 \mathrm{mg} / \mathrm{L}$, respectivamente. Na interface água-sedimento, os valores foram iguais a 7,$4 ; 27,8^{\circ} \mathrm{C}$ e $0,3 \mathrm{mg} / \mathrm{L}$, respectivamente. Os valores maiores de $\mathrm{pH}$ e temperatura que foram observados na sub-superfície e na camada intermediária, quando comparados com os da interface água-sedimento, possivelmente contribuíram para o aparecimento de maior número de bandas naqueles pontos de coleta ( 8 e 8 bandas, respectivamente, enquanto só 6 bandas foram registradas para a interface água-sedimento). Os coeficientes de similaridade variaram de $80 \%$ a $100 \%$.

Os valores do $\mathrm{pH}$, no horário das 02:00 h, na sub-superfície e camada intermediária, no verão, foram de 11,3 e 9,9, respectivamente. Sob condições de $\mathrm{pH}$ alcalino foi verificada maior diversidade de bactérias (13 e 13 bandas, respectivamente), nessa época e nesse horário particular. As menores diversidades observadas na sub-superfície, na primavera (2 bandas), ocorreram quando o valor de $\mathrm{pH}$ foi de 9,1 . O valor mínimo de $\mathrm{pH}$ foi de 7,4 no outono, e máximo de 11,3 no verão (Figura 5.35). O pH afluente variou de 7,0 no outono, a 9,4 no verão (Anexos B4, B10, B16 e B22).

Granado (2004) verificou valores menores de $\mathrm{pH}$ na superfície da lagoa facultativa 1, no horário das 03:00 h, variando de 6,5 no outono, a 7,3 na primavera. $\mathrm{Na}$ lagoa facultativa 2 , os valores foram de 6,9 no inverno, a 8,1 no verão. 


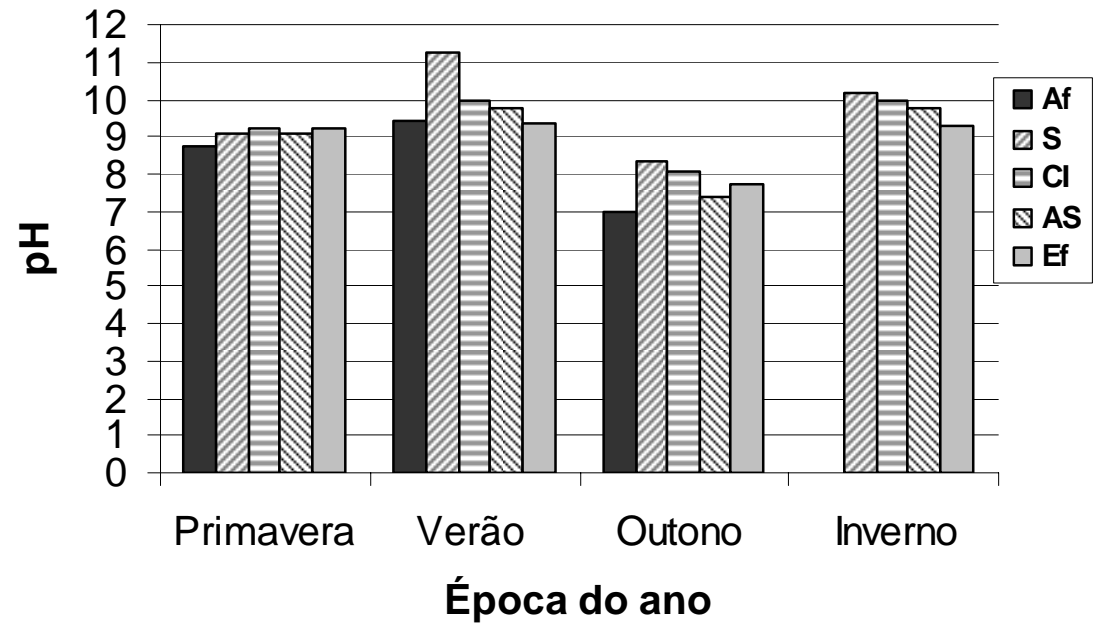

Figura 5.35: Variações sazonais de pH na lagoa facultativa referente ao horário T3 (02:00 h) $\mathrm{Af}=$ afluente, $\mathrm{S}=$ sub-superfície, $\mathrm{CI}=$ camada intermediária, $\mathrm{AS}=$ interface água-sedimento, $\mathrm{Ef}=$ efluente

Os valores de temperatura, no horário das 02:00 h, obtidos na sub-superfície e na camada intermediária, no verão, foram de $28,7^{\circ} \mathrm{C}$ e $26,7^{\circ} \mathrm{C}$, respectivamente. A temperatura, na sub-superfície, na primavera, foi de $25,2^{\circ} \mathrm{C}$. Possivelmente, a temperatura maior verificada no verão o favoreceu desenvolvimento dos microrganismos nessa época do ano, assim como foi verificado no outono, no horário das 14:00 h. Os valores de temperatura, nas quatro épocas do ano, oscilaram na faixa de $19,6^{\circ} \mathrm{C}$ no inverno, a $30,6^{\circ} \mathrm{C}$ no outono (Figura 5.36). A temperatura afluente variou de $24,0^{\circ} \mathrm{C}$ na primavera, a $27,8^{\circ} \mathrm{C}$ no outono (Anexos B4, B10, B16 e B22). Granado (2004) verificou, no horário das 03:00 h, na superfície da lagoa facultativa 1 , valores similares de temperatura; ou seja, de $23,4^{\circ} \mathrm{C}$ no inverno, a $30,6^{\circ} \mathrm{C}$ no verão. Na lagoa facultativa 2 , foram de $23,3^{\circ} \mathrm{C}$ no inverno, a $30,8^{\circ} \mathrm{C}$ no verão. 


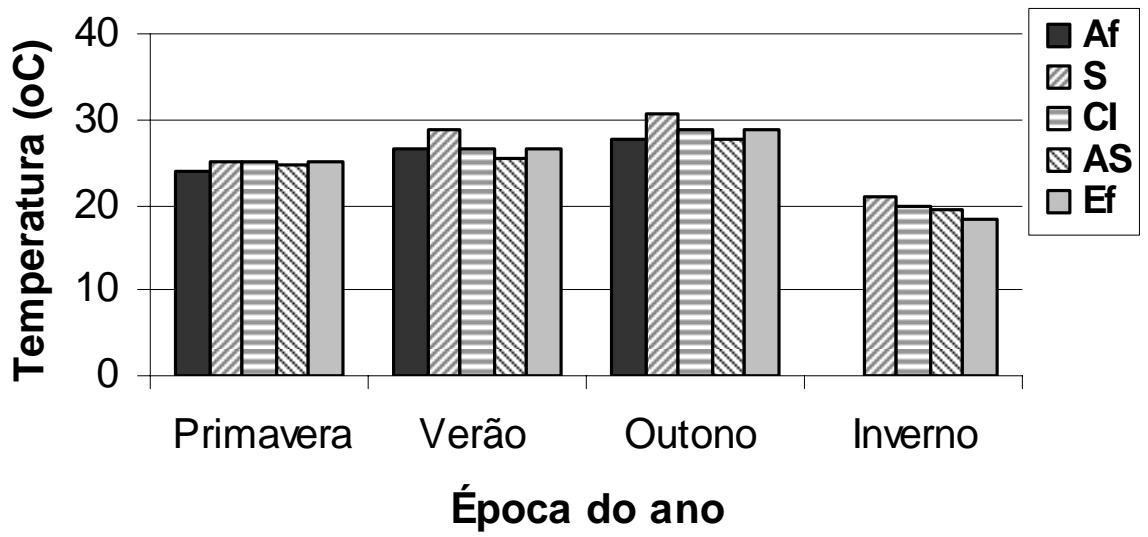

Figura 5.36: Variações sazonais de temperatura na lagoa facultativa referente ao horário T3 (02:00 h)

$\mathrm{Af}=$ afluente, $\mathrm{S}=$ sub-superfície, $\mathrm{CI}=$ camada intermediária, $\mathrm{AS}=$ interface água-sedimento, $\mathrm{Ef}=$ efluente

As concentrações de oxigênio dissolvido, encontradas no horário das 02:00 h, na sub-superfície e na camada intermediária, no verão, foram de $3,2 \mathrm{mg} / \mathrm{L}$ e $0,23 \mathrm{mg} / \mathrm{L}$, respectivamente. $\mathrm{Na}$ sub-superfície, na primavera, o valor foi de $3,2 \mathrm{mg} / \mathrm{L}$. Concentrações mínima de $0,03 \mathrm{mg} / \mathrm{L}$, e máxima de $6,2 \mathrm{mg} / \mathrm{L}$ foram registradas no outono e no inverno, respectivamente (Figura 5.37). No afluente, esta variou de $0,2 \mathrm{mg} / \mathrm{L}$ na primavera, a 2,0 $\mathrm{mg} / \mathrm{L}$ no outono. As concentrações verificadas foram variáveis durante as estações do ano, assim como nas diferentes profundidades (Anexos B4, B10, B16 e B22).

Granado (2004) verificou concentrações similares de oxigênio dissolvido na superfície, no horário das 03:00 h, na lagoa facultativa 1 , variando de $0,1 \mathrm{mg} / \mathrm{L}$, no verão, inverno e primavera, a 2,0 mg/L, no outono. Na lagoa facultativa 2, variou de $0,0 \mathrm{mg} / \mathrm{L}$ no verão, a $5,8 \mathrm{mg} / \mathrm{L}$ no outono. 


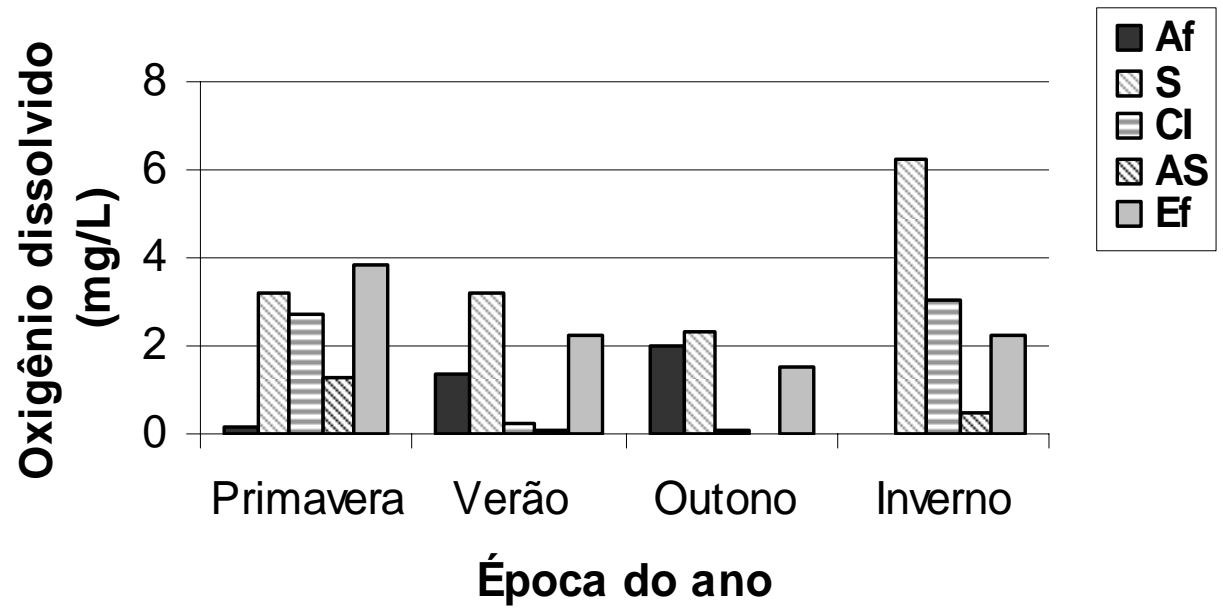

Figura 5.37: Variações sazonais de oxigênio dissolvido na lagoa facultativa referente ao horário T3 $(02: 00 \mathrm{~h})$

$\mathrm{Af}=$ afluente, $\mathrm{S}=$ sub-superfície, $\mathrm{CI}=$ camada intermediária, $\mathrm{AS}=$ interface água-sedimento, $\mathrm{Ef}=$ efluente

As concentrações de sulfato, no horário das 02:00 h, na sub-superfície e camada intermediária, no verão, foram de $11,0 \mathrm{mg} / \mathrm{L}$ e $14,0 \mathrm{mg} / \mathrm{L}$, respectivamente. $\mathrm{Na}$ subsuperfície, na primavera, foi de 15,0 mg/L. Apesar desses valores similares de sulfato, a diversidade de bactérias (13, 13 e 2 bandas, respectivamente) foi diferente nas duas estações do ano, possivelmente devido a outros fatores. Concentrações mínima de $0,0 \mathrm{mg} / \mathrm{L}$ e máxima de 19,0 mg/L foram verificadas no outono e na primavera, respectivamente. No afluente, variou de 1,0 mg/L no outono, a 16,0 mg/L no verão (Figura 5.38). Essas concentrações foram menores em relação às verificadas na lagoa anaeróbia (Anexos B4, B10, B16 e B22). 


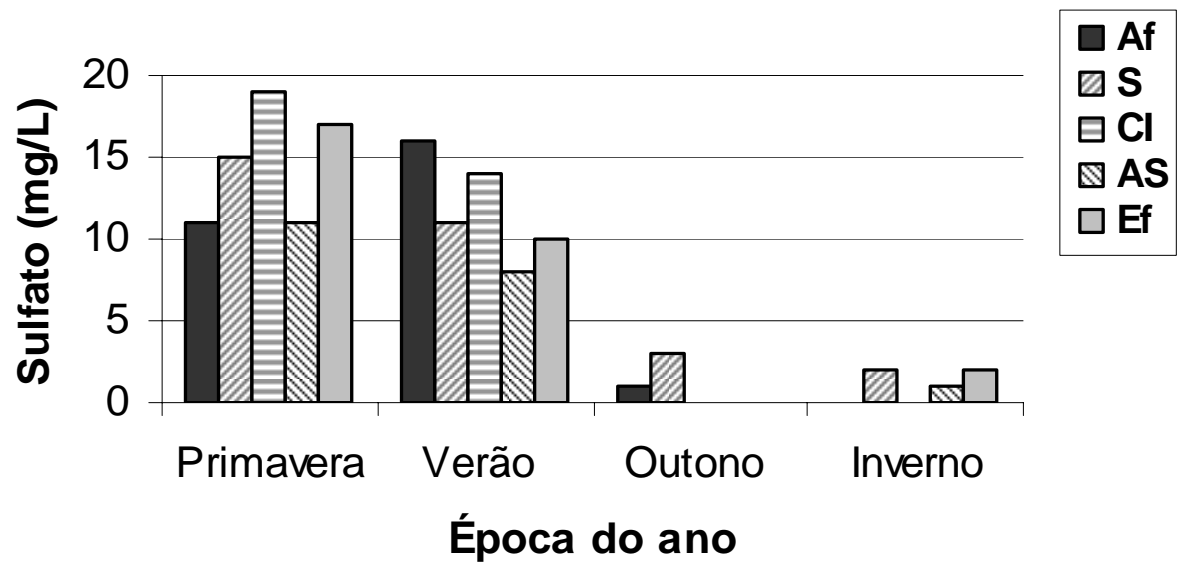

Figura 5.38: Variações sazonais de sulfato na lagoa facultativa referente ao horário T3 $(02: 00 \mathrm{~h})$ $\mathrm{Af}=$ afluente, $\mathrm{S}=$ sub-superfície, $\mathrm{CI}=$ camada intermediária, $\mathrm{AS}=$ interface água-sedimento, $\mathrm{Ef}=$ efluente

Os valores da matéria orgânica bruta $\left(\mathrm{DQO}_{\mathrm{b}}\right)$ no horário das 02:00 h, na subsuperfície e camada intermediária, no verão, foram de 133,0 mg/L e 124,0 mg/L, respectivamente. Na sub-superfície, na primavera, foi de 132,0 mg/L. Apesar dos valores similares de $\mathrm{DQO}_{\mathrm{b}}$ encontrados, foram observadas diversidades de bactérias distintas, em ambas as épocas do ano (13, 13 e 2 bandas, respectivamente). Concentrações mínima de $121,3 \mathrm{mg} / \mathrm{L}$ e máxima de $306,6 \mathrm{mg} / \mathrm{L}$ foram verificadas no outono e inverno, respectivamente. No afluente, variou de $87,0 \mathrm{mg} / \mathrm{L}$ na primavera, a $134,7 \mathrm{mg} / \mathrm{L}$ no outono (Figura 5.39). Foram observadas poucas variações nas diferentes profundidades da lagoa, exceto no inverno, quando as concentrações foram próximas a 300,4 mg/L (Anexos B4, B10, B16 e B22). No efluente final, a DQO variou de 100,2 mg/L no outono, a 160,0 mg/L no verão. Esses valores estiveram abaixo do recomendado por Andrade Neto (1997), para lagoas de estabilização, os quais devem estar compreendidos entre 200-300 mg/L. 


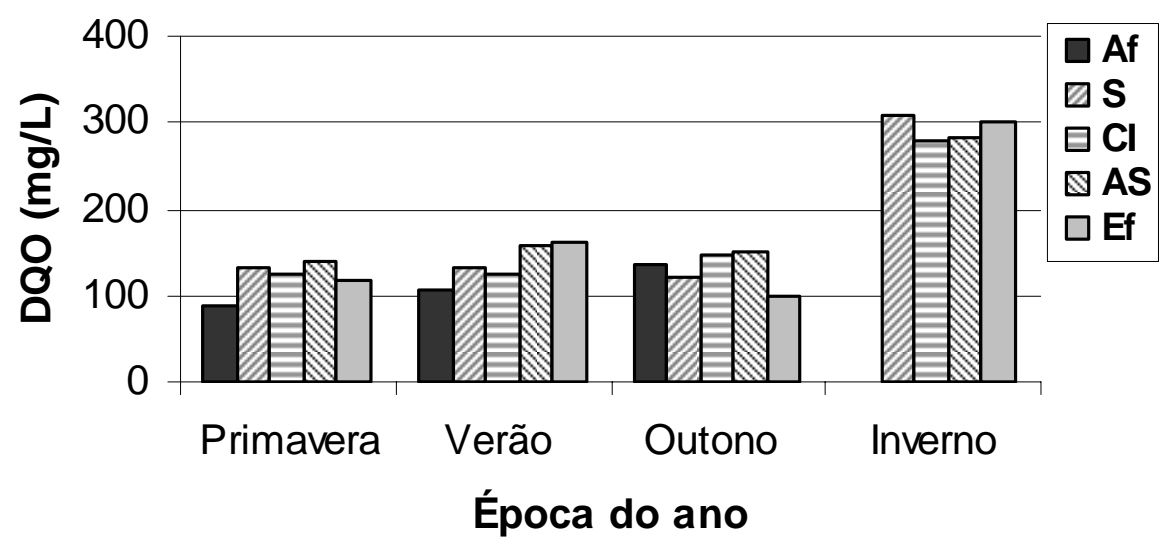

Figura 5.39: Variações sazonais de matéria orgânica na lagoa facultativa referente ao horário T3 $(02: 00 \mathrm{~h})$

$\mathrm{Af}=$ afluente, $\mathrm{S}=$ sub-superfície, $\mathrm{CI}=$ camada intermediária, $\mathrm{AS}=$ interface água-sedimento, $\mathrm{Ef}=$ efluente

As concentrações de sólidos suspensos voláteis encontrados no horário das 02:00 h, na sub-superfície e na camada intermediária, no verão, foram de $57,0 \mathrm{mg} / \mathrm{L}$ e $80,0 \mathrm{mg} / \mathrm{L}$, respectivamente. Na sub-superfície, na primavera, foi de 126,0 mg/L. Assim como o que foi verificado na lagoa anaeróbia, o maior valor observado na primavera pode ser devido à presença de outros microrganismos, tais como algas e protozoários, os quais contribuíram nesse acréscimo de sólidos suspensos voláteis. Uma concentração mínima de $0,0 \mathrm{mg} / \mathrm{L}$ foi verificada no verão e no inverno, e um valor máximo de 146,0 mg/L, na primavera (Figura 5.40). No afluente, variou de $6,0 \mathrm{mg} / \mathrm{L}$ na primavera, a $90,0 \mathrm{mg} / \mathrm{L}$ no outono. Assim como foi observado na lagoa anaeróbia, na primavera foram verificadas maiores concentrações de sólidos suspensos voláteis, quando comparadas com as obtidas em outras épocas do ano (Anexos B4, B10, B16 e B22). 


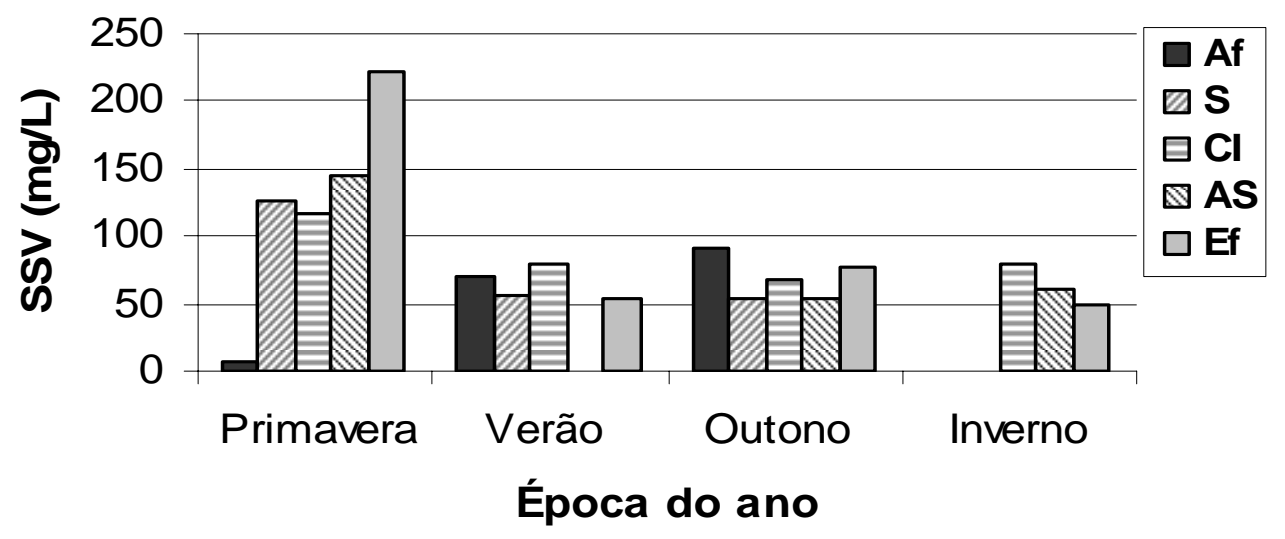

Figura 5.40: Variações sazonais de SSV na lagoa facultativa referente ao horário T3 $(02: 00 \mathrm{~h})$ $\mathrm{Af}=$ afluente, $\mathrm{S}$ = sub-superfície, $\mathrm{CI}=$ camada intermediária, $\mathrm{AS}=$ interface água-sedimento, $\mathrm{Ef}=$ efluente

As concentrações de NTK no horário das 02:00 h, na sub-superfície e camada intermediária, no verão, foram de $10,5 \mathrm{mg} / \mathrm{L}$ e $10,0 \mathrm{mg} / \mathrm{L}$, respectivamente. $\mathrm{Na}$ subsuperfície, na primavera, foi de $31,6 \mathrm{mg} / \mathrm{L}$. Esses valores menores verificados no verão podem ser decorrentes da maior remoção de nitrogênio pelos microrganismos presentes na lagoa, os quais por sua vez encontraram-se em maior diversidade (13 e 13 bandas, respectivamente) nesse horário e época do ano. O valor mínimo foi de 9,2 mg/L no inverno, e máximo de $31,6 \mathrm{mg} / \mathrm{L}$ na primavera (Figura 5.41). No afluente, variou de $28,0 \mathrm{mg} / \mathrm{L}$ na primavera, a 10,7 mg/L no verão. Na primavera foram obtidas as maiores concentrações, quando comparadas com aquelas encontradas em outras épocas do ano, assim como foi observado na lagoa anaeróbia (Anexos B5, B11, B17 e B23).

As concentrações de nitrito, no horário das 02:00 h, na sub-superfície e camada intermediária, no verão, foram de $30,4 \mu \mathrm{g} / \mathrm{L}$ e $11,4 \mu \mathrm{g} / \mathrm{L}$, respectivamente. $\mathrm{Na}$ subsuperfície, na primavera, foi de 2,0 $\mu \mathrm{g} / \mathrm{L}$. As concentrações de nitrato, foram de $1,8 \mathrm{mg} / \mathrm{L}$ e $1,2 \mathrm{mg} / \mathrm{L}$, respectivamente. Na sub-superfície, na primavera, foi de 1,2 mg/L.

Granado (2004) verificou valores superiores de NTK na superfície da lagoa facultativa 1, no outono, no horário das $03: 00 \mathrm{~h}$, de $54,8 \mathrm{mg} / \mathrm{L}$; nitrito de $0,003 \mathrm{mg} / \mathrm{L}$; nitrato de 2,4 mg/L, e nitrogênio amoniacal de 36,0 mg/L. Na lagoa facultativa 2 , os valores foram de 100,5 mg/L; 0,003 mg/L; 2,5 mg/L, e 33,2 mg/L, respectivamente. 


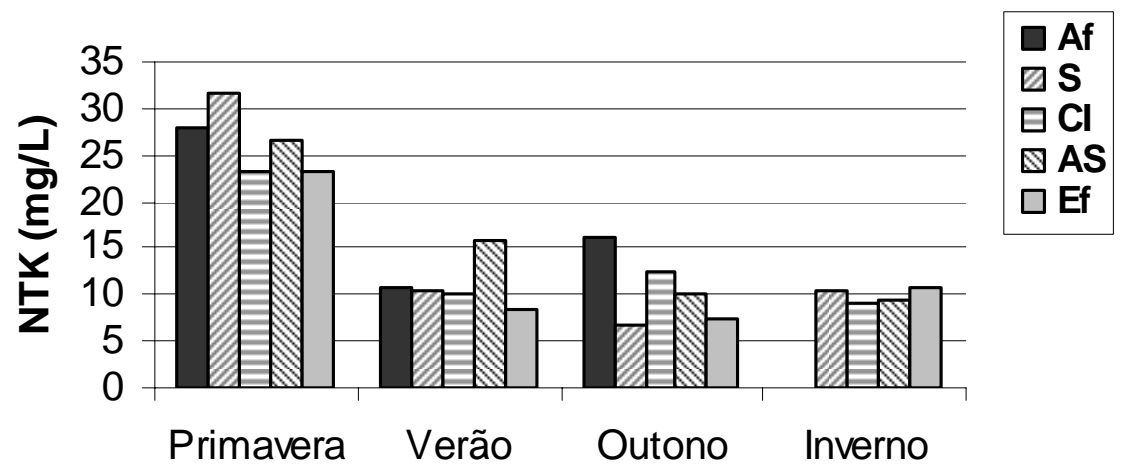

\section{Época do ano}

Figura 5.41: Variações sazonais de NTK na lagoa facultativa referente ao horário T3 $(02: 00 \mathrm{~h})$ Af $=$ afluente, $\mathrm{S}=$ sub-superfície, $\mathrm{CI}=$ camada intermediária, $\mathrm{AS}=$ interface água-sedimento, $\mathrm{Ef}=$ efluente

As concentrações de fósforo total encontradas no horário das 02:00 h, na subsuperfície e camada intermediária, no verão, foram de $1,7 \mathrm{mg} / \mathrm{L}$ e $1,5 \mathrm{mg} / \mathrm{L}$, respectivamente. $\mathrm{Na}$ sub-superfície, na primavera, foi de 4,2 mg/L. Esses valores menores, verificados no verão, podem ter sido causados pela maior remoção de fósforo total pelos microrganismos presentes na lagoa (em maior diversidade nessa época do ano, com 13 e 13 bandas, respectivamente). Concentrações mínima de 1,4 mg/L e máxima de 5,6 $\mathrm{mg} / \mathrm{L}$ foram verificadas no outono. No afluente, variou de $1,5 \mathrm{mg} / \mathrm{L}$ na primavera, a $4,15 \mathrm{mg} / \mathrm{L}$ no outono (Figura 5.42) (Anexos B5, B11, B17 e B23).

As concentrações de ortofosfato, no horário das 02:00 h, na sub-superfície e camada intermediária, no verão, foram de $0,6 \mathrm{mg} / \mathrm{L}$ e $0,6 \mathrm{mg} / \mathrm{L}$, respectivamente. Na sub-superfície, na primavera, foi de $0,2 \mathrm{mg} / \mathrm{L}$.

Granado (2004) verificou concentração superior de ortofosfato na superfície da lagoa facultativa 1, no horário das 03:00 h, no outono, de 4,97 mg/L; e de 16,4 mg/L de fósforo total. $\mathrm{Na}$ lagoa facultativa 2, os valores de ortofosfato foram de 4,28 mg/L e de 16,9 $\mathrm{mg} / \mathrm{L}$ de fósforo total. 


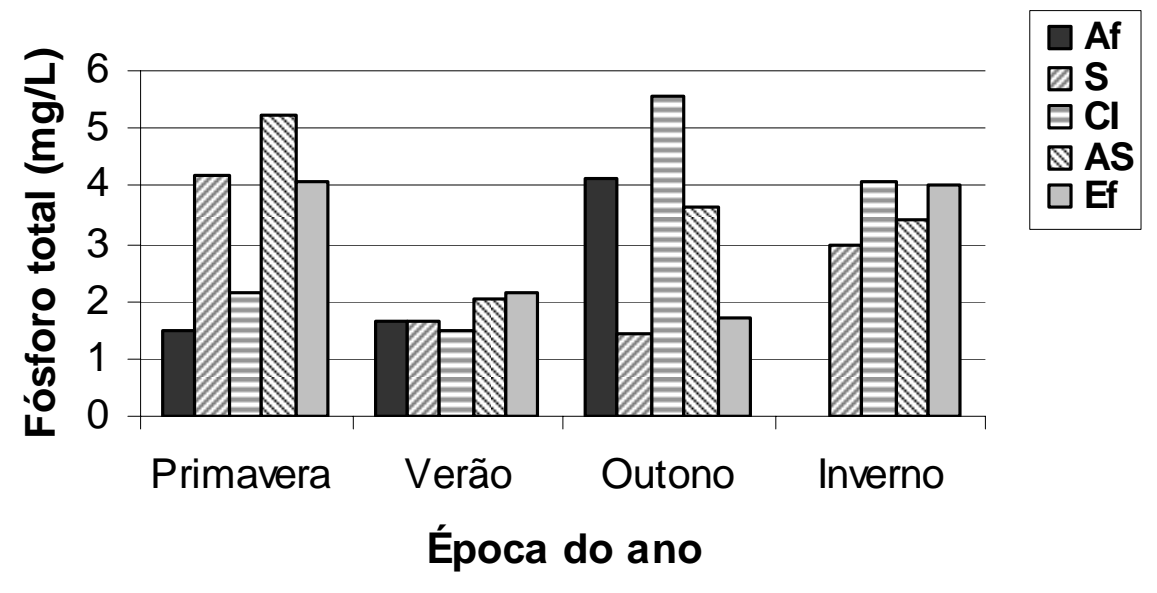

Figura 5.42: Variações sazonais de fósforo total na lagoa facultativa referente ao horário T3 (02:00 h)

$\mathrm{Af}=$ afluente, $\mathrm{S}=$ sub-superfície, $\mathrm{CI}=$ camada intermediária, $\mathrm{AS}=$ interface água-sedimento, $\mathrm{Ef}=$ efluente

Segundo Andrade Neto (1997), no efluente final de lagoas de estabilização, a faixa de valores de DQO deve compreender entre $200-300 \mathrm{mg} / \mathrm{L}$, NTK entre $28-45 \mathrm{mg} / \mathrm{L}$ e de fósforo total entre 4,5-6,9 mg/L. Na presente pesquisa, foram encontradas concentrações de matéria orgânica abaixo dessa faixa, exceto no inverno, atingindo 300,4 mg/L, no horário T3. Os valores de NTK também estiveram abaixo dessa faixa, exceto na primavera, com $28,7 \mathrm{mg} / \mathrm{L}$, no horário $\mathrm{T} 1$. Os valores de fósforo total foram menores do que os recomendados por Andrade Neto (1997).

Raras são as pesquisas realizadas sobre a avaliação da diversidade temporal da comunidade de bácterias existentes em lagoas de estabilização. Assim, pouco se conhece sobre sua variabilidade na coluna da água e suas inter-relações sob as condições nutricionais próprias do sistema.

$\mathrm{Na}$ presente pesquisa, as condições nutricionais verificadas nas diferentes coletas realizadas e pontos de amostragem, favoreceram, possivelmente, desenvolvimento de microrganismos anaeróbios, anaeróbios facultativos, microaerófilos e aeróbios. Com relação à temperatura, favoreceram desenvolvimento de microrganismos psicrofílicos, no inverno, e mesofílicos, nas outras épocas do ano. As variações dos valores de $\mathrm{pH}$ observados nas lagoas sugerem presença de microrganismos neutrófilos e alcalófilos. 
Avaliando os resultados obtidos com relação aos nutrientes, tais como nitrogênio amoniacal, nitrito e nitrato, a maior temperatura verificada no outono favoreceu uma maior atividade metabólica, assim como uma maior velocidade de oxidação do nitrogênio amoniacal. Quase todo o nitrogênio amoniacal foi oxidado a nitrato na lagoa facultativa. A concentração de oxigênio dissolvido não foi limitante à atividade nitrificante, quando associada às maiores temperaturas registradas nos períodos de verão e outono.

Observou-se, também, que na lagoa anaeróbia as concentrações de nitrogênio amoniacal foram mais elevadas do que na lagoa facultativa, em todos os períodos estudados, associadas à maior carga orgânica e ao processo de amonificação que ocorre no ambiente anaeróbio. Por outro lado, a atividade nitrificante foi maior na lagoa facultativa, principalmente nos períodos de verão e outono, possivelmente vinculada aos aumentos da temperatura e da biomassa algal (produção primária) e, conseqüentemente, à maior oxigenação do meio. Nesses períodos observou-se que quase todo o nitrogênio amoniacal foi oxidado a nitrato na lagoa facultativa, o que não foi observado na lagoa anaeróbia. Portando, nos períodos de verão e outono, possivelmente tenha havido um aumento da população de bactérias, tanto de autótrofos (inclusive nitrificantes) como de heterótrofos, $o$ que foi confirmado pela maior diversidade do Domínio Bacteria no perfil de bandas padrões do DGGE. 


\subsubsection{Diversidade das bactérias fototróficas púrpuras}

A partir do DGGE realizado com primers pufM.557FGC e 750R, de amostra da lagoa facultativa coletada às 14:00 h (T1), foi elaborado o dendrograma da Figura 5.43. Corte arbitrário de $62 \%$ de similaridade foi realizado, sendo observados três agrupamentos principais. $\mathrm{O}$ primeiro agrupamento indicou que as estruturas da comunidade de bactérias foram semelhantes na primavera e verão, nas diferentes profundidades, apresentando similaridade de $100 \%$. No segundo agrupamento, foi observada uma similaridade de $100 \%$, no outono, para as diferentes profundidades; assim como foi encontrada para a camada intermediária e a interface água sedimento, no inverno. O terceiro agrupamento mostrou similaridade de 54\% em relação à sub-superfície, no inverno, com os dois agrupamentos mencionados anteriormente.

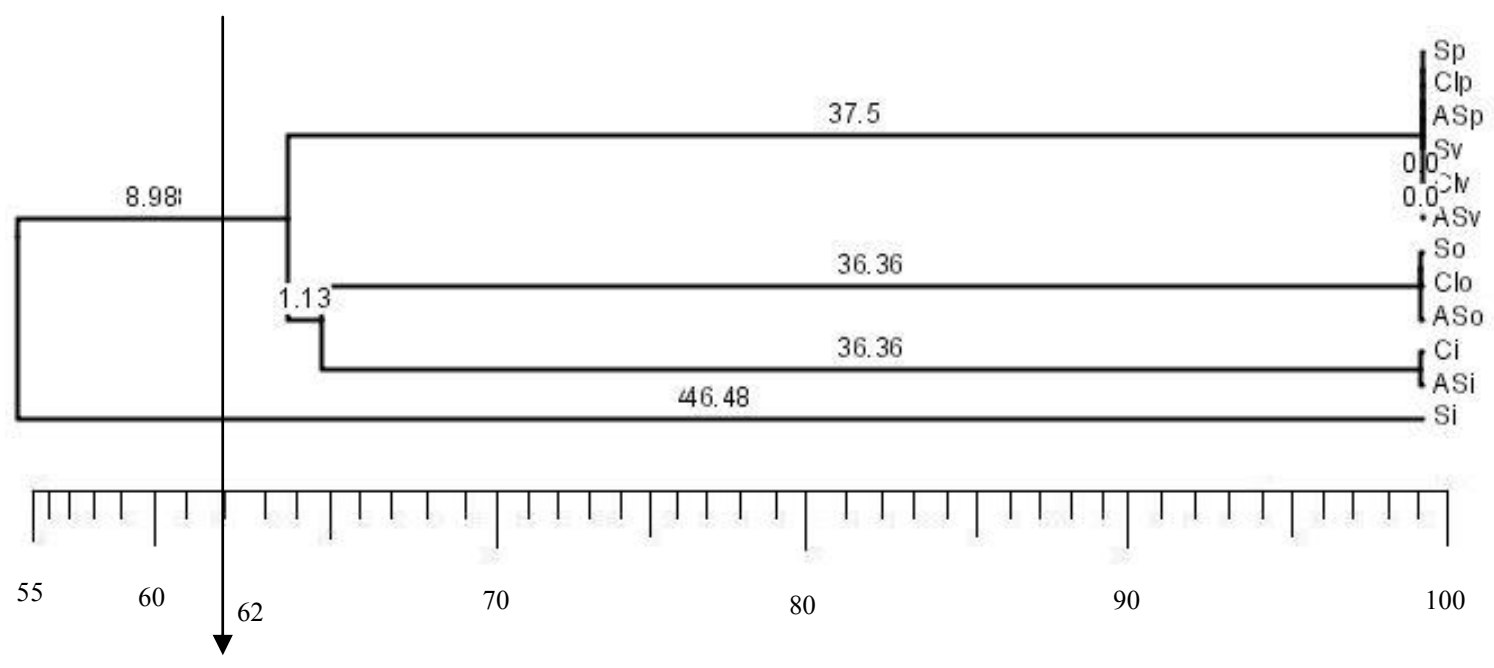

Figura 5.43: Dendrograma das variações sazonais na lagoa facultativa com primers pufM referente ao horário $\mathrm{T} 1(14: 00 \mathrm{~h})$

$\mathrm{S}=$ sub-superfície, $\mathrm{CI}=$ camada intermediária, $\mathrm{AS}=$ interface água-sedimento. A régua indica porcentagens do coeficiente de similaridade 
A intensidade luminosa no horário de coleta das 14:00 h, na superfície da lagoa, na primavera, foi de $221,3 \mu \mathrm{Em}^{-2} \mathrm{~s}^{-1}$. Os valores de $\mathrm{pH}$, temperatura e oxigênio dissolvido na sub-superfície, foram de 8,$8 ; 23,5^{\circ} \mathrm{C}$ e $0,3 \mathrm{mg} / \mathrm{L}$, respectivamente. Na camada intermediária, os valores foram de 9,$0 ; 23,4^{\circ} \mathrm{C}$ e $0,3 \mathrm{mg} / \mathrm{L}$, respectivamente. Na interface água-sedimento, os valores foram iguais a 9,$1 ; 23,3^{\circ} \mathrm{C}$ e $0,05 \mathrm{mg} / \mathrm{L}$, respectivamente.

A intensidade luminosa na superfície da lagoa, no verão, foi de $1.344 \mu \mathrm{Em}^{-2} \mathrm{~s}^{-1}$. Os valores de $\mathrm{pH}$, temperatura e oxigênio dissolvido na sub-superfície, foram de 12,$0 ; 32,1^{\circ} \mathrm{C}$ e $9,5 \mathrm{mg} / \mathrm{L}$, respectivamente. $\mathrm{Na}$ camada intermediária, os valores foram de 9,$5 ; 26,1^{\circ} \mathrm{C}$ e $0,02 \mathrm{mg} / \mathrm{L}$, respectivamente. $\mathrm{Na}$ interface água-sedimento, os valores foram de 10,0; $25,4^{\circ} \mathrm{C}$ e $0,11 \mathrm{mg} / \mathrm{L}$, respectivamente. Foram verificadas 2 bandas similares no verão, nas diferentes profundidades, respectivamente, indicando que as bactérias fototróficas púrpuras desenvolveram-se sob condições físico-químicos diferentes. As similaridades observadas foram de $100 \%$.

A intensidade luminosa na superfície da lagoa, no outono, foi $409,9 \mu \mathrm{Em}^{-2} \mathrm{~s}^{-1}$. Os valores de $\mathrm{pH}$, temperatura e oxigênio dissolvido, na sub-superfície, foram 10,$0 ; 34,3^{\circ} \mathrm{C} \mathrm{e}$ 7,2 mg/L. Na camada intermediária, os valores foram de 9,$3 ; 27,5^{\circ} \mathrm{C}$ e $1,1 \mathrm{mg} / \mathrm{L}$, respectivamente. Com essa intensidade luminosa verificada na superfície da lagoa facultativa no outono, superior ao da primavera (2 bandas), e inferior ao do verão (2 bandas), foi observado maior número de bandas no DGGE (5 bandas), quando comparado com os daquelas duas épocas do ano. O coeficiente de similaridade, no outono, foi de $100 \%$.

A intensidade luminosa na superfície da lagoa, no inverno, foi $519,8 \mu \mathrm{Em}^{-2} \mathrm{~s}^{-1}$. Os valores de $\mathrm{pH}$, temperatura e oxigênio dissolvido na sub-superfície, foram de 10,$3 ; 20,1^{\circ} \mathrm{C}$ e $5,6 \mathrm{mg} / \mathrm{L}$. Na camada intermediária, os valores foram de 10,$1 ; 19,8^{\circ} \mathrm{C}$ e $4,4 \mathrm{mg} / \mathrm{L}$, respectivamente. $\mathrm{Na}$ interface água-sedimento, os valores foram de 10,$0 ; 19,6^{\circ} \mathrm{C}$ e 2,9 $\mathrm{mg} / \mathrm{L}$, respectivamente. Foram verificadas 2 bandas na amostra da sub-superfície da lagoa, no perfil do DGGE. Essa intensidade luminosa foi superior à verificada no outono, e assim constatou-se menor número de bandas no DGGE. Todavia, nesse período as lagoas não se encontravam em operação, o que provavelmente favoreceu a ocorrência desta menor diversidade. Similaridade de $100 \%$ foi observada para a camada intermediária e interface água-sedimento. 
A partir do DGGE realizado com primers pufM.557FGC e 750R, de amostra da lagoa facultativa, coletada às 02:00 h (T3), foi elaborado o dendrograma da Figura 5.44. Corte arbitrário de $63 \%$ de similaridade foi realizado, sendo observados três agrupamentos principais. O primeiro agrupamento indicou que as distribuições das bactérias fototróficas púrpuras, na primavera e outono apresentaram 100\% de similaridade nas diferentes profundidades. O segundo agrupamento indicou, também, 100\% de similaridade nas diferentes profundidades, no verão, e 70\% de similaridade com a sub-superfície e a camada intermediária, no inverno. O terceiro agrupamento, que correspondeu à interface águasedimento, no inverno, foi similar em 54\% aos agrupamentos anteriormente mencionados.

No horário de coleta das 02:00 h, os valores de $\mathrm{pH}$, temperatura e oxigênio dissolvido encontrados na sub-superfície, na primavera, foram de 9,$1 ; 25,2^{\circ} \mathrm{C}$ e $3,2 \mathrm{mg} / \mathrm{L}$, respectivamente. $\mathrm{Na}$ camada intermediária, os valores foram de 9,$2 ; 25,1^{\circ} \mathrm{C}$ e $2,7 \mathrm{mg} / \mathrm{L}$, respectivamente. Na interface água-sedimento, os valores foram de 9,$1 ; 24,8^{\circ} \mathrm{C}$ e $1,3 \mathrm{mg} / \mathrm{L}$, respectivamente. Os valores de $\mathrm{pH}$, temperatura e oxigênio dissolvido na sub-superfície, no outono, foram de 8,$3 ; 30,6^{\circ} \mathrm{C}$ e $2,3 \mathrm{mg} / \mathrm{L}$, respectivamente. Na camada intermediária, os valores foram de 8,$1 ; 28,6^{\circ} \mathrm{C}$ e $0,07 \mathrm{mg} / \mathrm{L}$, respectivamente. Na interface água-sedimento, os valores foram iguais a 7,$4 ; 27,8^{\circ} \mathrm{C}$ e $0,3 \mathrm{mg} / \mathrm{L}$, respectivamente. Os valores de $\mathrm{pH}$ verificados na primavera foram superiores aos observados no outono. Na primavera foi observada menor diversidade de bactérias fototróficas púrpuras (4 bandas). No outono foram verificadas 6 bandas no DGGE e similaridade de $100 \%$. 


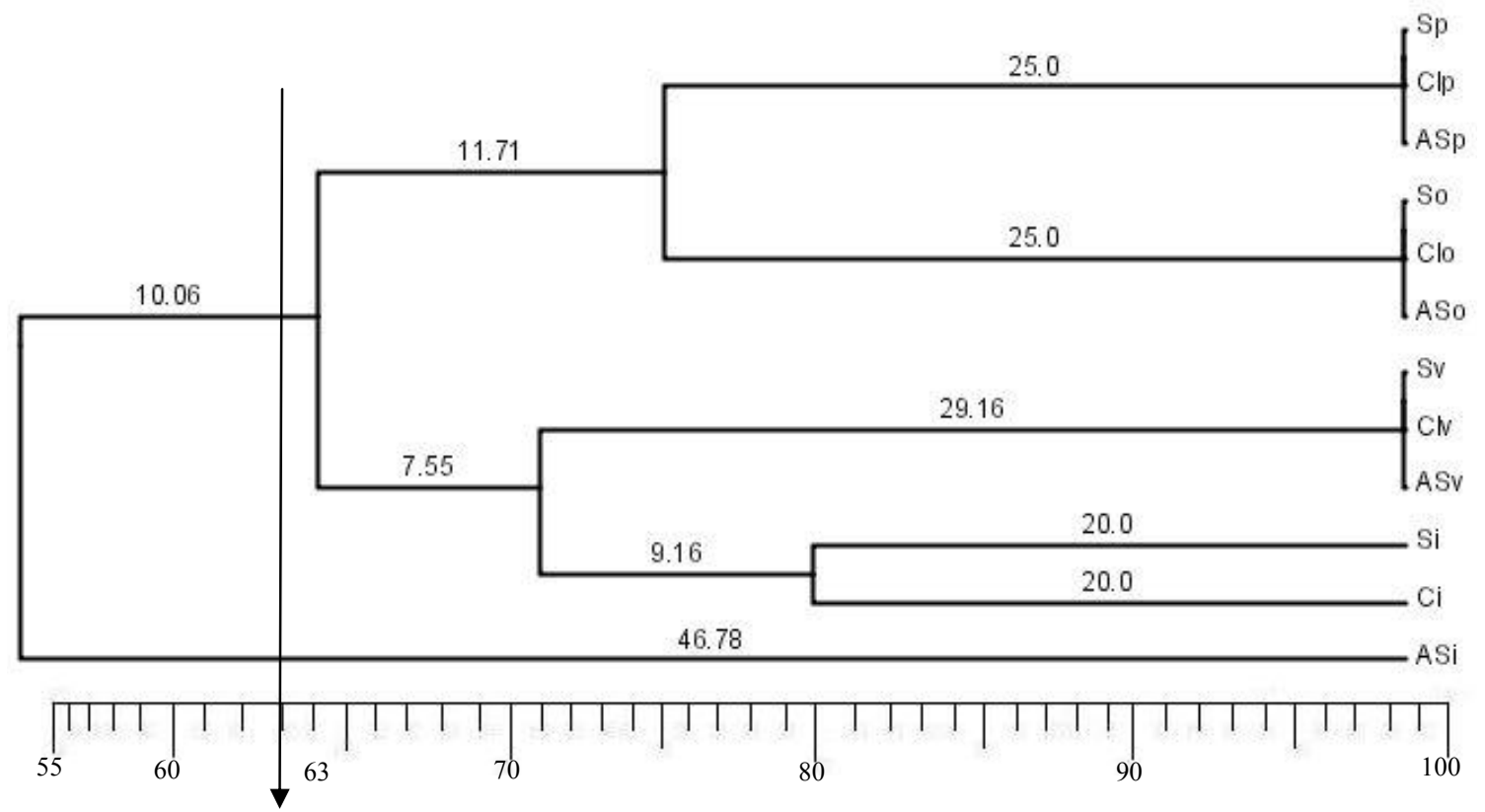

Figura 5.44: Dendrograma das variações sazonais na lagoa facultativa com primers $p u f \mathrm{M}$ referente ao horário T3 $(02: 00 \mathrm{~h})$.

$\mathrm{S}=$ sub-superfície, $\mathrm{CI}=$ camada intermediária, $\mathrm{AS}=$ interface água-sedimento. A régua indica porcentagens do coeficiente de similaridade

Os valores de $\mathrm{pH}$, temperatura e oxigênio dissolvido na sub-superfície, no verão, foram de 11,$3 ; 28,7^{\circ} \mathrm{C}$ e $3,2 \mathrm{mg} / \mathrm{L}$, respectivamente. Na camada intermediária, os valores foram de 9,$9 ; 26,7^{\circ} \mathrm{C}$ e $0,23 \mathrm{mg} / \mathrm{L}$, respectivamente. $\mathrm{Na}$ interface água-sedimento, os valores foram de 9,$7 ; 25,5^{\circ} \mathrm{C}$ e $0,08 \mathrm{mg} / \mathrm{L}$, respectivamente. No verão, foram obtidas 2 bandas no DGGE, nas diferentes profundidades e similaridade de $100 \%$.

Os valores de $\mathrm{pH}$, temperatura e oxigênio dissolvido na sub-superfície, no inverno, foram de 10,$2 ; 20,8^{\circ} \mathrm{C}$ e $6,6 \mathrm{mg} / \mathrm{L}$, respectivamente. $\mathrm{Na}$ camada intermediária, os valores foram de 10,$0 ; 19,8^{\circ} \mathrm{C}$ e $3,0 \mathrm{mg} / \mathrm{L}$, respectivamente. No inverno, com menores valores de temperatura na sub-superfície e camada intermediária, foram observadas 3 e 4 bandas, respectivamente, e similaridade de $80 \%$. No verão, para temperaturas maiores, esses valores foram de 2 e 2 bandas, respectivamente.

Os valores de $\mathrm{pH}$, temperatura e oxigênio dissolvido na interface água-sedimento, no inverno, foram de 9,$8 ; 19,6^{\circ} \mathrm{C}$ e $0,5 \mathrm{mg} / \mathrm{L}$, respectivamente. Esse ponto de coleta apresentou 2 bandas no DGGE realizado. 
As similaridades de $100 \%$ verificadas na primavera, verão e outono, para as três profundidades, indicaram que a coluna d'agua na lagoa facultativa encontrava-se aparentemente homogênea, favorecendo assim a manutenção das mesmas populações de bactérias fototróficas púrpuras nas diferentes profundidades.

Em relação aos valores da radiação solar fotossinteticamente ativa incidente na superfície da lagoa anaeróbia, às 14:00 h, foram similares na primavera $\left(545,8 \mu \mathrm{Em}^{-2} \mathrm{~s}^{-1}\right) \mathrm{e}$ no inverno $\left(574,8 \mu \mathrm{Em}^{-2} \mathrm{~s}^{-1}\right)$, e permitiram o crescimento de populações similares de bactérias fototróficas púrpuras, nas diferentes profundidades (Tabela 5.5). Também, os valores foram similares no verão e outono para o horário das 14:00 h (T1). A radiação solar fotossinteticamente ativa incidente, no outono, foi de $264,6 \mu \mathrm{Em}^{-2} \mathrm{~s}^{-1}$, a qual favoreceu maior diversidade de bactérias fototróficas púrpuras nessa época do ano. No verão foi registrada a menor radiação solar fotossinteticamente ativa incidente, no mesmo horário de coleta $\left(245,5 \mu \mathrm{Em}^{-2} \mathrm{~s}^{-1}\right)$, e menor número de populações de bactérias fototróficas púrpuras do que as verificadas no outono, mas superior às observadas na primavera e inverno.

Tabela 5.5: Radiação solar nas diferentes épocas do ano na superfície da lagoa anaeróbia

\begin{tabular}{|c|c|c|c|}
\hline \multirow[t]{2}{*}{ Estações do ano } & \multicolumn{3}{|c|}{$\begin{array}{c}\text { Radiação Solar Fotossinteticamente } \\
\text { Ativa } \\
\left(\mu E m^{-2} s^{-1}\right)\end{array}$} \\
\hline & T0 & T1 & T4 \\
\hline Primavera & & 545,8 & 100,0 \\
\hline Verão & 325,8 & 245,5 & 102,9 \\
\hline Outono & 76,6 & 264,6 & 46,7 \\
\hline Inverno & 225,4 & 574,8 & 58,8 \\
\hline
\end{tabular}

Horários: $(\mathrm{T} 0)=08: 00 \mathrm{~h} ;(\mathrm{T} 1)=14: 00 \mathrm{~h} ;(\mathrm{T} 4)=08: 00 \mathrm{~h}$

A radiação solar fotossinteticamente ativa incidente, na superfície da lagoa facultativa, às 14:00 $\mathrm{h}$, na primavera foi de $221,3 \mu \mathrm{Em}^{-2} \mathrm{~s}^{-1}$. Tal radiação permitiu o crescimento de populações similares de bactérias fototróficas púrpuras nas diferentes profundidades. No verão foi registrada a maior radiação solar fotossinteticamente ativa 
incidente, no mesmo horário de coleta $\left(1.344 \mu \mathrm{Em}^{-2} \mathrm{~s}^{-1}\right)$, e populações de bactérias fototróficas púrpuras similares às verificadas na primavera. A radiação solar fotossinteticamente ativa incidente, no outono, foi de $409,9 \mu \mathrm{Em}^{-2} \mathrm{~s}^{-1}$, a qual favoreceu a maior diversidade de bactérias fototróficas púrpuras nessa época do ano. No inverno, com valor de $519,8 \mu \mathrm{Em}^{-2} \mathrm{~s}^{-1}$, superior ao verificado no outono, a diversidade das bactérias fototróficas púrpuras foi ligeiramente inferior ao verificado no outono (Tabela 5.6). Embora os valores de radiação, no outono e no inverno tenham sido próximos, nessa última estação as lagoas não se encontravam em operação e, conseqüentemente, ocorreu alteração na diversidade de bactérias, em função da ação de outras características não relacionadas diretamente com a radiação solar fotossinteticamente ativa incidente.

Tabela 5.6: Radiação solar nas diferentes épocas do ano na superfície da lagoa facultativa

\begin{tabular}{|c|c|c|c|}
\hline \multirow[t]{2}{*}{ Estações do ano } & \multicolumn{3}{|c|}{$\begin{array}{c}\text { Radiação Solar Fotossinteticamente } \\
\text { Ativa } \\
\left(\mu \mathrm{Em}^{-2} \mathrm{~s}^{-1}\right)\end{array}$} \\
\hline & T0 & T1 & T4 \\
\hline Primavera & 342 & 221,3 & 52,7 \\
\hline Verão & 391,7 & 1344 & 77,7 \\
\hline Outono & 479,2 & 409,9 & 1034 \\
\hline Inverno & 154,8 & 519,8 & 312,5 \\
\hline
\end{tabular}

Horários: $(\mathrm{T} 0)=08: 00 \mathrm{~h} ;(\mathrm{T} 1)=14: 00 \mathrm{~h} ;(\mathrm{T} 4)=08: 00 \mathrm{~h}$

Segundo Kellner (1996), a principal fonte de energia térmica introduzida nas lagoas de estabilização é a radiação solar. A energia solar é constituída por ondas eletromagnéticas que se propagam à velocidade da luz $(300.000 \mathrm{Km} / \mathrm{s})$, com comprimentos de onda entre $100 \mathrm{~nm}$ e $100.000 \mathrm{~nm}$.

Os comprimentos de onda de maior interesse ecológico abrangem as faixas do ultravioleta, do visível e do infravermelho. A faixa do visível, que compreende de $400 \mathrm{~nm}$ (luz azul) a $740 \mathrm{~nm}$ (luz vermelha), assume maior importância dado a sua participação no processo fotossintético (ESTEVES, 1988). Por ser aproximadamente a faixa do espectro sensível ao olho humano é denominada de luz, e em ecologia vegetal é denominada de 
radiação fotossinteticamente ativa (RFA), por ser esta a fração da radiação total que é absorvida pelas clorofilas.

Bactérias fotótroficas anoxigênicas púrpuras absorvem energia na região do espectro que corresponde à da luz complementar às que são utilizadas pelas plantas e algas, principalmente nos comprimentos de onda de $500 \mathrm{~nm}$, por meio dos carotenóides, e de 800 $\mathrm{nm}$ por meio das bacterioclorofilas (HU et al., 1998). As bactérias fototróficas verdes utilizam luz na faixa de $460 \mathrm{~nm}$ a $750 \mathrm{~nm}$.

\subsubsection{Diversidade das bactérias redutoras de sulfato}

A partir do DGGE realizado com primers para as bactérias redutoras de sulfato, de amostra da lagoa facultativa coletada às 14:00 h (T1), foi elaborado o dendrograma da Figura 5.45. Corte arbitrário de $67 \%$ de similaridade foi realizado, sendo observados três agrupamentos principais. O primeiro agrupamento relacionou a distribuição dos microrganismos na sub-superfície e camada intermediária, no verão, com $66 \%$ de similaridade, com $60 \%$ de similaridade entre aquelas e a distribuição encontrada na interface água-sedimento, no inverno. O segundo agrupamento indicou que a distribuição dos microrganismos na interface água-sedimento, no verão, relacionou-se com $59 \%$ de similaridade, com o terceiro agrupamento do dendrograma. O terceiro agrupamento indicou $100 \%$ de similaridade existente entre a sub-superfície e a camada intermediária, no outono, e $80 \%$ de similaridade com a interface água-sedimento, na mesma época. As distribuições na sub-superfície e camada intermediária, no inverno, foram similares em 85\%.

Os valores de $\mathrm{pH}$, temperatura e oxigênio dissolvido na sub-superfície, no verão, foram de 12,$0 ; 32,1^{\circ} \mathrm{C}$ e $9,5 \mathrm{mg} / \mathrm{L}$, respectivamente. $\mathrm{Na}$ camada intermediária, os valores foram de 9,$5 ; 26,1^{\circ} \mathrm{C}$ e $0,02 \mathrm{mg} / \mathrm{L}$, respectivamente. $\mathrm{Na}$ interface água-sedimento, no inverno, os valores foram de 10,$0 ; 19,6^{\circ} \mathrm{C}$ e $2,9 \mathrm{mg} / \mathrm{L}$, respectivamente. Foram verificadas as menores diversidades de bactérias redutoras de sulfato nessas épocas do ano (4 e 2 bandas na sub-superfície e camada intermediária no verão; e 5 bandas na interface águasedimento, no inverno) e similaridades variando de $64 \%$ a $60 \%$, respectivamente. 


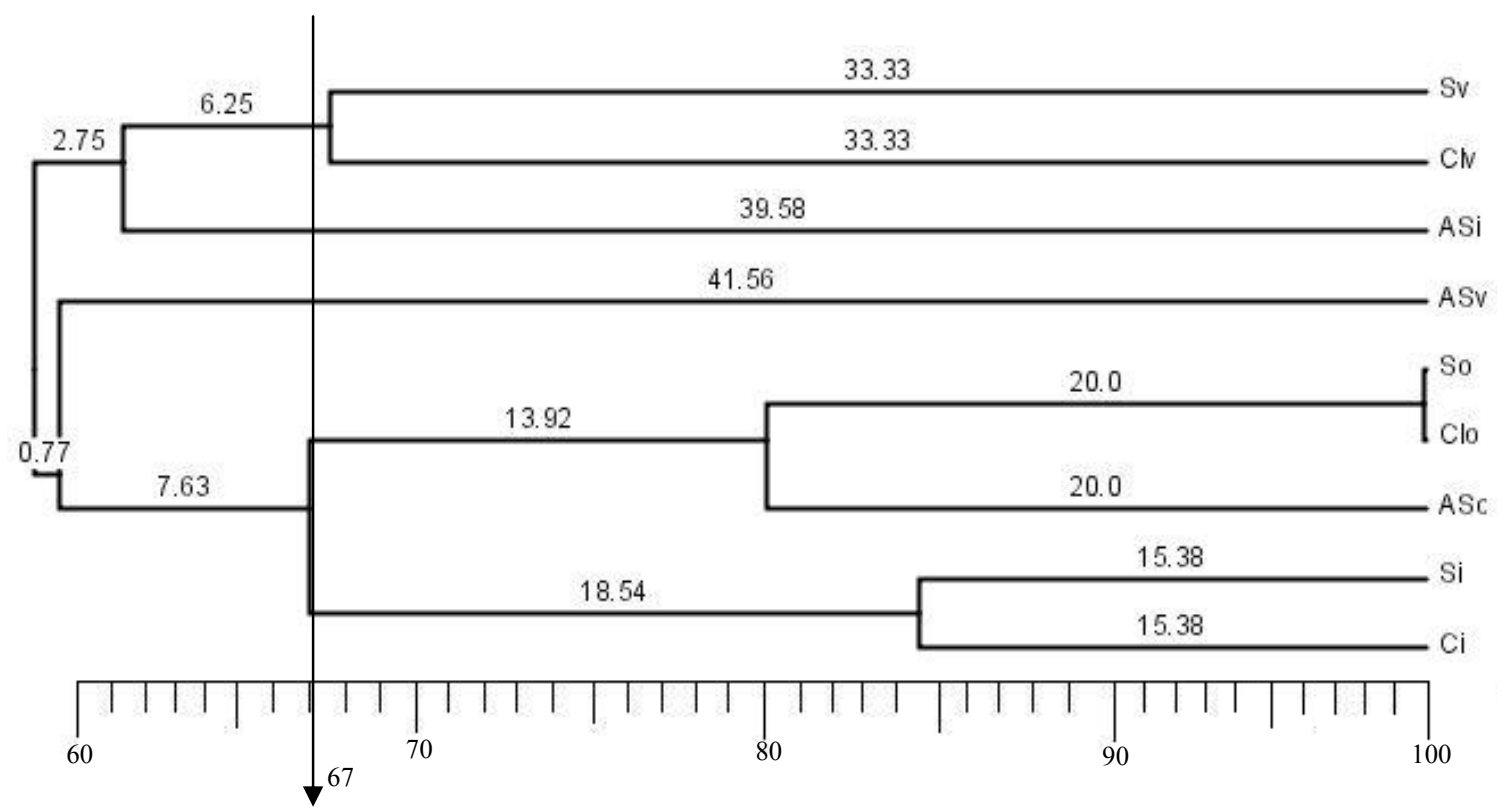

Figura 5.45: Dendrograma das variações sazonais na lagoa facultativa com primers para as BRS referente ao horário $\mathrm{T} 1(14: 00 \mathrm{~h})$.

$\mathrm{S}=$ sub-superfície, $\mathrm{CI}=$ camada intermediária, $\mathrm{AS}=$ interface água-sedimento. A régua indica porcentagens do coeficiente de similaridade

Os valores de $\mathrm{pH}$, temperatura e oxigênio dissolvido na interface água-sedimento, no verão, foram de 10,$0 ; 25,4^{\circ} \mathrm{C}$ e $0,1 \mathrm{mg} / \mathrm{L}$, respectivamente. Tais condições físicoquímicas permitiram a formação de um único agrupamento no dendrograma e presença de 3 bandas no DGGE, com similaridade de 59\%.

Os valores de $\mathrm{pH}$, temperatura e oxigênio dissolvido na sub-superfície, no outono, foram de 10,$0 ; 34,3^{\circ} \mathrm{C}$ e $7,2 \mathrm{mg} / \mathrm{L}$, respectivamente. $\mathrm{Na}$ camada intermediária, os valores foram de 9,$3 ; 27,5^{\circ} \mathrm{C}$ e $1,1 \mathrm{mg} / \mathrm{L}$, respectivamente. Observou-se uma maior diversidade nessa época nas duas profundidades (12 e 12 bandas, respectivamente), superior à verificada na lagoa anaeróbia, no mesmo período. Os menores valores verificados na interface água-sedimento, na mesma época, 8,$2 ; 26,5^{\circ} \mathrm{C}$ e $0,1 \mathrm{mg} / \mathrm{L}$, respectivamente, possivelmente foram desfavoráveis, pois uma menor diversidade foi verificada nesse ponto de coleta ( 9 bandas). As similaridades verificadas foram de $100 \%$ e $80 \%$, respectivamente.

Os valores de $\mathrm{pH}$, temperatura e oxigênio dissolvido na sub-superfície, no inverno, foram de 10,$3 ; 20,1^{\circ} \mathrm{C}$ e $5,6 \mathrm{mg} / \mathrm{L}$, respectivamente. $\mathrm{Na}$ camada intermediária, os valores foram de 10,$1 ; 19,8^{\circ} \mathrm{C}$ e $4,4 \mathrm{mg} / \mathrm{L}$, respectivamente. Foram observadas menores 
diversidades de BRS nessa época do ano, em relação ao outono (12 e 12 bandas, respectivamente), mas superiores às verificadas no verão (4 e 2 bandas, respectivamente).

A partir do DGGE realizado com primers para as BRS, de amostra da lagoa facultativa coletada às 02:00 h (T3), foi elaborado o dendrograma da Figura 5.46. Corte arbitrário de $65 \%$ de similaridade foi realizado, sendo observados três agrupamentos principais. O primeiro agrupamento relacionou com $60 \%$ de similaridade, a distribuição dos microrganismos na sub-superfície, no verão, com as verificadas na camada intermediária e na interface água-sedimento, no inverno. O segundo agrupamento relacionou com $67 \%$ de similaridade, a distribuição dos microrganismos na camada intermediária, no verão, com a da interface água-sedimento, no inverno. No terceiro agrupamento foi observada similaridade de 100\%, para as distribuições encontradas na camada intermediária e interface água-sedimento, no outono. Ambos os pontos de coleta relacionaram-se com $90 \%$ de similaridade com a sub-superfície, nesta mesma estação do ano.

Os valores de $\mathrm{pH}$, temperatura e oxigênio dissolvido na sub-superfície, no verão, foram de 11,$3 ; 28,7^{\circ} \mathrm{C}$ e $3,2 \mathrm{mg} / \mathrm{L}$, respectivamente. Os valores de $\mathrm{pH}$, temperatura e oxigênio dissolvido, na camada intermediária, no verão, foram de 9,$9 ; 26,7^{\circ} \mathrm{C}$ e $0,23 \mathrm{mg} / \mathrm{L}$, respectivamente. Os valores de $\mathrm{pH}$, temperatura e oxigênio dissolvido, na interface águasedimento, no verão, foram de 9,$7 ; 25,5^{\circ} \mathrm{C}$ e $0,08 \mathrm{mg} / \mathrm{L}$, respectivamente. $\mathrm{O}$ número de bandas verificadas na sub-superfície, camada intermediária e interface água-sedimento nessa época do ano foram de 3,1 e 3 bandas, respectivamente.

$\mathrm{Na}$ sub-superfície, no inverno, os valores foram de 10,$2 ; 20,8^{\circ} \mathrm{C}$ e $6,6 \mathrm{mg} / \mathrm{L}$, respectivamente. Na camada intermediária, os valores foram de 10,$0 ; 19,8^{\circ} \mathrm{C}$ e $3,0 \mathrm{mg} / \mathrm{L}$, respectivamente. $\mathrm{Na}$ interface água-sedimento, estes foram de 9,$8 ; 19,6^{\circ} \mathrm{C}$ e $0,5 \mathrm{mg} / \mathrm{L}$, respectivamente. O número de bandas verificado nessas profundidades, no inverno, foram de 2, 6 e 8 bandas, respectivamente.

As bandas obtidas na sub-superfície, no verão (similaridade de 60\%), também foram verificadas no inverno, com similaridade de $70 \%$. 


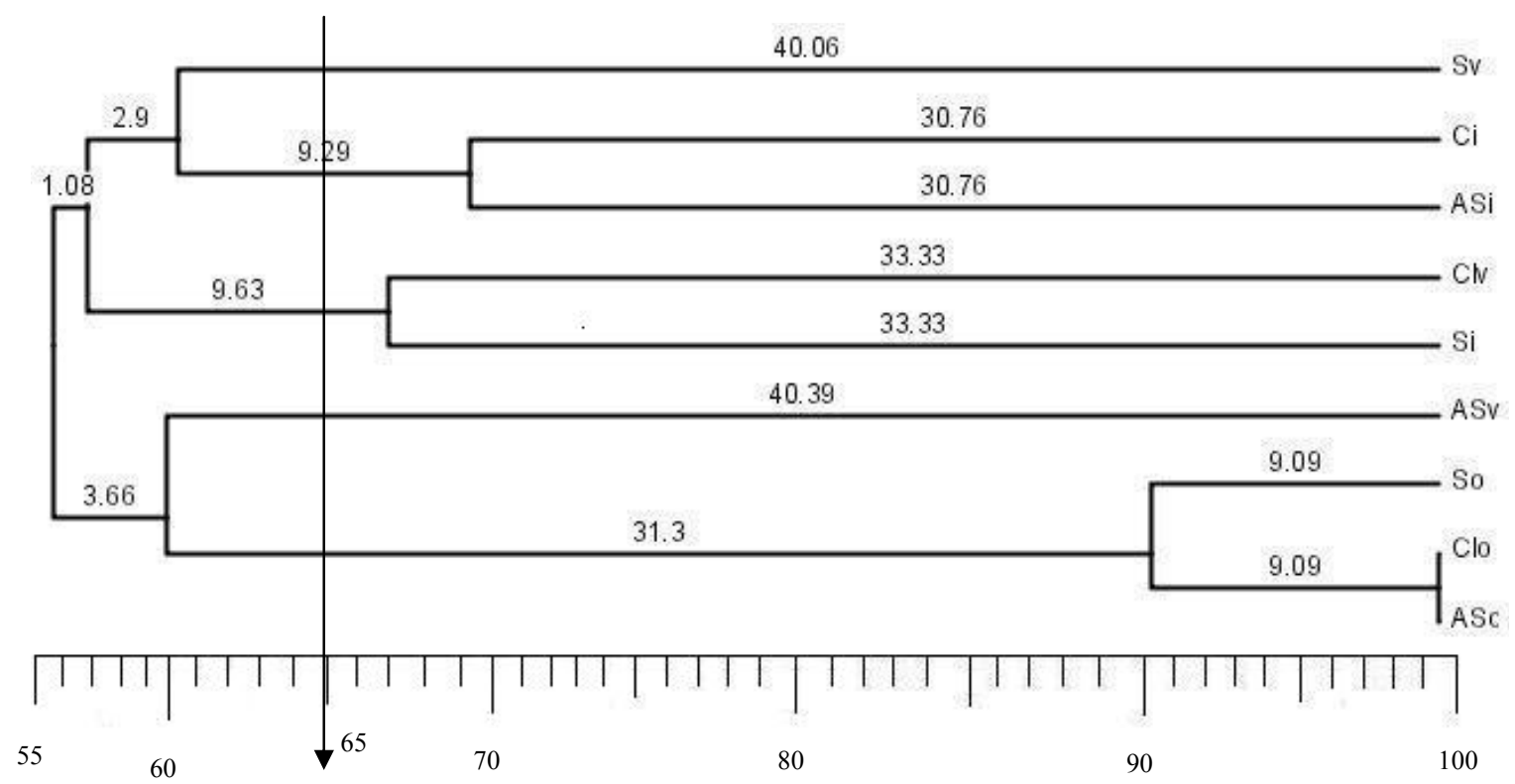

Figura 5.46: Dendrograma das variações sazonais na lagoa facultativa com primers para as BRS referente ao horário $\mathrm{T} 3(02: 00 \mathrm{~h})$

$\mathrm{S}=$ sub-superfície, $\mathrm{CI}=$ camada intermediária, $\mathrm{AS}=$ interface água-sedimento. A régua indica porcentagens do coeficiente de similaridade

Os valores de $\mathrm{pH}$, temperatura e oxigênio dissolvido na sub-superfície, no outono, foram de 8,$3 ; 30,6^{\circ} \mathrm{C}$ e $2,3 \mathrm{mg} / \mathrm{L}$, respectivamente. Na camada intermediária, os valores foram de 8,$1 ; 28,6^{\circ} \mathrm{C}$ e $0,07 \mathrm{mg} / \mathrm{L}$, respectivamente. Na interface água-sedimento, estes foram de 7,$4 ; 27,8^{\circ} \mathrm{C}$ e $0,3 \mathrm{mg} / \mathrm{L}$, respectivamente. Foram verificadas, nessa época e nestas profundidades, maiores diversidades de BRS, com 10, 9 e 9 bandas, respectivamente. 


\subsubsection{Análise Geral dos Parâmetros Físico-químicos}

As Tabelas 5.7 e 5.8 mostram os parâmetros físico-químicos do afluente e efluente da lagoa facultativa. A Tabela 5.9 mostra as porcentagens de remoção verificadas na lagoa facultativa. Maior remoção de sulfato foi verificada no outono $(100 \%)$, no horário T3 (temperatura afluente de $27,8^{\circ} \mathrm{C}$ e efluente de $28,6^{\circ} \mathrm{C}$ ). A maior remoção de matéria orgânica $\left(\mathrm{DQO}_{\mathrm{b}}\right)$ também foi verificada no outono, no horário $\mathrm{T} 3$, com 25,6\%. Uma remoção de $62,4 \%$ de sólidos suspensos voláteis foi verificada na primavera, no horário T1, com temperatura afluente de $22,9^{\circ} \mathrm{C}$ e efluente, de $24,3^{\circ} \mathrm{C}$. A remoção de $60,2 \%$ de NTK foi obtida no outono, no horário $\mathrm{T} 1$ (temperatura afluente de $27,2^{\circ} \mathrm{C}$, e efluente de $32,4^{\circ} \mathrm{C}$ ). Remoção de $58,8 \%$ de fósforo total foi verificada no outono, no horário T3 e a maior remoção de nitrato foi observada na primavera, com 14,6\%, no horário T1. A remoção de $73,0 \%$ de nitrogênio amoniacal foi verificada no outono, em T3, enquanto para o fósforo total dissolvido a maior remoção foi observada na primavera, em T1. Remoção de 95,8\% de ortofosfato foi verificada na primavera, em T3.

Aplicando a análise de variância, foram verificadas diferenças significativas na remoção de nitrogênio amoniacal, nitrito e nitrato, nas coletas realizadas nas diferentes épocas do ano $(\mathrm{p}=0,010)$ (Tabelas Anexo C11 e Anexo C12).

A análise de variância indicou que não foram verificadas diferenças significativas na remoção de nitrogênio amoniacal, nitrito e nitrato, na primavera e inverno (período de seca), e nem no outono e verão (período de chuva), sendo o valor de $\mathrm{p}=0,240$ (Tabelas Anexo C13 e Anexo C14).

Finalmente, a análise de variância indicou que não foram verificadas diferenças significativas entre as lagoas anaeróbia e facultativa, com respeito à remoção de nitrogênio amoniacal, nitrito e nitrato, nos dois horários de coleta, e nas diferentes profundidades consideradas e épocas do ano $(\mathrm{p}=0,548)$ (Tabelas Anexo C31 e Anexo C32). 
Tabela 5.7: Valores dos parâmetros físico-químicos verificados no afluente e efluente da lagoa facultativa referente ao horário $\mathrm{T} 1(14: 00 \mathrm{~h})$

\begin{tabular}{l|cccccc}
\hline \multicolumn{1}{c|}{ Parâmetros } & \multicolumn{7}{c}{ AFLUENTE } & \multicolumn{3}{c}{ EFLUENTE } \\
& Primavera & Verão & Outono & Primavera & Verão & Outono \\
& & & & & & \\
& 20 & 11 & 0,0 & 4 & 12 & 1,0 \\
Sulfato $(\mathrm{mg} / \mathrm{L})$ & 122 & 148 & 174,3 & 125 & 160 & 173,7 \\
$\mathrm{DQO}_{\mathrm{b}}(\mathrm{mg} / \mathrm{L})$ & 213 & 93 & 0,0 & 80 & 117 & 47 \\
$\mathrm{SSV}(\mathrm{mg} / \mathrm{L})$ & 28,75 & 26,23 & 19,69 & 30,43 & 13,25 & 7,84 \\
NTK $(\mathrm{mg} / \mathrm{L})$ & 3,84 & 0,86 & 3,36 & 12,33 & 1,59 & 2,75 \\
PT $(\mathrm{mg} / \mathrm{L})$ & 1,85 & 1,66 & 2,59 & 1,58 & 1,95 & 2,3 \\
Nitrato $(\mathrm{mg} / \mathrm{L})$ & 3,66 & 6,0 & 4,48 & 18,68 & 13,58 & 6,29 \\
Nitrito $(\mu \mathrm{g} / \mathrm{L})$ & 18,96 & 11,59 & 15,4 & 9,16 & 4,23 & 2,83 \\
Nitrogênio & & & & & & \\
amoniacal $(\mathrm{mg} / \mathrm{L})$ & 2,91 & 0,99 & 0,002 & 0,31 & 0,72 & 0,001 \\
PTD $(\mathrm{mg} / \mathrm{L})$ & 1009,5 & 984,25 & 2,12 & 44,81 & 273,64 & 1,13 \\
Ortofosfato $(\mu \mathrm{g} / \mathrm{L})$ & \multicolumn{7}{c}{} & & & & & \\
\hline
\end{tabular}

Tabela 5.8: Valores dos parâmetros físico-químicos verificados no afluente e efluente da lagoa facultativa referente ao horário $\mathrm{T} 3(02: 00 \mathrm{~h})$

\begin{tabular}{l|cccccc}
\hline \multicolumn{1}{c|}{ Parâmetros } & \multicolumn{7}{c}{ AFLUENTE } & \multicolumn{3}{c}{ EFLUENTE } \\
& Primavera & Verão & Outono & Primavera & Verão & Outono \\
& & & & & & \\
& 11 & 16 & 1,0 & 17 & 10 & 0,0 \\
Sulfato $(\mathrm{mg} / \mathrm{L})$ & 87 & 106 & 134,7 & 119 & 160 & 100,2 \\
$\mathrm{DQO}(\mathrm{mg} / \mathrm{L})$ & 6 & 70 & 90 & 223 & 53 & 77 \\
$\mathrm{SSV}(\mathrm{mg} / \mathrm{L})$ & 28 & 10,73 & 16,15 & 23,33 & 8,49 & 7,56 \\
$\mathrm{NTK}(\mathrm{mg} / \mathrm{L})$ & 1,49 & 1,64 & 4,15 & 4,09 & 2,16 & 1,71 \\
$\mathrm{PT}(\mathrm{mg} / \mathrm{L})$ & 1,25 & 0,6 & 2,48 & 1,39 & 1,79 & 2,24 \\
Nitrato $(\mathrm{mg} / \mathrm{L})$ & 3,6 & 4,78 & 3,31 & 14,35 & 21,61 & 18,71 \\
Nitrito $(\mu \mathrm{g} / \mathrm{L})$ & 20,36 & 8,96 & 14,11 & 9,21 & 4,76 & 3,81 \\
Nitrogênio & & & & & & \\
amoniacal $(\mathrm{mg} / \mathrm{L})$ & 0,63 & 0,88 & 0,002 & 0,188 & 1,0 & 0,001 \\
PTD $(\mathrm{mg} / \mathrm{L})$ & 513,6 & 766,5 & 1,74 & 39,98 & 843,75 & 0,76 \\
Ortofosfato $(\mu \mathrm{g} / \mathrm{L})$ & & & & & & \\
\hline
\end{tabular}


Tabela 5.9: Eficiências de redução (\%) dos parâmetros físico-químicos verificados na lagoa facultativa

\begin{tabular}{|c|c|c|c|c|c|c|}
\hline \multirow{2}{*}{ Parâmetros } & \multicolumn{3}{|c|}{ \% Remoção (T1) } & \multicolumn{3}{|c|}{ \% Remoção (T3) } \\
\hline & Primavera & Verão & Outono & Primavera & Verão & Outono \\
\hline Sulfato $(\mathrm{mg} / \mathrm{L})$ & 80 & $*$ & $*$ & * & 37,5 & 100 \\
\hline $\mathrm{DQO}_{\mathrm{b}}(\mathrm{mg} / \mathrm{L})$ & $*$ & * & 0,3 & * & $*$ & 25,6 \\
\hline $\mathrm{SSV}(\mathrm{mg} / \mathrm{L})$ & 62,4 & * & $*$ & $*$ & 24,3 & 14,4 \\
\hline NTK $(\mathrm{mg} / \mathrm{L})$ & $*$ & 49,5 & 60,2 & 16,7 & 20,9 & 53,2 \\
\hline PT (mg/L) & $*$ & $*$ & 18,2 & $*$ & $*$ & 58,8 \\
\hline Nitrato $(\mathrm{mg} / \mathrm{L})$ & 14,6 & * & 11,2 & 6,6 & * & 9,7 \\
\hline Nitrito $(\mu \mathrm{g} / \mathrm{L})$ & $*$ & * & $*$ & $*$ & * & $*$ \\
\hline $\begin{array}{l}\text { Nitrogênio } \\
\text { amoniacal (mg/L) }\end{array}$ & 51,7 & 63,5 & 81,6 & $*$ & 46,9 & 73,0 \\
\hline PTD $(\mathrm{mg} / \mathrm{L})$ & 89,3 & 27,0 & 36,6 & 26,5 & $*$ & 42,7 \\
\hline Ortofosfato $(\mathrm{mg} / \mathrm{L})$ & 95,6 & 72,2 & 46,7 & 95,8 & * & 56,3 \\
\hline
\end{tabular}

*houve aumento dessa variável no efluente final

Falco (2005) obteve, no verão, no efluente final, quando a temperatura do afluente foi de $30,6^{\circ} \mathrm{C}$ e do efluente final, $30,0^{\circ} \mathrm{C}$, uma maior redução de sólidos suspensos, matéria orgânica e das principais formas nitrogenadas (nitrogênio total, amoniacal e orgânico). Em agosto, quando as temperaturas foram mais baixas $\left(26,9^{\circ} \mathrm{C}\right.$, no afluente; e $23,0^{\circ} \mathrm{C}$, no efluente), a autora obteve as menores porcentagens de redução dessas variáveis.

Nesta pesquisa, o maior número de populações de microrganismos foi verificado no período diurno (14:00 h), nas diferentes épocas do ano, sugerindo uma maior presença dos microrganismos nesse período. Em relação à coleta realizada às 02:00 h (T3), verificou-se diminuição no número de populações no inverno e manutenção no verão e outono, em relação à coleta das 14:00 $\mathrm{h}$.

Em relação aos ácidos orgânicos voláteis determinados nas lagoas anaeróbia e facultativa, na primavera, as concentrações foram reduzidas ou abaixo do limite de detecção. Na lagoa anaeróbia, em amostras das 08:00 h (T0), foi determinado na camada intermediária, 4,2 mg/L de ácido acético. Na coleta realizada às 20:00 h (T2), foram determinados no afluente, $26,9 \mathrm{mg} / \mathrm{L}$ de ácido acético, $2,79 \mathrm{mg} / \mathrm{L}$ de ácido propiônico, 0,12 $\mathrm{mg} / \mathrm{L}$ de ácido butírico, $0,2 \mathrm{~m} / \mathrm{L}$ de ácido isovalérico e $0,7 \mathrm{mg} / \mathrm{L}$ de ácido valérico. Às 08:00 h (T4) foram determinados, no afluente, $22,8 \mathrm{mg} / \mathrm{L}$ de ácido acético, 5,7 mg/L de 
ácido propiônico, $1,0 \mathrm{mg} / \mathrm{L}$ de ácido butírico, $0,5 \mathrm{mg} / \mathrm{L}$ de ácido isovalérico, e $0,8 \mathrm{mg} / \mathrm{L} \mathrm{de}$ ácido valérico (Tabelas B3 e B6).

$\mathrm{Na}$ lagoa facultativa, as 08:00 h (T0), foram determinados na sub-superfície, camada intermediária, interface água-sedimento e efluente, apenas traços de ácido isovalérico. Às 20:00 h (T2), foram determinados na interface água-sedimento, $35 \mathrm{mg} / \mathrm{L} \mathrm{de}$ ácido acético e 1,2 mg/L de ácido isovalérico. Às 08:00 h (T4), na sub-superfície, foram determinados $7,8 \mathrm{mg} / \mathrm{L}$ de ácido acético, traços de ácido isovalérico e ácido valérico, e 1,2 $\mathrm{mg} / \mathrm{L}$ de ácido caproico.

No verão, foi obtido na lagoa anaeróbia, nos diferentes horários de coletas, principalmente ácido acético, variando de $8,7 \mathrm{mg} / \mathrm{L}$ na camada intermediária (T4: 08:00 h) a 33,5 mg/L, no afluente (T1: 14:00 h). Na lagoa facultativa, foi obtido somente ácido acético no período das 02:00 h (T3), em concentrações de 8,1 mg/L e 8,4 mg/L, no efluente e na interface água-sedimento, respectivamente (Tabelas B9 e B12).

No outono, na lagoa anaeróbia, houve predominância de ácido acético, variando de 3,8 mg/L na sub-superfície (T4: 08:00 h) a 49,5 mg/L no afluente (T2: 20:00 h). Também na lagoa facultativa, foi determinado somente ácido acético, variando de $8,9 \mathrm{mg} / \mathrm{L}$ a 15,1 mg/L no afluente (Tabelas B15 e B18). No inverno, foi obtido somente ácido acético nas lagoas anaeróbia e facultativa, variando de $3,31 \mathrm{mg} / \mathrm{L}$ (T4: 08:00 h) a 5,18 mg/L (T2: 20:00 h) (Tabelas B21 e B24).

Foi verificada, no outono, uma maior diversidade do Domínio Bacteria, bactérias fototróficas púrpuras e bactérias redutoras de sulfato. Na primavera foram verificadas menores diversidades desses microrganismos estudados.

Tanto na lagoa anaeróbia, como na lagoa facultativa foi observado um total de 5 populações de microrganismos pertencentes ao Domínio Bacteria, comum aos diferentes pontos de amostragem, considerando os dois horários de coletas (14:00 h e 02:00 h). Na lagoa facultativa, foi observada maior diversidade do Domínio Bacteria do que na lagoa anaeróbia, assim como das BRS.

Verificou-se maior diversidade de bactérias fototróficas púrpuras na lagoa anaeróbia do que na lagoa facultativa, com duas populações predominantes durante as quatro estações do ano e nas diferentes profundidades. Na lagoa facultativa foram verificadas populações comuns, nas diferentes épocas do ano e nas diferentes profundidades. 
As bactérias fototróficas anoxigênicas são bactérias Gram negativas, unicelulares ou podem formar filamentos multicelulares. São predominantemente bactérias aquáticas, que crescem em condições anaeróbias, realizando fotossíntese sem produção de oxigênio. Apresentam bacterioclorofilas (a, b, c, d, e, e g), e carotenóides (grupos 1-5) que absorvem ampla faixa de comprimentos de onda, entre $375 \mathrm{~nm}$ a $1.030 \mathrm{~nm}$. Todas as espécies são potencialmente mixotróficas e fotoassimilam compostos orgânicos simples, tais como acetato e piruvato; apresentando, também, crescimento quimiolitoautotrófico e quimioorganotrófico (PFENNIG e TRUPER, 1989).

As bactérias fototróficas anoxigênicas púrpuras sulfurosas, em condições anaeróbias, apresentam crescimento fotolitoautotrófico, com sulfeto ou enxofre elementar como doador de elétrons, e utilizam amônia como fonte de nitrogênio. As bactérias fototróficas púrpuras não sulfurosas assimilam sulfato como fonte de enxofre, e utilizam amônia e muitos compostos orgânicos nitrogenados como fonte de nitrogênio (PFENNIG e TRUPER, 1989).

As faixas de $\mathrm{pH}$ e temperatura que favorecem o crescimento das bactérias fototróficas anoxigênicas, variam de 6,5 a 7,6 , e de $20^{\circ} \mathrm{C}$ a $40^{\circ} \mathrm{C}$ (ótimo de $30-35^{\circ} \mathrm{C}$ ), respectivamente (PFENNIG e TRUPER, 1989). Nas lagoas de estabilização, quase em todas as épocas do ano, exceto no outono, o $\mathrm{pH}$ foi superior a 8,0 , possivelmente devido à alta atividade fotossintética realizada pelas algas. No outono, o menor $\mathrm{pH}$ verificado nas duas lagoas favoreceu o desenvolvimento das bactérias fototróficas púrpuras. As maiores temperaturas verificadas no outono e verão coincidiram com as temperaturas ótimas de crescimento das bactérias fototróficas púrpuras, fato verificado no perfil de bandas padrões de DGGE. Como alguns desses microrganismos são sensíveis à presença de oxigênio dissolvido, maior diversidade foi verifica na lagoa anaeróbia em relação à lagoa facultativa. 


\subsection{Variações nictemerais}

\subsubsection{Lagoa anaeróbia}

Na Figura 5.47 são mostrados os perfis das bandas padrões do DGGE com primers para o Domínio Bacteria, onde foi verificada ligeira heterogeneidade vertical na primavera, com 6 bandas na camada intermediária, 5 bandas na interface água-sedimento, no horário de coleta das 14:00 h (T1); e 5 bandas na sub-superfície e camada intermediária, e 3 bandas na interface água-sedimento, no horário de coleta das 02:00 h (T3). Esses valores indicaram distribuição quase uniforme dos microrganismos na coluna da água.

No verão foi verificada heterogeneidade vertical no horário T3, com 4 bandas na sub-superfície e 9 bandas na camada intermediária e interface água-sedimento.

No outono foi verificada relativa manutenção das populações na sub-superfície e interface água-sedimento (com 9 e 12 bandas, respectivamente), em ambos horários de coleta. Na camada intermediária foram constatadas 8 e 10 bandas nos horários T1 e T3, respectivamente.

No inverno foi verificada heterogeneidade vertical em ambos os horários de coleta. Em T1 foram observadas 8 bandas na sub-superfície, e 5 bandas na camada intermediária e interface água-sedimento. Em T3 foram verificadas 9 bandas na sub-superfície e camada intermediária, e 4 bandas na interface água-sedimento. 


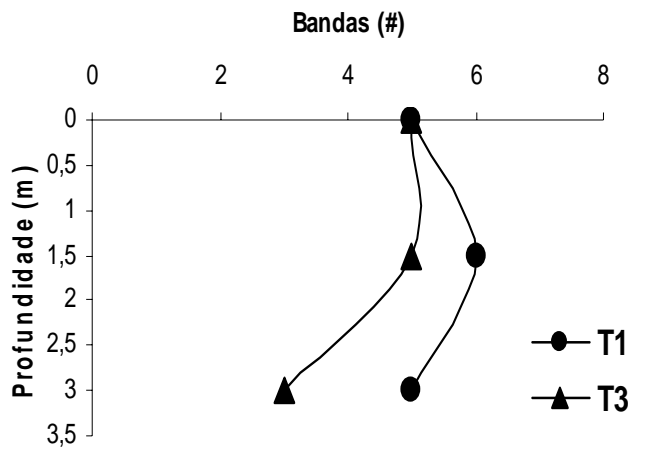

(a)

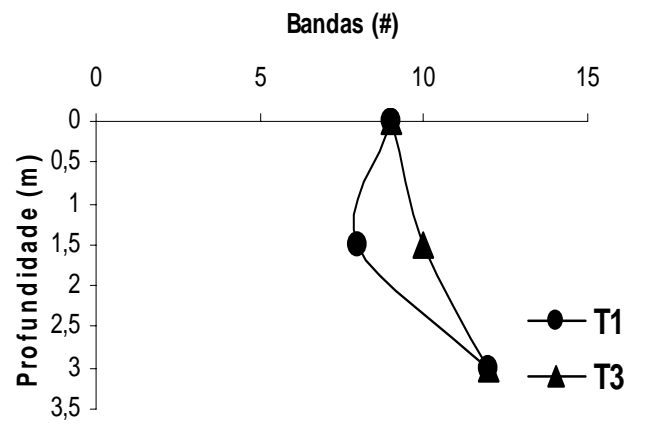

(c)

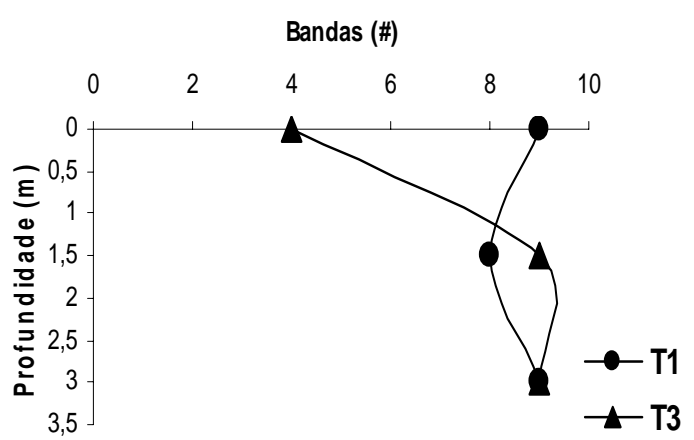

(b)

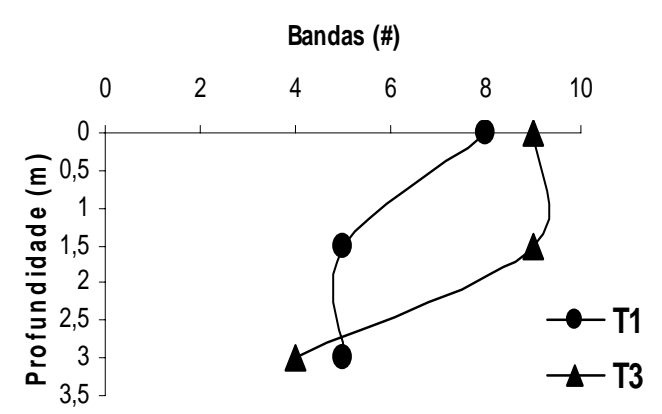

(d)

Figura 5.47: Perfis das bandas padrões do DGGE com primers para o Domínio Bacteria na lagoa anaeróbia (a: primavera, b:verão, c:outono, d:inverno)

A Figura 5.48 mostra os perfis das bandas padrões do DGGE com primers pufM. $\mathrm{Na}$ primavera foi verificada heterogeneidade vertical em T1, com 4 bandas na subsuperfície e camada intermediária, e 8 bandas na interface água-sedimento. Em T3 mantiveram-se constantes as populações de bactérias fototróficas na coluna da água, com 2 bandas em todos os pontos de amostragem. No verão foi verificada heterogeneidade vertical em ambos os horários de amostragem. Em T1 e T3 foram verificadas na subsuperfície 6 bandas. As populações mantiveram-se constantes na camada intermediária e interface água-sedimento, com 10 bandas em T1, e 3 bandas em T3, respectivamente.

No outono foi verificada heterogeneidade vertical em T1, com 14 bandas na subsuperfície, e 18 bandas na interface água-sedimento. No horário T3 foram observadas 8 bandas na sub-superfície, e 3 bandas na interface água-sedimento. No inverno foi verificado em T1, que as populações de bactérias fototróficas mantiveram-se constantes na coluna da 
água, com 7 bandas. No horário T3 foram observadas 6 bandas na sub-superfície e interface água-sedimento, e 4 bandas na camada intermediária.

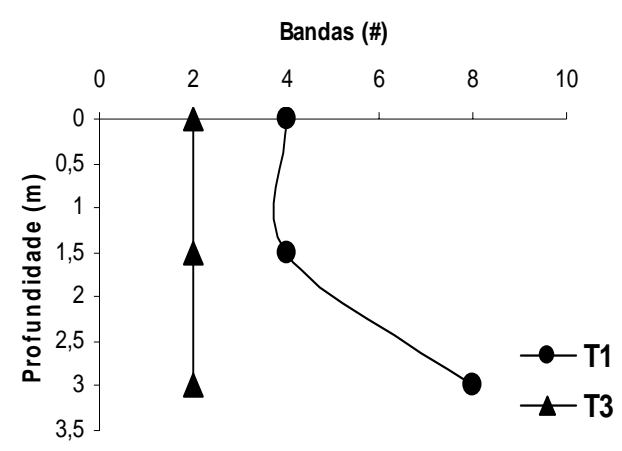

(a)

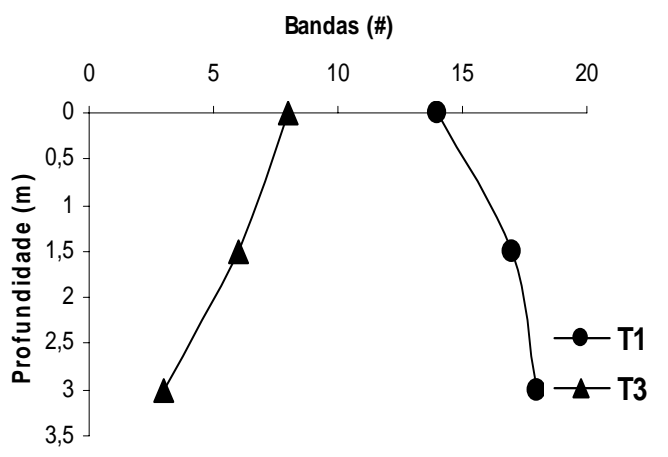

(c)

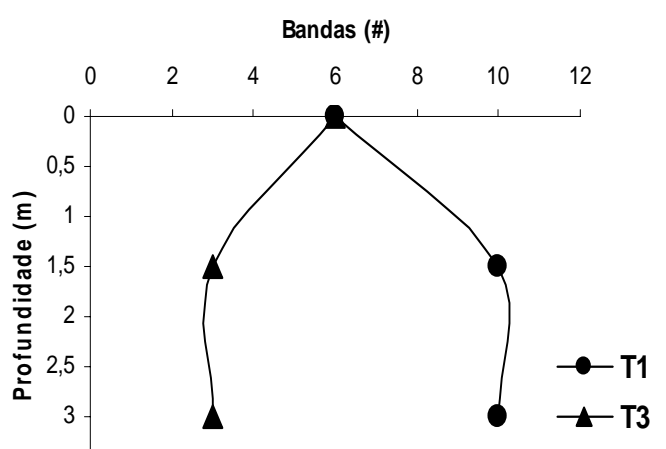

(b)

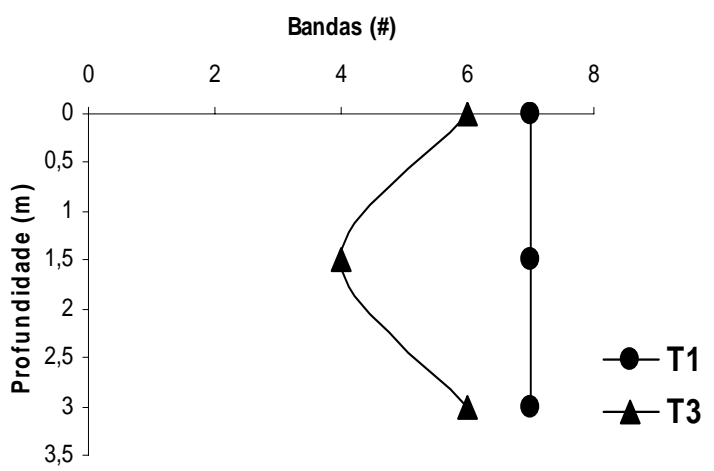

(d)

Figura 5.48: Perfis das bandas padrões do DGGE com primers pufM na lagoa anaeróbia (a: primavera, b:verão, c:outono, d:inverno)

A Figura 5.49 mostra os perfis das bandas padrões do DGGE com primers para as BRS. No verão foi verificada ligeira heterogeneidade vertical em T3, com 2 bandas na subsuperfície e interface água-sedimento, e com 4 bandas na camada intermediária. Em T1 as populações mantiveram-se constantes na coluna da água com 3 bandas. No outono foi verificada heterogeneidade vertical em T1 com 8 bandas na sub-superfície e 11 bandas na interface água-sedimento. No horário T3, nessa mesma estação foram observadas 3 bandas na sub-superfície e 7 bandas na interface água-sedimento. No inverno foi verificada heterogeneidade vertical em $\mathrm{T} 1$, com 7 bandas na sub-superfície e 2 bandas na interface 
água-sedimento. No horário T3, nessa mesma estação foram observadas 6 bandas na subsuperfície e camada intermediária, e 3 bandas na interface água-sedimento.

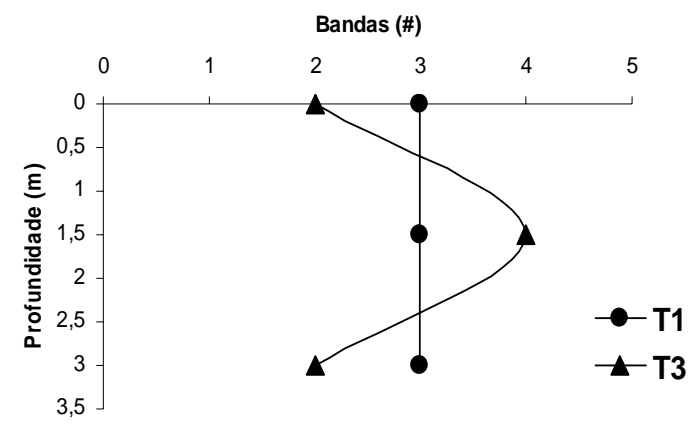

(a)

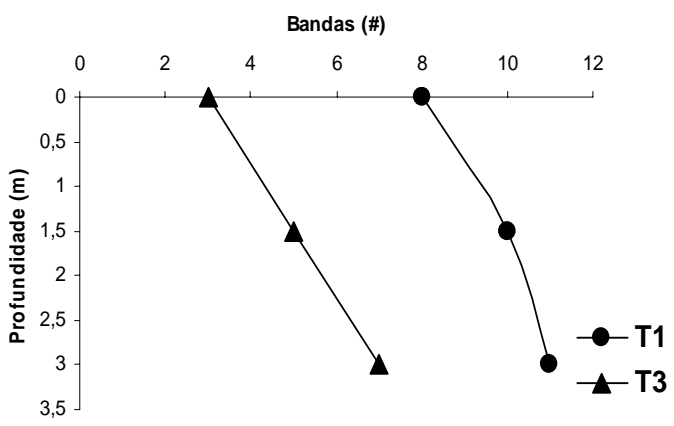

(b)

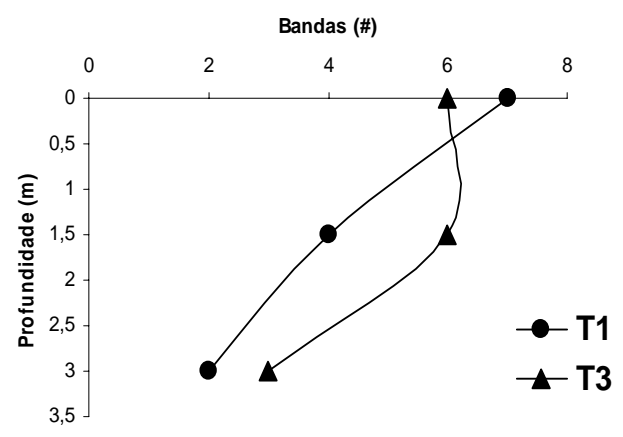

(c)

Figura 5.49: Perfis das bandas padrões do DGGE com primers para as BRS na lagoa anaeróbia (a:verão, b:outono, c:inverno) 


\subsubsection{Lagoa facultativa}

A Figura 5.50 mostra os perfis das bandas padrões do DGGE com primers para o Domínio Bacteria. Na primavera, as populações mantiveram-se com pouca variação, com 8 bandas na sub-superfície, e 9 bandas na camada intermediária e interface água-sedimento, em T1; e com 2 bandas na sub-superfície, e 4 bandas na camada intermediária e interface água-sedimento. Entre a camada intermediária e interface água-sedimento, as populações mantiveram-se constantes com 9 bandas em T1, e 4 bandas, em T3, respectivamente.

No verão foi verificada heterogeneidade vertical sendo observadas 16 bandas, na camada intermediária, e 13 bandas, na interface água-sedimento, no horário T1. No horário T3, as populações mantiveram-se constantes na sub-superfície e camada intermediária, com 13 bandas. Na interface água-sedimento foi verificada 11 bandas.

No outono as populações mantiveram-se com pouca variação na coluna da água. Em T1, foram verificadas 15 bandas na sub-superfície e interface água-sedimento; e 17 bandas na camada intermediária. Em T3 foram observadas 8 bandas, na sub-superfície e camada intermediária, e 6 bandas na interface água-sedimento. Durante a noite diminuiu o número de populações. No inverno as populações mantiveram-se constantes em T3, com 10 bandas em todos os pontos de amostragem. Em T1 foi observada uma variação pequena, com 12 bandas na sub-superfície, e 13 bandas na camada intermediária e interface água-sedimento. 


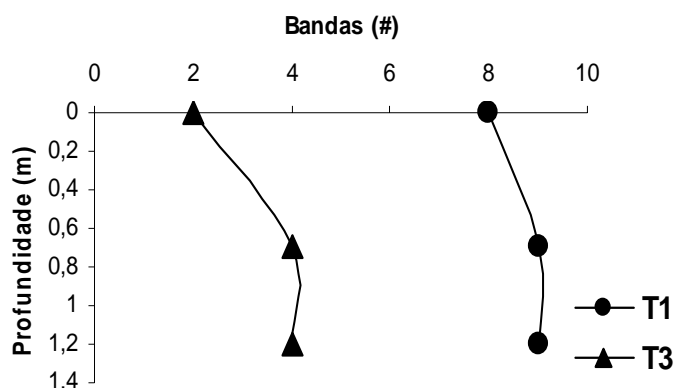

(a)

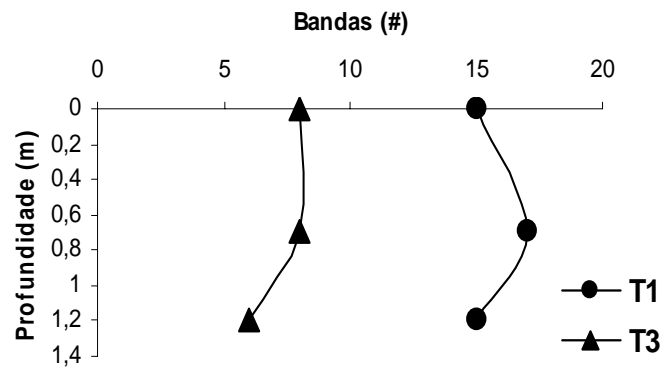

(c)

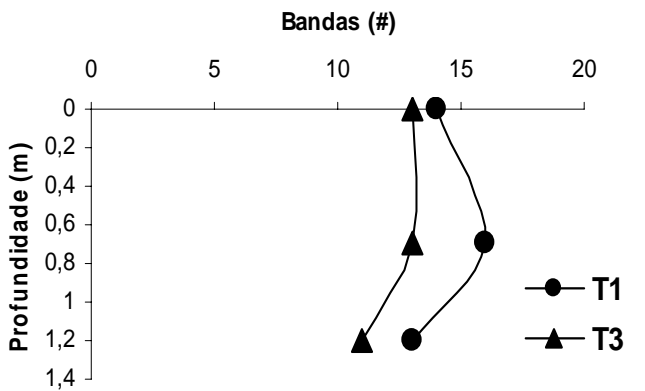

(b)

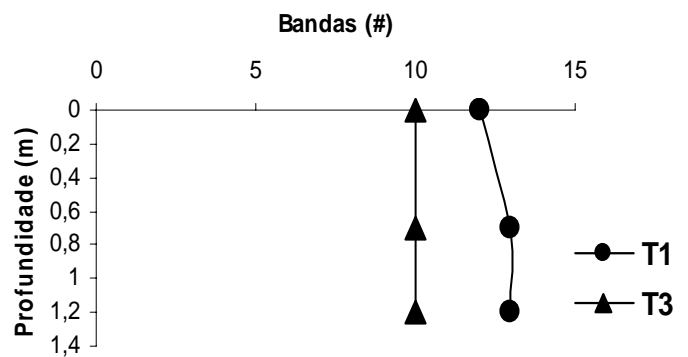

(d)

Figura 5.50: Perfis das bandas padrões do DGGE com primers para o Domínio Bacteria na lagoa facultativa (a: primavera, b:verão, c:outono, d:inverno)

A Figura 5.51 mostra os perfis das bandas padrões do DGGE com primers pufM. Na primavera, as populações de bactérias fototróficas mantiveram-se constates em todas as profundidades, para ambos os horários de coleta, com 2 bandas em T1, e 4 bandas, em T3, respectivamente.

No verão, as populações mantiveram-se constantes em ambos os horários de coleta e nas diferentes profundidades, com aparecimento de 2 bandas.

No outono, também foram verificadas constantes populações de bactérias fototróficas, com 5 bandas em T1, e com 6 bandas, em T3. No inverno foi verificada heterogeneidade vertical em T1, com 2 bandas na sub-superfície, e 5 bandas na camada intermediária e interface água-sedimento. Em T3 foi observada 4 bandas na camada intermediária, e 2 bandas na interface água-sedimento. 


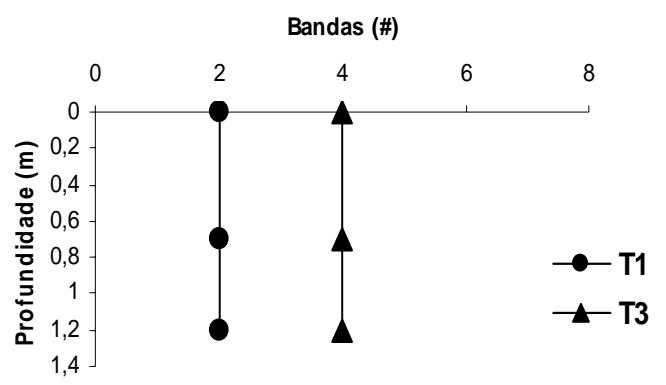

(a)

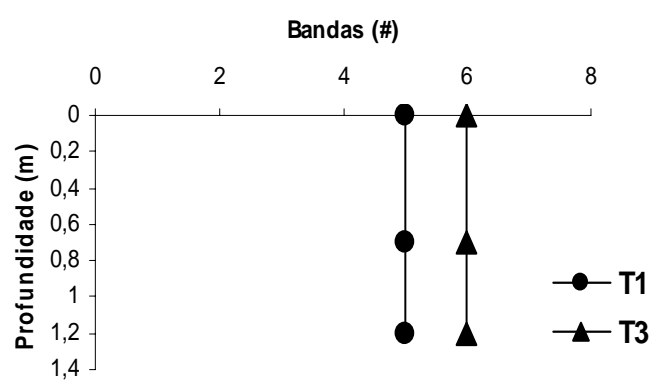

(c)

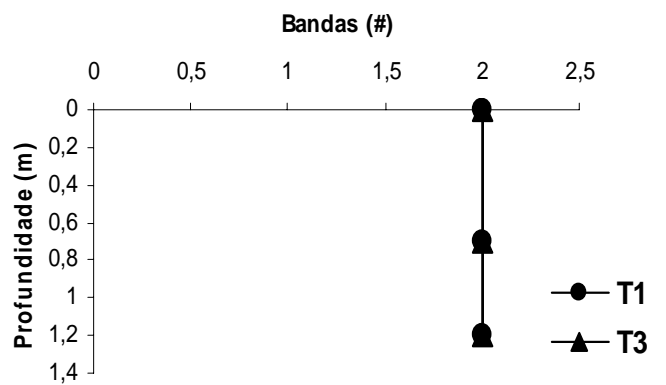

(b)

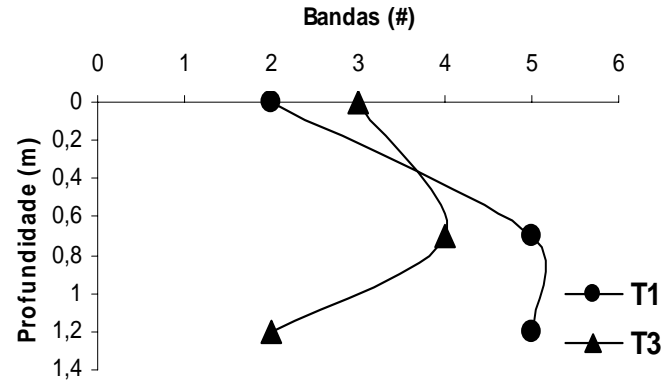

(d)

Figura 5.51: Perfis das bandas padrões do DGGE com primers pufM na lagoa facultativa (a: primavera, b:verão, c:outono, d:inverno)

A Figura 5.52 mostra os perfis das bandas padrões do DGGE com primers para as BRS. No verão foi verificada heterogeneidade vertical em T1, com 4 bandas na subsuperfície, 2 bandas na camada intermediária; e em T3, com 3 bandas na sub-superfície, 1 banda na camada intermediária. No outono foi verificada heterogeneidade vertical em T1, com 12 bandas na sub-superfície, e 9 bandas na interface água-sedimento. No inverno foi verificada heterogeneidade vertical em $\mathrm{T} 1$, com 11 bandas na camada intermediária, e 5 bandas na interface água-sedimento; em T3, com 2 bandas na sub-superfície, e 8 bandas na interface água-sedimento. 


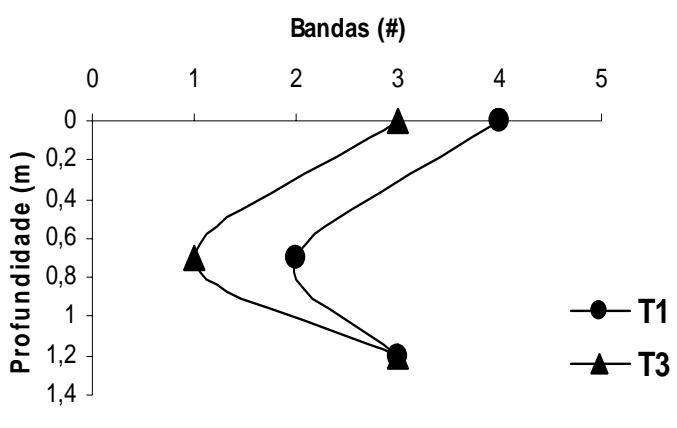

(a)

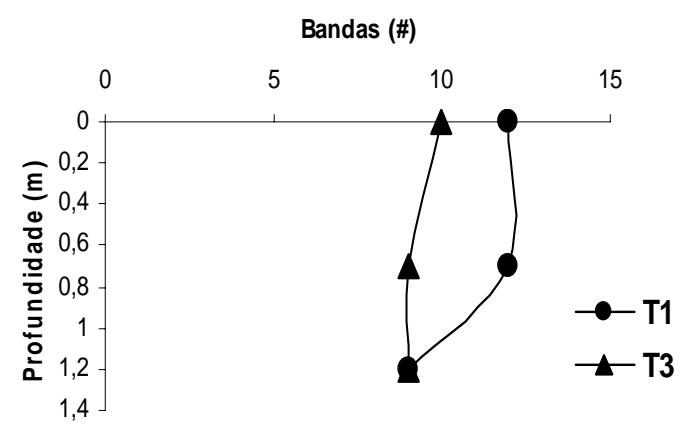

(b)

Bandas (\#)

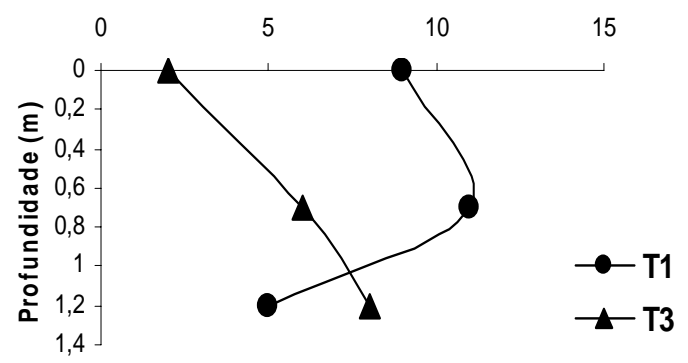

(c)

Figura 5.52: Perfis das bandas padrões do DGGE com primers para as BRS na lagoa facultativa (a:verão, b:outono, c:inverno) 


\subsection{Identificação dos microrganismos}

Nos exames microscópicos de rotina das amostras provenientes das lagoas anaeróbia e facultativa, foram observados bacilos, cocos, víbrios, cianofíceas filamentosas, algas (diatomáceas, clorofíceas) e protozoários. Dentre as bactérias, predominaram os bacilos e cocos. As principais morfologias observadas nas lagoas estão apresentadas na Figura 5.53.

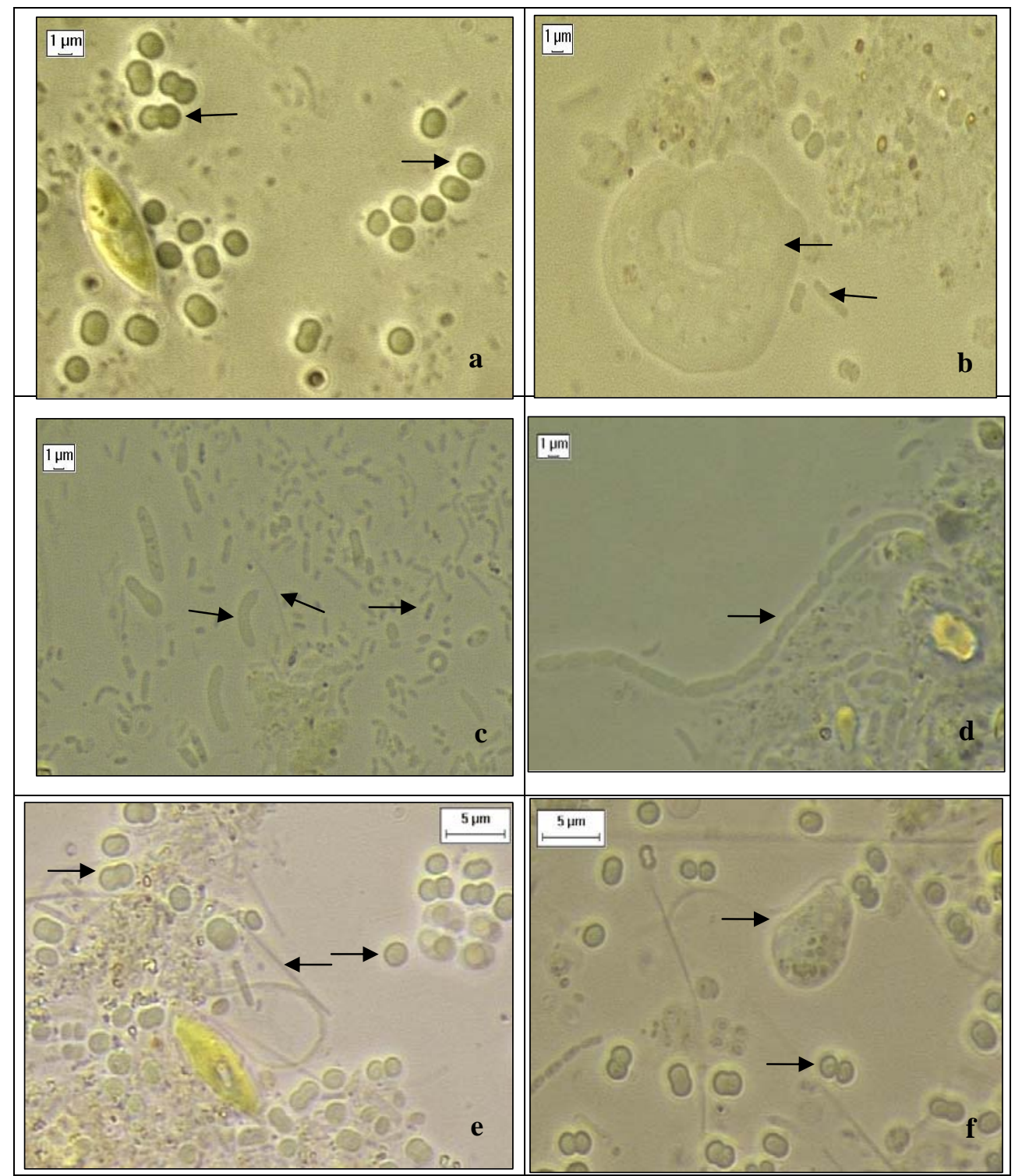

Figura 5.53: Microscopia óptica de contraste de fase de microrganismos observados na lagoa anaeróbia e na lagoa facultativa (Obj.1600X): (a) cocos e diplococos, (b) bacilos e ameba, (c) bacilos, bacilos curvos e filamentos finos, (d) bacilos em cadeia, (e) filamentos finos, cocos e diplococos, (f) protozoário e diplococos 


\subsubsection{Identificação de Bactérias}

Embora sendo visualizadas morfologias de células eucarióticas (Domínio Eucarya), neste trabalho, a identificação utilizando a análise de fragmentos do gene RNAr 16S foi realizada somente para organismos do Domínio Bacteria. Os géis das Figuras 5.54 e 5.55 mostram as bandas recortadas das amostras coletadas nas lagoas de estabilização. Os primers filogenéticos utilizados no DGGE foram 968FGC e 1392R, que amplificam fragmentos de aproximadamente $400 \mathrm{pb}$ (pares de bases) (NIELSEN et al., 1999). A diversidade do Domínio Bacteria, baseada na comparação de seqüências do RNAr 16S (MADIGAN et al., 2006), compreende as divisões Aquificales, Thermotogales, Thermus/Deinococcus, Espiroquetas, Bactérias verdes sulfurosas, Cytophagales, Planctomycetes, Chlamydia, Bactérias Gram-positivas com Baixo Teor de $\mathrm{G}+\mathrm{C}$ (guanina mais citosina), Bactérias Gram-positivas com Alto Teor de $\mathrm{G}+\mathrm{C}$ ou Actinobacteria, Cyanobacteria e Proteobacteria (bactérias púrpuras).

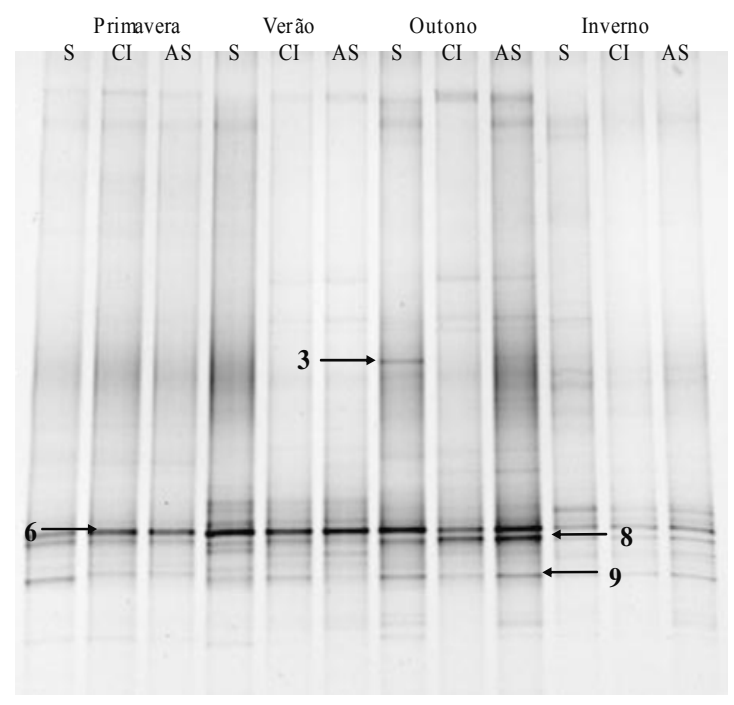

(a)

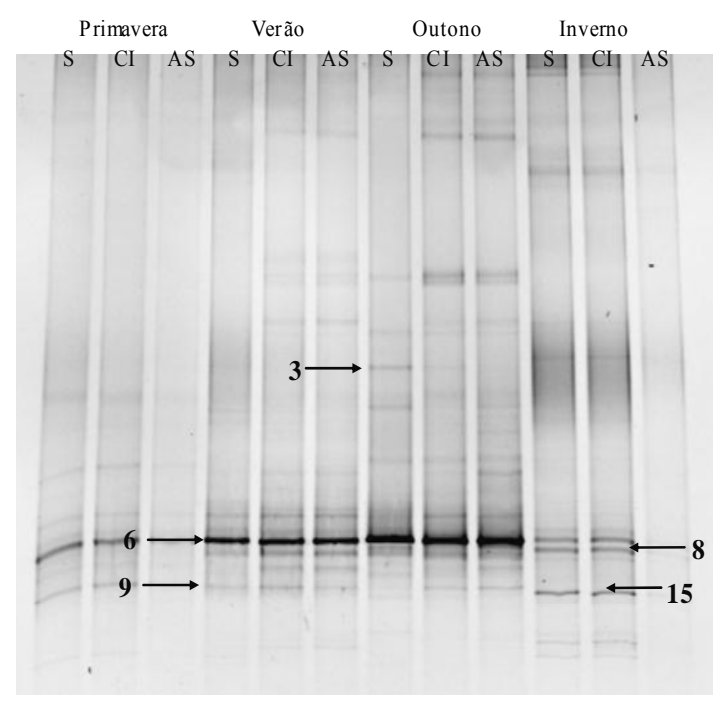

(b)

Figura 5.54: Gel de DGGE (gradiente 30\%-70\%) das variações sazonais na lagoa anaeróbia com primers para o Domínio Bacteria referente aos horários T1(a) e T3(b). $\mathrm{S}=$ sub-superfície, $\mathrm{CI}=$ camada intermediária, $\mathrm{AS}=$ interface água-sedimento 


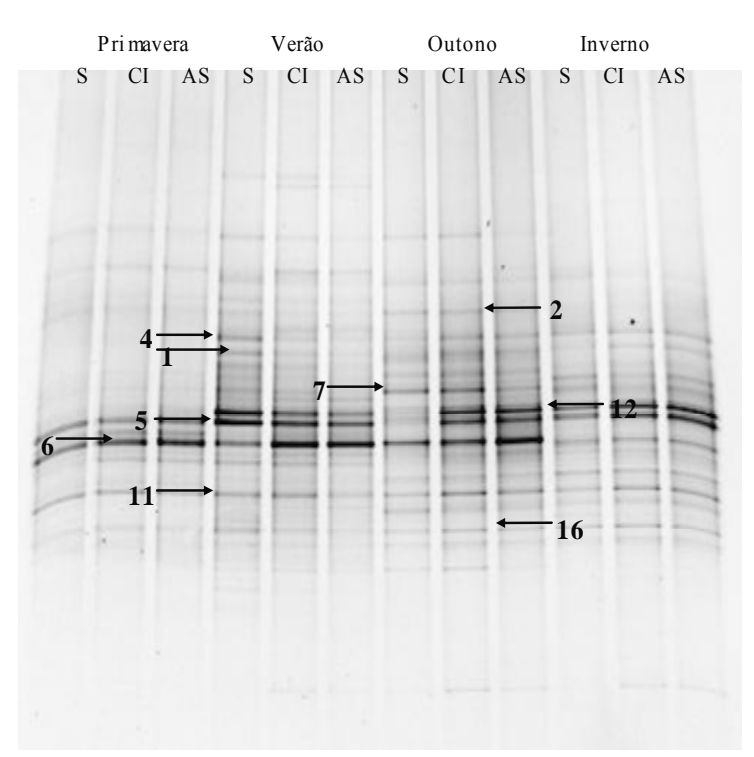

(a)

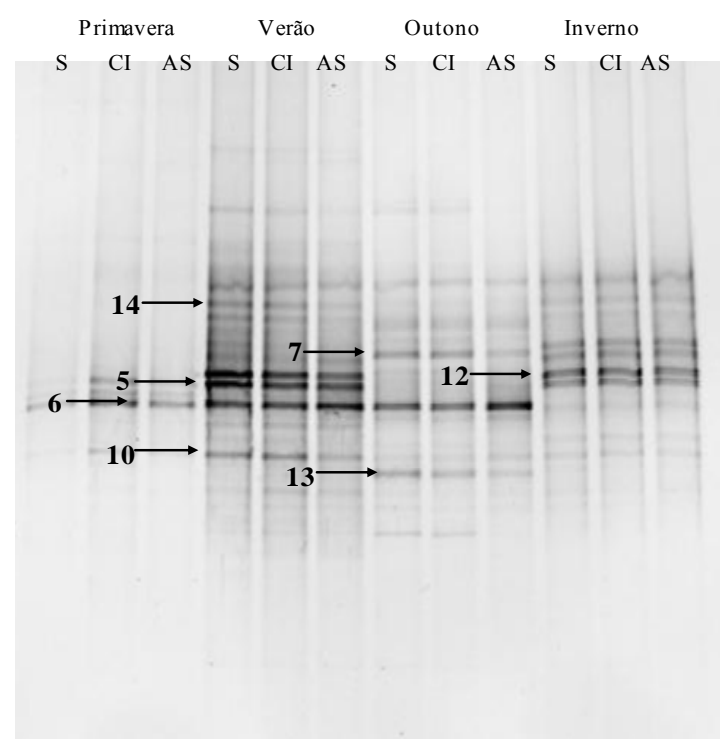

(b)

Figura 5.55: Gel de DGGE (gradiente 30\%-70\%) das variações sazonais na lagoa facultativa com primers para o Domínio Bacteria referente aos horários T1(a) e T3(b).

$\mathrm{S}=$ sub-superfície, $\mathrm{CI}=$ camada intermediária, $\mathrm{AS}=$ interface água-sedimento

A Tabela 5.10 apresenta as bactérias identificadas nas lagoas anaeróbia e facultativa nas diferentes épocas do ano e pontos de coleta.

A seqüência referente à banda 1 (Bactéria não cultivada), com similaridade de $97 \%$ foi observada na lagoa facultativa, às 14:00 $\mathrm{h}$ (T1) e verificada nas seguintes profundidades: sub-superfície e camada intermediária, no verão, e sub-superfície, camada intermediária e interface água-sedimento, no outono e inverno. A radiação solar fotossinteticamente ativa incidente na superfície da lagoa variou de $409,9 \mu \mathrm{Em}^{-2} \mathrm{~s}^{-1}$, no outono, a $1.344 \mu \mathrm{Em}^{-2} \mathrm{~s}^{-1}$, no verão. $\mathrm{O} \mathrm{pH}$ variou de 8,2 no outono, a 12,0 no verão. A temperatura variou de $19,6^{\circ} \mathrm{C}$ no inverno, a $34,3^{\circ} \mathrm{C}$ no outono. $\mathrm{O}$ oxigênio dissolvido variou de $0,02 \mathrm{mg} / \mathrm{L}$ a $9,5 \mathrm{mg} / \mathrm{L}$, ambos no verão. Esse $\mathrm{pH}$ alcalino, as temperaturas na faixa mesofílica, e as condições anaeróbias e aeróbias favoreceram o crescimento desse microrganismo na lagoa facultativa. Essa bactéria foi identificada em estudo sobre a caracterização dos microrganismos do sedimento de reservatório na China utilizando amplificação do RNAr 16S (QU et al., 2005). 
Tabela 5.10: Informação das seqüências obtidas das bandas recortadas do DGGE com primers para o Domínio Bacteria das lagoas anaeróbia e facultativa

\begin{tabular}{|c|c|c|c|c|}
\hline Banda & Microrganismo & \# acesso & Similaridade \% & Referência \\
\hline Banda 1 & Bactéria não cultivada & AY955092 & 97 & $\begin{array}{l}\text { Qu et al. (2005). } \\
\text { Não publicado (Gen } \\
\text { BanK) }\end{array}$ \\
\hline Banda 2 & Bactéria não cultivada & AF429247.1 & 99 & Sekiguchi et al. (2002) \\
\hline Banda 3 & Gama-proteobactéria não cultivada & AY664240.1 & 98 & $\begin{array}{l}\text { Jiao et al. (2004). } \\
\text { Não publicado (Gen } \\
\text { BanK) }\end{array}$ \\
\hline Banda 4 & Thauera sp. & DQ851177.1 & 90 & $\begin{array}{l}\text { Saha et al. (2006). } \\
\text { Não publicado (Gen } \\
\text { BanK) }\end{array}$ \\
\hline Banda 5 & Chromobacterium suttsuga & AY344056.1 & 95 & $\begin{array}{l}\text { Martin et al. (2003). } \\
\text { Não publicado (Gen } \\
\text { BanK) }\end{array}$ \\
\hline Banda 6 & Clostridium sp. & AF443594 & 99 & $\begin{array}{l}\text { Assih et al. (2005). } \\
\text { Não publicado (Gen } \\
\text { BanK) }\end{array}$ \\
\hline Banda 7 & Proteobactéria não cultivada & AY664120.1 & 99 & $\begin{array}{l}\text { Jiao et al. (2004). Não } \\
\text { publicado (Gen BanK) }\end{array}$ \\
\hline Banda 8 & Rhodobacter sphaeroides & СР000143 & 99 & $\begin{array}{l}\text { Copeland et al. (2005). } \\
\text { Não publicado (Gen } \\
\text { BanK) }\end{array}$ \\
\hline Banda 9 & Rhodopseudomonas palustris & СР000301 & 99 & $\begin{array}{l}\text { Copeland et al. (2006). } \\
\text { Não publicado (Gen } \\
\text { BanK) }\end{array}$ \\
\hline Banda 10 & Lampropedia hyalina & AY291119 & 97 & Lee et al. (2004) \\
\hline Banda 11 & Bacteroidetes não cultivada & AY274849.1 & 90 & Kirchman et al. (2003) \\
\hline Banda 12 & Bactéria não cultivada & DQ520192.1 & 97 & $\begin{array}{l}\text { Wu et al. (2006). } \\
\text { Não publicado (Gen } \\
\text { BanK) }\end{array}$ \\
\hline Banda 13 & Campylobacter fetus subsp. fetus & СР000487.1 & 99 & $\begin{array}{l}\text { Fouts et al. (2006). } \\
\text { Não publicado (Gen } \\
\text { BanK) }\end{array}$ \\
\hline Banda 14 & Bactéria não cultivada & AF428649.1 & 99 & Sekiguchi et al. (2002) \\
\hline Banda 15 & Beta-proteobactéria não cultivada & DQ861922 & 90 & $\begin{array}{l}\text { Rodriguez (2006). } \\
\text { Não publicado (Gen } \\
\text { BanK) }\end{array}$ \\
\hline Banda 16 & $\begin{array}{l}\text { Desulfovibrio vulgaris subsp. } \\
\text { vulgaris }\end{array}$ & AE017285.1 & 95 & Heidelberg et al. (2004) \\
\hline
\end{tabular}

A seqüência referente à banda 2 (Bactéria não cultivada), com similaridade de $99 \%$, foi verificada na lagoa facultativa, às $14: 00 \mathrm{~h}(\mathrm{~T} 1)$. Essa população foi verificada na subsuperfície, camada intermediária e interface água-sedimento das amostras obtidas no outono. Desse modo, essa bactéria foi observada em toda coluna d'água nesse período de amostragem. A radiação solar fotossinteticamente ativa incidente na superfície da lagoa, no outono, foi 409,9 $\mu \mathrm{Em}^{-2} \mathrm{~s}^{-1}$. O pH variou de 8,2, na interface água-sedimento, a 10,0 na subsuperfície. A temperatura variou de $26,5^{\circ} \mathrm{C}$ na interface água-sedimento, a $34,3^{\circ} \mathrm{C}$ na subsuperfície. $\mathrm{O}$ oxigênio dissolvido variou de $0,10 \mathrm{mg} / \mathrm{L}$ na interface água-sedimento, a 7,2 
$\mathrm{mg} / \mathrm{L}$ na sub-superfície. Essa seqüência foi verificada em estudo sobre sucessão de comunidades de microrganismos ao longo do rio Changjiang (China), utilizando o DGGE e análises de bibliotecas de clones. Os grupos identificados eram pertencentes a $\beta$ proteobactéria e Cytophaga-Flexibacter-Bacteroides com elevado conteúdo de G+C (guanina + citosina) (SEKIGUCHI et al., 2002).

A seqüência referente à banda 3 apresentou similaridade de $98 \%$ com a subdivisão Gama-proteobactéria não cultivada. Tal banda foi recortada do gel obtido às 14:00 h (T1) e às 02:00 h (T3) das amostras da sub-superfície da lagoa anaeróbia, no outono. A radiação solar fotossinteticamente ativa incidente na superfície da lagoa foi de $264,61 \mu \mathrm{Em}^{-2} \mathrm{~s}^{-1}$ $\left(14: 00\right.$ h). $\mathrm{O} \mathrm{pH}$, temperatura e oxigênio dissolvido na sub-superfície foram de $9,1,35^{\circ} \mathrm{C}$ e $8,2 \mathrm{mg} / \mathrm{L}$, respectivamente. Em T3 $(02: 00 \mathrm{~h})$, estes valores foram de 7,$8 ; 30,5^{\circ} \mathrm{C}$ e 0,14 $\mathrm{mg} / \mathrm{L}$, respectivamente. Essas condições verificadas na sub-superfície da lagoa anaeróbia foram favoráveis para o desenvolvimento desse microrganismo. Essa bactéria pode representar um organismo alóctone que esteve presente na sub-superfície da lagoa anaeróbia, ou seja, não sendo originários desse local, chegam ao ambiente aquático através do ar, solo, esgoto sanitário ou água residuária industrial (ESTEVES, 1988). Tal seqüência foi verificada em estudo sobre a diversidade de bactérias fototróficas anoxigênicas realizado no oceano Pacífico norte sub-tropical (JIAO et al., 2004).

A seqüência referente à banda 4 foi relacionada com $90 \%$ de similaridade a Thauera sp. Essa banda foi observada nas amostras obtidas às 14:00 h (T1) da lagoa facultativa, na sub-superfície e camada intermediária, no verão, e na sub-superfície, camada intermediária e interface água-sedimento, no outono e inverno. Esse microrganismo foi favorecido pelas mesmas condições nutricionais apresentadas na descrição da seqüência da banda 1 (Bactéria não cultivada) e observadas nessa mesma lagoa. Thauera sp. representa os organismos desnitrificantes, Gram negativos, da divisão proteobactéria. Tais células foram identificadas em estudo sobre a diversidade de bactérias cultiváveis de amostras aquáticas (SAHA et al., 2006). A presença de bactérias semelhantes a Thauera sp. foi verificada no outono e inverno, nas três profundidades amostradas na lagoa facultativa. Entretanto, no verão foi observada somente na sub-superfície e na camada intermediária. Nesses diferentes períodos, os valores de nitrato, nitrito e matéria orgânica (DQOb) oscilaram entre 1,3-2,6 $\mathrm{mg} / \mathrm{L}, 1,1-23,4 \mathrm{mg} / \mathrm{L}$ e 93,9-174,3 mg/L, respectivamente. 
A maioria das bactérias desnitrificantes caracterizadas estão incluídas no grupo conhecido como Proteobacteria (bactéria púrpura), que apresenta 5 subdivisões: alfa $(\alpha)$, beta $(\beta)$, gama $(\gamma)$, delta $(\delta)$ e epsilon $(\varepsilon)$. Os organismos desnitrificantes são encontrados em 4 destas subdivisões $(\alpha, \beta, \gamma$ e $\varepsilon)$. O principal critério de inclusão foi a capacidade de formar óxidos de nitrogênio gasoso (CANHOS et al., 1999).

Bactérias desnitrificantes utilizam diferentes fontes de energia; ou seja, orgânica (organotróficos), inorgânica (litotróficos) e luz (fototróficos). Os substratos orgânicos são as fontes de energia mais comumente utilizadas por este grupo (ZEHNDER, 1988). Além da variedade de produtos naturais que são tipicamente utilizados como fonte de carbono, a decomposição de certos compostos de origem antropogênica, pelas bactérias desnitrificantes tem sido observada. Nos últimos anos, têm se consolidado as informações de que bactérias desnitrificantes podem metabolizar compostos aromáticos, e muitas delas pertencem ao gênero Thauera (SHIEH e MULCAHY, 1986). A presença de tais bactérias na lagoa facultativa foi relacionada com a utilização de compostos orgânicos como doadores de elétrons para a redução de nitrito e nitrato no metabolismo desnitrificante.

A seqüência referente à banda 5 foi verificada na sub-superfície, camada intermediária e interface água-sedimento, no primeiro horário de coleta (14:00 h - T1), nas quatro épocas do ano, em amostras da lagoa facultativa. No segundo horário (02:00 h - T3 ) de coleta esta foi verificada, também nas mesmas profundidades, todavia, somente na primavera, verão e inverno, na mesma lagoa. Tal seqüência foi relacionada com $95 \%$ de similaridade a Chromobacterium suttsuga. Esse microrganismo foi também identificado por Martin et al. (2003), em estudo sobre o controle biológico da batata. O crescimento desses microrganismos pode ter sido favorecido pela presença de insetos provenientes dos cultivos, por exemplo, de banana e ervas (chá) localizados em regiões próximas às lagoas de estabilização. A exploração agrícola da região do Vale do Ribeira é voltada para a bananicultura, pastagem e ervagem.

A seqüência referente à banda 6 foi verificada na lagoa anaeróbia e na lagoa facultativa, nos dois horários de coleta $(14: 00 \mathrm{~h}$ - T1 e 02:00 h - T3). Essa seqüência apresentou similaridade de 99\% com Clostridium sp. Nas amostras da coleta diurna (14:00 h) foi verificada nas três profundidades de amostragem e nas quatro épocas do ano. Todavia, não foi observada na amostragem realizada no inverno, na lagoa facultativa e nem 
na interface água-sedimento da lagoa anaeróbia, no período noturno $(02: 00 \mathrm{~h}) . \mathrm{O} \mathrm{pH}$ na sub-superfície variou de 7,0 no outono, a 12,0 no verão. A temperatura variou de $19,6^{\circ} \mathrm{C}$ no inverno, a $35,1^{\circ} \mathrm{C}$ no outono. $\mathrm{O}$ oxigênio dissolvido variou de $0,0 \mathrm{mg} / \mathrm{L}$ na primavera, a 9,5 $\mathrm{mg} / \mathrm{L}$ no verão. Em função da sua distribuição, estas bactérias podem representar parte da comunidade autóctone comum em ambas as lagoas.

Espécies de Clostridium são bacilos Gram positivos, formadores de endósporos, usualmente quimioorganotróficos. Produzem gás hidrogênio, ácidos orgânicos e álcoois a partir de carboidratos ou peptonas. Podem metabolizar carboidratos, álcoois, aminoácidos, purinas, esteróides e outros compostos orgânicos. Algumas espécies fixam nitrogênio atmosférico, enquanto outras realizam metabolismo fermentativo. Foram verificadas em estudo sobre a caracterização de isolados bacterianos no sistema digestivo de térmitas (ASSIH et al., 2005).

Relatos interessantes, relacionados com o crescimento de Clostridium, foram verificados por Kawasaki et al. (1998). Os autores observaram que Clostridium butyricum apresentou habilidade de crescer na presença de oxigênio. Após o consumo de todo o oxigênio dissolvido $(40,0 \mu \mathrm{M}$ e $120 \mu \mathrm{M})$, e posterior estabelecimento das condições anaeróbias, foi capaz de crescer nesse ambiente sem que fossem observados danos celulares. Portanto, essa versatilidade metabólica justificou a presença desse gênero de bactéria nas três profundidades amostradas, no horário diurno, onde variações na concentração de oxigênio dissolvido foram de a $0,0 \mathrm{mg} / \mathrm{L}$ (primavera) a 9,5 mg/L (verão).

A seqüência referente à banda 7 foi relacionada com $99 \%$ de similaridade à divisão Proteobacteria (célula não cultivada). Essa banda foi observada nas três profundidades na lagoa facultativa, no outono e inverno, em ambos os horários de coleta (14:00 h - T1 e 02:00 h - T3). A radiação solar fotossinteticamente ativa incidente na superfície da lagoa esteve na faixa de 409,9 $\mu \mathrm{Em}^{-2} \mathrm{~s}^{-1}$ e $519,8 \mu \mathrm{Em}^{-2} \mathrm{~s}^{-1}$, respectivamente. O $\mathrm{pH}$ variou de 7,4 a 10,3 no outono e inverno, respectivamente. A temperatura variou de $19,6^{\circ} \mathrm{C}$ no inverno, a $34,3^{\circ} \mathrm{C}$ no outono. O oxigênio dissolvido variou de $2,9 \mathrm{mg} / \mathrm{L}$ a $7,2 \mathrm{mg} / \mathrm{L}$ ambos no outono, respectivamente. Tal microrganismo compartilhou das condições nutricionais similares às observadas para a seqüência constatada na banda 1 (Bactéria não cultivada) e banda 4 (Thauera sp.). Essa seqüência foi verificada no estudo de bactérias fototróficas anoxigênicas aeróbias em água costeira, na China (JIAO et al., 2004). 
A seqüência referente à banda 8 foi relacionada a Rhodobacter sphaeroides, com similaridade de 99\%. Essa bactéria foi verificada na lagoa anaeróbia, nos dois horários e nas três profundidades nas quatro épocas do ano, com exceção observada somente na primavera, no horário de coleta das 02:00 h. A radiação solar fotossinteticamente ativa incidente na superfície da lagoa anaeróbia, às $14: 00 \mathrm{~h}$, variou de $245,5 \mu \mathrm{Em}^{-2} \mathrm{~s}^{-1}$ no verão a $574,8 \mu \mathrm{Em}^{-2} \mathrm{~s}^{-1}$ no inverno. O pH variou de 6,8 no outono, a 10,9 no verão. A temperatura variou de $19,6^{\circ} \mathrm{C}$ no inverno, a $35,1^{\circ} \mathrm{C}$ no outono. O oxigênio dissolvido variou de 0,0 $\mathrm{mg} / \mathrm{L}$ na primavera, a $8,22 \mathrm{mg} / \mathrm{L}$ no outono. Rhodobacter sphaeroides é uma bactéria fototrófica púrpura não sulfurosa, Gram negativa, da divisão Proteobacteria. Apresenta crescimento fotoheterotrófico em condições anaeróbias, usando ampla variedade de compostos orgânicos como fontes de carbono (glicose, frutose, glutamato, citrato, gliconato, etanol) e doadores de elétrons. $\mathrm{Na}$ fotossíntese anoxigênica, absorvem energia nos comprimentos de onda da faixa de $372 \mathrm{~nm}$ a $880 \mathrm{~nm}$. A temperatura ótima para o seu crescimento varia de $30^{\circ} \mathrm{C}$ a $34^{\circ} \mathrm{C}$, e o $\mathrm{pH}$ de 6,0 a 8,5 . Este representante da comunidade de bactérias autóctones da lagoa anaeróbia foi identificado em uma pesquisa sobre seqüência completa do cromossomo 1 de Rhodobacter sphaeroides (COPELAND et al., 2005).

A seqüência referente à banda 9 apresentou $99 \%$ de similaridade a Rhodopseudomonas palustris. Essa banda foi observada nos dois horários de coleta, nas amostras provenientes da lagoa anaeróbia. Em T1 (14:00 h), esta banda foi verificada nas três profundidades e nas diferentes épocas do ano. Em T3 $(02: 00 \mathrm{~h})$, foi verificada na subsuperfície, camada intermediária e interface água-sedimento, na primavera e verão; e na camada intermediária e interface água-sedimento, no outono. Todavia, nesse horário de coleta $(02: 00 \mathrm{~h})$, não foi observada a sua presença no inverno. A radiação solar fotossinteticamente ativa incidente na superfície da lagoa variou de $245,5 \mu \mathrm{Em}^{-2} \mathrm{~s}^{-1}$ no verão a $574,8 \mu \mathrm{Em}^{-2} \mathrm{~s}^{-1}$ no inverno. $\mathrm{O} \mathrm{pH}$ variou de 6,8 no outono, a 10,9 no verão. A temperatura variou de $19,6^{\circ} \mathrm{C}$ no inverno, a $35,1^{\circ} \mathrm{C}$ no outono. $\mathrm{O}$ oxigênio dissolvido variou de $0,0 \mathrm{mg} / \mathrm{L}$ na primavera, a $8,2 \mathrm{mg} / \mathrm{L}$ no outono.

Rhodopseudomonas palustris é uma bactéria fototrófica púrpura não sulfurosa, Gram negativa. O seu crescimento fotoautotrófico é possível com utilização de hidrogênio, sulfito e tiossulfato como doadores de elétrons, na presença de extrato de levedura. O 
crescimento fotoheterotrófico ocorre na presença de vários substratos orgânicos, tais como benzoato, acetato, piruvato, malato, fumarato, lactato e succinato. Essas bactérias absorvem luz nos comprimentos de onda compreendidos na faixa entre $375 \mathrm{~nm}$ a $875 \mathrm{~nm}$. A temperatura ótima para o seu crescimento varia de $30^{\circ} \mathrm{C}$ a $37^{\circ} \mathrm{C}$, e o $\mathrm{pH}$ de 5,5 a 8,5 . Tais bactérias podem crescer sob condições microaeróbias e aeróbias no escuro, ou em condições anaeróbias e em presença de alguns substratos orgânicos. O sulfato pode ser usado como fonte de enxofre, enquanto a amônia, dinitrogênio e alguns aminoácidos são usados como fontes de nitrogênio (MADIGAN et al., 2006). É parte da comunidade bacteriana autóctone da lagoa anaeróbia e pode ser responsável por florescimentos nas lagoas de estabilização, proporcionando cor púrpura à superfície. Foi identificada em estudo sobre a seqüência completa de Rhodopseudomonas palustris (COPELAND et al., 2006).

A identificação dessa seqüência compatível a Rhodopseudomonas palustris foi realizada, também, usando os primers pufM.557F e pufM.750R, específicos para amplificação parcial (229 pares de bases) do centro de reação fotossintético das bactérias fototróficas púrpuras, operon pufM, universalmente distribuído nesse grupo de microrganismos fototróficos anoxigênicos. Além disso, em ensaios de purificação celular com utilização amostras das lagoas de estabilização foi possível constatar a presença de tais células em meio de cultivo fotoheterotrófico.

A seqüência referente à banda 10 foi relacionada a Lampropedia hyalina (DSM 15336), com similaridade de $97 \%$. Sua presença foi verificada em toda a coluna d'água da lagoa facultativa, nas amostras obtidas às 02:00 h (T3). Nesse período, os valores de $\mathrm{pH}$ encontravam-se na faixa de 9,7 (interface água-sedimento) a 11,3 (sub-superfície). A temperatura variou de $25,5^{\circ} \mathrm{C}$ na interface água-sedimento, a $28,7^{\circ} \mathrm{C}$ na camada intermediária. $\mathrm{O}$ oxigênio dissolvido variou de $0,08 \mathrm{mg} / \mathrm{L}$ (interface água-sedimento) a 3,2 mg/L (camada intermediária). Provavelmente esta bactéria represente parte da comunidade alóctone da lagoa facultativa. Lampropedia hyalina é um microrganismo Gram-negativo, quimioheterotrófico, encontrado em diferentes habitats. Pertence ao grupo das $\beta$ proteobactérias e foi identificada em um estudo das características fenotípicas, quimiotaxonômicas e moleculares (análise do RNAr 16S) de três variedades de 
Lampropedia hyalina. Está presente em amostras de águas contaminadas, ricas em matéria orgânica e no rúmen ou sistema digestivo de alguns animais (LEE et al., 2004).

A seqüência referente à banda 11 foi relacionada à Bacteroidetes não cultivado, com similaridade de $90 \%$. Sua presença foi verificada na lagoa facultativa, nas três profundidades de amostragem e nas diferentes épocas do ano, obtidas às 14:00 h (T1). A radiação solar fotossinteticamente ativa incidente na superfície da lagoa facultativa variou de $221,3 \mu \mathrm{Em}^{-2} \mathrm{~s}^{-1}$ na primavera, a $1.344 \mu \mathrm{Em}^{-2} \mathrm{~s}^{-1}$ no verão. $\mathrm{O} \mathrm{pH}$ variou de 8,2 no outono, a 12,0 no verão. A temperatura variou de $19,6^{\circ} \mathrm{C}$ no inverno, a $34,3^{\circ} \mathrm{C}$ no outono. $\mathrm{O}$ oxigênio dissolvido variou de $0,05 \mathrm{mg} / \mathrm{L}$ na primavera, a $9,5 \mathrm{mg} / \mathrm{L}$ no verão. Essa bactéria se manteve em condições nutricionais similares às verificadas para a banda 5 (Chromobacterium suttsuga). Bacteroidetes é uma bactéria Gram negativa encontrada nas fezes de animais de sangue quente. São vetores de doenças diversas, como a colite, enterecolite e diverticulite e foram identificadas em estudos da diversidade de CytophagaFlavobacterium, realizados no estuário em Delaware (Océano Ártico), utilizando a hibridização in situ (FISH). Esse microrganismo predomina em sistemas aquáticos devido à sua capacidade de degradar a matéria orgânica (KIRCHMAN et al., 2003).

A seqüência referente à banda 12 (Bactéria não cultivada), com similaridade de 97\%, foi observada nas amostras da lagoa facultativa, nos dois horários de coleta e nas três profundidades de amostragem, no verão e inverno. Todavia, no outono foi verificada apenas na camada intermediária e na interface água-sedimento, nas amostras obtidas às 14:00 h. A radiação solar fotossinteticamente ativa incidente na superfície da lagoa facultativa, no horário das 14:00 h, foi de $1.344 \mu \mathrm{Em}^{-2} \mathrm{~s}^{-1}$ (verão) e $519,8 \mu \mathrm{Em}^{-2} \mathrm{~s}^{-1}$ (inverno). O pH variou de 9,0 na primavera, a 12,0 no verão. A temperatura variou de $19,6^{\circ} \mathrm{C}$ no inverno, a $32,6^{\circ} \mathrm{C}$ no verão. $\mathrm{O}$ oxigênio dissolvido variou de $0,02 \mathrm{mg} / \mathrm{L}$ no verão, a $6,2 \mathrm{mg} / \mathrm{L}$ no inverno. O microrganismo esteve presente em condições nutricionais similares às verificadas para a banda 1 (Bactéria não cultivada), banda 4 (Thauera sp.) e banda 7 (Proteobactéria - célula não cultivada). Foi identificado por Wu et al. (2006), mediante análise do RNAr 16S, de amostra proveniente de um lago na China.

A seqüência referente à banda 13 apresentou similaridade de $99 \%$ em relação à Campylobacter fetus subsp. fetus. Essa bactéria foi observada na lagoa facultativa, nas três profundidades, nas amostras obtidas às $02: 00 \mathrm{~h}(\mathrm{~T} 3)$, no outono. $\mathrm{O} \mathrm{pH}$ variou de 7,4 na 
interface água-sedimento, a 8,3 na sub-superfície. A temperatura variou de $27,8^{\circ} \mathrm{C}$ (interface água-sedimento) a $30,6^{\circ} \mathrm{C}$ (sub-superfície). O oxigênio dissolvido variou de 0,03 $\mathrm{mg} / \mathrm{L}$ (interface água-sedimento) a $2,3 \mathrm{mg} / \mathrm{L}$ (sub-superfície). Campylobacter fetus é um bacilo Gram negativo, na forma de S, com motilidade. É um patógeno oportunista em seres humanos e causa infecção sistêmica e intestinal. Segundo Fouts, et al. (2006), é transmitido por alimentos contaminados. Esse microrganismo é também transmitido por fezes, leite e água contaminada (BLASER et al., 1980). Portanto, à luz destas observações, deve ter sido proveniente do esgoto doméstico afluente à lagoa de estabilização.

A seqüência referente à banda 14 (Bactéria não cultivada), com similaridade de $90 \%$, foi recortada do gel obtido das amostras coletadas às 02:00 $\mathrm{h}$ (T3), na lagoa facultativa, no verão e inverno, e nas diferentes profundidades. Compartilharam condições nutricionais similares às verificadas para a banda 10 (Lampropedia hyalina) e banda 12 (Bactéria não cultivada). Foi identificada como constituinte da subdivisão $\beta$-proteobactéria, em um estudo de sucessão da comunidade de microrganismos ao longo do rio Changjiang (China) (SEKIGUCHI et al., 2002).

A seqüência referente à banda 15 (Beta-proteobactéria não cultivada), com similaridade de $90 \%$ foi observada nas amostras da camada intermediária e interface águasedimento da lagoa anaeróbia, obtidas às 02:00 h (T3), no inverno. Nesse período, os valores de $\mathrm{pH}$ estiveram na faixa de 8,3 a 9,0, a temperatura era de $19,6^{\circ} \mathrm{C}$, e oxigênio dissolvido variou de $0,14 \mathrm{mg} / \mathrm{L}$ a $0,29 \mathrm{mg} / \mathrm{L}$. Seqüência similar foi identificada em amostras provenientes de um reator de leito fluidizado, usado no tratamento de água contaminada com óleo diesel, proveniente de água subterrânea (RODRIGUEZ et al., 2006).

A seqüência referente à banda 16 (Desulfovibrio vulgaris subsp. vulgaris), com similaridade de $95 \%$, foi observada nas amostras da lagoa facultativa, nas diferentes profundidades e nas quatro épocas do ano. Essa bactéria compartilhou condições nutricionais similares às observadas para a banda 5 (Chromobacterium suttsuga) e banda 11 (Bacteroidetes não cultivado).

Desulfovibrio vulgaris é uma bacteria Gram negativa, que apresenta motilidade. A temperatura ótima para o seu crescimento está na faixa de $25-35^{\circ} \mathrm{C}$, existindo variedades que podem crescer a $0^{\circ} \mathrm{C}$; o pH favorável está ao redor de 7,5. Não formam endósporos, são denominadas de bactérias redutoras de sulfato e, sob tais condições crescem 
preferencialmente na presença de lactato. Raramente utilizam carboidratos e pertencem à subdivisão $\delta$-proteobactéria. Habitam diferentes ambientes, tais como os de água doce, marinho, intestino de animais e fezes. É considerado um organismo modelo para o estudo do metabolismo energético das BRS, relacionado com o impacto econômico causado na corrosão de estruturas metálicas e biorremediação de metais tóxicos (urânio e cromo). A redução enzimática de metais por espécies de Desulfovibrio sp. tem importante influência na geoquímica de sedimentos e a bactéria pode ser útil para remover metais presentes na água contaminada (HEIDELBERG et al., 2004). Esses microrganismos formam consórcios microbianos complexos, encarregados dos processos de digestão anaeróbia no tratamento de águas residuárias industriais e esgoto sanitário. Muitos estudos demonstraram que as BRS não somente toleram elevadas concentrações de oxigênio dissolvido, mas também podem utilizar o oxigênio como aceptor final de elétrons (BEN-DOV et al., 2006).

A presença de bactérias semelhantes a Desulfovibrio na lagoa facultativa justificase, principalmente, em função da possibilidade de crescimento desta sob diferentes concentrações de oxigênio. $\mathrm{O}$ oxigênio dissolvido variou de $0,05 \mathrm{mg} / \mathrm{L}$ na primavera, a 9,54 mg/L no verão. Johnson et al. (1997) avaliaram o crescimento de Desulfovibrio vulgaris em diferentes concentrações de oxigênio dissolvido, variando de $0,0 \%$ a $0,08 \%$. O meio de cultura utilizado continha $6,0 \mathrm{~g} / \mathrm{L}$ de lactato e 3,0 g/L de sulfato como doador e aceptor de elétrons, respectivamente, e $2,5 \times 10^{8}$ células $/ \mathrm{mL}$ de Desulfovibrio vulgaris. A temperatura ambiente foi de $37^{\circ} \mathrm{C}$, e as concentrações específicas de oxigênio foram combinadas com mistura de $\mathrm{H}_{2} / \mathrm{CO}_{2} / \mathrm{N}_{2}$ (10/10/80\%). Os autores verificaram que Desulfovibrio vulgaris cresceu na prsença de oxigênio dissolvido variando de $0,02 \%$ a $0,04 \%(0,24$ a $0,48 \mu \mathrm{M})$.

Além dessas possibilidades de crescimento, Johnson et al. (1997) verificaram que as células de Desulfovibrio podem migrar (aerotaxia) para regiões com gradiente de sulfeto e oxigênio; ou seja, onde a concentração de oxigênio é baixa, mas não o suficiente para se manter condições anaeróbias. Isso pode indicar que essas células não somente toleram baixas concentrações de oxigênio dissolvido, mas também podem preferir a presença de oxigênio durante seu crescimento. Linhagens de Desulfovibrio exibem velocidades de respiração comparáveis com as verificadas para crescimento de bactérias aeróbias. Os pesquisadores postularam que a aerotaxia em $D$. vulgaris pode ser um mecanismo de defesa frente à presença de oxigênio dissolvido no ambiente anaeróbio. Portanto, migram para as 
regiões oxigenadas e, mediante a rápida respiração, reduzem o oxigênio da água. Esse mecanismo pode ter uma função ecológica importante nas zonas de transição de ambiente aeróbio e anaeróbio.

A Figura 5.56 mostra a árvore filogenética de consenso com primers para o Domínio Bacteria proveniente da informação de seqüências obtidas das lagoas de estabilização.

Os valores dos coeficientes de similaridade verificados entre os diferentes grupos de microrganismos observados nas lagoas de estabilização, variando de 90 a 99\%, indicaram a presença de diferentes espécies relacionadas filogeneticamente nas lagoas, a partir da avaliação parcial de suas seqüências do gene RNAr 16S. Na construção da mencionada árvore filogenética, foram acrescentadas seqüências conhecidas de Streptococcus pyogenes (NC_002737), Clostridium perfringens (BA000016), Escherichia coli (NC_002695), Salmonella enterica (NC_006905) e de Pseudomonas aeruginosa (NC_002516). 


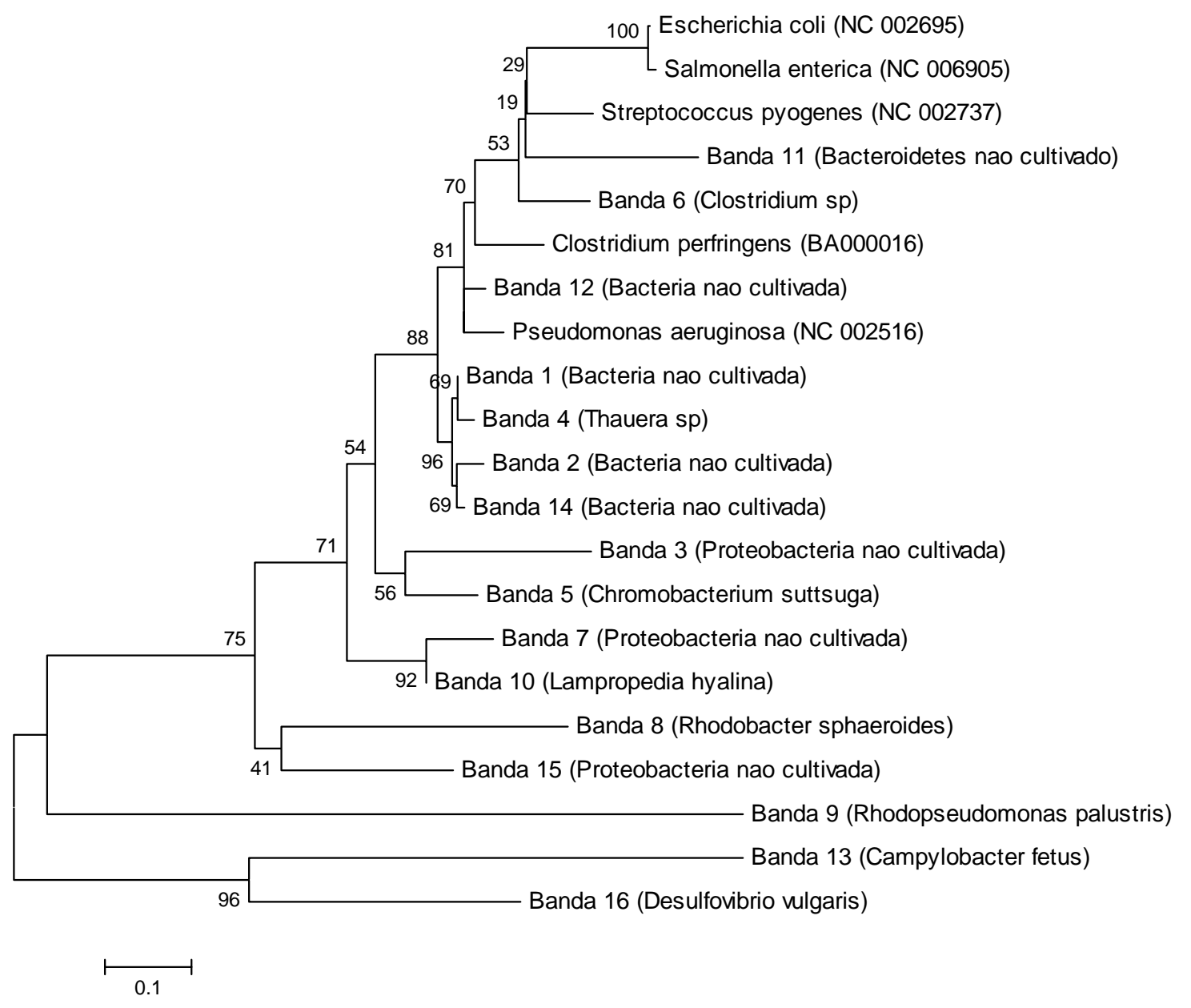

Figura 5.56: Árvore filogenética de consenso baseado nas seqüências das bandas recortadas do DGGE com primers para o Domínio Bacteria, obtidas das lagoas anaeróbia e facultativa. Os valores presentes nos nós das árvores indicam porcentagens que o ramo se repitiu (500 reamostragens de bootstraps) 


\subsubsection{Identificação de Bactérias Fototróficas Anoxigênicas}

Os géis das Figuras 5.57 e 5.58 mostram o perfil do DGGE e a indicação das bandas recortadas para identificação. Na reação em cadeia da polimerase foram utilizados os primers pufM.557FGC e pufM.750R, específicos para amplificação parcial (229 pares de bases) do centro de reação fotossintético das bactérias fototróficas púrpuras, operon puf $\mathrm{M}$, universalmente distribuído nesse grupo de microrganismos fototróficos anoxigênicos (ACHENBACH et al. 2001). O uso em conjunto dos primers universais para o Domínio Bacteria (968F e 1392R), que amplifica uma região específica do RNAr 16S, com os primers pufM.557F e pufM.750R, confirmaram a presença de bactérias fototróficas nas lagoas de estabilização, tais como Rhodopseudomonas palustris (99\%). Todavia, somente com a utilização dos primers universais, que amplificam fragmentos de aproximadamente $400 \mathrm{pb}$ (pares de bases), foi possível constatar seqüência compatível a Rhodobacter sphaeroides (99\%). Em contrapartida, com o uso de primers específicos para o centro fotossintético das bactérias fototróficas púrpuras foi possível constatar seqüências semelhantes a Chromatium vinosum, Roseobacter sp., Thiocapsa sp., Rhodospirillum rubrum, Chromatium sp.e Rhodopseudomonas palustris.

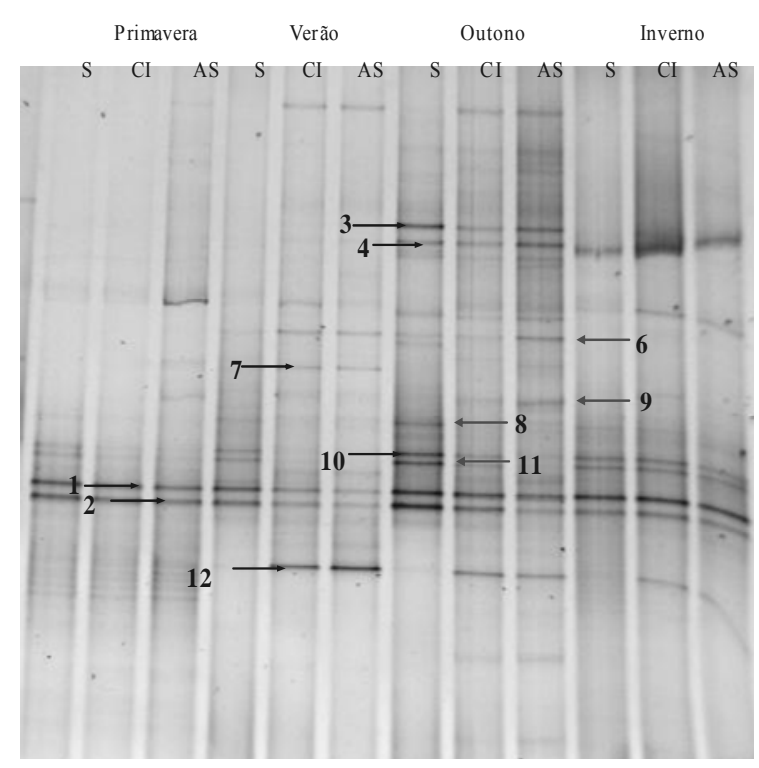

(a)

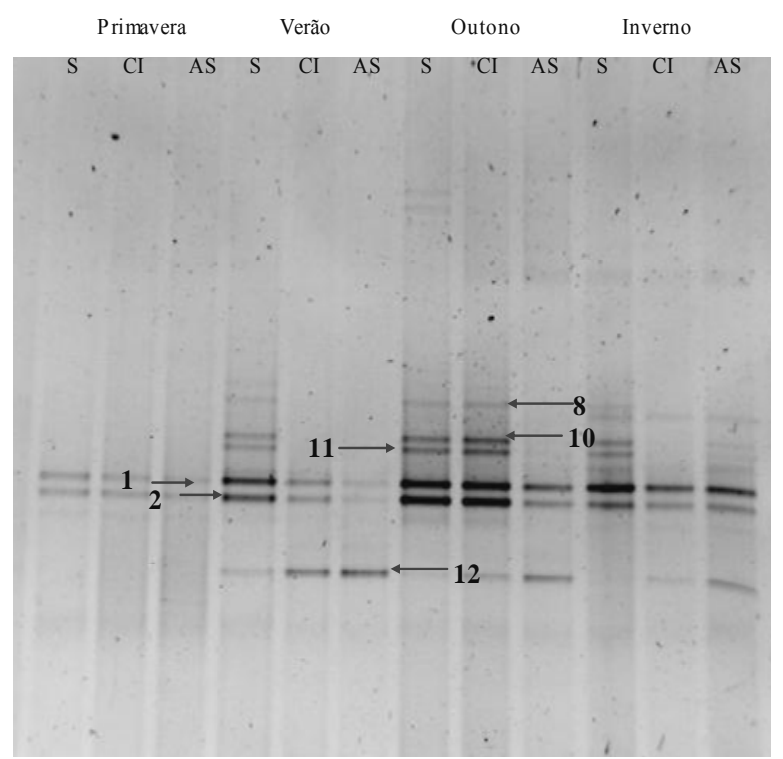

(b)

Figura 5.57: Gel de DGGE (gradiente 20\%-80\%) das variações sazonais na lagoa anaeróbia com primers puf $\mathrm{M}$ referente aos horários: $\mathrm{T} 1(\mathrm{a})$ e $\mathrm{T} 3$ (b).

$\mathrm{S}=$ sub-superfície, $\mathrm{CI}=$ camada intermediária, $\mathrm{AS}=$ interface água-sedimento 


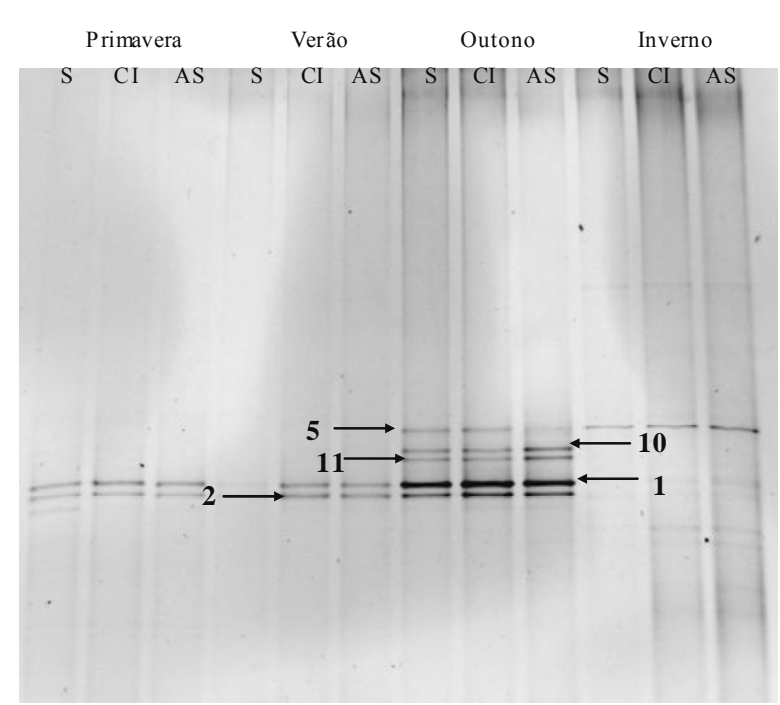

(a)

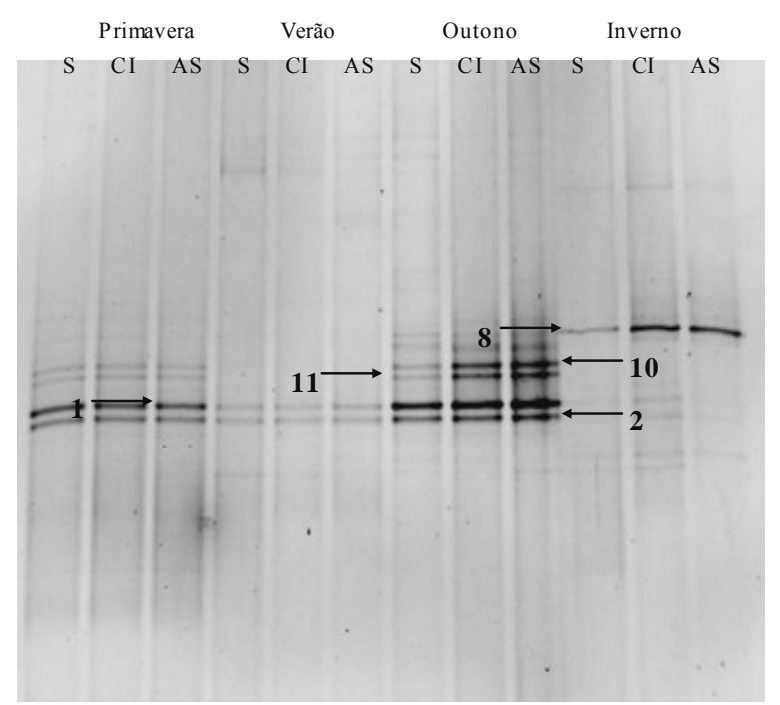

(b)

Figura 5.58: Gel de DGGE (gradiente 20\%-80\%) das variações sazonais na lagoa facultativa com primers puf $\mathrm{M}$ referente aos horários: $\mathrm{T} 1$ (a) e $\mathrm{T} 3$ (b). $\mathrm{S}=$ sub-superfície, $\mathrm{CI}=$ camada intermediária, $\mathrm{AS}$ = interface água-sedimento

A Tabela 5.11 apresenta a descrição das bactérias fototróficas identificadas nas lagoas anaeróbia e facultativa, nas diferentes épocas do ano e diferentes profundidades.

A seqüência referente à banda 1 apresentou $92 \%$ de similaridade com Cromatium vinosum. Essa banda foi observada nas duas lagoas de estabilização. Na lagoa anaeróbia foi verificada em toda coluna d'água nos dois horários de coleta, nas quatro épocas do ano. Todavia, na lagoa facultativa não foi verificada no inverno. Nas demais estações do ano, na lagoa facultativa, apresentou comportamento similar ao observado na lagoa anaeróbia. Cromatium vinosum é uma bactéria fototrófica púrpura sulfurosa, Gram negativa. Apresenta grânulos de enxofre intracelular durante o crescimento fotoautotrófico na presença de sulfeto de hidrogênio. Em condições microaerófilas, cresce sob condições quimioautotróficas e mixotróficas. Além disso, pode crescer sob condições fotoheterotróficas na presença de acetato de amônia. A temperatura ótima para o seu crescimento varia de $30-35^{\circ} \mathrm{C}$, enquanto o $\mathrm{pH}$ adequado encontra-se na faixa de 6,5-7,6. A radiação solar fotossinteticamente ativa incidente na superfície das lagoas, às 14:00 $\mathrm{h}$, variou de $221,3 \mu \mathrm{Em}^{-2} \mathrm{~s}^{-1}$ na primavera, a $1.344 \mu \mathrm{Em}^{-2} \mathrm{~s}^{-1}$ no verão. $\mathrm{O} \mathrm{pH}$ variou de 6,8 no outono, a 12,0 no verão. A temperatura variou de $19,6^{\circ} \mathrm{C}$ no inverno, a $35,1^{\circ} \mathrm{C}$ no outono. $\mathrm{O}$ oxigênio dissolvido variou de $0,0 \mathrm{mg} / \mathrm{L}$ na primavera e outono, a $9,5 \mathrm{mg} / \mathrm{L}$ no verão. Foi identificada em pesquisa sobre a estrutura primária de genes que codificam proteínas do 
centro fotossintético em bactérias fotossintéticas púrpuras (NAGASHIMA et al., 1998). Esse microrganismo, que suporta condições de microaerofilia, possivelmente utilizou compostos de enxofre e ácidos orgânicos como doadores de elétrons na fotossíntese anoxigênica. Quando usa sulfeto no crescimento fotoautotrófico acumula enxofre intracelular, o qual será oxidado culminando com o incremento de sulfato no meio reacional. Geralmente, tais bactérias crescem próximas às BRS, e ambas participam ativamente por meio de relações sintróficas no estabelecimento do ciclo do enxofre. Nas lagoas de estabilização a concentração de sulfato variou de $1,0 \mathrm{mg} / \mathrm{L}$ no outono a 28,0 $\mathrm{mg} / \mathrm{L}$ na primavera.

Tabela 5.11: Informação das seqüências obtidas das bandas recortadas do DGGE com primers pufM das lagoas anaeróbia e facultativa

\begin{tabular}{|c|c|c|c|c|}
\hline Banda & Microrganismo & \# acesso & $\begin{array}{c}\text { Similaridade } \\
\%\end{array}$ & Referência \\
\hline Banda 1 & Chromatium vinosum & ABO11811.1 & 92 & Nagashima (1998) \\
\hline Banda 2 & Roseobacter sp. & AY675565.1 & 91 & Oz et al. (2005) \\
\hline Banda 3 & Bactéria não cultivada & AM162697.1 & 99 & $\begin{array}{l}\text { Ranchou-Peyruse et al. } \\
\text { (2006) }\end{array}$ \\
\hline Banda 4 & Bactéria não cultivada & AY044247.1 & 89 & Beja et al. (2002) \\
\hline Banda 5 & Thiocapsa $\mathrm{sp}$. & AJ544223.2 & 90 & Wieland et al. (2003) \\
\hline Banda 6 & Bactéria não cultivada & AM162737.1 & 88 & $\begin{array}{l}\text { Ranchou-Peyruse et al. } \\
\text { (2006) }\end{array}$ \\
\hline Banda 7 & Bactéria não cultivada & DQ080988.1 & 89 & $\begin{array}{l}\text { Yutin et al. (2000). Não } \\
\text { publicado (Gen BanK) }\end{array}$ \\
\hline Banda 8 & Rhodospirillum rubrum & AY390602.1 & 95 & Lee et al. (2003) \\
\hline Banda 9 & Bactéria não cultivada & AY044246.1 & 90 & Beja et al. (2002) \\
\hline Banda 10 & Chromatium sp. & D50647.1 & 91 & Nagashima et al. (1997) \\
\hline Banda 11 & Roseobacter sp. & AY675566.1 & 93 & Oz et al. (2005) \\
\hline Banda 12 & Rhodopseudomonas palustris & AB015977.1 & 99 & Beja et al. (2002) \\
\hline
\end{tabular}

A seqüência referente à banda 2 apresentou similaridade de $91 \%$ com Roseobacter sp. Essa banda foi observada nas amostras coletadas nos dois horários e nas duas lagoas. $\mathrm{Na}$ lagoa anaeróbia foi encontrada na sub-superfície, camada intermediária e interface águasedimento, nas quatro épocas do ano. Na lagoa facultativa foi observada na sub-superfície, camada intermediária e interface água-sedimento, na primavera, verão e outono. Roseobacter sp. é uma bactéria Gram negativa, com motilidade (um ou dois flagelos), pertencente ao grupo $\alpha$-proteobactéria. Apresenta crescimento em ampla faixa de temperatura, variando de $15^{\circ} \mathrm{C}-37^{\circ} \mathrm{C}$, e de $\mathrm{pH}$, entre $7,0-10,0$. Não cresce na ausência de cloreto de sódio $(\mathrm{NaCl})$ e requer diferentes fatores de crescimento. Utiliza vários compostos como fonte de carbono; tais como D-manose, D-galactose, D-frutose, D-glicose, D-xilose, 
entre outros. É comum em ambientes aquáticos, todavia realiza fotossíntese anoxigênica aeróbia. As bactérias que realizam fotossíntese anoxigênica aeróbia requerem oxigênio para crescimento e síntese da bacterioclorofila $a(\mathrm{Bchl} a)$. Esses microrganismos não são capazes de crescer em condições fotoautotróficas estritas, pois requerem suplemento de carbono orgânico.

Esse microrganismo foi verificado sob as mesmas condições nutricionais mencionadas na descrição da banda 1 , e foi identificado em estudo de organismos fotossintéticos anoxigênicos no mediterrâneo, por meio de primers pufM (OZ et al., 2005).

A seqüência referente à banda 3 (Bactéria não cultivada), com similaridade de $99 \%$, foi recortada do gel obtido às 14:00 h (T1) das amostras da lagoa anaeróbia coletadas na sub-superfície, camada intermediária e interface água-sedimento, no outono. A radiação solar fotossinteticamente ativa incidente na superfície da lagoa, no horário T1, nessa época, foi de $264,61 \mu \mathrm{Em}^{-2} \mathrm{~s}^{-1}$. O pH variou de 7,0 na interface água-sedimento a 9,1 na subsuperfície. A temperatura variou de $26,2^{\circ} \mathrm{C}$ na interface água-sedimento, a $35,1^{\circ} \mathrm{C}$ na subsuperfície. $\mathrm{O}$ oxigênio dissolvido variou de $0,0 \mathrm{mg} / \mathrm{L}$ na camada intermediária, a 8,2 $\mathrm{mg} / \mathrm{L}$ na sub-superfície. Possivelmente, esta foi uma bactéria eventual na lagoa anaeróbia. Essa seqüência foi identificada em uma pesquisa sobre diversidade de bactérias fototróficas púrpuras anoxigênicas no sedimento de um lago eutrófico (RANCHOU-PEYRUSE et al., 2006). Os autores utilizaram métodos moleculares, aplicando primers puf $\mathrm{M}$ e métodos tradicionais de obtenção de culturas de bactérias do ambiente. Isolaram oito variedades de bactérias fototróficas púrpuras não sulfurosas, três bactérias púrpuras sulfurosas e duas variedades de Roseobacter sp. (RANCHOU-PEYRUSE et al., 2006).

A seqüência referente à banda 4 (Bactéria não cultivada), com similaridade de $89 \%$, foi observada nas amostras referente às 14:00 h (T1) da lagoa anaeróbia, da sub-superfície, camada intermediária e interface água-sedimento, no outono. Esse microrganismo foi verificado nas mesmas condições nutricionais verificadas para a banda 3 (Bactéria não cultivada). Possivelmente represente uma bactéria eventual na lagoa anaeróbia. Foi identificada em pesquisa sobre a diversidade de bactérias fototróficas anoxigênicas aeróbias marinhas (BEJA et al., 2002).

A seqüência referente à banda 5 apresentou similaridade de $90 \%$ com Thiocapsa sp. Tal seqüência foi observada na amostra obtida às 14:00 h (T1) da sub-superfície, camada 
intermediária e interface água-sedimento, no outono e inverno, da lagoa facultativa. No outono, a radiação solar fotossinteticamente ativa incidente na superfície da lagoa foi de $409,9 \mu \mathrm{Em}^{-2} \mathrm{~s}^{-1}$ e no inverno, 519,8 $\mu \mathrm{Em}^{-2} \mathrm{~s}^{-1}$. O pH variou de 8,2 no outono, a 10,3 no inverno. A temperatura variou de $19,6^{\circ} \mathrm{C}$ no inverno, a $34,3^{\circ} \mathrm{C}$ no outono. $\mathrm{O}$ oxigênio dissolvido variou de $0,10 \mathrm{mg} / \mathrm{L}$ a $7,2 \mathrm{mg} / \mathrm{L}$, ambos no outono.

Thiocapsa sp. é uma bactéria fototrófica púrpura sulfurosa, Gram negativa. Em condições anaeróbias, apresenta crescimento fototrófico. Em condições aeróbias ou microaerófilas apresenta crescimento quimioautotrófico ou quimioorganotrófico, no escuro. A temperatura ótima para o seu crescimento varia de $20-35^{\circ} \mathrm{C}$, e o $\mathrm{pH}$ de $6,5-7,5$. Foi verificada em estudo de comunidades de microrganismos do sedimento das ilhas de OrKney (Nova Zelândia). Nessa pesquisa, Wieland et al. (2003), avaliaram a composição de ácidos graxos, hidrocarbonetos e álcoois. Os autores observaram a presença de diferentes grupos de bactérias e algas no sedimento, tais como diatomáceas, cianobactérias e BRS. Mediante o T-RFLP (polimorfismo do comprimento de restrição dos fragmentos terminais), avaliaram a distribuição vertical dos microrganismos ao longo do sedimento. Sob tal abordagem, verificaram diferentes populações de bactérias púrpuras e BRS, tais como Thiocapsa roseopersicina, Allochromatium vinosum e espécies de Desulfovibrio sp. Segundo os autores, as bactérias púrpuras sulfurosas liberaram sulfato, o qual foi utilizado como aceptor de elétrons na respiração anaeróbia das BRS levando à produção de sulfeto. Esse último composto foi usado por bactérias fototróficas como doador de elétrons na fotossíntese anoxigênica (WIELAND et al., 2003).

No presente trabalho, também foram observadas células semelhantes à Desulfobrio (seqüência referente à banda 16 - Desulfovibrio vulgaris subsp. vulgaris) na lagoa facultativa, nas três profundidades, nas quatro épocas do ano. Provavelmente, Desulfovibrio vulgaris e Thiocapsa sp. estabeleceram relações sintróficas para utilização dos compostos de enxofre presentes na lagoa facultativa.

A seqüência referente à banda 6 (Bactéria não cultivada), com similaridade de $88 \%$, foi observada na camada intermediária e interface água-sedimento, no verão; e na interface água-sedimento, no outono, na lagoa anaeróbia $(14: 00 \mathrm{~h}, \mathrm{~T} 1)$. A radiação solar fotossinteticamente ativa incidente na superfície da lagoa anaeróbia, no verão (horário T1), foi de $245,5 \mu \mathrm{Em}^{-2} \mathrm{~s}^{-1}$ e no outono, $264,1 \mu \mathrm{Em}^{-2} \mathrm{~s}^{-1}$. O pH variou de 7,0 no outono, a 9,2 no 
verão. A temperatura variou de $25,2^{\circ} \mathrm{C}$ no verão, a $26,2^{\circ} \mathrm{C}$ no outono. $\mathrm{O}$ oxigênio dissolvido variou de $0,0 \mathrm{mg} / \mathrm{L}$ no outono, a $0,1 \mathrm{mg} / \mathrm{L}$ no verão. Possivelmente represente uma bactéria eventual na lagoa. Essa seqüência foi observada em estudo de bactérias fototróficas púrpuras anoxigênicas no sedimento de um lago eutrófico (RANCHOU-PEYRUSE et al., 2006).

A seqüência referente à banda 7 (Bactéria não cultivada), com similaridade de $89 \%$, foi verificada na camada intermediária e interface água-sedimento, no verão (14:00 h, T1), na lagoa anaeróbia. A radiação solar fotossinteticamente ativa incidente na superfície da lagoa anaeróbia, às 14:00 $\mathrm{h}$, no verão foi $245,5 \mu \mathrm{Em}^{-2} \mathrm{~s}^{-1} \mathrm{O} \mathrm{pH}$ na camada intermediária foi de 9,2 ; temperatura de $25,3^{\circ} \mathrm{C}$, e oxigênio dissolvido de $0,1 \mathrm{mg} / \mathrm{L}$. $\mathrm{O} \mathrm{pH}$ na interface águasedimento foi de 9,2 ; temperatura de $25,2^{\circ} \mathrm{C}$, e oxigênio dissolvido de $0,08 \mathrm{mg} / \mathrm{L}$. Possivelmente represente uma bactéria eventual na lagoa, que contribui na degradação da matéria orgânica. Foi verificada em pesquisa sobre novos primers para avaliar a diversidade de bactérias em ambiente marinho (YUTIN et al., 2000).

A seqüência referente à banda 8 apresentou similaridade de $95 \%$ com Rhodospirillum rubrum. Tal banda foi verificada na sub-superfície e camada intermediária da lagoa anaeróbia, no outono, em ambos os horários de coleta. A radiação solar fotossinteticamente ativa incidente na superfície da lagoa anaeróbia, às 14:00 h, no outono, foi de $264,61 \mu \mathrm{Em}^{-2} \mathrm{~s}^{-1}$. O pH variou de 7,0 na camada intermediária, a 9,1 na subsuperfície. A temperatura variou de $26,5^{\circ} \mathrm{C}$ na camada intermediária, a $35,1^{\circ} \mathrm{C}$ na subsuperfície. $\mathrm{O}$ oxigênio dissolvido variou de $0,0 \mathrm{mg} / \mathrm{L}$ na camada intermediária, a $8,2 \mathrm{mg} / \mathrm{L}$ na sub-superfície. Rhodospirillum rubrum é uma bactéria fototrófica anoxigênica púrpura não sulfurosa, Gram negativa. Tais bactérias crescem preferencialmente em condições anaeróbias fotoheterotróficas, na presença de vários compostos orgânicos como fonte de carbono e elétrons. A temperatura ótima para o seu crescimento varia de $30-35^{\circ} \mathrm{C}$, e o pH de $6,0-8,5$. O comprimento de onda em que absorvem varia de $375 \mathrm{~nm}$ a $885 \mathrm{~nm}$. Foram identificadas em estudo realizado sobre o centro fotossintético das bactérias fototróficas anoxigênicas (LEE et al., 2003).

A seqüência referente à banda 9 (Bactéria não cultivada), com similaridade de $90 \%$, foi verificada na interface água-sedimento da lagoa anaeróbia, no outono (14:00 h, T1). A radiação solar fotossinteticamente ativa incidente na superfície da lagoa, às 14:00 h, no 
outono, foi de $264,61 \mu \mathrm{Em}^{-2} \mathrm{~s}^{-1}$. O pH na interface água-sedimento foi de 6,8 ; temperatura de $27,1^{\circ} \mathrm{C}$ e oxigênio dissolvido de $0,04 \mathrm{mg} / \mathrm{L}$. Representa uma espécie esporádica na lagoa e foi verificada em estudo da diversidade de bactérias fototróficas anoxigênicas de ambiente marinho (BEJA et al., 2002).

A seqüência referente à banda 10 apresentou similaridade de $91 \%$ com Chromatium sp. Essa banda foi verificada nas duas lagoas, nos dois horários de coleta. Na lagoa anaeróbia, no horário $\mathrm{T} 1$, foi observada na sub-superfície, na primavera e verão; na subsuperfície e camada intermediária, no outono; e na sub-superfície, camada intermediária e interface água-sedimento, no inverno. No horário T3, foi verificada na sub-superfície, no verão; na sub-superfície e camada intermediária, no outono; e na sub-superfície, no inverno. Na lagoa facultativa, no horário T1, foi observada na sub-superfície, camada intermediária e interface água-sedimento, no outono. No horário T3, foi verificada nas diferentes profundidades, na primavera e outono. A radiação solar fotossinteticamente ativa incidente na superfície variou de $245,5 \mu \mathrm{Em}^{-2} \mathrm{~s}^{-1}$ no verão, a $574,8 \mu \mathrm{Em}^{-2} \mathrm{~s}^{-1}$ no inverno. $\mathrm{O}$ $\mathrm{pH}$ variou de 7,0 no outono, a 10,9 no verão. A temperatura variou de $19,6^{\circ} \mathrm{C}$ no inverno, a $35,1^{\circ} \mathrm{C}$ no outono. $\mathrm{O}$ oxigênio dissolvido variou de $0,0 \mathrm{mg} / \mathrm{L}$ no outono, a $8,2 \mathrm{mg} / \mathrm{L}$ no inverno. É parte da comunidade de bactérias autóctone em ambas as lagoas. Cromatium sp. é uma bactéria anaeróbia fototrófica púrpura sulfurosa, identificada em pesquisa sobre a estrutura primária de genes que codificam proteínas do centro fotossintético em bactérias fotossintéticas púrpuras (NAGASHIMA et al., 1997).

A seqüência referente à banda 11 apresentou similaridade de $93 \%$ com Roseobacter sp. Tal banda foi observada em ambas as lagoas, nos dois horários de coleta. Na lagoa anaeróbia, no horário $\mathrm{T} 1$, foi observada na sub-superfície na primavera e verão; na subsuperfície e camada intermediária no outono; e na sub-superfície, camada intermediária e interface água-sedimento, no inverno. No horário T3, foi verificada na sub-superfície, no verão; na sub-superfície e camada intermediária, no outono; e na sub-superfície, no inverno. Na lagoa facultativa, no horário T1, foi observada na sub-superfície, camada intermediária e interface água-sedimento, no outono. No horário T3, foi verificada nas diferentes profundidades, na primavera e outono, nessa mesma lagoa. As condições nutricionais que favoreceram o seu crescimento foram iguais às observadas na descrição da banda 10 (Chromatium sp., similaridade de 91\%). Ambas foram favorecidas pelas 
diferentes variações de $\mathrm{pH}$, temperatura e oxigênio dissolvido. É parte da comunidade de bactérias autóctones de ambas as lagoas. Roseobacter sp. é uma bactéria Gram negativa, fototrófica anoxigênica, identificada em estudo de organismos fotossintéticos anoxigênicos no mediterrâneo, utilizando primers puf $\mathrm{M}$ e bacterioclorofilas $b c h \mathrm{X}$ e $b c h \mathrm{~L}$ como marcadores moleculares (OZ et al., 2005).

A seqüência referente à banda 12 apresentou similaridade de $99 \%$ com Rhodopseudomonas palustris. Essa banda foi verificada na camada intermediária e interface água-sedimento, no verão e outono, na lagoa anaeróbia em ambos os horários de coleta. A radiação solar fotossinteticamente ativa incidente na superfície da lagoa anaeróbia, às 14:00 h, no outono, foi de $264,61 \mu \mathrm{Em}^{-2} \mathrm{~s}^{-1}$. O pH variou de 6,8 na interface água-sedimento, a 7,1 na camada intermediária. A temperatura variou de $26,2^{\circ} \mathrm{C}$ na interface água-sedimento, a $27,6^{\circ} \mathrm{C}$ na camada intermediária. $\mathrm{O}$ oxigênio dissolvido variou de $0,0 \mathrm{mg} / \mathrm{L}$ na camada intermediária, a $0,04 \mathrm{mg} / \mathrm{L}$ na interface água-sedimento. Rhodopseudomonas palustris é uma bactéria fototrófica púrpura não sulfurosa, Gram negativa, versátil metabolicamente, e pode apresentar crescimento fotoautotrófico, fotoheterotrófico e quimiotrófico. A temperatura ótima para o seu crescimento varia de 30$37^{\circ} \mathrm{C}$, e pH de 5,5-8,5. Absorve em comprimento de onda na faixa de $375 \mathrm{~nm}$ a $875 \mathrm{~nm}$. Foi verificada em estudo da diversidade de fototróficos anoxigênicos marinhos (BEJA et al., 2002).

$\mathrm{Na}$ purificação celular realizada com as amostras das lagoas de estabilização, especificamente com amostra da sub-superfície da lagoa anaeróbia, coletada na primavera, foi possível constatar o predomínio de Rhodopseudomonas palustris (similaridade de 92\%). As condições nutricionais que favoreceram o crescimento dessas células foram as seguintes: 1,5 g/L de acetato de amônia como fonte de carbono e 10,0 g/L de extrato de levedura, como fonte de nitrogênio e vitaminas. Esse meio enriquecido, com pH de 7,0 a 7,2 , temperatura de $30^{\circ} \mathrm{C} \pm 1^{\circ} \mathrm{C}$, sob condições anaeróbias e na presença de luz (4000-5000 lux) permitiram a obtenção dessas bactérias. 
A Figura 5.59 apresenta a árvore filogenética de consenso proveniente da informação de seqüências obtidas das lagoas de estabilização.

Os valores dos coeficientes de similaridade, obtidos com utilização dos primers pufM, variando de $88 \%$ a $99 \%$, indicaram grupos de microrganismos diversos filogeneticamente, devido, possivelmente, à transferência vertical de genes do centro fotossintético, que acontece entre as bactérias fotossintéticas (KARR et al., 2003).

$\mathrm{Na}$ realização da árvore foram acrescentadas seqüências conhecidas de Rhodopseudomonas palustris (AB015977), Rhodospirillum rubrum (J03731) e de Chromatium vinosum (D50647).

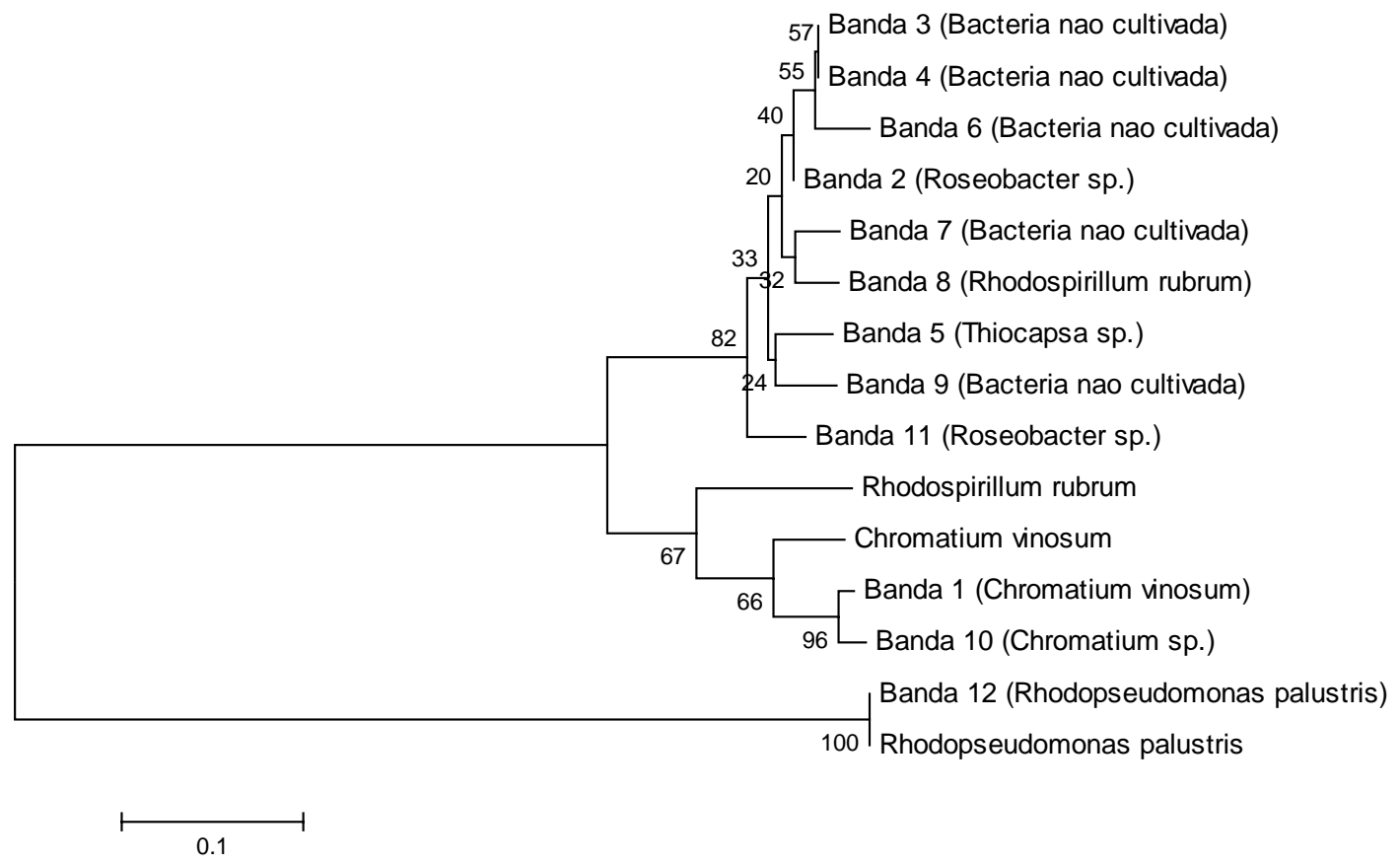

Figura 5.59: Árvore filogenética de consenso baseada nas seqüências das bandas recortadas do DGGE com primers do centro fotossintético pufM, obtidas das lagoas anaeróbia e facultativa. Os valores presentes nos nós das árvores indicam porcentagens que o ramo se repitiu (500 reamostragens de bootstraps) 


\subsubsection{Identificação de Bactérias Redutoras de Sulfato}

Os géis das Figuras 5.60 e 5.61 mostram as bandas recortadas das amostras das lagoas de estabilização. Os primers utilizados na amplificação por PCR foram 341FGC e 907R (NAKAGAWA et al., 2002), os quais amplificam regiões diferentes do gene RNAr 16S ao amplificado pelos primers para o Domínio Bacteria (968FGC e 1392R) (NIELSEN et al., 1999). Os primers 341FGC e 907R são utilizados para avaliar, também, microrganismos do Domínio Bacteria, inclusive microrganismos pertencentes ao sub-grupo $\delta$-proteobactéria, representado por diferentes bactérias redutoras de sulfato.

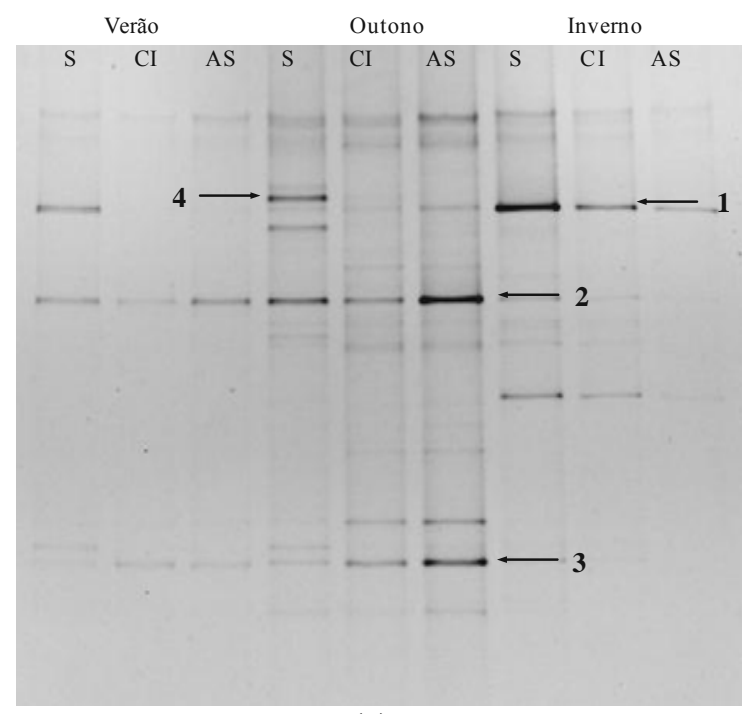

(a)

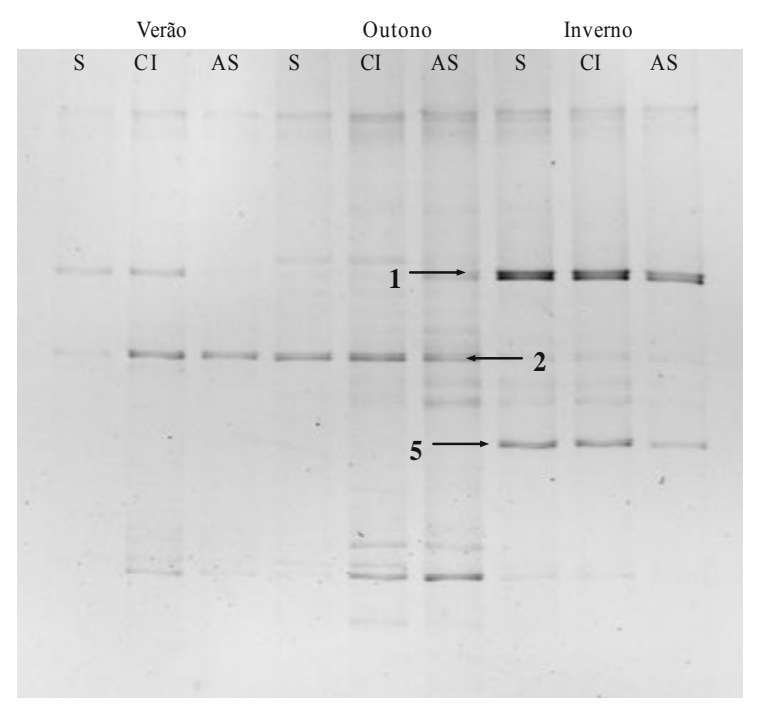

(b)

Figura 5.60: Gel de DGGE (gradiente 20\%-60\%) das variações sazonais na lagoa anaeróbia com primers para as BRS, referente aos horários: T1(a) e T3(b).

$\mathrm{S}=$ sub-superfície, $\mathrm{CI}=$ camada intermediária, $\mathrm{AS}=$ interface água-sedimento 


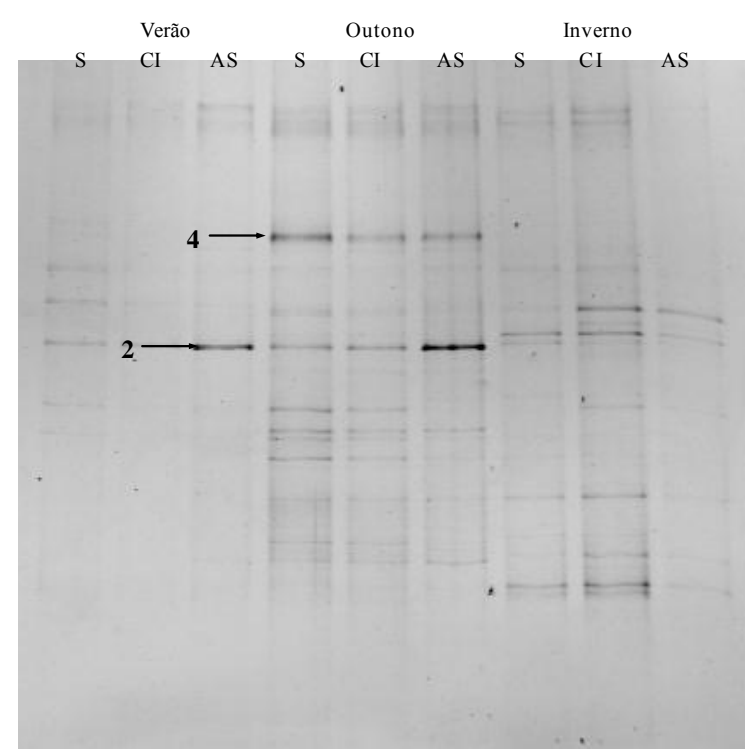

(a)

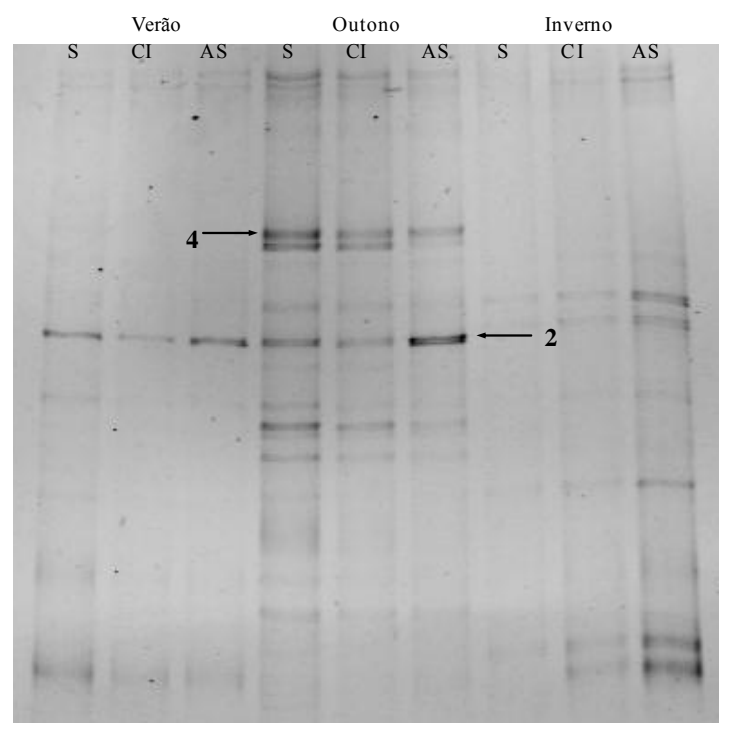

(b)

Figura 5.61: Gel de DGGE (gradiente 20\%-60\%) das variações sazonais na lagoa facultativa com primers para as BRS, referente aos horários: T1(a) e T3(b).

$\mathrm{S}=$ sub-superfície, $\mathrm{CI}$ = camada intermediária, $\mathrm{AS}=$ interface água-sedimento

A Tabela 5.12 mostra as informações das seqüências das BRS verificadas nas lagoas anaeróbia e facultativa nas diferentes épocas do ano e pontos de coleta.

Tabela 5.12: Informação das seqüências com primers para as BRS obtidas das bandas recortadas do DGGE das lagoas anaeróbia e facultativa

\begin{tabular}{|c|c|c|c|c|}
\hline Banda & Microrganismo & \# acesso & $\begin{array}{c}\text { Similaridade } \\
\%\end{array}$ & Referência \\
\hline Banda 1 & $\begin{array}{l}\beta \text {-proteobactéria não } \\
\text { cultivada }\end{array}$ & AY947965.1 & 91 & $\begin{array}{l}\text { Crump (2005). Não } \\
\text { publicado (Gen BanK) }\end{array}$ \\
\hline Banda 2 & Bactéria não cultivada & AM181927.1 & 93 & $\begin{array}{l}\text { Schwarz (2006). Não } \\
\text { publicado (Gen BanK) }\end{array}$ \\
\hline Banda 3 & Bactéria não cultivada & AY212671 & 96 & Simpson (2004) \\
\hline Banda 4 & Proteobactéria não cultivada & DQ450169.1 & 95 & $\begin{array}{l}\text { Piccini (2006). Não } \\
\text { publicado (Gen BanK) }\end{array}$ \\
\hline Banda 5 & $\begin{array}{l}\delta \text {-proteobactéria não } \\
\text { cultivada }\end{array}$ & AY711321.1 & 96 & $\begin{array}{l}\text { Moran (2004). Não } \\
\text { publicado (Gen BanK) }\end{array}$ \\
\hline
\end{tabular}


A seqüência referente à banda 1 ( $\beta$-proteobactéria não cultivada), com similaridade de $91 \%$, foi verificada nas diferentes profundidades na lagoa anaeróbia, no inverno, para os dois horários de coleta. $\mathrm{O}$ pH variou de 8,0 na interface água-sedimento, a 9,4 na subsuperfície. A temperatura variou de $19,6^{\circ} \mathrm{C}$ na camada intermediária e interface águasedimento, a $26,9^{\circ} \mathrm{C}$ na sub-superfície. $\mathrm{O}$ oxigênio dissolvido variou de $0,14 \mathrm{mg} / \mathrm{L}$ na interface água-sedimento, a $8,2 \mathrm{mg} / \mathrm{L}$ na sub-superfície. Constitui uma bactéria considerada esporádica na lagoa anaeróbia. Foi identificada como constituinte do grupo $\beta$ proteobactéria, em estudo da sincronia e sazonalidade de comunidades do bacterioplâncton em dois rios temperados (CRUMP et al., 2005).

A seqüência referente à banda 2 (Bactéria não cultivada), com similaridade de $93 \%$, foi verificada em ambas as lagoas nos dois horários de coleta. Na lagoa anaeróbia, no horário $\mathrm{T} 1$, foi observada na sub-superfície, camada intermediária e interface águasedimento, no verão e outono. No horário T3, foi verificada na camada intermediária e na interface água-sedimento, no verão; e nas diferentes profundidades, no outono. Na lagoa facultativa, no horário T1, foi observada na interface água-sedimento, no verão; e na subsuperfície, camada intermediária e interface água-sedimento, no outono. No horário T3, foi verificada nos três pontos de coleta no verão e outono. Nesses períodos o valor de $\mathrm{pH}$ variou de 7,0 na camada intermediária, a 11,3 na sub-superfície. A temperatura variou de $25,2^{\circ} \mathrm{C}$ na interface água-sedimento, a $35,1^{\circ} \mathrm{C}$ na sub-superfície. $\mathrm{O}$ oxigênio dissolvido variou de $0,0 \mathrm{mg} / \mathrm{L}$ na camada intermediária e interface água-sedimento, a 8,2 mg/L na subsuperfície. Esse microrganismo foi favorecido por essas diferentes condições ambientais verificadas nas duas lagoas. A bactéria foi identificada a partir de amostra natural, em estudo sobre a identificação das comunidades microbianas no sedimento do lago Kinneret (Israel) (SCHWARZ et al., 2006).

A seqüência referente à banda 3 (Bactéria não cultivada), com similaridade de $96 \%$, foi observada na camada intermediária e interface água-sedimento da lagoa anaeróbia, no outono (14:00 h, T1). $\mathrm{O} \mathrm{pH}$ na camada intermediária foi de 7,1 ; temperatura de $26,5^{\circ} \mathrm{C}$ e oxigênio dissolvido de $0,0 \mathrm{mg} / \mathrm{L}$. O pH na interface água-sedimento foi de 7,0; temperatura de $26,2^{\circ} \mathrm{C}$, e oxigênio dissolvido de $0,0 \mathrm{mg} / \mathrm{L}$. Possivelmente represente uma bactéria eventual na lagoa anaeróbia, e foi identificada em estudo sobre contaminação fecal eqüina (SIMPSON et al., 2004). 
A seqüência referente à banda 4 (Proteobactéria não cultivada), com similaridade de $95 \%$, foi observada em ambas as lagoas nos dois horários de coleta. Na lagoa anaeróbia, no horario T1, foi verificada na sub-superfície, no outono. Na lagoa facultativa, em ambos os horários de coleta, foi observada nas diferentes profundidades, também no outono. $\mathrm{O} \mathrm{pH}$ variou de 7,4 na interface água-sedimento, a 10,0 na sub-superfície. A temperatura variou de $26,5^{\circ} \mathrm{C}$ na interface água-sedimento, a $34,3^{\circ} \mathrm{C}$ na sub-superfície. $\mathrm{O}$ oxigênio dissolvido variou de $0,03 \mathrm{mg} / \mathrm{L}$ na interface água-sedimento, a 7,2 $\mathrm{mg} / \mathrm{L}$ na sub-superfície. Foi verificada em estudo da composição do bacterioplâncton em lagoa da costa atlântica do Uruguai, e identificada como pertencente ao grupo proteobactéria (PICCINI et al., 2006).

A seqüência referente à banda 5 ( $\delta$-proteobactéria não cultivada), com similaridade de $96 \%$, foi verificada nas diferentes profundidades da lagoa facultativa, no inverno, no horário T3 $(02: 00$ h). Sob tais condições, o valor de $\mathrm{pH}$ variou de 7,8 na interface águasedimento, a 10,2 na sub-superfície. A temperatura variou de $19,6^{\circ} \mathrm{C}$ na interface águasedimento, a $20,8^{\circ} \mathrm{C}$ na sub-superfície. A bactéria é pertencente ao grupo $\delta$-proteobactéria e foi identificada em estudo sobre a diversidade de espécies de bactérias de um ambiente pantanoso (MORAN et al., 2004).

A Figura 5.62 mostra a árvore filogenética de consenso proveniente da informação de seqüências obtidas das lagoas de estabilização.

$\mathrm{Na}$ realização da árvore foram acrescentadas seqüências conhecidas de Desulfovibrio vulgaris (AB294142) e de Desulfotomaculum ruminis (AB294140). 


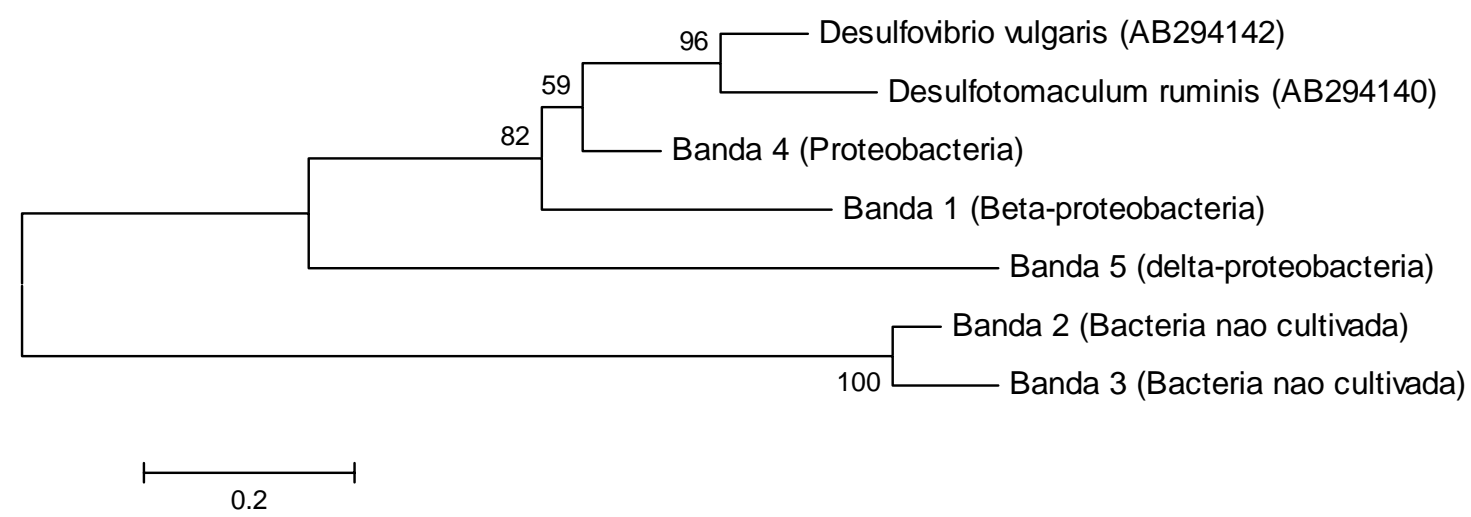

Figura 5.62: Árvore filogenética de consenso baseada nas seqüências das bandas recortadas do DGGE com primers para as bactérias redutoras de sulfato, obtidas das lagoas anaeróbia e facultativa. Os valores presentes nos nós das árvores indicam porcentagens que o ramo se repitiu (500 reamostragens de bootstraps) 


\subsection{Purificação de Bactéria Fototrófica Púrpura}

Foi realizada a transferência de amostras dos diferentes pontos de coleta, de ambas as lagoas, separadamente, para meio de cultura anaeróbio. Após um período de 18 dias, todos os frascos apresentaram coloração ligeiramente amarela, indicando crescimento celular (Figura 5.63). Novamente, procedeu-se a transferência desse material para as mesmas condições nutricionais e 1.541,6 mg/L de acetato de amônia (Figura 5.64). Após um período de 10 dias, foram observadas colorações vermelhas, principalmente nos frascos com amostras da superfície da lagoa anaeróbia, realizando-se um novo repique nas mesmas condições nutricionais.

Após 10 dias de crescimento bacteriano, foi realizada a diluição seriada (Figura 5.65), nas mesmas condições nutricionais, com amostras que apresentaram crescimento de bactérias fototróficas púrpuras. As culturas apresentaram coloração avermelhada após 4 dias de incubação. Finalmente, foi realizada a purificação da colônia de bactéria púrpura, em roll-tube, utilizando amostra (da diluição seriada $10^{-4}$ ) proveniente da sub-superfície da lagoa anaeróbia, da coleta realizada na primavera (outubro de 2004). Esse crescimento foi observado após 5 dias de incubação.

As amostras que apresentaram crescimento bacteriano (turvação do meio) nas diferentes épocas do ano são mostradas na Tabela 5.13.

Tabela 5.13: Crescimento de bactérias fototróficas púrpuras

\begin{tabular}{|c|c|c|c|c|c|c|c|c|}
\hline \multirow[t]{2}{*}{ Pontos de coleta } & \multicolumn{4}{|c|}{ Lagoa anaeróbia } & \multicolumn{4}{|c|}{ Lagoa facultativa } \\
\hline & Primavera & Verão & Outono & Inverno & Primavera & Verão & Outono & Inverno \\
\hline Afluente & $\mathrm{X}$ & $\mathrm{X}$ & $\mathrm{X}$ & - & - & - & - & - \\
\hline $\begin{array}{l}\text { Sub- } \\
\text { superfície }\end{array}$ & $\mathrm{X}$ & $\mathrm{X}$ & $\mathrm{X}$ & $\mathrm{X}$ & - & $\mathrm{X}$ & - & $\mathrm{X}$ \\
\hline $\begin{array}{l}\text { Camada } \\
\text { intermediária }\end{array}$ & $\mathrm{X}$ & - & - & - & - & - & - & - \\
\hline $\begin{array}{l}\text { Interface } \\
\text { água- } \\
\text { sedimento }\end{array}$ & - & - & - & - & $X$ & - & - & - \\
\hline Efluente & $\mathrm{X}$ & - & - & - & - & - & - & - \\
\hline
\end{tabular}

$\mathrm{X}=$ frascos que apresentaram turvação do meio

- = frascos que não apresentaram turvação do meio 


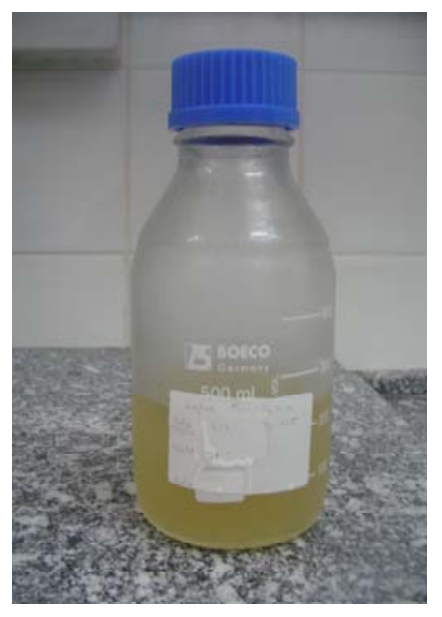

Figura 5.63: Frasco contendo crescimento de bactérias em suspensão com inóculo proveniente da lagoa anaeróbia

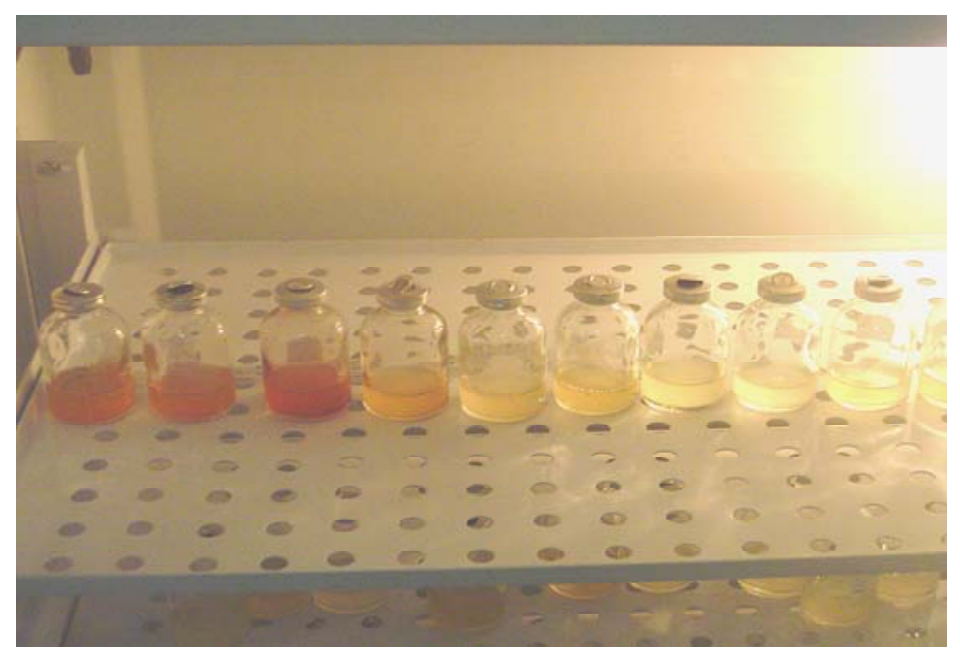

Figura 5.64: Frascos apresentando crescimento de bactérias fototróficas púrpuras incubadas a $30 \pm 2^{0} \mathrm{C}$ e $4000-5000$ lux de intensidade luminosa 


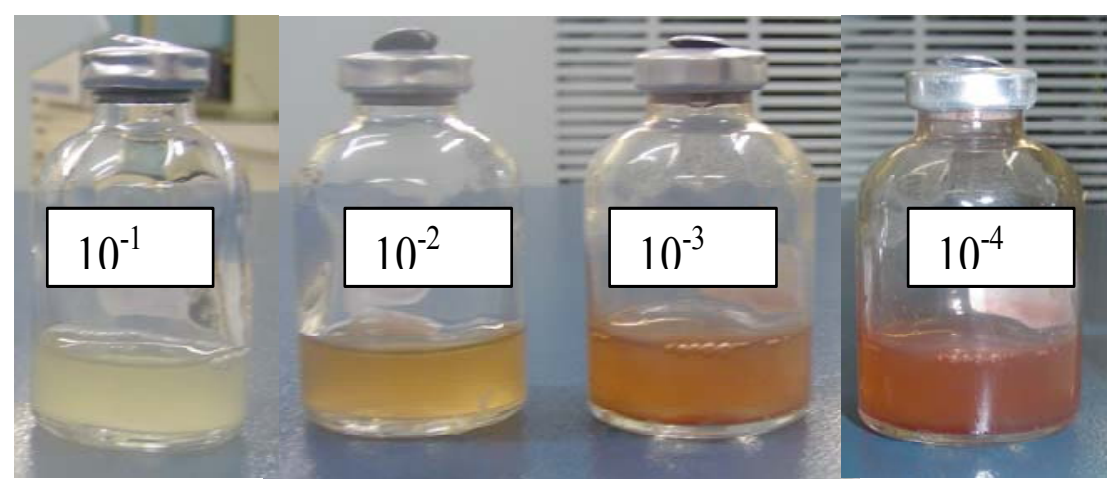

Figura 5.65: Diluição seriada em meio líquido de cultura de bactérias fototróficas púrpuras

A morfologia predominante observada em todas as etapas de purificação celular das amostras provenientes das lagoas anaeróbia e facultativa foi caracterizada por células semelhantes a bacilos curvos (Figura 5.66). Tais células, visualmente, apresentavam, inicialmente, coloração alaranjada e, tornavam-se avermelhadas em função do crescimento celular. Sob microscopia de luz comum, os bacilos apresentaram, também, coloração avermelhada.

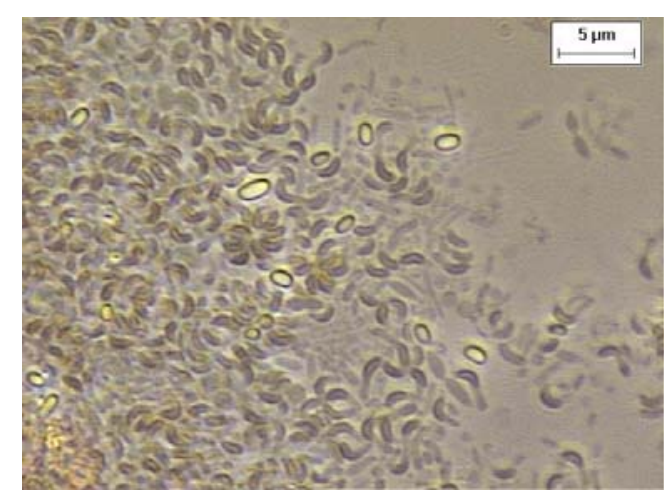

Figura 5.66: Microscopia de contraste de fase de bacilos curvos semelhantes a bactéria fototrófica púrpura, em etapa de purificação (Obj. 1000X) 
Em meio sólido (roll-tube) foram observadas colônias circulares, gelatinosas, púrpuras e com bordas lisas, as quais desenvolveram-se completamente após 20 dias de incubação a $30 \pm 1{ }^{0} \mathrm{C}$ (Figura 5.67). Na Tabela 5.14 estão descritos os números e tamanhos das colônias observadas em meio sólido.

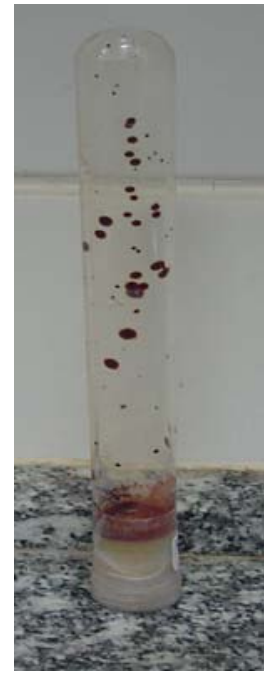

(a)

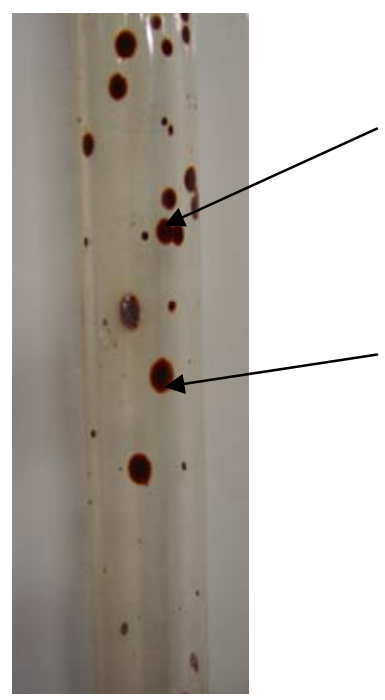

(b)

Figura 5.67: Colônias de bactérias fototróficas púrpuras: (a) aspecto geral do roll-tube, (b) Colônias avermelhadas

Tabela 5.14: Caracterização morfológica das colônias no roll-tube

\begin{tabular}{l|c|c}
\hline \multicolumn{1}{c|}{ Colônias } & Tamanho & Quantidade \\
\hline Grandes & $3 \mathrm{~mm}$ & 10 \\
Medianas & $2 \mathrm{~mm}$ & 13 \\
Pequenas & $0,5-1,0 \mathrm{~mm}$ & 32 \\
\hline
\end{tabular}


As células obtidas nas colônias do roll-tube foram submetidas à coloração diferencial de Gram. Tais células apresentaram, sob microscopia óptica de luz comum, coloração vermelha, indicando bacilos curvos Gram negativos (Figura 5.68).

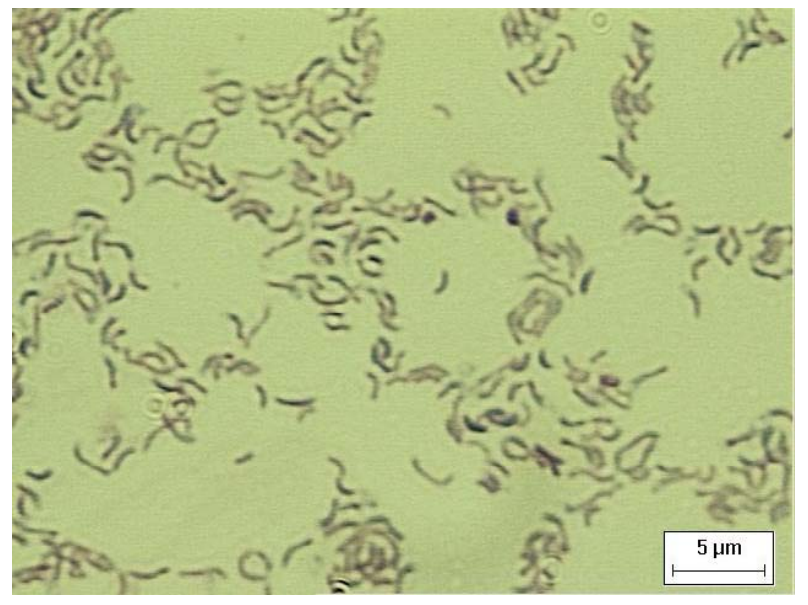

Figura 5.68: Microscopia óptica de luz de bacilos curvos Gram negativos, semelhantes a bactéria fototrófica púrpura (Obj. 1000X)

Seqüências obtidas a partir da cultura em etapa de purificação de bactéria fototrófica anoxigênica proveniente da sub-superfície da lagoa anaeróbia, utilizando os primers $1392 \mathrm{R}$ e 968F (Domínio Bacteria), foram 99\% similares a Clostridium sp. A mesma amostra, utilizando primers pufM.750R e pufM.557F (do centro fotossintético das bactérias fototróficas púrpuras), foram $92 \%$ similares a Rhodopseudomonas palustris.

Uma variedade de substratos orgânicos são fotoassimilados, inclusive muitos intermediários do ciclo dos ácidos tricarboxílicos, açúcares, aminoácidos, lactato, glicerol e butirato, porém não utilizam álcool, tartarato e formiato. A faixa ótima de $\mathrm{pH}$ varia entre 6,5 a 7,5 , e a temperatura entre $30^{\circ} \mathrm{C}$ a $35^{\circ} \mathrm{C}$. Os fatores de crescimento requeridos são tiamina e ácido nicotínico, embora extrato de levedura e biotina também favoreçam o crescimento de tais células. Em crescimento fotolitotrófico, utilizam hidrogênio molecular e gás carbônico. Sulfito e tiossulfato não podem ser usados como doadores de elétrons (ERICKSON, 1980). 
Os membros da Família Rhodospirillaceae são capazes de crescer fototroficamente ou autotroficamente. Particularmente, desenvolvem estratégias fisiológicas que lhes permitem crescer no escuro. A maioria desses representantes cresce em meio mineral contendo ácidos orgânicos ou ácidos graxos, como fontes de carbono e amônia como fonte de nitrogênio. Crescimento fotossintético com substâncias orgânicas como fontes de carbono, é referido como crescimento fotoheterotrófico. Muitos desses compostos orgânicos usados fotossinteticamente podem servir como fontes de energia e de carbono para a respiração heterotrófica no escuro (MADIGAN et al., 2006). Na presente pesquisa foram adicionados ao meio de cultura utilizado na purificação de bactéria fototrófica púrpura, 1.541,6 mg/L de acetato de amônia e 10,0 g/L de extrato de levedura, e intensidade luminosa de 4.000-5.000 lux que favoreceram crescimento desse microrganismo. 


\section{CONCLUSÕES}

$\sqrt{ }$ No outono, foi verificada nas lagoas maior diversidade do Domínio Bacteria, grupo das bactérias fototróficas púrpuras e das bactérias redutoras de sulfato; e na primavera foram verificadas menores diversidades desses microrganismos estudados. No outono, os valores de $\mathrm{pH}$ e temperatura foram menores e maiores aos das outras épocas do ano, respectivamente, os quais possivelmente, favoreceram a maior diversidade de bactérias.

$\sqrt{ } \mathrm{Na}$ lagoa anaeróbia, na sub-superfície, no verão e outono, sob intensidades luminosas similares, foram verificadas populações semelhantes de microrganismos pertencentes ao Domínio Bacteria. Valores similares de oxigênio dissolvido favoreceram a presença de populações semelhantes na camada intermediária e interface água sedimento nessas épocas do ano.

$\sqrt{ } \mathrm{Na}$ lagoa facultativa foi observada uma maior diversidade do Domínio Bacteria e das bactérias redutoras de sulfato quando comparada com a da lagoa anaeróbia.

$\sqrt{ }$ Maior número de populações de microrganismos foi verificado no período diurno nas diferentes épocas do ano, sugerindo maior presença dos microrganismos nesse período. $\mathrm{Na}$ coleta realizada no horário T3 foi observada a diminuição do número de populações no inverno e a manutenção deste no verão e outono, em relação à coleta do horário T1 . 
$\sqrt{ }$ Maior diversidade de bactérias fototróficas púrpuras foi observada no outono, favorecido possivelmente pelos valores de $\mathrm{pH}$ e temperatura, ótimos para o desenvolvimento desses microrganismos, verificados nas lagoas nessa época do ano.

$\sqrt{ }$ Duas populações de bactérias fototróficas púrpuras predominantes foram observadas na lagoa anaeróbia nas quatro estações do ano, independente dos horários de coletas (período diurno ou noturno), dos parâmetros físico-químicos, e dos pontos de amostragem.

$\sqrt{ }$ As concentrações de oxigênio dissolvido encontradas na lagoa facultativa, no outono, foram superiores às verificadas na lagoa anaeróbia. Possivelmente, as menores concentrações de oxigênio dissolvido observadas na lagoa anaeróbia, favoreceram o crescimento de bactérias fototróficas nessa época do ano, com aparecimento de maior número de bandas no perfil de DGGE quando comparado com as outras épocas do ano.

$\sqrt{ }$ As condições nutricionais observadas nas lagoas de estabilização favoreceram o desenvolvimento de microrganismos anaeróbios, anaeróbios facultativos, microaerófilos e aeróbios. Com relação à temperatura, favoreceram o desenvolvimento de microrganismos psicrofílicos no inverno, e mesofílicos nas outras épocas do ano. As variações dos valores de $\mathrm{pH}$ observadas nas lagoas sugerem a presença de microrganismos neutrófilos e alcalófilos.

$\sqrt{ } \mathrm{Na}$ lagoa anaeróbia, nas coletas realizadas no outono e verão, onde foram observadas maiores diversidades das bactérias redutoras de sulfato, foram verificadas as maiores porcentagens de remoção de sulfato, com $100 \%$ e $79,6 \%$, respectivamente, possivelmente realizada por esse grupo específico de microrganismos ou por outras bactérias, no metabolismo assimilativo.

$\sqrt{ } \mathrm{Na}$ lagoa anaeróbia, no outono, foram verificadas maiores remoções de sulfato e de sólidos suspensos voláteis $(100 \%)$. Na primavera foi verificada a maior remoção da matéria orgânica bruta $\left(\mathrm{DQO}_{\mathrm{b}}\right)(65,9 \%)$. A remoção de 51,8\% de NTK foi observada no outono, e a de PT (78,7\%), na primavera. As menores porcentagens de redução de NTK e PT foram observadas no verão, quando a temperatura variou de $26,2^{\circ} \mathrm{C}$ a $27,0^{\circ} \mathrm{C}$, respectivamente. 
$\sqrt{ } \mathrm{Na}$ lagoa facultativa as maiores remoções de sulfato, matéria orgânica e fósforo total foram verificadas, no outono. Consequentemente maior diversidade dos diferentes microrganismos estudados ocorreu no período dessa maior remoção dos parâmetros físicoquímicos.

$\sqrt{ } \mathrm{O}$ crescimento de bactérias fototróficas púrpuras foi verificado em meio enriquecido, de amostras provenientes das lagoas anaeróbia e facultativa. Bacilo curvo Gram negativo semelhante à bactéria fototrófica púrpura não sulfurosa foi purificado de amostra proveniente da sub-superfície da lagoa anaeróbia.

$\sqrt{ }$ Mediante seqüenciamento parcial de amostra proveniente da purificação celular, foram identificados Clostridium sp. (98\% de similaridade) e Rhodopseudomonas palustris (92\% de similaridade).

$\sqrt{ }$ Os microrganismos identificados, pertencentes ao Domínio Bacteria foram os seguintes: (Bactéria não cultivada, AY955092), (Bactéria não cultivada, AF429247.1), (Gamaproteobactéria não cultivada, AY664240.1), (Thauera sp., DQ851177.1), (Chromobacterium suttsuga, AY344056.1), (Clostridium sp., AF443594), (Protobactéria não cultivada, AY664120.1), (Rhodobacter sphaeroides, CP000143), (Rhodopseudomonas palustris, CP000301), (Lampropedia hyalina, AY291119), (Bacteroidetes não cultivado, AY274849.1), (Bactéria não cultivada, DQ520192.1), (Campylobacter fetus subsp. fetus, CP000487.1), (Bactéria não cultivada, AF428649.1), (Beta-proteobactéria não cultivada, DQ861922), e (Desulfovibrio vulgaris subsp. vulgaris, AE017285.1).

$\sqrt{ }$ Os microrganismos identificados com utilização dos primers puf $\mathrm{M}$ foram os seguintes: (Chromatium vinosum, ABO11811.1), (Roseobacter sp. BS90, AY675565.1), (Bactéria não cultivada, AM162697.1), (Bactéria não cultivada, AY044247.1), (Thiocapsa sp., AJ544223.2), (Bactéria não cultivada, AM162737.1), (Bactéria não cultivada, DQ080988.1), (Rhodospirillum rubrum, AY390602.1), (Bactéria não cultivada, AY044246.1), (Chromatium sp., D50647.1), (Roseobacter sp. SO3, AY675566.1), e (Rhodopseudomonas palustris, AB015977.1). 


\section{RECOMENDAÇÕES}

$\sqrt{ }$ Avaliar a diversidade no sedimento da lagoa, utilizando primers para o Domínio Bacteria, Domínio Archaea e para bactérias fototróficas anoxigênicas.

$\sqrt{ }$ Avaliar o potencial redox nas diferentes profundidades das lagoas de estabilização, com a finalidade de relacioná-los com a presença ou ausência de grupos específicos de microrganismos.

$\sqrt{ }$ Determinar as concentrações de sulfeto na lagoa anaeróbia, com intuito de relacionálas com a presença de grupos específicos de microrganismos, tais como bactérias fototróficas anoxigênicas sulfurosas ou bactérias redutoras de sulfato.

$\sqrt{ }$ Isolar os diferentes microrganismos responsáveis pela degradação da matéria orgânica nas lagoas de estabilização, com intuito de propor a utilização dos mesmos em processos biotecnológicos de tratamento de águas residuárias.

$\sqrt{ }$ Realização da clonagem a partir de amostras mistas provenientes das lagoas de estabilização utilizando primers universais para o Domínio Bacteria ou para grupos específicos, e posterior seqüenciamento para identificação e análise de filogenia. 80 


\section{REFERÊNCIAS BIBLIOGRÁFICAS}

ACHENBACH, L. A; CAREY, J.; MADIGAN, M. T. (2001). Photosynthetic and Phylogenetic primers for detection of Anoxygenic Phototrophs in Natural Environments. Applied and Environmental Microbiology, v.67, n.7, p. 2922-2926, jul.

AMANN R.I, LUDWING W, SCHLEIFER K.H. (1995). Phylogenetic identification and in situ detection of individual microbial cells without cultivation. Microbiological Reviews. 59:143-69.

ANDRADE NETO, C.O. (1997). Sistemas simples para tratamento de esgotos sanitários: experiência brasileira. ABES - Associação Brasileira de Engenharia Sanitária e Ambiental. Rio de Janeiro, RJ. 299p.

APHA; AWWA; WPCF (1998). Standard Methods for the Examination of Water and Wastewater. 20 ed. Washington, D. C.

BARBOSA, G.; ARAÚJO, V.; SILVA, J.; SOUSA, J. (2000). Estudo de espécies de fósforo em lagoas de estabilização. XXVII Congresso Interamericano de Engenharia Sanitária e Ambiental. Brasil.

BEJA, O.; SUZUKI, M.; HEIDELBERG, J. (2002). Unsuspected Diversity among Marine Aerobic Anoxygenic Phototrophs. Letters to Nature, 415: 630-633.

BRITSCHGI, T.; GIOVANNONI, S. (1991). Phylogenetic analysis of a natural marine bacterioplankton population by rRNA gene cloning and sequencing. Applied and Environmental Microbiology, v.57, n.6, p.1707-1713, jul.

CALIJURI, et al (2002). Estudo dos sistemas redutores de cargas naturais e artificiais para a Sustentabilidade dos Recursos Hídricos do Baixo Ribeira de Iguape - SP - Projeto Temático. Escola de Engenharia de São Carlos, Universidade de São Paulo. 
CAMATTA, M.E.; SILVEIRA, I.A.; RAMALDES, D.L. (2002). Lagoa anaeróbia com coloração rosa: estudo de caso. In: VI Simpósio Ítalo Brasileiro de Engenharia Sanitária e Ambiental, Vitória, 1-5 set. 2002.

CANHOS, V.P.; VAZOLLER, R.F. (1999). Biodiversidade do Estado de São Paulo: Microrganismos e vírus. São Paulo: FAPESP.

CASAMAYOR, E.; SCHAFER, H.; BAÑERAS, L.; PEDRÓS-ALIÓ, C.; MUYZER, G. (2000). Identification of and spatio-temporal differences between microbial assemblages from two neighboring sulfurous lakes: comparison by microscopy and denaturing gradient gel electrophoresis. Appl. Env. Microb., v.66, n.2, p.499-508, feb.

DÍEZ, B.; PEDRÓS-ALIÓ, C.; MARSH, T. L.; MASSANA, R. (2001). Application of Denaturing Gradient Gel Electrophoresis (DGGE) To Study the Diversity of Marine Picoeukaryotic Assemblages and Comparison of DGGE with Other Molecular Techniques. Appl. Env. Microb., v.67, n.7, p.2942-2951, jul.

DSM-Scientific Services of Culture Collections. Curso Ministrado na Fundação Tropical de Pesquisas e Tecnologia “André Tosello”, Campinas, 1991.

ERICKSON, L. E., (1980). Growth and Product Energetic Yields of Rhodopseudomonas sphaeroides S in Dark and Aerobic Chemostat Cultures. J. Ferment, Tecnnol., v.58, n.1, p.53-59.

ESTEVES, F.A. (1998). Fundamentos de limnologia. Interciência. Rio de Janeiro. 2ed. $602 p$.

FALCO, P.B. (2005). Estrutura da comunidade microbiana (algas e bactérias) em um sistema de lagoas de estabilização em duas escalas temporais: nictemeral e sazonal. São Carlos. 137p. Tese (Doutorado) - Escola de Engenharia de São Carlos, Universidade de São Paulo, São Carlos. 2005. 
FERNÁNDEZ, A.; TEJEDOR, C.; CHORDI, A. (1992). Influence of pH on the elimination of fecal coliform bacteria in waste stabilization ponds. Water, Air, and Soil Pollution, n.63, p.317-320.

FERRIS, M. J.; MUYZER, G.; WARD, D. (1997). Denaturing gradient gel electrophoresis profiles of $16 \mathrm{~S}$ rRNA-defined populations inhabiting a hot spring microbial mat community. Applied and Environmental Microbiology, v.62, n.2, p.40-346, feb.

FIORINI, M.P. (2004). Mudanças temporais da comunidade fitoplanctônica e das condições ecológicas de efluente final da ETE do Município de Cajati, SP. São Carlos. 106p. Dissertação (Mestrado) - Escola de Engenharia de São Carlos, Universidade de São Paulo, São Carlos. 2004.

GILLAN, D.; SPEKSNIJDER, A.; ZWART, G.; RIDDER, C. (1998). Genetic diversity of the biofilm covering Montacuta ferruginosa (Mollusca, Bivalvia) as evaluated by denaturing gradient gel electrophoresis analysis and cloning of PCR-Amplified gene fragments coding for 16S rRNA. Applied and Environmental Microbiology, v.64, n.9, p.3464-3472, sept.

GOMES, J.L. (2002). Estudo comparativo entre oito sistemas de lagoas de estabilização da região noroeste do Estado de São Paulo. São Carlos. 320p. Tese (Doutorado) - Escola de Engenharia de São Carlos, Universidade de São Paulo, São Carlos. 2002.

GRANADO, D.C (2004). Variações nictemerais e sazonais na estrutura da comunidade fitoplanctônica num sistema de lagoas de estabilização (Novo Horizonte, SP). São Carlos. 130p. Dissertação (Mestrado) - Escola de Engenharia de São Carlos, Universidade de São Paulo, São Carlos. 2004.

GRIFFITHS R. I., WHITELEY A. S., O’DONNELL A. G., BAILEY M. J. (2000). Rapid method for coextraction of DNA and RNA from natural environments for analysis of 
ribosomal DNA and rRNA-based microbial community compositon. Appl. Environ. Microbiol. ,v.66: 5488-5491.

HEIDELBERG, ET AL. (2004). The genome sequence of the anaerobic, sulfate-reducing bacterium Desulfovibrio vulgaris Hildenborough. Nat. Biotechnol., v.2, n.5, p.554-559.

HIRAISHI, A.; UEDA, Y. (1995). Isolation and characterization of Rhodovulum strictum sp. nov. and some other purple nonsulfur bacteria from colored blooms in Tidal and seawater pools. International Journal of Systematic Bacteriology, v.45, n.2, p.319-326, apr.

HOSETTI, B.; PATIL, H. (1987). Performance of wastewater stabilization ponds at different depths. Water, Air, and Soil Pollution, n.34, p.191-198.

HU, X.; DAMIANOVIC, A.; RITZ, T.; SCHULTEN, K. (1998). Architecture and mechanism of the light-harvesting apparatus of purple bacteria. Proc. Nat. Acad. Sci., v.95, p.5935-5941.

IBGE - INSTITUTO BRASILEIRO DE GEOGRAFIA E ESTATÍSTICA (2003). Tabelas das estimativas das populações residentes. Disponível em www.Ibge.gov.br.

IMHOFF, J.F.; CAUMETTE, P. (2004). Recommended standards for the description of new species of anoxygenic phototrophic bacteria. International Journal of Systematic Bacteriology, n.54, p.1415-1421.

IZU, K.; NAKAJIMA, F.; YAMAMOTO, K.; KURISU, F. (2001). Aeration conditions affecting growth of purple nonsulfur bacteria in an organic wastewater treatment process. System. Appl. Microbiol., v.24, p.294-302.

JOHNSON, M.; ZHULIN, I.; GAPUZAN, M-E.; TAYLOR, B. (1997). Oxygen-dependent growth of the obligate anaerobe Desulfovibrio vulgaris Hildenborough. Journal of Bacteriology, v.179, n.17, p.5598-5601. 
KARR, E.; SATTLEY, W.M.; JUNG, D.O.; MADIGAN, M.T.; ACHENBACH, L. (2003). Remarkable Diversity of Phototrophic Purple Bacteria in a Permanently Frozen Antarctic Lake. Applied and Enviromental Microbiology, Aug. v.69, n.8, p.4910-4914.

KARR, E.; SATTLEY, W.M.;RICE, R.; JUNG, D.O.; MADIGAN, M.T.; ACHENBACH, L. (2005). Diversity and Distribution of Sulfate-Reducing Bacteria in Permanently Frozen Lake Fryxell, McMurdo Dry Valleys, Antartica. Applied and Enviromental Microbiology, Oct. v.71, n.10, p.6353-6359.

KAWASAKI, S.; ISHIKURA, J.; CHIBA, D.; NISHINO, T.; NIIMURA, Y. (1998). Purification and characterization of an $\mathrm{H}_{2} \mathrm{O}$-forming $\mathrm{NADH}$ oxidase from Clostridium aminovalericum: existence of an oxygen-detoxifying enzyme in an obligate anaerobic bacteria. Arch. Microbiol., n.181, p.324-330.

KAYOMBO, S.; MBWETTE, T.S.A.; MAYO, A.W.; KATIMA, J.H.Y.; JORGENSEN, S.E. (2002). Diurnal cycles of variation of physical-chemical parameters in waste stabilization ponds. Ecological Engineering; n.18, p.287-291.

KELLNER, E. (2000). Modelação matemática do comportamento térmico de lagoas de estabilização : a estratificação e seus efeitos. São Carlos. 136p. Tese (Doutorado) - Escola de Engenharia de São Carlos, Universidade de São Paulo, São Carlos. 2000.

KIRCHMAN, D.L., COTTRELL, M.T. (2003). Diversity and abundante of uncultured cytophaga-like bacteria in the Delaware estuary. Appl. Environ. Microbiol., v.69, n.11, p.6587-6596.

LAI, P.; LAM, P. (1997). Major pathways for nitrogen removal in waste water stabilization ponds. Water, Air, and Soil Pollution, n.94, p.125-136. 
LANTZ, P-G.; TJERNELD, F.; HAHN-HAGERDAL, B.; RADSTROM, P. (1996). Use of aqueous two-phase systems in sample preparation for polymerase chain reaction-based detection of microorganisms. Jounal of Chromatography, n.680, p.165-170.

LEE, N.; CELlAMARE, C.M.; BASTIANUTTI, C. (2004). Emended description of the species Lampropedia hyaline. Int. J. Syst. Evol. Microbiol., v.54, p.1709-1715. sep.

MADIGAN, M. T.; MARTINKO, J.M.; PARKER, J (2006). Brock Biology of microorganisms. 11 ed. Prentice Hall, Inc USA.

MAYO, A.; NOIKE, T. (1996). Effects of temperature and $\mathrm{pH}$ on the growth of heterotrophic bacteria in waste stabilization ponds. Water Research, v.30, n.2, p.447-455.

MARTÍNEZ-ALONSO, M.; BLEIJSWIJK, J.; GAJU, N.; MUYZER, G. (2005). Diversity of anoxygenic phototrophic sulfur bacteria in the microbial mats of the Ebro Delta: a combined morphological and molecular approach. FEMS Microbiology Ecology. v.52, p.339-350.

MENDONÇA, S.R. (2000). Lagunas de estabilización. In: Mendonça, S.R. (ed). Sistemas de lagunas de estabilización - como utilizar aguas residuales tratadas en sistemas de regadío. McGraw-Hill. Colômbia. 370p.

METCALF, EDDY. (2001). Wastewater engineering - treatment disposal reuse. 3ed. McGraw-Hill International Edition. 1334p.

MIR, J.; MARTÍNEZ-ALONSO, M.; CAUMETTE, P. (2002). Sulfide fluxes in a microbial mat from the Ebro Delta, Spain. Int. Microbiol. 5:133-138.

MORAES, E. M.; ADORNO, M. A. T.; ZAIAT, M. (2004). Desenvolvimento e validação de método para análise de ácidos orgânicos de cadeia curta por CG/FID. In: $10^{\circ}$ CONGRESSO LATINO-AMERICANO DE CROMATOGRAFIA E TÉCNICAS AFINS, 
18-22 de outubro, 2004, Campos do Jordão, Brasil. Editor Fernando M. Lanças-USP-IQSC, p.153.

MURRAY, A.; HOLliBAUGH, J.; ORREGO, C. (1996). Phylogenetic compositions of bacterioplankton from two California estuaries compared by denaturing gradient gel electrophoresis of 16S rDNA fragments. Applied and Environmental Microbiology, v.62, n.7, p.2676-2680, jul.

MUYZER, G.; WAAL, E. C.; UITTERLINDEN, G. (1993). Profiling of Complex Microbial Populations by Denaturing Gradient Gel Electrophoresis Analysis of Polymerase Chain Reaction-Amplified Genes Coding for 16S RNAr. App. Env. Micr., v.59, n.3, p.695700.

NAGASHIMA, K. V. (1998). Primary structure of genes encoding light-harvesting and reaction. Submetido: 15/Setembro/2003. University, Faculty of Science, Department of Biology, Minamiohsawa 1-1, Hachioji, Tokyo 192-03, Japan.

NAGASHIMA, K. V.; HIRAISHI, A.; SHIMADA, K. (1997). Horizontal transfer of genes coding for the photosynthetic reaction centers of purple bacteria. Journal of Molecular Evolution, v.45, p.131-136.

NAKAGAWA, T; SATO, S.; YAMAMOTO, Y.; FUKUI, M. (2002). Successive changes in community structure of an ethylbenzene-degrading sulfhate-reducing consortium. Water Research, v.36, p.2813-2823.

NG, W.J.; CHIN, K.K.; WONG, K.K. (1989). Biological treatment alternatives for piggery wastes. In: International Biossystems, v.2, cap.6. Florida.

NIELSEN, A.; LIU, W-T.; FILIPE, C.; GRADY, L.; MOLIN, S.; STAHL, A. (1999). Identification of a novel group of bacteria in sludge from a deteriorated biological 
phosphorus removal reactor. Applied and Environmental Microbiology, v.65, n.3, p.12511258 , mar.

OLIVEIRA, R.; SILVA, S.; ARAUJO, A.; SOARES, J. (1996). The performance of a pilot-scale series of ten ponds treating municipal sewage in northeast Brazil. Wat. Sci. Tech., n.7, p.57-61.

OZ, A.; SABEHI, G.; KOBLÍZEK, M. (2005). Roseobacter-like bacteria in red and mediterranean sea aerobic anoxygenic photosynthetic. App. Env. Micr., 71: 344-353.

PFENNIG, N.; TRUPER, H. G. (1989). Anoxygenic phototrophic bacteria In: Bergey's Manual of Systematic Bacteriology (Staley, M. P.; Bryant, M. P.; Pfennig, N.; Holt, J. G.; Eds.) v.3, p.1635-1709. Williams and Wilkins, Baltimore.

RAJBHANDARI, B.; ANNACHHATRE, A. (2004). Anaerobic ponds treatment of starch wastewater: case study in Thailand. Bioresource technology, v.95, p.135-143.

RANCHOU-PEYRUSE, A.; HERBERT, R.; CAUMETTE, P.; GUYONEAUD, R. (2006), Comparison of cultivation-dependent and molecular methods for studying the diversity of anoxygenic purple phototrophs in sediments of an eutrophic brackish lagoon. Environmental Microbiology, 8, 1590-1599.

SATOH, T.; HOSHINO, Y.; KITAMURA, H. (1976). Rhodopseudomonas sphaeroides forma sp. Denitrificans, a Denitrifying strain as a subspecies of Rhodopseudomonas sphaeroides. Arch. Microbiol., n.108, p.265-269.

SEKIGUCHI, H.; WATANABE, M.; NAKAHARA, T.; XU, B.; UCHIYAMA, H. (2002). Succession of bacterial community structure along the Changjiang River determined by denaturing gradient gel electrophoresis and clone library analysis. Applied and Environmental Microbiology, v.68, n.10, p.5142-5150, oct. 
SELIG, U.; HUBENER, T.; HEERKLOSS, R.; SCHUBERT, H. (2004). Vertical gradient of nutrients in two dimictic lakes - influence of phototrophic sulfur bacteria on nutrient balance. Aquatic Sciences, 66, p.247-256.

SHIEH, W.K.; MULCAHY, L.T. (1986). Experimental determination of intrinsic kinetic coefficients for biological wastewater treatment systems. Water Science Technology. v.18, p.1-10.

SILVA, S.P. (2004). Isolamento e caracterização de bactéria redutora de sulfato: ênfase na remoção de benzoato. São Carlos. 97p. Tese (Mestrado) - Escola de Engenharia de São Carlos, Universidade de São Paulo, São Carlos. 2004.

SIRIANUNTAPIBOON, S.; SRIKUL, M. (2006). Reducing red color intensity of seafood wastewater in facultative pond. Bioresource Technology; n.97, p.1612-1617.

VARESCHE, M.B. (1997). Estudo com bactérias fototróficas anoxigênicas: enriquecimento, isolamento, caracterização nutricional e cinética de crescimento. São Carlos. 363p. Tese (Doutorado) - Escola de Engenharia de São Carlos, Universidade de São Paulo, São Carlos. 1997.

van NIEL'S C.B. (1944). The culture general physiology, morphology and classification of the non-sulfur purple and brown bacteria. Bacteriological Rewievs, v.8, p.1-18.

von SPERLING, M. (1996). Lagoas de estabilizacao. Departamento de Engenharia Sanitaria e Ambiental. Universidade Federal de Minas Gerais. V.3., 140p. Brasil.

von SPERLING, M.; JORDÃO, E.; KATO, M.; SOBRINHO, P.; BASTOS, R. (2003). Lagoas de estabilização. In: GONÇALVES, R.F. (ed). Desinfecção de efluentes sanitários. Programa de pesquisa em saneamento básico - PROSAB/3. p.277-336. 
WIELAND, A.; KUHL, M.; MCGOWAN, L.; FOURÇANS, A. (2003), Microbial mats on the orkney islands revisited: Microenvironment and microbial community composition. Microbial Ecology, 46, 371-390.

YUTIN, N.; SUZUKI, M. T.; BEJA, O. (2000), Novel primers reveal a wider diversity among marine aerobic. Artigo não publicado, submetido: 01/Junho/2005.

ZEHNDER, A. J. B. (1988). Biology of Anaerobic Microorganisms. 1 ed. USA. 
ANEXOS 


\section{A.1. Ácidos orgânicos voláteis}

A extração dos ácidos orgânicos voláteis foi realizada utilizando o seguinte procedimento: para frasco apropriado foram transferidos 2,0 $\mathrm{mL}$ de amostra, 1,0 $\mathrm{g}$ de cloreto de sódio (P.A.), $100 \mu \mathrm{L}$ de solução de ácido sulfúrico $1 \mathrm{M}, 100 \mu \mathrm{L}$ de solução de ácido crotônico (padrão interno) e 0,60 $\mathrm{mL}$ de éter etílico purificado gelado. Os frascos foram fechados hermeticamente, submetidos à agitação em vórtex por 30 segundos, depois centrifugados a $3000 \mathrm{rpm}$, durante 1 minuto e mantidos em freezer até a injeção. Posteriormente, foi injetado $1,0 \mu \mathrm{L}$ da fase orgânica no cromatógrafo utilizando-se seringa resfriada em freezer. Nesta análise foi utilizado o cromatógrafo HP6890/FID (ionização de chama) e coluna HP INNOWAX, de $30 \mathrm{~m}$ x 0,25 $\mathrm{mm}$ x 0,25 mm de espessura de filme. $\mathrm{O}$ gás de arraste foi hidrogênio, com fluxo de $2 \mathrm{~mL} /$ minuto.

\section{A.2. Extração de DNA}

O procedimento realizado está descrito a seguir:

1. Centrifugar amostra da lagoa em tubos Falcon de $15 \mathrm{~mL}$ por 10 minutos, a 6000 rpm e temperatura de $4^{\circ} \mathrm{C}$;

2. Descartar o sobrenadante e lavar o precipitado com $5 \mathrm{~mL}$ de tampão PBS $1 \mathrm{X}$ (10 $\mathrm{mL}$ de PBS 10X + $90 \mathrm{~mL}$ de água destilada);

3. Centrifugar por 10 minutos, a $6000 \mathrm{rpm}$ e temperatura de $4^{\circ} \mathrm{C}$;

4. Descartar o sobrenadante;

5. Acrescentar ao precipitado (colocar os tubos no gelo): 0,5 g de Glass Beads (150$212 \mu \mathrm{m}), 1 \mathrm{~mL}$ de fenol tamponado (equilibrado com Tris), $1 \mathrm{~mL}$ de clorofórmio e $1 \mathrm{~mL}$ de PBS (1X);

6. Agitar no vórtex;

7. Fazer uma seqüência de extração de DNA para descobrir o melhor tempo de extração. Os tempos considerados foram os seguintes: 20, 40, 60, 80, 100 e 120 segundos. O melhor tempo de extração encontrado foi de sessenta segundos;

8. Centrifugar por 10 minutos, a $6000 \mathrm{rpm}$ e temperatura de $4^{\circ} \mathrm{C}$;

9. Transferir o sobrenadante $(<1 \mathrm{~mL})$ e colocar em um eppendorf; 
10. Acrescentar $1,0 \mathrm{~mL}$ de solução tamponada de fenol (até encher). Agitar no vórtex. Centrifugar por 10 minutos, a $10000 \mathrm{rpm}$ e temperatura de $4^{\circ} \mathrm{C}$. Repetir, se for necessário;

11. Transferir o sobrenadante para outro tubo. Colocar 1,0 mL de clorofórmio. Agitar no vórtex. Centrifugar por 10 minutos a $10000 \mathrm{rpm}$ e temperatura de $4^{\circ} \mathrm{C}$;

12. Repetir o passo anterior;

13. Transferir o sobrenadante para um novo eppendorf e guardar a $-20^{\circ} \mathrm{C}$.

\section{A.3. Eletroforese em gel de agarose}

O procedimento realizado é descrito a seguir:

1. Preparar a solução $1 \%$ de agarose e solução tampão TAE $1 X$;

2. Preparar a "bandeja", colando fita crepe nos lados;

3. Despejar o gel na "bandeja", em seguida, colocar o "pente" para formar as cavidades;

4. Esperar solidificar o gel;

5. Retirar o "pente" e a fita crepe;

6. Preparar a amostra no parafilme usando $5,0 \mu \mathrm{L}$ de produto de ácido nucléico ou produto do PCR com 2,0 $\mu \mathrm{L}$ de "loading dye";

7. Misturar bem a amostra com auxílio de uma micropipeta;

8. Transferir as amostras para as cavidades do gel;

9. Colocar a bandeja na câmara eletroforética submersa em tampão TAE 1X. No presente trabalho utilizou-se a câmara Pharmacia Biotech GNA 100 (com programação de $50 \mathrm{~V}$ constante, por 1 hora);

10. Com auxílio de uma espátula, transferir o gel para recipiente contendo brometo de etídio, e deixar por 10 minutos;

11. Imergir o gel em outro recipiente contendo água ultrapurificada, por 5 minutos;

12. Colocar na câmara de transiluminador UV (Stratagene - Eagle Eye II). 


\section{A.4. Eletroforese em gel de gradiente desnaturante}

O procedimento realizado está descrito a seguir:

1. Preparar a solução do gel na concentração desejada;

2. Preparar o "sanduíche" com o kit de placas de vidro e suporte;

3. Preparar os géis;

4. Transferir os géis (30\% e 70\%), simultaneamente, para o "sanduíche" de placas de vidro;

5. Colocar o pente;

6. Esperar que polimerizem os géis;

7. Preparar a câmara eletroforética, adicionando $140 \mathrm{~mL}$ de TAE $50 \mathrm{X}$ e completar para 7 L com água ultrapurificada;

8. Aquecer a solução até a temperatura de $65^{\circ} \mathrm{C}$ e então transferir o "sanduíche" para essa câmara;

9. Misturar $20,0 \mu \mathrm{L}$ da amostra com $4,0 \mu \mathrm{L}$ de "loading dye";

10. Transferir a mistura para os "poços" do gel;

11. Ligar a bomba de agitação e ligar o equipamento a $75 \mathrm{~V}$;

12. Utilizar tempo de corrida de 16 horas e temperatura de $65^{\circ} \mathrm{C}$;

13. Transferir o gel das placas de vidro para bandeja contendo solução de brometo de etídio, mantendo-a por 20 minutos;

14. Colocar o gel no "FluoImager", conectado ao computador;

15. Fazer a leitura no computador.

Na Tabela A1 encontra-se descrito procedimento para o preparo da solução do gel de gradiente desnaturante.

Tabela A1: Gradiente no DGGE

\begin{tabular}{l|ccccc}
\hline Concentração do gel DGGE (\%) & $\mathbf{2 0 \%}$ & $\mathbf{3 0 \%}$ & $\mathbf{6 0 \%}$ & $\mathbf{7 0 \%}$ & $\mathbf{8 0 \%}$ \\
\hline Acrilamida 40\% (mL) & 20 & 20 & 20 & 20 & 20 \\
Solução TAE 50X $(\mathrm{mL})$ & 2 & 2 & 2 & 2 & 2 \\
Formamida $(\mathrm{mL})$ & 8 & 12 & 24 & 28 & 32 \\
Uréia $(\mathrm{g})$ & 8,4 & 12,6 & 25,2 & 29,4 & 33,6 \\
\hline
\end{tabular}




\section{A.5. Clonagem}

O protocolo para preparação do "Minipreps" para a clonagem está descrito a seguir (segundo Manual TOPO TA):

1. Realizar PCR com primers para Domínio Bacteria (1392R e 968F) e para o centro fotossintético das bactérias fototróficas púrpuras (pufM.750R e pufM.557F);

2. Verificar o produto da amplificação do fragmento de interesse em gel de agarose $1 \%$;

3. Preparar o seguinte mix de reação para adição de adeninas (A) (Tabela A2) e incubar a $72^{\circ} \mathrm{C}$, por 15 minutos.

\begin{tabular}{l|c} 
Tabela A2: Mix para adição de adeninas \\
\hline Reagentes & Volume $(\mu \mathbf{L})$ \\
\hline DNA & 3,0 \\
Taq 1U & 0,5 \\
dATP 5mM & 1,0 \\
Tampão PCR (10x) & 0,5 \\
MgCl $_{2}$ & 0,2 \\
Total & 5,2 \\
\hline
\end{tabular}

4. Preparar, para reação de ligação, o seguinte mix descrito na Tabela A3, incubar por 30 minutos em temperatura ambiente $\left( \pm 23^{\circ} \mathrm{C}\right)$. Colocar os tubos no banho de gelo. Fazer a transformação imediatamente.

\begin{tabular}{l|c} 
Tabela A3: Reação de ligação \\
\hline Reagentes & Volume $(\mu \mathbf{L})$ \\
\hline Produto de PCR & 4 \\
Solução salina & 1 \\
Vetor Topo & 1 \\
Volume total & 6 \\
\hline
\end{tabular}

5. Transformação (realizar no fluxo):

a. adicionar 4,0 $\mu \mathrm{L}$ de "produto da ligação" junto com "células competentes" (E. coli DH $5 \alpha$ ) e misturar com a ponta da pipeta, sem usar a sucção;

b. incubar por 20 minutos no gelo; 
c. colocar a $42^{\circ} \mathrm{C}$ por 2 minutos sem agitação;

d. misturar $250 \mu \mathrm{L}$ do meio S.O.C do kit (aquecido previamente a $42^{\circ} \mathrm{C}$ em banhomaria) mais o material transformado no fluxo;

e. agitar por 30 minutos, mantendo a temperatura de $37^{\circ} \mathrm{C}$.

6. Preparar as placas contendo meio LB sólido, adicionando os reagentes da Tabela A4.

Tabela A4: Placas com meio LB sólido

\begin{tabular}{l|c}
\hline Reagentes & Volume \\
\hline Meio LB & $50 \mathrm{~mL}$ \\
Xgal & $64 \mu \mathrm{L}$ \\
IPTG & $80 \mu \mathrm{L}$ \\
Ampicilina $(80 \mathrm{mg} / \mathrm{mL})$ & $30 \mu \mathrm{L}$ \\
\hline
\end{tabular}

7. Inoculação

a. Usar $50 \mu \mathrm{L}$ e $100 \mu \mathrm{L}$ do material transformado como inóculo;

b. Incubar as placas invertidas por \pm 24 horas, a $37^{\circ} \mathrm{C}$;

8. Pré-inoculação das colônias transformadas para extração do plasmídeo: inocular colônia transformada em meio LB líquido, sob agitação, a $37^{\circ} \mathrm{C}$ por \pm 16 horas;

9. Extração do plasmídeo:

1. Centrifugar $1,5 \mathrm{~mL}$ de cultura, durante 3 minutos, à temperatura ambiente;

2. Ressuspender em $100 \mu \mathrm{L}$ de GTE por 5 minutos, agitar no vórtex, à temperatura ambiente;

3. Adicionar $200 \mu \mathrm{L}$ de solução de $\mathrm{NaOH}$, agitar no vórtex e manter durante 5 minutos no gelo;

4. Adicionar $150 \mu \mathrm{L}$ de acetato de potássio, agitar no vórtex e manter durante 5 minutos no gelo;

5. Centrifugar a $1000 \mathrm{rpm}$ durante 5 minutos e transferir $400 \mu \mathrm{L}$ para novo tubo;

6. Adicionar $800 \mu \mathrm{L}$ de etanol $95 \%$. Manter por 2 minutos à temperatura ambiente. Centrifugar a $1000 \mathrm{rpm}$ durante 5 minutos e desprezar o sobrenadante; 
7. Ressuspender com $1,0 \mathrm{~mL}$ de etanol $75 \%$ e homogeneizar gentilmente . Centrifugar durante 5 minutos, desprezar o sobrenadante e deixar secar;

8. Ressuspender em $30 \mu \mathrm{L}$ de água ultrapurificada ou TE.

9. Verificar a extração do plasmídeo em gel de agarose $1 \%$. 10. Adicionar ao "pellet" $30 \mu \mathrm{L}$ de TE e 1,0 $\mu \mathrm{L}$ de RNAse $(10 \mathrm{mg} / \mathrm{L})$;

a. centrifugar a $4^{\circ} \mathrm{C}$, por 5 minutos;

b. transferir o sobrenadante para tubo estéril. 
Tabela B1: Dados obtidos na lagoa anaeróbia - Coleta na primavera (outubro 2004)

\begin{tabular}{|c|c|c|c|c|c|c|c|}
\hline $\begin{array}{c}\text { Locais de amostragem } \\
\text { (Cajati) }\end{array}$ & $\mathrm{pH}$ & $\begin{array}{c}\text { Temperatura } \\
\left({ }^{\circ} \mathrm{C}\right)\end{array}$ & $\begin{array}{c}\text { Oxigênio } \\
\text { dissolvido } \\
\text { (mg/L) }\end{array}$ & $\begin{array}{l}\text { Sulfato } \\
(\mathrm{mg} / \mathrm{L})\end{array}$ & $\begin{array}{l}\text { DQOf } \\
(\mathrm{mg} / \mathrm{L})\end{array}$ & $\begin{array}{l}\text { DQOb } \\
\text { (mg/L) }\end{array}$ & $\begin{array}{c}\text { SSV } \\
(\mathrm{mg} / \mathrm{L})\end{array}$ \\
\hline \multicolumn{8}{|l|}{ 19/10/2004 (08:00 h) } \\
\hline T0 afluente & 8,2 & 23,5 & 3,1 & 48 & 32 & 50 & 120 \\
\hline T0 sub-superfície & 9,6 & 23,4 & 0,7 & 3 & 71 & 196 & 193 \\
\hline T0 camada intermediária & 8,9 & 22,9 & 0,05 & 13 & 82 & 130 & 153 \\
\hline T0 interface água-sedimento & 8,9 & 22,9 & 0 & 13 & 122 & 298 & 190 \\
\hline T0 efluente & 9,1 & 22,9 & 0,3 & 20 & 25 & 122 & 213 \\
\hline \multicolumn{8}{|l|}{ 19/10/2004 (18:00 h) } \\
\hline $\mathrm{T} 2$ afluente & 8,8 & 23,5 & 0,5 & 63 & 20 & 255 & 93 \\
\hline T2 sub-superfície & 8,9 & 24,5 & 0,1 & 28 & 67 & 77 & 120 \\
\hline T2 camada intermediária & 8,9 & 23,4 & 0,04 & 23 & 95 & 120 & 86 \\
\hline $\mathrm{T} 2$ interface água-sedimento & 8,9 & 23,1 & 0,04 & 18 & 24 & 102 & 126 \\
\hline T2 efluente & 8,8 & 24 & 0,2 & 11 & 67 & 87 & 6 \\
\hline \multicolumn{8}{|l|}{ 20/10/2004 (02:00 h) } \\
\hline T3 afluente & 8,8 & 23,5 & 0,5 & & & 112 & \\
\hline T3 sub-superfície & 8,9 & 23,5 & 0,13 & & & 61 & \\
\hline T3 camada intermediária & 8,9 & 23,4 & 0,04 & & & 55 & \\
\hline T3 interface água-sedimento & 8,9 & 23,01 & 0,04 & & & 50 & \\
\hline \multicolumn{8}{|l|}{ 20/10/2004 (08:00 h) } \\
\hline T4 afluente & 8,9 & 23,5 & 0,3 & 49 & 81 & 185 & 170 \\
\hline T4 sub-superfície & 9 & 23,0 & 0,08 & 12 & 46 & 78 & 216 \\
\hline T4 camada intermediária & 8,9 & 23,0 & 0,04 & 19 & 49 & 96 & 203 \\
\hline T4 interface água-sedimento & 8,8 & 23,0 & 0,03 & 18 & 59 & 370 & 116 \\
\hline T4 efluente & 8,9 & 23,0 & 0,13 & 18 & 41 & 177 & 186 \\
\hline
\end{tabular}


Tabela B2: Nutrientes totais e dissolvidos na lagoa anaeróbia - Coleta na primavera (outubro 2004)

\begin{tabular}{|c|c|c|c|c|c|c|c|}
\hline \multirow[b]{2}{*}{$\begin{array}{c}\text { Locais de amostragem } \\
\text { (Cajati) }\end{array}$} & \multicolumn{5}{|c|}{ Nutrientes dissolvidos } & \multicolumn{2}{|c|}{ Nutrientes totais } \\
\hline & $\begin{array}{l}\text { Nitrato } \\
(\mathrm{mg} / \mathrm{L})\end{array}$ & $\begin{array}{l}\text { Nitrito } \\
(\mu \mathrm{g} / \mathrm{L})\end{array}$ & $\begin{array}{c}\text { Nitrogênio } \\
\text { amoniacal } \\
(\mathrm{mg} / \mathrm{L})\end{array}$ & $\begin{array}{c}\text { PTD } \\
(\mu \mathrm{g} / \mathrm{L})\end{array}$ & $\begin{array}{c}\text { Ortofosfato } \\
(\mu \mathrm{g} / \mathrm{L})\end{array}$ & $\begin{array}{c}\text { Fósforo } \\
\text { total } \\
(\mu \mathrm{g} / \mathrm{L})\end{array}$ & $\begin{array}{c}\text { NTK } \\
(\mathrm{mg} / \mathrm{L})\end{array}$ \\
\hline \multicolumn{8}{|l|}{ 19/10/2004 (08:00 h) } \\
\hline T0 afluente & 2,1 & 8,9 & 7,9 & 733,8 & 178,2 & 6788 & 13,1 \\
\hline T0 sub-superfície & 2,01 & 18,9 & 13,9 & 1142,3 & 649,5 & 4100 & 40,1 \\
\hline T0 camada intermediária & 1,9 & 20,8 & 11,6 & 1372,3 & 1118 & 2973 & 34,5 \\
\hline T0 interface água-sedimento & 2,1 & 29,4 & 18,9 & 286,8 & 1147,7 & 4238,8 & 29,2 \\
\hline T0 efluente & 1,9 & 3,7 & 18,9 & 2913,1 & 1009,5 & 3844,8 & 28,8 \\
\hline \multicolumn{8}{|l|}{ 19/10/2004 (18:00 h) } \\
\hline T2 afluente & 1,9 & 4,6 & 17,1 & 1803,6 & 1997,9 & 7010 & 25,9 \\
\hline T2 sub-superfície & 1,7 & 3,2 & 18,5 & 1296,2 & 1057,8 & 3644 & 26,5 \\
\hline T2 camada intermediária & 1,5 & 5,8 & 18,9 & 2013,5 & 1874,5 & 2679,2 & 26,1 \\
\hline T2 interface água-sedimento & 1,6 & 5,2 & 22,5 & 1504,4 & 1619,4 & 5243,2 & 27,7 \\
\hline T2 efluente & 1,2 & 3,6 & 20,4 & 639,9 & 513,6 & 1494 & 28 \\
\hline \multicolumn{8}{|l|}{ 20/10/2004 (02:00 h) } \\
\hline T3 afluente & 1,4 & 0,2 & 15,6 & 1561,2 & 1267,9 & 10292 & 20,9 \\
\hline T3 sub-superfície & 1,5 & 4,02 & 18,7 & 2962 & 1845,6 & 3937,6 & 29,5 \\
\hline T3 camada intermediária & 1,6 & 3,7 & 25,2 & 3259 & 2485 & 4304,8 & 31,9 \\
\hline T3 interface água-sedimento & 1,5 & 4,7 & 48,6 & 3835 & 2111,5 & 3305,6 & 29,8 \\
\hline \multicolumn{8}{|l|}{ 20/10/2004 (08:00 h) } \\
\hline T4 afluente & 3,0 & 0,9 & 36,8 & 6831 & 3751,5 & 5528,4 & 53,6 \\
\hline T4 sub-superfície & 1,7 & 2,14 & 19,4 & 1561,9 & 1375,8 & 4244 & 28,9 \\
\hline T4 camada intermediária & 1,6 & 1,7 & 19,6 & 1699,5 & 1633,6 & 3701 & 30,9 \\
\hline T4 interface água-sedimento & 1,6 & 1,7 & 23,6 & 2776 & 2709,5 & 4813,2 & 33,7 \\
\hline
\end{tabular}


Tabela B3: Ácidos orgânicos na lagoa anaeróbia - Coleta na primavera (outubro 2004)

\begin{tabular}{|c|c|c|c|c|c|c|}
\hline $\begin{array}{c}\begin{array}{c}\text { Locais de amostragem } \\
\text { (Cajati) }\end{array} \\
\end{array}$ & $\begin{array}{l}\text { Ácido } \\
\text { acético } \\
\text { (mg/L) }\end{array}$ & $\begin{array}{c}\text { Ácido } \\
\text { propiônico } \\
\text { (mg/L) }\end{array}$ & $\begin{array}{c}\begin{array}{c}\text { Ácido } \\
\text { butírico } \\
\text { (mg/L) }\end{array} \\
\end{array}$ & $\begin{array}{c}\text { Ácido } \\
\text { isovalérico } \\
\text { (mg/L) }\end{array}$ & $\begin{array}{c}\begin{array}{c}\text { Ácido } \\
\text { valérico } \\
\text { (mg/L) }\end{array} \\
\end{array}$ & $\begin{array}{c}\text { Ácido } \\
\text { caproico } \\
\text { (mg/L) }\end{array}$ \\
\hline $\begin{array}{l}\text { 19/10/2004 (08:00 h) } \\
\text { T0 afluente }\end{array}$ & nd & nd & nd & nd & nd & nd \\
\hline T0 sub-superfície & nd & nd & nd & nd & nd & nd \\
\hline T0 camada intermediária & 4,2 & nd & nd & nd & nd & nd \\
\hline T0 interface água-sedimento & nd & nd & nd & nd & nd & nd \\
\hline T0 efluente & nd & nd & nd & nd & nd & nd \\
\hline \multicolumn{7}{|l|}{ 19/10/2004 (18:00 h) } \\
\hline $\mathrm{T} 2$ afluente & 26,9 & 2,8 & 0,2 & 0,2 & 0,7 & nd \\
\hline T2 sub-superficie & nd & nd & nd & 0,034 & 0,4 & nd \\
\hline $\mathrm{T} 2$ camada intermediária & nd & nd & nd & nd & nd & nd \\
\hline $\mathrm{T} 2$ interface água-sedimento & nd & nd & nd & 0,015 & nd & nd \\
\hline $\mathrm{T} 2$ efluente & nd & nd & nd & nd & nd & nd \\
\hline \multicolumn{7}{|l|}{ 20/10/2004 (08:00 h) } \\
\hline T4 afluente & 22,8 & 5,8 & 0,9 & 0,5 & 0,9 & nd \\
\hline T4 sub-superfície & nd & nd & nd & nd & nd & nd \\
\hline T4 camada intermediária & nd & nd & nd & nd & nd & nd \\
\hline T4 interface água-sedimento & 10,6 & nd & nd & 1,4 & nd & nd \\
\hline T4 efluente & nd & nd & nd & nd & 1,24 & 0,8 \\
\hline
\end{tabular}

nd: abaixo do limite de detecção

Valores mínimos detectáveis: ácido acético: $5,2 \mathrm{mg} / \mathrm{L}$; ácido propiônico: $4,9 \mathrm{mg} / \mathrm{L}$; ácido butírico: 4,8 mg/L; ácido isovalérico: 4,4mg/L; ácido valérico: 4,7 mg/L; ácido caproico: 4,6 mg/L 
Tabela B4: Dados obtidos na lagoa facultativa - Coleta na primavera (outubro 2004)

\begin{tabular}{|c|c|c|c|c|c|c|c|}
\hline $\begin{array}{c}\text { Locais de amostragem } \\
\text { (Cajati) }\end{array}$ & pH & $\begin{array}{c}\text { Temperatura } \\
\left({ }^{\circ} \mathrm{C}\right)\end{array}$ & $\begin{array}{c}\text { Oxigênio } \\
\text { dissolvido } \\
\text { (mg/L) }\end{array}$ & $\begin{array}{l}\text { Sulfato } \\
(\mathrm{mg} / \mathrm{L})\end{array}$ & $\begin{array}{l}\text { DQOf } \\
(\mathrm{mg} / \mathrm{L})\end{array}$ & $\begin{array}{l}\text { DQOb } \\
\text { (mg/L) }\end{array}$ & $\begin{array}{c}\mathrm{SSV} \\
(\mathrm{mg} / \mathrm{L})\end{array}$ \\
\hline \multicolumn{8}{|l|}{ 19/10/2004 (08:00 h) } \\
\hline T0 afluente & 9,1 & 22,9 & 0,3 & 20 & 25 & 122 & 213 \\
\hline T0 sub-superfície & 8,8 & 23,5 & 0,3 & 15 & 46 & 106 & 180 \\
\hline T0 camada intermediária & 9,0 & 23,4 & 0,1 & 14 & 45 & 143 & 150 \\
\hline T0 interface água-sedimento & 9,1 & 23,3 & 0,1 & 12 & 61 & 101 & 73 \\
\hline T0 efluente & 8,8 & 24,3 & 3,7 & 4 & 67 & 125 & 80 \\
\hline \multicolumn{8}{|l|}{ 19/10/2004 (18:00 h) } \\
\hline T2 afluente & 8,8 & 24 & 0,2 & 11 & 67 & 87 & 6 \\
\hline T2 sub-superfície & 9,1 & 25,2 & 3,2 & 15 & 85 & 132 & 126 \\
\hline T2 camada intermediária & 9,2 & 25,2 & 2,7 & 19 & 10 & 124 & 116 \\
\hline $\mathrm{T} 2$ interface água-sedimento & 9,1 & 24,8 & 1,3 & 11 & 35 & 138 & 146 \\
\hline T2 efluente & 9,2 & 24,9 & 3,8 & 17 & 48 & 119 & 223 \\
\hline \multicolumn{8}{|l|}{ 20/10/2004 (02:00 h) } \\
\hline T3 sub-superfície & 8,9 & 23,5 & 0,14 & & & 98 & \\
\hline T3 camada intermediária & 8,9 & 23,5 & 0,04 & & & 69 & \\
\hline T3 interface água-sedimento & 8,9 & 23,5 & 0,04 & & & 62 & \\
\hline T3 efluente & 8,9 & 23,4 & 2,2 & & & 84 & \\
\hline \multicolumn{8}{|l|}{ 20/10/2004 (08:00 h) } \\
\hline T4 afluente & 8,9 & 23,0 & 0,13 & 18 & 41 & & 186 \\
\hline T4 sub-superfície & 8,8 & 23,0 & 0,8 & 15 & 46 & 80 & 196 \\
\hline T4 camada intermediária & 8,9 & 23,0 & 0,04 & 18 & 51 & 156 & 220 \\
\hline T4 interface água-sedimento & 8,8 & 23,0 & 0,04 & 17 & 54 & 150 & 243 \\
\hline T4 efluente & 8,9 & 23,1 & 2,0 & 18 & 59 & 149 & 160 \\
\hline
\end{tabular}


Tabela B5: Nutrientes totais e dissolvidos na lagoa facultativa - Coleta na primavera (outubro 2004)

\begin{tabular}{|c|c|c|c|c|c|c|c|}
\hline \multirow{2}{*}{$\begin{array}{l}\text { Locais de amostragem } \\
\text { (Cajati) }\end{array}$} & \multicolumn{5}{|c|}{ Nutrientes dissolvidos } & \multicolumn{2}{|c|}{ Nutrientes totais } \\
\hline & $\begin{array}{l}\text { Nitrato } \\
\text { (mg/L) }\end{array}$ & $\begin{array}{l}\text { Nitrito } \\
(\mu \mathrm{g} / \mathrm{L})\end{array}$ & $\begin{array}{c}\text { Nitrogênio } \\
\text { amoniacal } \\
(\mathrm{mg} / \mathrm{L})\end{array}$ & $\begin{array}{l}\text { PTD } \\
(\mu \mathrm{g} / \mathrm{L})\end{array}$ & $\begin{array}{l}\text { Ortofosfato } \\
(\mu \mathrm{g} / \mathrm{L})\end{array}$ & $\begin{array}{c}\text { Fósforo } \\
\text { total } \\
(\mu \mathrm{g} / \mathrm{L})\end{array}$ & $\begin{array}{c}\text { NTK } \\
(\mathrm{mg} / \mathrm{L})\end{array}$ \\
\hline \multicolumn{8}{|l|}{ 19/10/2004 (08:00 h) } \\
\hline T0 afluente & 1,9 & 3,7 & 18,9 & 2913,1 & 1009,5 & 3844,8 & 28,8 \\
\hline T0 sub-superfície & 1,4 & 3,9 & 15,1 & 816,7 & 680,4 & 4849 & 29,5 \\
\hline T0 camada intermediária & 1,3 & 5,1 & 12,2 & 1445 & 573,6 & 5988,8 & 32,7 \\
\hline T0 interface água-sedimento & 1,4 & 4,1 & 12,3 & 1292,5 & 909,4 & 4525,2 & 23,1 \\
\hline T0 efluente & 1,6 & 18,7 & 9,2 & 310,7 & 44,8 & 12332 & 30,4 \\
\hline \multicolumn{8}{|l|}{ 19/10/2004 (18:00 h) } \\
\hline T2 afluente & 1,3 & 3,6 & 20,4 & 639,9 & 513,6 & 1494 & 28 \\
\hline T2 sub-superfície & 1,2 & 4,1 & 6,6 & 373,2 & 159,6 & 4196 & 31,6 \\
\hline T2 camada intermediária & 1,4 & 16,7 & 9,8 & 201,1 & 251,3 & 2125,2 & 23,2 \\
\hline T2 interface água-sedimento & 1,2 & 1,9 & 10,9 & 405,7 & 379 & 5251,6 & 26,5 \\
\hline T2 efluente & 1,4 & 14,4 & 9,2 & 188,8 & 39,9 & 4090 & 23,3 \\
\hline \multicolumn{8}{|l|}{ 20/10/2004 (02:00 h) } \\
\hline T3 sub-superfície & 1,2 & 2,02 & 10 & 323,2 & 1626 & 4190 & 24,5 \\
\hline T3 camada intermediária & 1,4 & 1,8 & 11,8 & 187,7 & 64,8 & 5176,4 & 27,4 \\
\hline T3 interface água-sedimento & 1,3 & 2,9 & 8,6 & 183,7 & 50,6 & 4088 & 22,7 \\
\hline T3 efluente & 1,1 & 3,9 & 11,5 & 237,6 & 67,8 & 4061,2 & 22,6 \\
\hline \multicolumn{8}{|l|}{ 20/10/2004 (08:00 h) } \\
\hline \multicolumn{8}{|l|}{ T4 afluente } \\
\hline T4 sub-superfície & 1,5 & 6,3 & 9,1 & 278,5 & 112,6 & 4060 & 22,4 \\
\hline T4 camada intermediária & 1,8 & 9,1 & 10,5 & 246,9 & 36,6 & 6130,8 & 31,2 \\
\hline T4 interface água-sedimento & 1,4 & 4,3 & 13,0 & 245,2 & 64,3 & 4244,8 & 30,9 \\
\hline T4 efluente & 1,6 & 5,5 & 10,9 & 194,6 & 33,9 & 7759,2 & 33,3 \\
\hline
\end{tabular}


Tabela B6: Ácidos orgânicos na lagoa facultativa - Coleta na primavera (outubro 2004)

\begin{tabular}{|c|c|c|c|c|c|c|}
\hline $\begin{array}{l}\text { Locais de amostragem } \\
\text { (Cajati) }\end{array}$ & $\begin{array}{l}\text { Ácido } \\
\text { acético } \\
\text { (mg/L) }\end{array}$ & $\begin{array}{c}\text { Ácido } \\
\text { propiônico } \\
\text { (mg/L) }\end{array}$ & $\begin{array}{c}\begin{array}{c}\text { Ácido } \\
\text { butírico } \\
\text { (mg/L) }\end{array} \\
\end{array}$ & $\begin{array}{c}\text { Ácido } \\
\text { isovalérico } \\
\text { (mg/L) }\end{array}$ & $\begin{array}{c}\text { Ácidoo } \\
\text { valérico } \\
\text { (mg/L) }\end{array}$ & $\begin{array}{c}\text { Ácido } \\
\text { caproico } \\
\text { (mg/L) }\end{array}$ \\
\hline $\begin{array}{l}\text { 19/10/2004 (08:00 h) } \\
\text { T0 afluente }\end{array}$ & nd & nd & nd & nd & nd & nd \\
\hline T0 sub-superfície & nd & nd & nd & 0,072 & nd & nd \\
\hline $\mathrm{T} 0$ camada intermediária & nd & nd & nd & 0,057 & nd & nd \\
\hline T0 interface água-sedimento & nd & nd & nd & 0,048 & nd & nd \\
\hline T0 efluente & nd & nd & nd & 0,047 & nd & nd \\
\hline \multicolumn{7}{|l|}{ 19/10/2004 (18:00 h) } \\
\hline $\mathrm{T} 2$ afluente & nd & nd & nd & nd & nd & nd \\
\hline $\mathrm{T} 2$ sub-superfície & nd & nd & nd & nd & nd & nd \\
\hline T2 camada intermediária & nd & nd & nd & 0,3 & nd & nd \\
\hline T2 interface água-sedimento & 34,9 & nd & nd & 1,2 & nd & nd \\
\hline T2 efluente & nd & nd & nd & nd & nd & nd \\
\hline \multicolumn{7}{|l|}{ 20/10/2004 (08:00 h) } \\
\hline T4 afluente & nd & nd & nd & nd & 1,2 & 0,8 \\
\hline T4 sub-superfície & 7,8 & nd & nd & 0,3 & 0,6 & 1,2 \\
\hline T4 camada intermediária & nd & nd & nd & nd & nd & nd \\
\hline T4 interface água-sedimento & nd & nd & nd & nd & nd & nd \\
\hline T4 efluente & nd & nd & nd & nd & nd & nd \\
\hline
\end{tabular}

nd: abaixo do limite de deteç̧ão

Valores mínimos detectáveis: ácido acético: 5,2 mg/L; ácido propiônico: 4,9 mg/L; ácido butírico: 4,8 mg/L; ácido isovalérico: 4,4 $\mathrm{mg} / \mathrm{L}$; ácido valérico: $4,7 \mathrm{mg} / \mathrm{L}$; ácido caproico: $4,6 \mathrm{mg} / \mathrm{L}$ 
Tabela B7: Dados obtidos na lagoa anaeróbia - Coleta no verão (janeiro 2005)

\begin{tabular}{|c|c|c|c|c|c|c|c|}
\hline $\begin{array}{l}\text { Locais de amostragem } \\
\text { (Cajati) }\end{array}$ & pH & $\begin{array}{l}\text { Temperatura } \\
\quad\left({ }^{\circ} \mathrm{C}\right)\end{array}$ & $\begin{array}{c}\text { Oxigênio } \\
\text { dissolvido } \\
\text { (mg/L) }\end{array}$ & $\begin{array}{l}\text { Sulfato } \\
(\mathrm{mg} / \mathrm{L})\end{array}$ & $\begin{array}{l}\text { DQOf } \\
(\mathrm{mg} / \mathrm{L})\end{array}$ & $\begin{array}{l}\text { DQOb } \\
\text { (mg/L) }\end{array}$ & $\begin{array}{c}\text { SSV } \\
(\mathrm{mg} / \mathrm{L})\end{array}$ \\
\hline \multicolumn{8}{|l|}{ 24/01/2005 (08:00 h) } \\
\hline T0 afluente & 8,3 & 25,8 & 3,4 & 28 & 39 & 172 & 27 \\
\hline T0 sub-superfície & 8,8 & 27,7 & 2,5 & 16 & 104 & 225 & 0 \\
\hline T0 camada intermediária & 9,1 & 25,3 & 0,1 & 27 & 97 & 203 & 0 \\
\hline $\mathrm{T} 0$ interface água-sedimento & 8,9 & 25,1 & 0,1 & 18 & 146 & 206 & 57 \\
\hline T0 efluente & 9,4 & 26,3 & 0,3 & 19 & 98 & 199 & 0 \\
\hline \multicolumn{8}{|l|}{ 24/01/2005 (14:00 h) } \\
\hline T1 afluente & 9,4 & 26,2 & 2,6 & 54 & 150,3 & 290 & 60 \\
\hline T1 sub-superfície & 10,9 & 33,1 & 7,4 & 21 & 44,2 & 130 & 0 \\
\hline T1 camada intermediária & 9,2 & 25,3 & 0,1 & 18 & 91,1 & 130 & 13 \\
\hline $\mathrm{T} 1$ interface água-sedimento & 9,2 & 25,2 & 0,1 & 16 & 71,4 & 121 & 40 \\
\hline T1 efluente & 10,1 & 27,0 & 1,3 & 11 & 86,2 & 148 & 93 \\
\hline \multicolumn{8}{|l|}{ 24/01/2005 (20:00 h) } \\
\hline $\mathrm{T} 2$ afluente & 9,5 & 26,3 & 2,1 & 41 & 108,4 & 339 & 0 \\
\hline T2 sub-superfície & 11,1 & 30,7 & 5,9 & 9 & 56,5 & 139 & 0 \\
\hline T2 camada intermediária & 9,3 & 25,3 & 0,1 & 16 & 76,3 & 163 & 40 \\
\hline $\mathrm{T} 2$ interface água-sedimento & 9,1 & 25,1 & 0,1 & 3 & 81,2 & 172 & 13 \\
\hline $\mathrm{T} 2$ efluente & 9,4 & 25,9 & 2,6 & 16 & 59,0 & 139 & 70 \\
\hline \multicolumn{8}{|l|}{ 25/01/2005 (02:00 h) } \\
\hline T3 afluente & 8,8 & 26,1 & 3,1 & 32 & 36,8 & 88 & 37 \\
\hline T3 sub-superfície & 9,6 & 28,3 & 4,0 & 13 & 44,2 & 118 & 53 \\
\hline T3 camada intermediária & 9,1 & 25,4 & 0,1 & 28 & 44,2 & 136 & 40 \\
\hline T3 interface água-sedimento & 9,1 & 25,3 & 0,1 & 18 & 41,7 & 100 & 47 \\
\hline $\mathrm{T} 3$ efluente & 9,4 & 26,4 & 1,4 & 16 & 59,0 & 106 & 70 \\
\hline \multicolumn{8}{|l|}{ 25/01/2005 (08:00 h) } \\
\hline T4 afluente & 9,5 & 25,9 & 2,7 & 40 & 21,9 & 46 & 7 \\
\hline T4 sub-superfície & 11,9 & 27,2 & 1,0 & 15 & 44,2 & 106 & 57 \\
\hline T4 camada intermediária & 12,2 & 25,4 & 0,1 & 17 & 4,7 & 85 & 77 \\
\hline T4 interface água-sedimento & 11,7 & 25,2 & 0,1 & 15 & 12,1 & 89 & 0 \\
\hline T4 efluente & 9,7 & 26,7 & 2,3 & 19 & 7,2 & 89 & 50 \\
\hline
\end{tabular}


Tabela B8: Nutrientes totais e dissolvidos na lagoa anaeróbia - Coleta no verão (janeiro 2005)

\begin{tabular}{|c|c|c|c|c|c|c|c|}
\hline \multirow{2}{*}{$\begin{array}{l}\text { Locais de amostragem } \\
\text { (Cajati) }\end{array}$} & \multicolumn{5}{|c|}{ Nutrientes dissolvidos } & \multicolumn{2}{|c|}{ Nutrientes totais } \\
\hline & $\begin{array}{l}\text { Nitrato } \\
(\mathrm{mg} / \mathrm{L})\end{array}$ & $\begin{array}{l}\text { Nitrito } \\
(\mu \mathrm{g} / \mathrm{L})\end{array}$ & $\begin{array}{c}\text { Nitrogênio } \\
\text { amoniacal } \\
(\mathrm{mg} / \mathrm{L})\end{array}$ & $\begin{array}{c}\text { PTD } \\
(\mu \mathrm{g} / \mathrm{L})\end{array}$ & $\begin{array}{l}\text { Ortofosfato } \\
(\mu \mathrm{g} / \mathrm{L})\end{array}$ & $\begin{array}{c}\text { Fósforo } \\
\text { total } \\
(\mu \mathrm{g} / \mathrm{L})\end{array}$ & $\begin{array}{c}\text { NTK } \\
(\mathrm{mg} / \mathrm{L})\end{array}$ \\
\hline \multicolumn{8}{|l|}{ 24/01/2005 (08:00 h) } \\
\hline T0 afluente & 1,4 & 29,5 & 4,6 & 224,7 & 143,4 & 392,8 & 4,7 \\
\hline T0 sub-superfície & 1,7 & 8,0 & 7,5 & 1103,7 & 831,9 & 1905,2 & 11,4 \\
\hline T0 camada intermediária & 1,9 & 11,3 & 3,4 & 1358,9 & 1096 & 1017 & 3,7 \\
\hline T0 interface água-sedimento & 0,7 & 4,1 & 10,1 & 1163,2 & 994,7 & 1371,2 & 12,3 \\
\hline T0 efluente & 1,6 & 4,8 & 8,6 & 996,6 & 1003,2 & 1179,5 & 11,9 \\
\hline $\begin{array}{l}\text { 24/01/2005 }(\mathbf{1 4 : 0 0 ~ h )} \\
\text { T1 afluente }\end{array}$ & 3,7 & 13,9 & 14,5 & 2635,7 & 2017,1 & 1142 & 30,2 \\
\hline T1 sub-superfície & 1,8 & 8,1 & 5,5 & 1069,3 & 878,1 & 1023 & 10,7 \\
\hline T1 camada intermediária & 1,6 & 8,6 & 8,3 & 820,4 & 986,1 & 1540,5 & 18,8 \\
\hline T1 interface água-sedimento & 1,6 & 10,0 & 10,2 & 941 & 1051,6 & 1668,1 & 14,5 \\
\hline T1 efluente & 1,7 & 6 & 11,6 & 992,2 & 984,3 & 862,7 & 26,2 \\
\hline $\begin{array}{l}\text { 24/01/2005 }(\mathbf{2 0 : 0 0 ~ h )} \\
\mathrm{T} 2 \text { afluente }\end{array}$ & 2,3 & 2,9 & 8,3 & 762,7 & 765,8 & 2012,2 & 13,8 \\
\hline T2 sub-superfície & 1,7 & 6,5 & 6,1 & 891,3 & 253,1 & 883,7 & 9,5 \\
\hline T2 camada intermediária & 1,7 & 8,1 & 7,9 & 1162,7 & 962,9 & 1432,1 & 11,5 \\
\hline T2 interface água-sedimento & 1,8 & 9,2 & 10,1 & 1116,6 & 1076,2 & 1812,2 & 10,8 \\
\hline $\mathrm{T} 2$ efluente & 1,6 & 10,4 & 10 & 124,9 & 1086,3 & 2053 & 14,1 \\
\hline $\begin{array}{l}\text { 25/01/2005 }(\mathbf{0 2 : 0 0 ~ h )} \\
\text { T3 afluente }\end{array}$ & 1,8 & 58,9 & 2,9 & 105,2 & 1299,2 & 646,0 & 17,2 \\
\hline T3 sub-superfície & 1,4 & 10,9 & 5,8 & 693,2 & 637,3 & 1179,3 & 8,6 \\
\hline T3 camada intermediária & 1,6 & 4,8 & 8,9 & 734,5 & 680,1 & 1715,7 & 10,1 \\
\hline T3 interface água-sedimento & 1,4 & 5,5 & 8,9 & 1012,9 & 921,3 & 1718,2 & 11,1 \\
\hline T3 efluente & 0,6 & 4,8 & 8,9 & 882,1 & 766,5 & 1645,5 & 10,7 \\
\hline $\begin{array}{l}\text { 25/01/2005 }(\mathbf{0 8 : 0 0 ~ h )} \\
\text { T4 afluente }\end{array}$ & 2,3 & 7,7 & 1,8 & 60,2 & 550,1 & 251,3 & 3,9 \\
\hline T4 sub-superfície & 1,6 & 9,5 & 5,1 & 672,9 & 587 & 1807,5 & 9,2 \\
\hline T4 camada intermediária & 1,5 & 6,0 & 8,3 & 786,3 & 668,6 & 1886,1 & 9,1 \\
\hline T4 interface água-sedimento & 1,6 & 2,1 & 8,7 & 992,1 & 1060,2 & 1916,9 & 10,8 \\
\hline T4 efluente & 1,8 & 13,8 & 7,1 & 913,1 & 847,9 & 1479,8 & 12,9 \\
\hline
\end{tabular}


Tabela B9: Ácidos orgânicos na lagoa anaeróbia - Coleta no verão (janeiro 2005)

\begin{tabular}{|c|c|c|c|c|c|c|c|}
\hline $\begin{array}{c}\text { Locais de amostragem } \\
\text { Cajati }\end{array}$ & $\begin{array}{c}\text { Ácido } \\
\text { acético } \\
(\mathrm{mg} / \mathrm{L})\end{array}$ & $\begin{array}{c}\text { Ácido } \\
\text { propiônico } \\
\text { (mg/L) }\end{array}$ & $\begin{array}{c}\text { Ácido } \\
\text { isobutírico } \\
\text { (mg/L) }\end{array}$ & $\begin{array}{c}\text { Ácido } \\
\text { butírico } \\
\text { (mg/L) }\end{array}$ & $\begin{array}{c}\text { Ácido } \\
\text { isovalérico } \\
\text { (mg/L) }\end{array}$ & $\begin{array}{c}\text { Ácido } \\
\text { valérico } \\
(\mathrm{mg} / \mathrm{L})\end{array}$ & $\begin{array}{c}\text { Ácido } \\
\text { caproico } \\
(\mathrm{mg} / \mathrm{L}) \\
\end{array}$ \\
\hline \multicolumn{8}{|l|}{ 24/01/2005 (08:00 h) } \\
\hline T0 afluente & nd & nd & nd & nd & nd & nd & nd \\
\hline T0 sub-superfície & nd & nd & nd & nd & nd & nd & nd \\
\hline T0 camada intermediária & 13 & nd & nd & nd & nd & nd & nd \\
\hline T0 interface água-sedimento & 25,5 & nd & nd & nd & nd & nd & nd \\
\hline T0 efluente & 16 & nd & nd & nd & nd & nd & nd \\
\hline \multicolumn{8}{|l|}{ 24/01/2005 (14:00 h) } \\
\hline T1 afluente & 33,5 & 2,2 & nd & nd & nd & nd & nd \\
\hline T1 sub-superfície & nd & nd & nd & nd & nd & nd & nd \\
\hline T1 camada intermediária & 18 & nd & nd & nd & nd & nd & nd \\
\hline T1 interface água-sedimento & 22,5 & nd & nd & nd & nd & nd & nd \\
\hline T1 efluente & 13,0 & nd & nd & nd & nd & nd & nd \\
\hline \multicolumn{8}{|l|}{ 24/01/2005 (20:00 h) } \\
\hline $\mathrm{T} 2$ afluente & 12 & nd & nd & nd & nd & nd & nd \\
\hline T2 sub-superfície & $\mathrm{Nd}$ & nd & nd & nd & nd & nd & nd \\
\hline T2 camada intermediária & 16,5 & nd & nd & nd & nd & nd & nd \\
\hline T2 interface água-sedimento & 22,0 & nd & nd & nd & nd & nd & nd \\
\hline $\mathrm{T} 2$ efluente & 18 & nd & nd & nd & nd & nd & nd \\
\hline \multicolumn{8}{|l|}{ 25/01/2005 (02:00 h) } \\
\hline $\mathrm{T} 3$ afluente & nd & nd & nd & nd & nd & nd & nd \\
\hline T3 sub-superfície & nd & nd & nd & nd & nd & nd & nd \\
\hline T3 camada intermediária & 10 & nd & nd & nd & nd & nd & nd \\
\hline T3 interface água-sedimento & 15,4 & nd & nd & nd & nd & nd & nd \\
\hline T3 efluente & 17,4 & nd & nd & nd & nd & nd & nd \\
\hline \multicolumn{8}{|l|}{ 25/01/2005 (08:00 h) } \\
\hline T4 afluente & nd & nd & nd & nd & nd & nd & nd \\
\hline T4 sub-superfície & nd & nd & nd & nd & nd & nd & nd \\
\hline T4 camada intermediária & 19 & nd & nd & nd & nd & nd & nd \\
\hline T4 interface água-sedimento & 28 & nd & nd & nd & nd & nd & nd \\
\hline T4 efluente & 8,7 & nd & nd & nd & nd & nd & nd \\
\hline
\end{tabular}

nd: abaixo do limite de detecção
Valores mínimos detectáveis: ácido acético: $5,2 \mathrm{mg} / \mathrm{L}$; ácido propiônico: $4,8 \mathrm{mg} / \mathrm{L}$; ácido butírico: $4,8 \mathrm{mg} / \mathrm{L} ;$ ácido isovalérico: $4,4 \mathrm{mg} / \mathrm{L}$; ácido valérico: $4,7 \mathrm{mg} / \mathrm{L}$; ácido caproico: $4,6 \mathrm{mg} / \mathrm{L}$ 
Tabela B10: Dados obtidos na lagoa facultativa - Coleta no verão (janeiro 2005)

\begin{tabular}{|c|c|c|c|c|c|c|c|}
\hline $\begin{array}{c}\text { Locais de amostragem } \\
\text { (Cajati) }\end{array}$ & pH & $\begin{array}{l}\text { Temperatura } \\
\left({ }^{\circ} \mathrm{C}\right)\end{array}$ & $\begin{array}{c}\text { Oxigênio } \\
\text { dissolvido } \\
\text { (mg/L) }\end{array}$ & $\begin{array}{l}\text { Sulfato } \\
\text { (mg/L) }\end{array}$ & $\begin{array}{l}\text { DQOf } \\
\text { (mg/L) }\end{array}$ & $\begin{array}{l}\text { DQOb } \\
\text { (mg/L) }\end{array}$ & $\begin{array}{c}\text { SSV } \\
(\mathrm{mg} / \mathrm{L})\end{array}$ \\
\hline \multicolumn{8}{|l|}{ 24/01/2005 (08:00 h) } \\
\hline T0 afluente & 9,4 & 26,3 & 0,3 & 19 & 98 & 199 & 0 \\
\hline T0 sub-superfície & 10,5 & 28,1 & 4,9 & 1 & 59 & 297 & 80 \\
\hline T0 camada intermediária & 9,7 & 25,8 & 0,1 & 12 & 64 & 288 & 57 \\
\hline T0 interface água-sedimento & 9,7 & 25,4 & 0,1 & 11 & 53 & 243 & 0 \\
\hline T0 efluente & 9,3 & 26,4 & 1,9 & 11 & 74 & 331 & 97 \\
\hline \multicolumn{8}{|l|}{ 24/01/2005 (14:00 h) } \\
\hline $\mathrm{T} 1$ afluente & 10,1 & 27,0 & 1,3 & 11 & 86,2 & 148 & 93 \\
\hline T1 sub-superfície & 12,1 & 32,6 & 9,5 & 2 & 49,1 & 166 & 57 \\
\hline T1 camada intermediária & 9,5 & 26,1 & 0,02 & 14 & 63,9 & 169 & 80 \\
\hline T1 interface água-sedimento & 10 & 25,4 & 0,1 & 8 & 44,2 & 148 & 63 \\
\hline T1 efluente & 8,6 & 27,3 & 2,9 & 12 & 29,4 & 160 & 117 \\
\hline \multicolumn{8}{|l|}{ 24/01/2005 (20:00 h) } \\
\hline $\mathrm{T} 2$ afluente & 9,4 & 25,9 & 2,6 & 16 & 59,0 & 139 & 70 \\
\hline T2 sub-superfície & 11,8 & 30,8 & 6,7 & 0 & 86,2 & 203 & 80 \\
\hline T2 camada intermediária & 10,1 & 26,4 & 0,7 & 2 & 81,2 & 203 & 73 \\
\hline $\mathrm{T} 2$ interface água-sedimento & 9,7 & 25,4 & 0,1 & 1 & 73,8 & 200 & 87 \\
\hline $\mathrm{T} 2$ efluente & 9,5 & 26,7 & 3,5 & 8 & 36,8 & 245 & 0 \\
\hline \multicolumn{8}{|l|}{ 25/01/2005 (02:00 h) } \\
\hline T3 afluente & 9,4 & 26,4 & 1,4 & 16 & 59,0 & 106 & 70 \\
\hline T3 sub-superfície & 11,3 & 28,8 & 3,2 & 11 & 59,0 & 133 & 57 \\
\hline T3 camada intermediária & 9,9 & 26,7 & 0,2 & 14 & 61,5 & 124 & 80 \\
\hline T3 interface água-sedimento & 9,7 & 25,5 & 0,1 & 8 & 36,8 & 157 & 0 \\
\hline T3 efluente & 9,4 & 26,7 & 2,3 & 10 & 29,4 & 160 & 53 \\
\hline \multicolumn{8}{|l|}{ 25/01/2005 (08:00 h) } \\
\hline T4 afluente & 9,7 & 26,7 & 2,3 & 19 & 7,2 & 89 & 50 \\
\hline T4 sub-superfície & 11,3 & 27,6 & 2,7 & 9 & 19,5 & 118 & 0 \\
\hline T4 camada intermediária & 10,7 & 26,8 & 0,3 & 15 & 14,6 & 163 & 0 \\
\hline T4 interface água-sedimento & 10,7 & 25,6 & 0,1 & 18 & 34,3 & 142 & 0 \\
\hline T4 efluente & 9,9 & 26,1 & 2,3 & 5 & 21,9 & 151 & 0 \\
\hline
\end{tabular}


Tabela B11: Nutrientes totais e dissolvidos na lagoa facultativa - Coleta no verão (janeiro 2005)

\begin{tabular}{|c|c|c|c|c|c|c|c|}
\hline \multirow[b]{2}{*}{$\begin{array}{c}\text { Locais de amostragem } \\
\text { (Cajati) }\end{array}$} & \multicolumn{5}{|c|}{ Nutrientes dissolvidos } & \multicolumn{2}{|c|}{ Nutrientes totais } \\
\hline & $\begin{array}{l}\text { Nitrato } \\
\text { (mg/L) }\end{array}$ & $\begin{array}{l}\text { Nitrito } \\
(\mu \mathrm{g} / \mathrm{L})\end{array}$ & $\begin{array}{l}\text { Nitrogênio } \\
\text { amoniacal } \\
(\mathrm{mg} / \mathrm{L})\end{array}$ & $\begin{array}{l}\text { PTD } \\
(\mu \mathrm{g} / \mathrm{L})\end{array}$ & $\begin{array}{l}\text { Ortofosfato } \\
(\mu \mathrm{g} / \mathrm{L})\end{array}$ & $\begin{array}{c}\text { Fósforo } \\
\text { Total } \\
(\mu \mathrm{g} / \mathrm{L})\end{array}$ & $\begin{array}{c}\text { NTK } \\
(\mathrm{mg} / \mathrm{L})\end{array}$ \\
\hline $\begin{array}{l}\mathbf{2 4 / 0 1 / 2 0 0 5}(\mathbf{0 8 : 0 0} \mathbf{h}) \\
\text { T0 afluente }\end{array}$ & 1,6 & 4,8 & 8,6 & 996,6 & 1003,2 & 1179,5 & 11,9 \\
\hline T0 sub-superfície & 2,1 & 27,8 & 2,5 & 880,9 & 2589,2 & 1952,1 & 10,3 \\
\hline T0 camada intermediária & 2,1 & 22,2 & 2,8 & 841,1 & 784,2 & 1573,6 & 11,3 \\
\hline T0 interface água-sedimento & 1,8 & 10,6 & 3,3 & 959,8 & 989,5 & 2709 & 9,3 \\
\hline T0 efluente & 1,9 & 16,4 & 4,2 & 861,6 & 870,1 & 1955,6 & 11,6 \\
\hline \multicolumn{8}{|l|}{ 24/01/2005 (14:00 h) } \\
\hline T1 afluente & 1,7 & 6 & 11,6 & 992,2 & 984,3 & 862,7 & 26,2 \\
\hline T1 sub-superfície & 1,9 & 23,4 & 1,5 & 692,4 & 416,8 & 1415,7 & 8,8 \\
\hline T1 camada intermediária & 1,8 & 12,5 & 4,6 & 832,4 & 769,7 & 1817 & 11,1 \\
\hline T1 interface água-sedimento & 2,1 & 14,3 & 4,8 & 1052,3 & 837,9 & 1970,1 & 12,1 \\
\hline T1 efluente & 1,9 & 13,6 & 4,2 & 724,3 & 273,6 & 1596,9 & 13,3 \\
\hline 24/01/2005 (20:00 h) & & & & & & & \\
\hline T2 afluente & 1,6 & 10,4 & 10 & 124,9 & 1086,3 & 2053 & 14,1 \\
\hline T2 sub-superfície & 2,2 & 32,6 & 1,9 & 702,7 & 490,9 & 1726,2 & 9,9 \\
\hline T2 camada intermediária & 1,9 & 27,8 & 2,9 & 770,3 & 272,3 & 1922,6 & 13,5 \\
\hline T2 interface água-sedimento & 1,9 & 21,9 & 4,5 & 1020,6 & 800,3 & 2156 & 12,2 \\
\hline T2 efluente & 1,7 & 19,9 & 5,9 & 1084,7 & 923,9 & 1828,8 & 16,2 \\
\hline 25/01/2005 (02:00 h) & & & & & & & \\
\hline T3 afluente & 0,6 & 4,8 & 8,9 & 882,1 & 766,5 & 1645,5 & 10,7 \\
\hline T3 sub-superfície & 1,9 & 30,4 & 3,3 & 815,1 & 628,6 & 1664,5 & 10,6 \\
\hline T3 camada intermediária & 1,3 & 11,4 & 4,3 & 789,1 & 657,1 & 1461,3 & 9,9 \\
\hline T3 interface água-sedimento & 1,7 & 3,1 & 6,1 & 929,1 & 860,6 & 2028 & 15,7 \\
\hline T3 efluente & 1,8 & 21,6 & 4,8 & 1002,8 & 843,8 & 2167,4 & 8,5 \\
\hline 25/01/2005 (08:00 h) & & & & & & & \\
\hline T4 afluente & 1,8 & 13,8 & 7,1 & 913,1 & 847,9 & 1479,8 & 12,9 \\
\hline T4 sub-superfície & 1,8 & 24,1 & 2,8 & 699,5 & 596 & 1684,2 & 10,6 \\
\hline T4 camada intermediária & 1,8 & 12,9 & 2,9 & 843,7 & 670,3 & 1873,7 & 11,9 \\
\hline T4 interface água-sedimento & 2,3 & 5,4 & 3,9 & 949,8 & 818,4 & 2166 & 14,1 \\
\hline T4 efluente & 1,7 & 9,2 & 6,3 & 1254,9 & 1078 & 1255,7 & 22,0 \\
\hline
\end{tabular}


Tabela B12: Ácidos orgânicos na lagoa facultativa - Coleta no verão (janeiro 2005)

\begin{tabular}{|c|c|c|c|c|c|c|c|}
\hline $\begin{array}{c}\text { Locais de amostragem } \\
\text { Cajati }\end{array}$ & $\begin{array}{c}\text { Ácido } \\
\text { acético } \\
(\mathrm{mg} / \mathrm{L}) \\
\end{array}$ & $\begin{array}{c}\text { Ácido } \\
\text { propiônico } \\
\text { (mg/L) }\end{array}$ & $\begin{array}{c}\text { Ácido } \\
\text { isobutírico } \\
(\mathrm{mg} / \mathrm{L}) \\
\end{array}$ & $\begin{array}{c}\text { Ácido } \\
\text { butírico } \\
(\mathrm{mg} / \mathrm{L})\end{array}$ & $\begin{array}{c}\text { Ácido } \\
\text { isovalérico } \\
(\mathrm{mg} / \mathrm{L}) \\
\end{array}$ & $\begin{array}{c}\text { Ácido } \\
\text { valérico } \\
(\mathrm{mg} / \mathrm{L})\end{array}$ & $\begin{array}{c}\text { Ácido } \\
\text { caproico } \\
(\mathbf{m g} / \mathrm{L})\end{array}$ \\
\hline \multicolumn{8}{|l|}{ 24/01/2005 (08:00 h) } \\
\hline T0 afluente & nd & nd & nd & nd & nd & nd & nd \\
\hline T0 sub-superfície & nd & nd & nd & nd & nd & nd & nd \\
\hline T0 camada intermediária & nd & nd & nd & nd & nd & nd & nd \\
\hline T0 interface água-sedimento & nd & nd & nd & nd & nd & nd & nd \\
\hline T0 efluente & nd & nd & nd & nd & nd & nd & nd \\
\hline \multicolumn{8}{|l|}{ 24/01/2005 (14:00 h) } \\
\hline T1 afluente & nd & nd & nd & nd & nd & nd & nd \\
\hline T1 sub-superfície & nd & nd & nd & nd & nd & nd & nd \\
\hline T1 camada intermediária & nd & nd & nd & nd & nd & nd & nd \\
\hline T1 interface água-sedimento & nd & nd & nd & nd & nd & nd & nd \\
\hline T1 efluente & nd & nd & nd & nd & nd & nd & nd \\
\hline \multicolumn{8}{|l|}{ 24/01/2005 (20:00 h) } \\
\hline $\mathrm{T} 2$ afluente & nd & nd & nd & nd & nd & nd & nd \\
\hline T2 sub-superfície & nd & nd & nd & nd & nd & nd & nd \\
\hline T2 camada intermediária & nd & nd & nd & nd & nd & nd & nd \\
\hline T2 interface água-sedimento & nd & nd & nd & nd & nd & nd & nd \\
\hline $\mathrm{T} 2$ efluente & nd & nd & nd & nd & nd & nd & nd \\
\hline \multicolumn{8}{|l|}{ 25/01/2005 (02:00 h) } \\
\hline T3 afluente & nd & nd & nd & nd & nd & nd & nd \\
\hline T3 sub-superfície & nd & nd & nd & nd & nd & nd & nd \\
\hline T3 camada intermediária & nd & nd & nd & nd & nd & nd & nd \\
\hline T3 interface água-sedimento & 8,4 & nd & nd & nd & nd & nd & nd \\
\hline $\mathrm{T} 3$ efluente & 8,1 & nd & nd & nd & nd & nd & nd \\
\hline \multicolumn{8}{|l|}{ 25/01/2005 (08:00 h) } \\
\hline T4 afluente & nd & nd & nd & nd & nd & nd & nd \\
\hline T4 sub-superfície & nd & nd & nd & nd & nd & nd & nd \\
\hline T4 camada intermediária & nd & nd & nd & nd & nd & nd & nd \\
\hline T4 interface água-sedimento & nd & nd & nd & nd & nd & nd & nd \\
\hline T4 efluente & nd & nd & nd & nd & nd & nd & nd \\
\hline
\end{tabular}

nd: abaixo do limite de detecção

Valores mínimos detectáveis: ácido acético: $5,2 \mathrm{mg} / \mathrm{L}$; ácido propiônico: 4,8 mg/L; ácido butírico: 4,8 mg/L; ácido isovalérico: 4,4 mg/L; ácido valérico: 4,7 mg/L; ácido caproico: 4,6 mg/L 
Tabela B13: Dados obtidos na lagoa anaeróbia - Coleta no outono (abril 2005)

\begin{tabular}{|c|c|c|c|c|c|c|c|}
\hline $\begin{array}{l}\text { Locais de amostragem } \\
\text { (Cajati) }\end{array}$ & pH & $\begin{array}{l}\text { Temperatura } \\
\left({ }^{\circ} \mathrm{C}\right)\end{array}$ & $\begin{array}{c}\text { Oxigênio } \\
\text { dissolvido } \\
\text { (mg/L) }\end{array}$ & $\begin{array}{l}\text { Sulfato } \\
(\mathrm{mg} / \mathrm{L})\end{array}$ & $\begin{array}{l}\text { DQOf } \\
\text { (mg/L) }\end{array}$ & $\begin{array}{l}\text { DQOb } \\
\text { (mg/L) }\end{array}$ & $\begin{array}{c}\text { SSV } \\
(\mathrm{mg} / \mathrm{L})\end{array}$ \\
\hline \multicolumn{8}{|l|}{ 12/04/2005 (08:00 h) } \\
\hline T0 afluente & 7,2 & 27,4 & 0,9 & 36 & 36,8 & 175,8 & 87 \\
\hline T0 sub-superfície & 7,5 & 27,5 & 2,5 & 17 & 19 & 114 & 123 \\
\hline T0 camada intermediária & 7,1 & 26,4 & 0,06 & 20 & 4,7 & 236,1 & 60 \\
\hline T0 interface água-sedimento & 6,9 & 26,2 & 0,06 & 11 & 9,7 & 168,2 & 37 \\
\hline T0 efluente & 8,8 & 27,2 & 1,4 & 14 & 19,5 & 135,9 & 103 \\
\hline \multicolumn{8}{|l|}{ 12/04/2005 (14:00 h) } \\
\hline $\mathrm{T} 1$ afluente & 7,0 & 27,8 & 0,5 & 57 & 160,2 & 259,2 & 97 \\
\hline T1 sub-superfície & 9,1 & 35,1 & 8,2 & 12 & 46 & 109,5 & 67 \\
\hline T1 camada intermediária & 7,1 & 26,6 & 0,0 & 14 & 21 & 149,9 & 70 \\
\hline $\mathrm{T} 1$ interface água-sedimento & 7,0 & 26,2 & 0,0 & 0 & 26,9 & 177,1 & 93 \\
\hline T1 efluente & 6,9 & 27,2 & 0,5 & 0 & 4,7 & 174,3 & 0 \\
\hline \multicolumn{8}{|l|}{ 12/04/2005 (20:00 h) } \\
\hline $\mathrm{T} 2$ afluente & 6,9 & 27,9 & 0,5 & 64 & 147,9 & 350,9 & 207 \\
\hline $\mathrm{T} 2$ sub-superfície & 8,8 & 31,8 & 4,8 & 21 & 73 & 194,8 & 0 \\
\hline T2 camada intermediária & 7,1 & 26,7 & 0,04 & 17 & 96,5 & 188,9 & 0 \\
\hline $\mathrm{T} 2$ interface água sedimento & 6,8 & 26,2 & 0,07 & 13 & 96,5 & 137,8 & 0 \\
\hline $\mathrm{T} 2$ efluente & 7,1 & 28,3 & 0,4 & 5 & 95 & 123,8 & 30 \\
\hline \multicolumn{8}{|l|}{ 13/04/2005 (02:00 h) } \\
\hline T3 afluente & 6,8 & 27,9 & 1,8 & 34 & 145,4 & 268,6 & 0 \\
\hline T3 sub-superfície & 7,8 & 30,5 & 0,1 & 17 & 45 & 144,5 & 47 \\
\hline T3 camada intermediária & 7,1 & 27,6 & 0,04 & 15 & 51,6 & 148,1 & 117 \\
\hline $\mathrm{T} 3$ interface água-sedimento & 6,8 & 27,1 & 0,04 & 11 & 26,9 & 132,6 & 137 \\
\hline T3 efluente & 6,9 & 27,8 & 2,0 & 1 & 4,7 & 134,7 & 90 \\
\hline \multicolumn{8}{|l|}{ 13/04/2005 (08:00 h) } \\
\hline T4 afluente & 7,2 & 29,1 & 0,9 & 25 & 71,4 & 125,6 & 0 \\
\hline T4 sub-superfície & 7,5 & 29,2 & 1,1 & 13 & 68,9 & 134,7 & 83 \\
\hline T4 camada intermediária & 7,0 & 29,0 & 0,05 & 13 & 66,4 & 164,7 & 50 \\
\hline $\mathrm{T} 4$ interface água-sedimento & 6,9 & 28,4 & 0,06 & 12 & 31,9 & 111,6 & 57 \\
\hline T4 efluente & 7,2 & 28,6 & 2,1 & 1 & 44,2 & 132,9 & 40 \\
\hline
\end{tabular}


Tabela B14: Nutrientes totais e dissolvidos na lagoa anaeróbia - Coleta no outono (abril 2005)

\begin{tabular}{|c|c|c|c|c|c|c|c|}
\hline \multirow[b]{2}{*}{$\begin{array}{c}\text { Estações de amostragem } \\
\text { (Cajati) }\end{array}$} & \multicolumn{5}{|c|}{ Nutrientes dissolvidos } & \multicolumn{2}{|c|}{ Nutrientes totais } \\
\hline & $\begin{array}{l}\text { Nitrato } \\
\text { (mg/L) }\end{array}$ & $\begin{array}{l}\text { Nitrito } \\
(\mu \mathrm{g} / \mathrm{L})\end{array}$ & $\begin{array}{c}\text { Nitrogênio } \\
\text { amoniacal } \\
\text { (mg/L) }\end{array}$ & $\begin{array}{l}\text { PTD } \\
\text { (mg/L) }\end{array}$ & $\begin{array}{l}\text { Ortofosfato } \\
\text { (mg/L) }\end{array}$ & $\begin{array}{c}\text { Fósforo } \\
\text { total } \\
\text { (mg/L) }\end{array}$ & $\begin{array}{c}\text { NTK } \\
(\mathrm{mg} / \mathrm{L})\end{array}$ \\
\hline \multicolumn{8}{|l|}{ 12/04/2005 (08:00 h) } \\
\hline T0 afluente & 2,9 & 5,4 & 23,2 & 2,7 & 2,3 & 7,4 & 30,9 \\
\hline T0 sub-superfície & 2,9 & 2,3 & 11,2 & 1,7 & 1,03 & 2,8 & 21,9 \\
\hline T0 camada intermediária & 2,4 & 4,6 & 15,9 & 2,8 & 2,4 & 4,4 & 17,6 \\
\hline T0 interface água-sedimento & 2,7 & 3,1 & 19,2 & 3,04 & 2,7 & 3,2 & 33,4 \\
\hline T0 efluente & 2,8 & 4,0 & 10,8 & 2,7 & 1,9 & 3,4 & 18,7 \\
\hline \multicolumn{8}{|l|}{ 12/04/2005 (14:00 h) } \\
\hline $\mathrm{T} 1$ afluente & 2,5 & 15,5 & 29,8 & 3,5 & 3,6 & 4,5 & 39,9 \\
\hline T1 sub-superfície & 4,6 & 3,1 & 8,2 & 2,03 & 1,7 & 2,6 & 13,3 \\
\hline T1 camada intermediária & 2,1 & 4,6 & 14,4 & 2,7 & 2,9 & 1,9 & 24,2 \\
\hline T1 interface água-sedimento & 2,9 & 2,6 & 17,1 & 3,1 & 3,05 & 3,2 & 20,4 \\
\hline T1 efluente & 2,6 & 4,5 & 15,4 & 2,3 & 2,1 & 3,4 & 19,7 \\
\hline \multicolumn{7}{|l|}{ 12/04/2005 (20:00 h) } & 23,9 \\
\hline T2 sub-superfície & 2,5 & 4,3 & 8,1 & 1,8 & 1,6 & 3,9 & 13,8 \\
\hline T2 camada intermediária & 2,9 & 4,7 & 13,5 & 2,8 & 2,5 & 2,2 & 22,6 \\
\hline T2 interface água-sedimento & 3,2 & 3,6 & 15,1 & 2,7 & 2,6 & 8,8 & 21,8 \\
\hline T2 efluente & 2,6 & 4,5 & 9,6 & 2,7 & 2,2 & 4,9 & 19,7 \\
\hline \multicolumn{8}{|l|}{ 13/04/2005 (02:00 h) } \\
\hline $\mathrm{T} 3$ afluente & 3,4 & 7,2 & 21,9 & 2,9 & 2,7 & 3,6 & 33,5 \\
\hline T3 sub-superfície & 2,6 & 3,8 & 8,7 & 2,3 & 1,6 & 3,9 & 13,6 \\
\hline T3 camada intermediária & 2,9 & 4,8 & 11,4 & 2,9 & 2,3 & 3,9 & 15,2 \\
\hline T3 interface água-sedimento & 2,6 & 4,3 & 19,4 & 2,9 & 2,7 & 0,3 & 21,0 \\
\hline T3 efluente & 2,5 & 3,31 & 14,1 & 2,2 & 1,7 & 4,2 & 16,2 \\
\hline \multicolumn{8}{|l|}{ 13/04/2005 (08:00 h) } \\
\hline T4 afluente & 2,79 & 5,2 & 20,3 & 2,6 & 2,1 & 4,2 & 26,4 \\
\hline T4 sub-superfície & 2,58 & 4,4 & 10,9 & 2,6 & 1,9 & 4,9 & 19,9 \\
\hline T4 camada intermediária & 2,83 & 3,5 & 15,6 & 2,6 & 2,1 & 7,3 & 20,4 \\
\hline T4 interface água-sedimento & 2,73 & 3,5 & 15,04 & 2,8 & 2,6 & 2,7 & 21,9 \\
\hline T4 efluente & 2,52 & 3,6 & 11,8 & 2,9 & 2,2 & 2,5 & 18,4 \\
\hline
\end{tabular}


Tabela B15: Ácidos orgânicos na lagoa anaeróbia - Coleta no outono (abril 2005)

\begin{tabular}{|c|c|c|c|c|c|c|c|}
\hline $\begin{array}{c}\text { Estações de amostragem } \\
\text { (Cajati) }\end{array}$ & $\begin{array}{l}\text { Ácido } \\
\text { acético } \\
(\mathrm{mg} / \mathrm{L})\end{array}$ & $\begin{array}{c}\text { Ácido } \\
\text { propiônico } \\
\text { (mg/L) }\end{array}$ & $\begin{array}{c}\text { Ácido } \\
\text { isobutírico } \\
\text { (mg/L) }\end{array}$ & $\begin{array}{c}\text { Ácido } \\
\text { butírico } \\
\text { (mg/L) }\end{array}$ & $\begin{array}{c}\text { Ácido } \\
\text { isovalérico } \\
\text { (mg/L) }\end{array}$ & $\begin{array}{c}\text { Ácido } \\
\text { valérico } \\
(\mathrm{mg} / \mathrm{L})\end{array}$ & $\begin{array}{c}\text { Ácido } \\
\text { caproico } \\
\text { (mg/L) }\end{array}$ \\
\hline \multicolumn{8}{|l|}{ 12/04/2005 (08:00 h) } \\
\hline T0 afluente & 32,691 & 2,558 & nd & nd & nd & nd & nd \\
\hline T0 sub-superfície & 2,059 & nd & nd & nd & nd & nd & nd \\
\hline T0 camada intermediária & 31,219 & nd & nd & nd & nd & nd & nd \\
\hline T0 interface água-sedimento & 44,442 & nd & nd & nd & 0 & nd & nd \\
\hline T0 efluente & 8,957 & nd & nd & nd & nd & nd & nd \\
\hline \multicolumn{8}{|l|}{ 12/04/2005 (14:00 h) } \\
\hline T1 afluente & nd & nd & nd & nd & nd & nd & nd \\
\hline T1 sub-superfície & nd & nd & nd & nd & nd & nd & nd \\
\hline T1 camada intermediária & nd & nd & nd & nd & nd & nd & nd \\
\hline T1 interface água-sedimento & nd & nd & nd & nd & nd & nd & nd \\
\hline T1 efluente & nd & nd & nd & nd & nd & nd & nd \\
\hline \multicolumn{8}{|l|}{ 12/04/2005 (20:00 h) } \\
\hline $\mathrm{T} 2$ afluente & 49,501 & 6,76 & nd & nd & nd & nd & nd \\
\hline T2 sub-superfície & nd & nd & nd & nd & nd & nd & nd \\
\hline T2 camada intermediária & 8,91 & nd & nd & nd & nd & nd & nd \\
\hline T2 interface água-sedimento & 35,9 & nd & nd & nd & nd & nd & nd \\
\hline T2 efluente & 10,58 & nd & nd & nd & nd & nd & nd \\
\hline \multicolumn{8}{|l|}{ 13/04/2005 (02:00 h) } \\
\hline T3 afluente & nd & nd & nd & nd & nd & nd & nd \\
\hline T3 sub-superfície & nd & nd & nd & nd & nd & nd & nd \\
\hline T3 camada intermediária & nd & nd & nd & nd & nd & nd & nd \\
\hline T3 interface água-sedimento & nd & nd & nd & nd & nd & nd & nd \\
\hline T3 efluente & nd & nd & nd & nd & nd & nd & nd \\
\hline \multicolumn{8}{|l|}{ 13/04/2005 (08:00 h) } \\
\hline T4 afluente & 39,05 & 6,28 & nd & nd & nd & nd & nd \\
\hline T4 sub-superfície & 3,8 & nd & nd & nd & nd & nd & nd \\
\hline T4 camada intermediária & 24,02 & nd & nd & nd & 0 & nd & nd \\
\hline T4 interface água-sedimento & 27,56 & nd & nd & nd & nd & nd & nd \\
\hline T4 efluente & 15,07 & nd & nd & nd & nd & nd & nd \\
\hline
\end{tabular}

nd: abaixo do limite de detecção

Valores mínimos detectáveis: ácido acético: $4,8 \mathrm{mg} / \mathrm{L}$; ácido propiônico: $3,2 \mathrm{mg} / \mathrm{L}$; ácido butírico: $3,8 \mathrm{mg} / \mathrm{L}$; ácido isovalérico:

$1,9 \mathrm{mg} / \mathrm{L}$; ácido valérico: $2,4 \mathrm{mg} / \mathrm{L}$; ácido caproico: $1,9 \mathrm{mg} / \mathrm{L}$ 
Tabela B16: Dados obtidos na lagoa facultativa - Coleta no outono (abril 2005)

\begin{tabular}{|c|c|c|c|c|c|c|c|}
\hline $\begin{array}{c}\text { Estações de amostragem } \\
\text { (Cajati) }\end{array}$ & pH & $\begin{array}{l}\text { Temperatura } \\
\quad\left({ }^{\circ} \mathrm{C}\right)\end{array}$ & $\begin{array}{l}\text { Oxigênio } \\
\text { dissolvido } \\
\text { (mg/L) }\end{array}$ & $\begin{array}{l}\text { Sulfato } \\
(\mathrm{mg} / \mathrm{L})\end{array}$ & $\begin{array}{l}\text { DQOf } \\
\text { (mg/L) }\end{array}$ & $\begin{array}{l}\text { DQOb } \\
\text { (mg/L) }\end{array}$ & $\begin{array}{c}\text { SSV } \\
(\mathrm{mg} / \mathrm{L})\end{array}$ \\
\hline \multicolumn{8}{|l|}{ 12/04/2005 (08:00 h) } \\
\hline T0 afluente & 8,8 & 27,2 & 1,4 & 14 & 19,5 & 135,9 & 103 \\
\hline T0 sub-superfície & 8,9 & 28,3 & 2,5 & 1 & 75,4 & 126,5 & 27 \\
\hline T0 camada intermediária & 8,7 & 27,7 & 0,07 & 0 & 31,9 & 113,1 & 040 \\
\hline $\mathrm{T} 0$ interface água-sedimento & 7,7 & 26,5 & 0,04 & 9 & 48 & 118,9 & 23 \\
\hline T0 efluente & 7,7 & 27,8 & 1,8 & 1 & 46 & 107,7 & 57 \\
\hline \multicolumn{8}{|l|}{ 12/04/2005 (14:00 h) } \\
\hline T1 afluente & 6,9 & 27,2 & 0,5 & 0 & 4,7 & 174,3 & 0 \\
\hline T1 sub-superfície & 9,9 & 34,3 & 7,2 & 1 & 46 & 108,2 & 0 \\
\hline T1 camada intermediária & 9,3 & 27,5 & 1,1 & 1 & 46 & 107 & 3 \\
\hline T1 interface água-sedimento & 8,2 & 26,5 & 0,1 & 4 & 82 & 131,7 & 47 \\
\hline T1 efluente & 8,6 & 32,4 & 3,5 & 1 & 39 & 173,7 & 47 \\
\hline \multicolumn{8}{|l|}{ 12/04/2005 (20:00 h) } \\
\hline $\mathrm{T} 2$ afluente & 7,1 & 28,3 & 0,4 & 5 & 25 & 123,8 & 30 \\
\hline T2 sub-superfície & 9,5 & 31,4 & 5,8 & 0 & 75 & 128,7 & 67 \\
\hline T2 camada intermediária & 9,3 & 27,0 & 0,1 & 1 & 52 & 160,6 & 13 \\
\hline T2 interface água-sedimento & 7,6 & 25,9 & 0,03 & 0 & 51 & 157,6 & 27 \\
\hline $\mathrm{T} 2$ efluente & 8,0 & 28,8 & 2,5 & 3 & 58 & 147,5 & 73 \\
\hline \multicolumn{8}{|l|}{ 13/04/2005 (02:00 h) } \\
\hline T3 afluente & 6,9 & 27,8 & 2,03 & 1 & 4,7 & 134,7 & 90 \\
\hline T3 sub-superfície & 8,3 & 30,6 & 2,3 & 3 & 24 & 121,3 & 53 \\
\hline T3 camada intermediária & 8,1 & 28,6 & 0,07 & 0 & 2,3 & 146,9 & 67 \\
\hline T3 interface água-sedimento & 7,4 & 27,8 & 0,03 & 0 & 59 & 148,9 & 53 \\
\hline $\mathrm{T} 3$ efluente & 7,7 & 28,6 & 1,6 & 0 & 24 & 100,2 & 77 \\
\hline \multicolumn{8}{|l|}{ 13/04/2005 (08:00 h) } \\
\hline T4 afluente & 7,2 & 28,6 & 2,1 & 1 & 44,2 & 132,9 & 40 \\
\hline T4 sub-superfície & 8,5 & 29,8 & 1,4 & 2 & 24,5 & 124,1 & 20 \\
\hline T4 camada intermediária & 8,4 & 29,9 & 0,2 & 2 & 29,4 & 226,1 & 70 \\
\hline T4 interface água-sedimento & 7,8 & 28,8 & 0,04 & 2 & 34,3 & 194,7 & 0 \\
\hline T4 efluente & 7,9 & 29,8 & 1,7 & 1 & 36,8 & 98,5 & 0 \\
\hline
\end{tabular}


Tabela B17: Nutrientes totais e dissolvidos na lagoa facultativa - Coleta no outono (abril 2005)

\begin{tabular}{|c|c|c|c|c|c|c|c|}
\hline \multirow{2}{*}{$\begin{array}{c}\text { Estações de amostragem } \\
\text { (Cajati) }\end{array}$} & \multicolumn{5}{|c|}{ Nutrientes dissolvidos } & \multicolumn{2}{|c|}{ Nutrientes totais } \\
\hline & $\begin{array}{l}\text { Nitrato } \\
(\mathrm{mg} / \mathrm{L})\end{array}$ & $\begin{array}{l}\text { Nitrito } \\
(\mu \mathrm{g} / \mathrm{L})\end{array}$ & $\begin{array}{c}\text { Nitrogênio } \\
\text { amoniacal } \\
(\mathrm{mg} / \mathrm{L})\end{array}$ & $\begin{array}{c}\text { PTD } \\
(\mathrm{mg} / \mathrm{L})\end{array}$ & $\begin{array}{l}\text { Ortofosfato } \\
\text { (mg/L) }\end{array}$ & $\begin{array}{c}\text { Fósforo } \\
\text { total } \\
(\mathrm{mg} / \mathrm{L})\end{array}$ & $\begin{array}{c}\text { NTK } \\
(\mathrm{mg} / \mathrm{L})\end{array}$ \\
\hline $\begin{array}{l}\text { 12/04/2005 }(\mathbf{0 8 : 0 0 ~ h )} \\
\text { T0 afluente }\end{array}$ & 2,8 & 4,02 & 10,8 & 2,7 & 1,9 & 3,4 & 18,7 \\
\hline T0 sub-superfície & 2,7 & 6,6 & 1,9 & 1,4 & 1,1 & 0,9 & 7,3 \\
\hline T0 camada intermediária & 2,3 & 5,9 & 2,2 & 1,4 & 0,9 & 1,4 & 9,9 \\
\hline T0 interface água-sedimento & 2,2 & 4,9 & 4,3 & 1,7 & 0,9 & 1,7 & 8,4 \\
\hline T0 efluente & 2,3 & 7,8 & 2,9 & 1,5 & 0,9 & 3,1 & 8,9 \\
\hline $\begin{array}{l}\text { 12/04/2005 }(\mathbf{1 4 : 0 0 ~ h )} \\
\mathrm{T} 1 \text { afluente }\end{array}$ & 2,6 & 4,5 & 15,4 & 2,3 & 2,1 & 3,4 & 19,7 \\
\hline T1 sub-superfície & 2,4 & 7,4 & 0,3 & 1,1 & 0,8 & 3,5 & 8,1 \\
\hline T1 camada intermediária & 2,4 & 7,4 & 2,7 & 1,3 & 0,9 & 6,4 & 6,5 \\
\hline T1 interface água-sedimento & 2,3 & 6,2 & 4,7 & 1,7 & 0,8 & 2,5 & 9,2 \\
\hline T1 efluente & 2,3 & 6,3 & 2,8 & 1,5 & 1,1 & 2,8 & 7,8 \\
\hline $\begin{array}{l}\text { 12/04/2005 }(\mathbf{2 0 : 0 0 ~ h )} \\
\mathrm{T} 2 \text { afluente }\end{array}$ & 2,6 & 4,5 & 9,6 & 2,7 & 2,2 & 4,9 & 19,7 \\
\hline T2 sub-superfície & 2,2 & 10,1 & 1,6 & 1,3 & 0,7 & 2,2 & 8,9 \\
\hline T2 camada intermediária & 2,3 & 9,8 & 2,1 & 1,6 & 0,8 & 4,2 & 15,7 \\
\hline T2 interface água-sedimento & 2,4 & 5,3 & 5,3 & 2,0 & 1,8 & 0,9 & 10,4 \\
\hline $\mathrm{T} 2$ efluente & 2,5 & 14,02 & 4,1 & 1,3 & 0,9 & 0,9 & 8,4 \\
\hline 13/04/2005 (02:00 h) & & & & & & & \\
\hline T3 afluente & 2,5 & 3,3 & 14,1 & 2,2 & 1,7 & 4,2 & 16,2 \\
\hline T3 sub-superfície & 2,9 & 7,0 & 3,9 & 2,7 & 2,4 & 1,4 & 6,8 \\
\hline T3 camada intermediária & 2,3 & 8,9 & 2,9 & 1,6 & 0,9 & 5,6 & 12,51 \\
\hline T3 interface água-sedimento & 2,3 & 7,8 & 5,2 & 1,6 & 0,9 & 3,7 & 10,2 \\
\hline T3 efluente & 2,2 & 18,7 & 3,8 & 1,3 & 0,8 & 1,7 & 7,6 \\
\hline 13/04/2005 (08:00 h) & & & & & & & \\
\hline T4 afluente & 2,5 & 3,6 & 11,8 & 2,9 & 2,2 & 2,5 & 18,4 \\
\hline T4 sub-superfície & 2,1 & 3,2 & 2,9 & 1,1 & 0,6 & 0,7 & 7,2 \\
\hline T4 camada intermediária & 2,1 & 3,2 & 2,9 & 1,5 & 0,8 & 1,6 & 8,3 \\
\hline T4 interface água-sedimento & 1,7 & 2,9 & 3,4 & 1,2 & 0,8 & 1,6 & 7,8 \\
\hline T4 efluente & 2,2 & 8,6 & 2,6 & 1,5 & 0,9 & 0,5 & 9,6 \\
\hline
\end{tabular}


Tabela B18: Ácidos orgânicos na lagoa facultativa - Coleta no outono (abril 2005)

\begin{tabular}{|c|c|c|c|c|c|c|c|}
\hline $\begin{array}{c}\text { Estações de amostragem } \\
\text { (Cajati) }\end{array}$ & $\begin{array}{l}\text { Ácido } \\
\text { acético } \\
\text { (mg/L) }\end{array}$ & $\begin{array}{c}\text { Ácido } \\
\text { propiônico } \\
\text { (mg/L) }\end{array}$ & $\begin{array}{c}\text { Ácido } \\
\text { isobutírico } \\
(\mathrm{mg} / \mathrm{L})\end{array}$ & $\begin{array}{c}\text { Ácido } \\
\text { butírico } \\
\text { (mg/L) }\end{array}$ & $\begin{array}{c}\text { Ácido } \\
\text { isovalérico } \\
\text { (mg/L) }\end{array}$ & $\begin{array}{c}\text { Ácido } \\
\text { valérico } \\
\text { (mg/L) }\end{array}$ & $\begin{array}{c}\text { Ácido } \\
\text { caproico } \\
\text { (mg/L) }\end{array}$ \\
\hline \multicolumn{8}{|l|}{ 12/04/2005 (08:00 h) } \\
\hline T0 afluente & 8,9 & nd & nd & nd & nd & nd & nd \\
\hline T0 sub-superfície & nd & nd & nd & nd & nd & nd & nd \\
\hline T0 camada intermediária & nd & nd & nd & nd & nd & nd & nd \\
\hline T0 interface água-sedimento & nd & nd & nd & nd & nd & nd & nd \\
\hline T0 efluente & nd & nd & nd & nd & nd & nd & nd \\
\hline \multicolumn{8}{|l|}{ 12/04/2005 (14:00 h) } \\
\hline T1 afluente & nd & nd & nd & nd & nd & nd & nd \\
\hline T1 sub-superfície & nd & nd & nd & nd & nd & nd & nd \\
\hline T1 camada intermediária & nd & nd & nd & nd & nd & nd & nd \\
\hline T1 interface água-sedimento & nd & nd & nd & nd & nd & nd & nd \\
\hline T1 efluente & nd & nd & nd & nd & nd & nd & nd \\
\hline \multicolumn{8}{|l|}{ 12/04/2005 (20:00 h) } \\
\hline $\mathrm{T} 2$ afluente & 10,6 & nd & nd & nd & nd & nd & nd \\
\hline T2 sub-superfície & nd & nd & nd & nd & nd & nd & nd \\
\hline T2 camada intermediária & nd & nd & nd & nd & nd & nd & nd \\
\hline T2 interface água-sedimento & nd & nd & nd & nd & nd & nd & nd \\
\hline $\mathrm{T} 2$ efluente & nd & nd & nd & nd & nd & nd & nd \\
\hline \multicolumn{8}{|l|}{ 13/04/2005 (02:00 h) } \\
\hline $\mathrm{T} 3$ afluente & nd & nd & nd & nd & nd & nd & nd \\
\hline T3 sub-superfície & nd & nd & nd & nd & nd & nd & nd \\
\hline T3 camada intermediária & nd & nd & nd & nd & nd & nd & nd \\
\hline T3 interface água-sedimento & nd & nd & nd & nd & nd & nd & nd \\
\hline T3 efluente & nd & nd & nd & nd & nd & nd & nd \\
\hline \multicolumn{8}{|l|}{ 13/04/2005 (08:00 h) } \\
\hline T4 afluente & 15,1 & nd & nd & nd & nd & nd & nd \\
\hline T4 sub-superfície & nd & nd & nd & nd & nd & nd & nd \\
\hline T4 camada intermediária & nd & nd & nd & nd & nd & nd & nd \\
\hline T4 interface água-sedimento & nd & nd & nd & nd & nd & nd & nd \\
\hline T4 efluente & nd & nd & nd & nd & nd & nd & nd \\
\hline
\end{tabular}

nd: abaixo do limite de detecção

Valores mínimos detectáveis: ácido acético: $4,8 \mathrm{mg} / \mathrm{L}$; ácido propiônico: $3,2 \mathrm{mg} / \mathrm{L}$; ácido butírico: $3,8 \mathrm{mg} / \mathrm{L}$; ácido isovalérico: $1,9 \mathrm{mg} / \mathrm{L}$; ácido valérico: $2,4 \mathrm{mg} / \mathrm{L}$; ácido caproico: $1,9 \mathrm{mg} / \mathrm{L}$ 
Tabela B19: Dados obtidos na lagoa anaeróbia - Coleta no inverno (julho 2005)

\begin{tabular}{|c|c|c|c|c|c|c|c|}
\hline $\begin{array}{c}\text { Estações de amostragem } \\
\text { (Cajati) }\end{array}$ & pH & $\begin{array}{l}\text { Temperatura } \\
\quad\left({ }^{\circ} \mathrm{C}\right)\end{array}$ & $\begin{array}{r}\text { Oxigênio } \\
\text { dissolvido } \\
\text { (mg/L) }\end{array}$ & $\begin{array}{l}\text { Sulfato } \\
(\mathrm{mg} / \mathrm{L})\end{array}$ & $\begin{array}{l}\text { DQOf } \\
(\mathrm{mg} / \mathrm{L})\end{array}$ & $\begin{array}{l}\text { DQOb } \\
(\mathrm{mg} / \mathrm{L})\end{array}$ & $\begin{array}{c}\text { SSV } \\
(\mathrm{mg} / \mathrm{L})\end{array}$ \\
\hline \multicolumn{8}{|l|}{ 14/07/2005 (08:00 h) } \\
\hline T0 sub-superfície & 8,1 & 19,8 & 1,2 & 9 & 7,2 & 61,3 & 0 \\
\hline T0 camada intermediária & 7,8 & 19,7 & 1,3 & 19 & 24,5 & 153,2 & 100 \\
\hline T0 interface água-sedimento & 7,2 & 19,8 & 1,7 & 4 & 0 & 83,5 & 13 \\
\hline \multicolumn{8}{|l|}{ 14/07/2005 (14:00 h) } \\
\hline T1 sub-superfície & 9,4 & 26,9 & 8,2 & 4 & 0 & 99,7 & 73 \\
\hline $\mathrm{T} 1$ camada intermediária & 8,9 & 19,6 & 1,6 & 18 & 29,4 & 140,6 & 120 \\
\hline $\mathrm{T} 1$ interface água-sedimento & 8,2 & 19,6 & 0,9 & 14 & 18,3 & 60,3 & 113 \\
\hline \multicolumn{8}{|l|}{ 14/07/2005 (20:00 h) } \\
\hline T2 sub-superfície & 9,9 & 24,1 & 6,4 & 4 & 2,2 & 150,5 & 57 \\
\hline T2 camada intermediária & 9,2 & 19,6 & 1,6 & 2 & 10,9 & 88,7 & 60 \\
\hline T2 interface água-sedimento & 8,5 & 19,6 & 0,7 & 7 & 4,7 & 54,1 & 80 \\
\hline \multicolumn{8}{|l|}{ 15/07/2005 (02:00 h) } \\
\hline T3 sub-superfície & 8,6 & 20,5 & 6,3 & 51 & 19,5 & 213 & 73 \\
\hline T3 camada intermediária & 8,3 & 19,6 & 0,3 & 43 & 18,3 & 251,7 & 53 \\
\hline T3 interface água-sedimento & 7,9 & 19,64 & 0,1 & 23 & 18,3 & 248 & 37 \\
\hline \multicolumn{8}{|l|}{ 15/07/2005 (08:00 h) } \\
\hline T4 sub-superfície & 8,9 & 19,4 & 1,8 & 13 & 8,4 & 150 & 0 \\
\hline T4 camada intermediária & 8,6 & 19,5 & 1,4 & 12 & 107,1 & 170,1 & 107 \\
\hline T4 interface água-sedimento & 7,7 & 19,5 & 1,5 & 12 & 13,4 & 151,2 & 0 \\
\hline
\end{tabular}


Tabela B20: Nutrientes totais e dissolvidos na lagoa anaeróbia - Coleta no inverno (julho 2005)

\begin{tabular}{|c|c|c|c|c|c|c|c|}
\hline \multirow{2}{*}{$\begin{array}{c}\text { Estações de amostragem } \\
\text { (Cajati) }\end{array}$} & \multicolumn{5}{|c|}{ Nutrientes dissolvidos } & \multicolumn{2}{|c|}{ Nutrientes totais } \\
\hline & $\begin{array}{l}\text { Nitrato } \\
(\mathrm{mg} / \mathrm{L})\end{array}$ & $\begin{array}{c}\text { Nitrito } \\
(\mu \mathrm{g} / \mathrm{L})\end{array}$ & $\begin{array}{l}\text { Nitrogênio } \\
\text { amoniacal } \\
(\mathrm{mg} / \mathrm{L})\end{array}$ & $\begin{array}{c}\text { PTD } \\
(\mathrm{mg} / \mathrm{L})\end{array}$ & $\begin{array}{l}\text { Ortofosfato } \\
(\mathrm{mg} / \mathrm{L})\end{array}$ & $\begin{array}{c}\text { Fósforo } \\
\text { total } \\
(\mathrm{mg} / \mathrm{L})\end{array}$ & $\begin{array}{c}\text { NTK } \\
(\mathrm{mg} / \mathrm{L})\end{array}$ \\
\hline $\begin{array}{l}\text { 14/07/2005 }(\mathbf{0 8 : 0 0 ~ h )} \\
\text { T0 sub-superfície }\end{array}$ & 1,9 & 3,1 & 16,7 & 6,6 & 5,3 & 3,7 & 25,5 \\
\hline T0 camada intermediária & 2,0 & 2,7 & 15,9 & 3 & 3,4 & 2,8 & 24,6 \\
\hline T0 interface água-sedimento & 1,7 & 2,2 & 16,6 & 4,7 & 2,9 & 3,4 & 22,2 \\
\hline \multicolumn{8}{|l|}{ 14/07/2005 (14:00 h) } \\
\hline T1 sub-superfície & 1,5 & 2,2 & 12,6 & 3,9 & 1,4 & 3,01 & 20,4 \\
\hline T1 camada intermediária & 1,6 & 1,9 & 14,7 & 5,2 & 2,3 & 3,9 & 23,3 \\
\hline T1 interface água-sedimento & 1,7 & 1,9 & 16,1 & 11,1 & 2,4 & 3,4 & 23,3 \\
\hline \multicolumn{8}{|l|}{ 14/07/2005 (20:00 h) } \\
\hline $\mathrm{T} 2$ sub-superfície & 1,7 & 2,2 & 13,4 & 5,4 & 3,1 & 3,2 & 20,3 \\
\hline T2 camada intermediária & 1,7 & 2,5 & 16,4 & 4,9 & 2,8 & 3,6 & 20,4 \\
\hline T2 interface água-sedimento & 1,6 & 1,8 & 18,4 & 5,8 & 3,4 & 5 & 23,9 \\
\hline \multicolumn{8}{|l|}{ 15/07/2005 (02:00 h) } \\
\hline T3 sub-superfície & 1,9 & 2,9 & 13,2 & 4,2 & 2,4 & 4,2 & 21,5 \\
\hline T3 camada intermediária & 1,8 & 2,1 & 15,9 & 6,2 & 3,4 & 4,8 & 23,1 \\
\hline T3 interface água-sedimento & 1,8 & 2,6 & 17,2 & 3,8 & 2,5 & 4,3 & 24,6 \\
\hline \multicolumn{8}{|l|}{ 15/07/2005 (08:00 h) } \\
\hline T4 sub-superfície & 1,9 & 2,2 & 16,8 & 4,2 & 2,7 & 5,2 & 25,8 \\
\hline T4 camada intermediária & 2,04 & 3,3 & 17,7 & 5,5 & 2,7 & 5,3 & 22,0 \\
\hline T4 interface água-sedimento & 1,9 & 2,6 & 17,5 & 4,01 & 4,1 & 5,2 & 19,4 \\
\hline
\end{tabular}


Tabela B21: Ácidos orgânicos na lagoa anaeróbia - Coleta no inverno (julho 2005)

\begin{tabular}{|c|c|c|c|c|c|c|c|}
\hline $\begin{array}{c}\text { Estações de amostragem } \\
\text { (Cajati) }\end{array}$ & $\begin{array}{l}\text { Ácido } \\
\text { acético } \\
\text { (mg/L) }\end{array}$ & $\begin{array}{c}\text { Ácido } \\
\text { propiônico } \\
\text { (mg/L) }\end{array}$ & $\begin{array}{l}\text { Ácido } \\
\text { isobutírico } \\
\text { (mg/L) }\end{array}$ & $\begin{array}{c}\text { Ácido } \\
\text { butírico } \\
\text { (mg/L) }\end{array}$ & $\begin{array}{c}\text { Ácido } \\
\text { isovalérico } \\
\text { (mg/L) }\end{array}$ & $\begin{array}{c}\text { Ácido } \\
\text { valérico } \\
\text { (mg/L) }\end{array}$ & $\begin{array}{c}\text { Ácido } \\
\text { caproico } \\
\text { (mg/L) }\end{array}$ \\
\hline \multicolumn{8}{|l|}{ 12/04/2005 (08:00 h) } \\
\hline T0 sub-superfície & 3,8 & nd & nd & nd & nd & nd & nd \\
\hline T0 camada intermediária & nd & nd & nd & nd & nd & nd & nd \\
\hline $\mathrm{T} 0$ interface água-sedimento & nd & nd & nd & nd & nd & nd & nd \\
\hline \multicolumn{8}{|l|}{ 12/04/2005 (14:00 h) } \\
\hline T1 sub-superfície & nd & nd & nd & nd & nd & nd & nd \\
\hline T1 camada intermediária & nd & nd & nd & nd & nd & nd & nd \\
\hline $\mathrm{T} 1$ interface água-sedimento & nd & nd & nd & nd & nd & nd & nd \\
\hline \multicolumn{8}{|l|}{ 12/04/2005 (20:00 h) } \\
\hline T2 sub-superfície & nd & nd & nd & nd & nd & nd & nd \\
\hline T2 camada intermediária & nd & nd & nd & nd & nd & nd & nd \\
\hline $\mathrm{T} 2$ interface água-sedimento & nd & nd & nd & nd & nd & nd & nd \\
\hline \multicolumn{8}{|l|}{ 13/04/2005 (02:00 h) } \\
\hline T3 sub-superficie & nd & nd & nd & nd & nd & nd & nd \\
\hline $\mathrm{T} 3$ camada intermediária & nd & nd & nd & nd & nd & nd & nd \\
\hline $\mathrm{T} 3$ interface água-sedimento & nd & nd & nd & nd & nd & nd & nd \\
\hline \multicolumn{8}{|l|}{ 13/04/2005 (08:00 h) } \\
\hline T4 sub-superfície & nd & nd & nd & nd & nd & nd & nd \\
\hline T4 camada intermediária & nd & nd & nd & nd & nd & nd & nd \\
\hline T4 interface água-sedimento & 4,4 & nd & nd & 0 & nd & nd & nd \\
\hline
\end{tabular}

nd: abaixo do limite de detecção

Valores mínimos detectáveis: ácido acético: $3,1 \mathrm{mg} / \mathrm{L}$; ácido propiônico: $3,2 \mathrm{mg} / \mathrm{L}$; ácido butírico: $0,96 \mathrm{mg} / \mathrm{L}$; ácido isovalérico: $0,47 \mathrm{mg} / \mathrm{L}$; ácido valérico: $0,6 \mathrm{mg} / \mathrm{L}$; ácido caproico: $0,48 \mathrm{mg} / \mathrm{L}$ 
Tabela B22: Dados obtidos na lagoa facultativa - Coleta no inverno (julho 2005)

\begin{tabular}{|c|c|c|c|c|c|c|c|}
\hline $\begin{array}{c}\text { Estações de amostragem } \\
\text { (Cajati) }\end{array}$ & pH & $\begin{array}{l}\text { Temperatura } \\
\quad\left({ }^{\circ} \mathrm{C}\right)\end{array}$ & $\begin{array}{c}\text { Oxigênio } \\
\text { dissolvido } \\
\text { (mg/L) }\end{array}$ & $\begin{array}{l}\text { Sulfato } \\
(\mathrm{mg} / \mathrm{L})\end{array}$ & $\begin{array}{l}\text { DQOf } \\
\text { (mg/L) }\end{array}$ & $\begin{array}{l}\text { DQOb } \\
(\mathrm{mg} / \mathrm{L})\end{array}$ & $\begin{array}{l}\text { SSV } \\
(\mathrm{mg} / \mathrm{L})\end{array}$ \\
\hline \multicolumn{8}{|l|}{ 14/07/2005 (08:00 h) } \\
\hline T0 sub-superfície & 8,1 & 19,5 & 2,8 & 16 & 14,6 & 63,1 & 73 \\
\hline T0 camada intermediária & 8,4 & 19,5 & 2,5 & 3 & 41,7 & 153,3 & 123 \\
\hline T0 interface água-sedimento & 8,4 & 19,6 & 1,4 & 1 & 39,3 & 93 & 93 \\
\hline T0 efluente & 9 & 18,1 & 3,8 & 0 & 49,1 & 148,7 & 0 \\
\hline \multicolumn{8}{|l|}{ 14/07/2005 (14:00 h) } \\
\hline T1 sub-superfície & 10,3 & 20,1 & 5,7 & 1 & 25,7 & 69 & 0 \\
\hline T1 camada intermediária & 10,1 & 19,8 & 4,4 & 3 & 55,3 & 93,9 & 117 \\
\hline $\mathrm{T} 1$ interface água-sedimento & 10,0 & 19,6 & 2,9 & 1 & 42,9 & 154,4 & 153 \\
\hline T1 efluente & 9,9 & 22,3 & 5,2 & 0 & 39,3 & 145 & 90 \\
\hline \multicolumn{8}{|l|}{ 14/07/2005 (20:00 h) } \\
\hline T2 sub-superfície & 10,6 & 23,3 & 7,7 & 0 & 56,5 & 131,5 & 157 \\
\hline T2 camada intermediária & 10,2 & 19,8 & 4,1 & 1 & 40,5 & 133,3 & 83 \\
\hline T2 interface água-sedimento & 10,1 & 19,6 & 1,03 & 0 & 45,4 & 140,1 & 93 \\
\hline $\mathrm{T} 2$ efluente & 9,9 & 19,2 & 5,1 & 4 & 49,1 & 156 & 93 \\
\hline \multicolumn{8}{|l|}{ 15/07/2005 (02:00 h) } \\
\hline T3 sub-superfície & 10,2 & 20,8 & 6,2 & 2 & 44,2 & 306,6 & 0 \\
\hline T3 camada intermediária & 10,0 & 19,8 & 3,01 & 0 & 55,3 & 280 & 80 \\
\hline T3 interface água-sedimento & 9,8 & 19,6 & 0,5 & 1 & 49,1 & 283,6 & 60 \\
\hline $\mathrm{T} 3$ efluente & 9,3 & 18,5 & 2,3 & 2 & 36,8 & 300,4 & 50 \\
\hline \multicolumn{8}{|l|}{ 15/07/2005 (08:00 h) } \\
\hline T4 sub-superfície & 9,0 & 19,3 & 2,9 & 2 & 30,6 & 230,4 & 77 \\
\hline T4 camada intermediária & 9,4 & 19,4 & 2,6 & 1 & 46,7 & 185,6 & 140 \\
\hline T4 interface água-sedimento & 9,5 & 19,4 & 2,5 & 1 & 50,4 & 199,6 & 140 \\
\hline T4 efluente & 9,1 & 17,7 & 3,7 & 0 & 18,3 & 182,5 & 63 \\
\hline
\end{tabular}


Tabela B23: Nutrientes totais e dissolvidos na lagoa facultativa - Coleta no inverno (julho 2005)

\begin{tabular}{|c|c|c|c|c|c|c|c|}
\hline \multirow[b]{2}{*}{$\begin{array}{c}\text { Estações de amostragem } \\
\text { (Cajati) }\end{array}$} & \multicolumn{5}{|c|}{ Nutrientes dissolvidos } & \multicolumn{2}{|c|}{ Nutrientes totais } \\
\hline & $\begin{array}{l}\text { Nitrato } \\
(\mathrm{mg} / \mathrm{L})\end{array}$ & $\begin{array}{l}\text { Nitrito } \\
(\mu \mathrm{g} / \mathrm{L})\end{array}$ & $\begin{array}{l}\text { Nitrogênio } \\
\text { amoniacal } \\
(\mathrm{mg} / \mathrm{L})\end{array}$ & $\begin{array}{c}\text { PTD } \\
(\mathrm{mg} / \mathrm{L})\end{array}$ & $\begin{array}{l}\text { Ortofosfato } \\
\text { (mg/L) }\end{array}$ & $\begin{array}{c}\text { Fósforo } \\
\text { total } \\
\text { (mg/L) }\end{array}$ & $\begin{array}{c}\text { NTK } \\
(\mathrm{mg} / \mathrm{L})\end{array}$ \\
\hline \multicolumn{8}{|l|}{ 14/07/2005 (08:00 h) } \\
\hline T0 sub-superfície & 1,52 & 2,3 & 0,4 & 3,6 & 1,9 & 2,9 & 14 \\
\hline T0 camada intermediária & 1,33 & 1,7 & 0,4 & 3,2 & 1,2 & 3,9 & 9,2 \\
\hline T0 interface água-sedimento & 1,4 & 1,9 & 0,8 & 1,9 & 21,1 & 4,4 & 7,6 \\
\hline T0 efluente & 1,2 & 2,5 & 0,8 & 3,3 & 0,9 & 3,2 & 9,3 \\
\hline \multicolumn{8}{|l|}{ 14/07/2005 (14:00 h) } \\
\hline T1 sub-superfície & 1,5 & 1,5 & 0,7 & 3,8 & 0,3 & 2,1 & 9,6 \\
\hline T1 camada intermediária & 1,3 & 1,5 & 1,01 & 4,01 & 0,5 & 2,6 & 10,5 \\
\hline T1 interface água-sedimento & 1,4 & 3,1 & 0,3 & 3,5 & 1,6 & 5,5 & 9,2 \\
\hline T1 efluente & 1,3 & 1,1 & 0,2 & 2,2 & 0,2 & 3 & 7,3 \\
\hline \multicolumn{8}{|l|}{ 14/07/2005 (20:00 h) } \\
\hline T2 sub-superfície & 1,6 & 1,6 & 0,2 & 0,5 & 0,5 & 1,2 & 7 \\
\hline T2 camada intermediária & 1,2 & 5,5 & 0,4 & 2,8 & 0,5 & 4,3 & 9,8 \\
\hline T2 interface água-sedimento & 1,4 & 1,6 & 0,5 & 4,8 & 1,8 & 2,5 & 8,1 \\
\hline $\mathrm{T} 2$ efluente & 1,3 & 1,9 & 0,4 & 3,1 & 1,2 & 3,4 & 10,4 \\
\hline \multicolumn{8}{|l|}{ 15/07/2005 (02:00 h) } \\
\hline T3 sub-superfície & 1,5 & 1,9 & 0,3 & 2,9 & 0,4 & 2,9 & 10,3 \\
\hline T3 camada intermediária & 1,5 & 1,8 & 0,3 & 1,1 & 1,1 & 4,1 & 9,2 \\
\hline T3 interface água-sedimento & 1,4 & 1,6 & 0,4 & 2,8 & 1,2 & 3,4 & 9,4 \\
\hline $\mathrm{T} 3$ efluente & 1,5 & 3,7 & 0,6 & 4,4 & 0,6 & 4 & 10,8 \\
\hline \multicolumn{8}{|l|}{ 15/07/2005 (20:00 h) } \\
\hline T4 sub-superfície & 1,6 & 2,8 & 0,3 & 3,7 & 3,8 & 3,4 & 9,8 \\
\hline T4 camada intermediária & 1,5 & 1,8 & 0,3 & 0,9 & 3,3 & 2,02 & 11,3 \\
\hline T4 interface água-sedimento & 1,7 & 2,2 & 0,5 & 1,5 & 2,7 & 3,4 & 11,01 \\
\hline T4 efluente & 1,7 & 2,9 & 0,5 & 5,7 & 5,1 & 1,7 & 11,3 \\
\hline
\end{tabular}


Tabela B24: Ácidos orgânicos na lagoa facultativa - Coleta no inverno (julho 2005)

\begin{tabular}{|c|c|c|c|c|c|c|c|}
\hline $\begin{array}{c}\text { Estações de amostragem } \\
\text { (Cajati) }\end{array}$ & $\begin{array}{l}\text { Ácido } \\
\text { acético } \\
\text { (mg/L) }\end{array}$ & $\begin{array}{c}\text { Ácido } \\
\text { propiônico } \\
\text { (mg/L) }\end{array}$ & $\begin{array}{c}\text { Ácido } \\
\text { isobutírico } \\
\text { (mg/L) }\end{array}$ & $\begin{array}{c}\text { Ácido } \\
\text { butírico } \\
\text { (mg/L) }\end{array}$ & $\begin{array}{c}\text { Ácido } \\
\text { isovalérico } \\
\text { (mg/L) }\end{array}$ & $\begin{array}{c}\text { Ácido } \\
\text { valérico } \\
\text { (mg/L) }\end{array}$ & $\begin{array}{c}\text { Ácido } \\
\text { caproico } \\
\text { (mg/L) }\end{array}$ \\
\hline \multicolumn{8}{|l|}{ 12/04/2005 (08:00 h) } \\
\hline T0 sub-superfície & nd & nd & nd & nd & nd & nd & nd \\
\hline T0 camada intermediária & nd & nd & nd & nd & nd & nd & nd \\
\hline $\mathrm{T} 0$ interface água-sedimento & nd & nd & nd & nd & nd & nd & nd \\
\hline T0 efluente & nd & nd & nd & nd & nd & nd & nd \\
\hline \multicolumn{8}{|l|}{ 12/04/2005 (14:00 h) } \\
\hline T1 sub-superfície & nd & nd & nd & nd & nd & nd & nd \\
\hline T1 camada intermediária & nd & nd & nd & nd & nd & nd & nd \\
\hline $\mathrm{T} 1$ interface água-sedimento & nd & nd & nd & nd & nd & nd & nd \\
\hline T1 efluente & nd & nd & nd & 0 & nd & nd & nd \\
\hline \multicolumn{8}{|l|}{ 12/04/2005 (20:00 h) } \\
\hline T2 sub-superfície & 3,8 & nd & nd & nd & nd & nd & nd \\
\hline T2 camada intermediária & nd & nd & nd & nd & nd & nd & nd \\
\hline $\mathrm{T} 2$ interface água-sedimento & 5,2 & nd & nd & nd & nd & nd & nd \\
\hline $\mathrm{T} 2$ efluente & nd & nd & nd & nd & nd & nd & nd \\
\hline \multicolumn{8}{|l|}{ 13/04/2005 (02:00 h) } \\
\hline T3 sub-superfície & nd & nd & nd & nd & nd & nd & nd \\
\hline T3 camada intermediária & nd & nd & nd & nd & nd & nd & nd \\
\hline T3 interface água-sedimento & nd & nd & nd & nd & nd & nd & nd \\
\hline T3 efluente & 3,9 & nd & nd & 0 & nd & nd & nd \\
\hline 13/04/2005 (08:00 h) & nd & nd & nd & nd & nd & nd & nd \\
\hline T4 sub-superfície & 4,3 & nd & nd & nd & nd & nd & nd \\
\hline T4 camada intermediária & nd & nd & nd & nd & nd & nd & nd \\
\hline $\mathrm{T} 4$ interface água-sedimento & nd & nd & nd & nd & nd & nd & nd \\
\hline T4 efluente & 3,3 & nd & nd & nd & nd & nd & nd \\
\hline
\end{tabular}

nd: abaixo do limite de detecção

Valores mínimos detectáveis: ácido acético: 3,1 mg/L; ácido propiônico: 3,2 mg/L; ácido butírico: 0,96 mg/L; ácido isovalérico: $0,47 \mathrm{mg} / \mathrm{L}$; ácido valérico: $0,6 \mathrm{mg} / \mathrm{L}$; ácido caproico: $0,48 \mathrm{mg} / \mathrm{L}$ 
Tabela B25: Dados de precipitação e de temperatura em Cajati

\begin{tabular}{lcc}
\hline $\begin{array}{c}\text { Data } \\
\text { (mensal) }\end{array}$ & $\begin{array}{c}\text { Precipitação } \\
(\mathbf{m m})\end{array}$ & $\begin{array}{c}\text { Temperatura } \\
\left({ }^{\circ} \mathbf{C}\right)\end{array}$ \\
Set/04 & 47 & 22,6 \\
Out/04 & 201 & 21,9 \\
Nov/04 & 134 & 23,8 \\
Dez/04 & 394 & 24,3 \\
Jan/05 & 305 & 25,8 \\
Fev/05 & 123 & 25,2 \\
Mar/05 & 316 & 26,1 \\
Abr/05 & 115 & 24,3 \\
Mai/05 & 104 & 22,1 \\
Jun/05 & 40 & 21,3 \\
Jul/05 & 119 & 17,7 \\
Ago/05 & 73,4 & 19,8 \\
Máx & 394 & 26,1 \\
Mín & 40 & 17,7 \\
\hline
\end{tabular}




\section{C.1.1. Análise estatística: Lagoa anaeróbia}

Foi realizada análise de variância (ANOVA, da versão 7 do EXCEL) para verificar remoção de nitrogênio amoniacal, nitrito e nitrato na lagoa anaeróbia, nos horários T1 e T3, para os diferentes pontos de coleta e épocas do ano. Não foram verificadas diferenças significativas entre os dois horários, pontos de coleta e épocas do ano $(p=0,615)$ (Tabelas C1 e C2).

Tabela C1: Teste F univariado avaliando T1 e T3 nos diferentes pontos de coleta e épocas do ano

\begin{tabular}{l|ccccc}
\hline \multicolumn{1}{c|}{ Fonte } & SS & df & MS & F & P \\
\hline Nitrogênio amoniacal & 0,032 & 1 & 0,032 & 0,856 & 0,365 \\
Error & 0,820 & 22 & 0,037 & & \\
Nitrito & 0,000 & 1 & 0,000 & 3,606 & 0,071 \\
Error & 0,000 & 22 & 0,000 & & \\
Nitrato & 0,084 & 1 & 0,084 & 3,621 & 0,070 \\
Error & 0,509 & 22 & 0,023 & & \\
\hline
\end{tabular}

Tabela C2: Análise estatística multivariada avaliando T1 e T3, nos diferentes pontos de coleta e épocas do ano

\begin{tabular}{l|cccc}
\hline \multicolumn{1}{c|}{ Estatística } & Valor-P & F-estatístico & df & Probabilidade \\
\hline Wilks' Lambda & 0,615 & 4,167 & 3,20 & 0,019 \\
Pillai Trace & 0,385 & 4,167 & 3,20 & 0,019 \\
Hotelline-Lawley & 0,625 & 4,167 & 3,20 & 0,019 \\
Trace & & & & \\
\hline
\end{tabular}

Foi realizada análise de variância e não foram verificadas diferenças significativas, na remoção de nitrogênio amoniacal, nitrito e nitrato, nas diferentes épocas do ano $(\mathrm{p}=0,182)($ Tabelas $\mathrm{C} 3$ e $\mathrm{C} 4)$.

Tabela C3: Teste F univariado avaliando as coletas nas diferentes épocas do ano

\begin{tabular}{l|ccccc}
\hline \multicolumn{1}{c|}{ Fonte } & SS & df & MS & F & P \\
\hline Nitrogênio amoniacal & 0,471 & 3 & 0,157 & 8,262 & 0,001 \\
Error & 0,380 & 20 & 0,019 & & \\
Nitrito & 0,000 & 3 & 0,000 & 4,831 & 0,011 \\
Error & 0,000 & 20 & 0,000 & & \\
Nitrato & 0,096 & 3 & 0,032 & 1,290 & 0,305 \\
Error & 0,497 & 20 & 0,025 & & \\
\hline
\end{tabular}


Tabela C4: Análise estatística multivariada avaliando as coletas nas diferentes épocas do ano

\begin{tabular}{l|cccc}
\hline \multicolumn{1}{c|}{ Estatística } & Valor-P & F-estatístico & df & Probabilidade \\
\hline Wilks' Lambda & 0,182 & 4,958 & 9,43 & 0,000 \\
Pillai Trace & 1,136 & 4,065 & 9,60 & 0,000 \\
Hotelling-Lawley & 2,908 & 5,386 & 9,50 & 0,000 \\
Trace & & & & \\
\hline
\end{tabular}

Realizando análise de variância, não foram verificadas diferenças significativas, na remoção de nitrogênio amoniacal, nitrito e nitrato, na primavera e inverno (período de seca), e outono e verão (período de chuva), sendo valor de p=0,543 (Tabelas C6 e C7).

Tabela C5: Teste F univariado avaliando diferenças na sazonalidade (seca e chuva)

\begin{tabular}{l|ccccc}
\hline \multicolumn{1}{c|}{ Fonte } & SS & df & MS & F & P \\
\hline Nitrogênio amoniacal & 0,312 & 1 & 0,312 & 12,718 & 0,002 \\
Error & 0,540 & 22 & 0,025 & & \\
Nitrito & 0,000 & 1 & 0,000 & 0,414 & 0,527 \\
Error & 0,000 & 22 & 0,000 & & \\
Nitrato & 0,049 & 1 & 0,049 & 1,968 & 0,175 \\
Error & 0,544 & 22 & 0,025 & & \\
\hline
\end{tabular}

Tabela C6: Análise estatística multivariada avaliando diferenças na sazonalidade (seca e chuva)

\begin{tabular}{l|cccc}
\hline \multicolumn{1}{c|}{ Estatística } & Valor-P & F-estatístico & df & Probabilidade \\
\hline Wilks' Lambda & 0,543 & 5,613 & 3,20 & 0,006 \\
Pillai Trace & 0,457 & 5,613 & 3,20 & 0,006 \\
$\begin{array}{l}\text { Hotelling-Lawley } \\
\text { Trace }\end{array}$ & 0,842 & 5,613 & 3,20 & 0,006 \\
\hline
\end{tabular}

Realizando análise de variância, não foram verificadas diferenças significativas, na remoção de nitrogênio amoniacal, nitrito e nitrato, nos diferentes pontos de coleta $(p=0,764)($ Tabelas C7 e C8). 
Tabela C7: Teste $\mathrm{F}$ univariado avaliando os diferentes pontos de coleta

\begin{tabular}{l|ccccc}
\hline \multicolumn{1}{c|}{ Fonte } & SS & df & MS & F & P \\
\hline Nitrogênio amoniacal & 0,191 & 2 & 0,095 & 3,026 & 0,070 \\
Error & 0,661 & 21 & 0,031 & & \\
Nitrito & 0,000 & 2 & 0,000 & 0,064 & 0,938 \\
Error & 0,000 & 21 & 0,000 & & \\
Nitrato & 0,000 & 2 & 0,000 & 0,003 & 0,997 \\
Error & 0,592 & 21 & 0,028 & & \\
\hline
\end{tabular}

Tabela C8: Análise estatística multivariada avaliando os diferentes pontos de coleta

\begin{tabular}{l|cccc}
\hline \multicolumn{1}{c|}{ Estatística } & Valor-P & F-estatístico & df & Probabilidade \\
\hline Wilks' Lambda & 0,764 & 0,911 & 6,38 & 0,498 \\
Pillai Trace & 0,237 & 0,894 & 6,40 & 0,508 \\
Hotelling-Lawley & 0,307 & 0,922 & 6,36 & 0,491 \\
Trace & & & & \\
\hline
\end{tabular}

\section{1. 2. Análise estatística: Lagoa facultativa}

Aplicando análise de variância, não foram verificadas diferenças significativas, na remoção de nitrogênio amoniacal, nitrito e nitrato, entre os dois horários de coleta realizados (T1 e T3), nos diferentes pontos de coleta e épocas do ano $(\mathrm{p}=0,989)$ (Tabelas C9 e C10).

Tabela C9: Teste $\mathrm{F}$ univariado avaliando $\mathrm{T} 1$ e $\mathrm{T} 3$ nos diferentes pontos de coleta e épocas do ano

\begin{tabular}{l|ccccc}
\hline \multicolumn{1}{c|}{ Fonte } & SS & df & MS & F & P \\
\hline Nitrogênio amoniacal & 0,005 & 1 & 0,005 & 0,032 & 0,860 \\
Error & 3,125 & 22 & 0,142 & & \\
Nitrito & 0,000 & 1 & 0,000 & 0,069 & 0,796 \\
Error & 0,000 & 22 & 0,000 & & \\
Nitrato & 0,001 & 1 & 0,001 & 0,235 & 0,633 \\
Error & 0,114 & 22 & 0,005 & & \\
\hline
\end{tabular}

Tabela C10: Análise estatística multivariada avaliando T1 e T3 nos diferentes pontos de coleta e épocas do ano

\begin{tabular}{l|cccc}
\hline \multicolumn{1}{c|}{ Estatística } & Valor-P & F-estatístico & df & Probabilidade \\
\hline Wilks' Lambda & 0,989 & 0,077 & 3,20 & 0,972 \\
Pillai Trace & 0,011 & 0,077 & 3,20 & 0,972 \\
Hotelling-Lawley & 0,012 & 0,077 & 3,20 & 0,972 \\
Trace & & & & \\
\hline
\end{tabular}


Realizando análise de variância foram verificados diferenças significativas na remoção de nitrogênio amoniacal, nitrito e nitrato, nas coletas realizadas nas diferentes épocas do ano $(\mathrm{p}=0,010)$ (Tabelas $\mathrm{C} 11$ e C12).

Tabela C11: Teste F univariado avaliando as coletas nas diferentes épocas do ano

\begin{tabular}{l|ccccc}
\hline \multicolumn{1}{c|}{ Fonte } & SS & df & MS & F & P \\
\hline Nitrogênio amoniacal & 2,619 & 3 & 0,873 & 34,194 & 0,000 \\
Error & 0,511 & 20 & 0,026 & & \\
Nitrito & 0,000 & 3 & 0,000 & 9,475 & 0,000 \\
Error & 0,000 & 20 & 0,000 & & \\
Nitrato & 0,097 & 3 & 0,032 & 35,91 & 0,000 \\
Error & 0,018 & 20 & 0,001 & & \\
\hline
\end{tabular}

Tabela C12: Análise estatística multivariada avaliando as coletas nas diferentes épocas do ano

\begin{tabular}{l|cccc}
\hline \multicolumn{1}{c|}{ Estatística } & Valor-P & F-estatístico & df & Probabilidade \\
\hline Wilks' Lambda & 0,010 & 27,385 & 9,43 & 0,000 \\
Pillai Trace & 2,220 & 18,967 & 9,60 & 0,000 \\
Hotelling-Lawley & 13,117 & 24,291 & 9,50 & 0,000 \\
Trace & & & & \\
\hline
\end{tabular}

Aplicando o teste estatístico ANOVA, não foram verificadas diferenças significativas, na remoção de nitrogênio amoniacal, nitrito e nitrato, entre as coletas realizadas na primavera e inverno (seca) e outono e verão (cheia), sendo valor de $p=0,240$ (Tabelas C13 e C14).

Tabela C13: Teste F univariado avaliando diferenças na sazonalidade (seca e chuva)

\begin{tabular}{l|ccccc}
\hline \multicolumn{1}{c|}{ Fonte } & SS & df & MS & F & P \\
\hline Nitrogênio amoniacal & 0,000 & 1 & 0,000 & 0,000 & 0,991 \\
Error & 3,129 & 22 & 0,142 & & \\
Nitrito & 0,000 & 1 & 0,000 & 15,099 & 0,001 \\
Error & 0,000 & 22 & 0,000 & & \\
Nitrato & 0,071 & 1 & 0,071 & 35,246 & 0,000 \\
Error & 0,044 & 22 & 0,002 & & \\
\hline
\end{tabular}


Tabela C14: Análise estatística multivariada avaliando diferenças na sazonalidade (seca e chuva)

\begin{tabular}{l|cccc}
\hline \multicolumn{1}{c|}{ Estatística } & Valor-P & F-estatístico & df & Probabilidade \\
\hline Wilks' Lambda & 0,240 & 21,128 & 3,20 & 0,000 \\
Pillai Trace & 0,760 & 21,128 & 3,20 & 0,000 \\
Hotelling-Lawley & 3,169 & 21,128 & 3,20 & 0,000 \\
Trace & & & & \\
\hline
\end{tabular}

Como foram verificados diferenças significativas, na remoção de nitrogênio amoniacal, nitrito e nitrato, nas diferentes épocas do ano, foi realizada análise de variância para cada estação do ano, separadamente.

\section{Primavera}

Realizando análise de variância foram verificados diferenças significativas, na remoção de nitrogênio amoniacal, nitrito e nitrato, entre os dois horários de coleta (T1 e T3), com valor de $\mathrm{p}=0,045$ (Tabelas C15 e C16).

Tabela C15: Teste F univariado avaliando T1 e T3 na primavera

\begin{tabular}{l|ccccc}
\hline \multicolumn{1}{c|}{ Fonte } & SS & df & MS & F & P \\
\hline Nitrogênio amoniacal & 0,017 & 1 & 0,017 & 5,487 & 0,079 \\
Error & 0,013 & 4 & 0,003 & & \\
Nitrito & 0,000 & 1 & 0,000 & 18,004 & 0,013 \\
Error & 0,000 & 4 & 0,000 & & \\
Nitrato & 0,000 & 1 & 0,000 & 2,969 & 0,160 \\
Error & 0,001 & 4 & 0,000 & & \\
\hline
\end{tabular}

Tabela C16: Análise estatística multivariada avaliando T1 e T3 na primavera

\begin{tabular}{l|cccc}
\hline \multicolumn{1}{c|}{ Estatística } & Valor-P & F-estatístico & df & Probabilidade \\
\hline Wilks' Lambda & 0,045 & 14,213 & 3,2 & 0,066 \\
Pillai Trace & 0,955 & 14,213 & 3,2 & 0,066 \\
$\begin{array}{l}\text { Hotelling-Lawley } \\
\text { Trace }\end{array}$ & 21,319 & 14,213 & 3,2 & 0,066 \\
\hline
\end{tabular}


Realizando análise de variância, não foram verificadas diferenças significativas, na remoção de nitrogênio amoniacal, nitrito e nitrato, entre os diferentes pontos de coleta $(\mathrm{p}=0,251)($ Tabelas $\mathrm{C} 17$ e C18).

Tabela C17: Teste $\mathrm{F}$ univariado avaliando os diferentes pontos de coleta

\begin{tabular}{l|ccccc}
\hline \multicolumn{1}{c|}{ Fonte } & SS & df & MS & F & P \\
\hline Nitrogênio amoniacal & 0,006 & 2 & 0,003 & 0,372 & 0,717 \\
Error & 0,024 & 3 & 0,008 & & \\
Nitrito & 0,000 & 2 & 0,000 & 0,071 & 0,933 \\
Error & 0,000 & 3 & 0,000 & & \\
Nitrato & 0,000 & 2 & 0,000 & 0,100 & 0,908 \\
Error & 0,001 & 3 & 0,000 & & \\
\hline
\end{tabular}

Tabela C18: Análise estatística multivariada avaliando os diferentes pontos de coleta

\begin{tabular}{l|cccc}
\hline \multicolumn{1}{c|}{ Estatística } & Valor-P & F-estatístico & df & Probabilidade \\
\hline Wilks' Lambda & 0,251 & 0,331 & 6,2 & 0,876 \\
Pillai Trace & 0,785 & 0,431 & 6,4 & 0,829 \\
$\begin{array}{l}\text { Hotelling-Lawley } \\
\text { Trace }\end{array}$ & 2,830 & 0,000 & 6,0 & \\
\hline
\end{tabular}

\section{Verão}

Aplicando o teste estatístico ANOVA, não foram verificadas diferenças significativas, na remoção de nitrogênio amoniacal, nitrito e nitrato, entre os dois horários de coleta (T1 e T3), com valor de p=0,342 (Tabelas C19 e C20).

Tabela C19: Teste F univariado avaliando T1 e T3

\begin{tabular}{l|ccccc}
\hline \multicolumn{1}{c|}{ Fonte } & SS & df & MS & F & P \\
\hline Nitrogênio amoniacal & 0,015 & 1 & 0,015 & 0,545 & 0,501 \\
Error & 0,112 & 4 & 0,028 & & \\
Nitrito & 0,000 & 1 & 0,000 & 0,039 & 0,853 \\
Error & 0,000 & 4 & 0,000 & & \\
Nitrato & 0,006 & 1 & 0,006 & 3,579 & 0,131 \\
Error & 0,006 & 4 & 0,002 & & \\
\hline
\end{tabular}

Tabela C20: Análise estatística multivariada avaliando T1 e T3

\begin{tabular}{l|cccc}
\hline \multicolumn{1}{c|}{ Estatística } & Valor-P & F-estatístico & df & Probabilidade \\
\hline Wilks' Lambda & 0,342 & 1,284 & 3,2 & 0,466 \\
Pillai Trace & 0,658 & 1,284 & 3,2 & 0,466 \\
Hotelling-Lawley & 1,926 & 1,284 & 3,2 & 0,466 \\
Trace & & & & \\
\hline
\end{tabular}


Realizando análise de variância, foram verificadas diferenças significativas, na remoção de nitrogênio amoniacal, nitrito e nitrato, entre os diferentes pontos de coleta, com valor de $\mathrm{p}=0,048$ (Tabelas C21 e C22).

Tabela C21: Teste F univariado avaliando os diferentes pontos de coleta

\begin{tabular}{l|ccccc}
\hline \multicolumn{1}{c|}{ Fonte } & SS & df & MS & F & P \\
\hline Nitrogênio amoniacal & 0,095 & 2 & 0,048 & 4,433 & 0,127 \\
Error & 0,032 & 3 & 0,011 & & \\
Nitrito & 0,000 & 2 & 0,000 & 6,473 & 0,082 \\
Error & 0,000 & 3 & 0,000 & & \\
Nitrato & 0,005 & 2 & 0,002 & 0,968 & 0,474 \\
Error & 0,007 & 3 & 0,002 & & \\
\hline
\end{tabular}

Tabela C22: Análise estatística multivariada avaliando os diferentes pontos de coleta

\begin{tabular}{l|cccc}
\hline \multicolumn{1}{c|}{ Estatística } & Valor-P & F-estatístico & df & Probabilidade \\
\hline Wilks' Lambda & 0,048 & 1,184 & 6,2 & 0,525 \\
Pillai Trace & 1,295 & 1,224 & 6,4 & 0,442 \\
$\begin{array}{l}\text { Hotelling-Lawley } \\
\text { Trace }\end{array}$ & 12,614 & 0,000 & 6,0 & \\
\hline
\end{tabular}

\section{Outono}

Realizando análise de variância, não foram verificadas diferenças significativas, na remoção de nitrogênio amoniacal, nitrito e nitrato, entre os dois horários de coleta (T1 e T3), sendo $\mathrm{p}=0,126$ (Tabelas C23 e C24).

Tabela C23: Teste F univariado avaliando T1 e T3

\begin{tabular}{l|ccccc}
\hline \multicolumn{1}{c|}{ Fonte } & SS & df & MS & F & P \\
\hline Nitrogênio amoniacal & 0,070 & 1 & 0,070 & 1,103 & 0,353 \\
Error & 0,252 & 4 & 0,063 & & \\
Nitrito & 0,000 & 1 & 0,000 & 4,001 & 0,116 \\
Error & 0,000 & 4 & 0,000 & & \\
Nitrato & 0,000 & 1 & 0,000 & 0,262 & 0,636 \\
Error & 0,003 & 4 & 0,001 & & \\
\hline
\end{tabular}

Tabela C24: Análise estatística multivariada avaliando T1 e T3

\begin{tabular}{l|cccc}
\hline \multicolumn{1}{c|}{ Estatística } & Valor-P & F-estatístico & df & Probabilidade \\
\hline Wilks' Lambda & 0,126 & 4,617 & 3,2 & 0,183 \\
Pillai Trace & 0,874 & 4,617 & 3,2 & 0,183 \\
Hotelling-Lawley & 6,925 & 4,617 & 3,2 & 0,183 \\
Trace & & & & \\
\hline
\end{tabular}


Realizando análise de variância, foram verificadas diferenças significativas, na remoção de nitrogênio amoniacal, nitrito e nitrato, entre os diferentes pontos de coleta $(p=0,004)($ Tabelas C25 e C26).

Tabela C25: Teste $\mathrm{F}$ univariado avaliando os diferentes pontos de coleta

\begin{tabular}{l|ccccc}
\hline \multicolumn{1}{c|}{ Fonte } & SS & df & MS & F & P \\
\hline Nitrogênio amoniacal & 0,147 & 2 & 0,074 & 1,265 & 0,400 \\
Error & 0,175 & 3 & 0,058 & & \\
Nitrito & 0,000 & 2 & 0,000 & 0,500 & 0,650 \\
Error & 0,000 & 3 & 0,000 & & \\
Nitrato & 0,002 & 2 & 0,001 & 1,553 & 0,344 \\
Error & 0,002 & 3 & 0,001 & & \\
\hline
\end{tabular}

Tabela C26: Análise estatística multivariada avaliando os diferentes pontos de coleta

\begin{tabular}{l|cccc}
\hline \multicolumn{1}{c|}{ Estatística } & Valor-P & F-estatístico & df & Probabilidade \\
\hline Wilks' Lambda & 0,004 & 4,968 & 6,2 & 0,177 \\
Pillai Trace & 1,250 & 1,112 & 6,4 & 0,481 \\
$\begin{array}{l}\text { Hotelling-Lawley } \\
\text { Trace }\end{array}$ & 187,622 & 0,000 & 6,0 & \\
\hline
\end{tabular}

\section{Inverno}

Realizando análise de variância, não foram verificadas diferenças significativas, na remoção de nitrogênio amoniacal, nitrito e nitrato, entre os dois horários de coleta (T1 e T3), com p=0,173 (Tabelas C27 e C28).

Tabela C27: Teste F univariado avaliando T1 e T3

\begin{tabular}{l|ccccc}
\hline \multicolumn{1}{c|}{ Fonte } & SS & df & MS & F & P \\
\hline Nitrogênio amoniacal & 0,015 & 1 & 0,015 & 3,569 & 0,132 \\
Error & 0,016 & 4 & 0,004 & & \\
Nitrito & 0,000 & 1 & 0,000 & 2,000 & 0,230 \\
Error & 0,000 & 4 & 0,000 & & \\
Nitrato & 0,000 & 1 & 0,000 & 0,606 & 0,480 \\
Error & 0,001 & 4 & 0,000 & & \\
\hline
\end{tabular}

Tabela C28: Análise estatística multivariada avaliando T1 e T3

\begin{tabular}{l|cccc}
\hline \multicolumn{1}{c|}{ Estatística } & Valor-P & F-estatístico & df & Probabilidade \\
\hline Wilks' Lambda & 0,173 & 3,193 & 3,2 & 0,248 \\
Pillai Trace & 0,827 & 3,193 & 3,2 & 0,248 \\
Hotelling-Lawley & 4,789 & 3,193 & 3,2 & 0,248 \\
Trace & & & & \\
\hline
\end{tabular}


Realizando análise de variância, não foram verificadas diferenças significativas, na remoção de nitrogênio amoniacal, nitrito e nitrato, entre os diferentes pontos de coleta $(p=0,176)($ Tabelas C29 e C30).

Tabela C29: Teste F univariado avaliando os diferentes pontos de coleta

\begin{tabular}{l|ccccc}
\hline \multicolumn{1}{c|}{ Fonte } & SS & df & MS & F & P \\
\hline Nitrogênio amoniacal & 0,005 & 2 & 0,002 & 0,289 & 0,768 \\
Error & 0,026 & 3 & 0,009 & & \\
Nitrito & 0,000 & 2 & 0,000 & 0,000 & 1,000 \\
Error & 0,000 & 3 & 0,000 & & \\
Nitrato & 0,001 & 2 & 0,000 & 1,226 & 0,408 \\
Error & 0,001 & 3 & 0,000 & & \\
\hline
\end{tabular}

Tabela C30: Análise estatística multivariada avaliando os diferentes pontos de coleta

\begin{tabular}{l|cccc}
\hline \multicolumn{1}{c|}{ Estatística } & Valor-P & F-estatístico & df & Probabilidade \\
\hline Wilks' Lambda & 0,176 & 0,461 & 6,2 & 0,805 \\
Pillai Trace & 0,904 & 0,550 & 6,4 & 0,756 \\
Hotelling-Lawley & 4,220 & 0,000 & 6,0 & \\
Trace & & & & \\
\hline
\end{tabular}

\section{C.1.3. Análise estatística comparando as lagoas anaeróbia e facultativa}

Realizando análise de variância, não foram verificadas diferenças significativas entre as lagoas anaeróbia e facultativa, na remoção de nitrogênio amoniacal, nitrito e nitrato, nos dois horários de coleta, e diferentes pontos de amostragem e épocas do ano $(p=0,548)$ (Tabelas C31 e C32).

Tabela C31: Teste F univariado avaliando T1 e T3, pontos de coleta e épocas do ano

\begin{tabular}{l|ccccc}
\hline \multicolumn{1}{c|}{ Fonte } & SS & df & MS & F & P \\
\hline Nitrogênio amoniacal & 3,217 & 1 & 3,217 & 37,179 & 0,000 \\
Error & 3,981 & 46 & 0,087 & & \\
Nitrito & 0,000 & 1 & 0,000 & 0,035 & 0,852 \\
Error & 0,000 & 46 & 0,000 & & \\
Nitrato & 0,020 & 1 & 0,020 & 1,322 & 0,256 \\
Error & 0,708 & 46 & 0,015 & & \\
\hline
\end{tabular}


Tabela C32: Análise estatística multivariada avaliando T1 e T3, pontos de coleta e épocas do ano

\begin{tabular}{l|cccc}
\hline \multicolumn{1}{c|}{ Estatística } & Valor-P & F-estatístico & df & Probabilidade \\
\hline Wilks' Lambda & 0,548 & 12,085 & 3,44 & 0,000 \\
Pillai Trace & 0,452 & 12,085 & 3,44 & 0,000 \\
Hotelling-Lawley & 0,824 & 12,085 & 3,44 & 0,000 \\
Trace & & & & \\
\hline
\end{tabular}

Realizando análise de variância, não foram verificadas diferenças significativas entre as lagoas anaeróbia e facultativa, nos dois horários de coleta (T1 e T3), com p=0,606 (Tabelas C33 e C34).

Tabela C33: Teste F univariado avaliando T1 e T3

\begin{tabular}{l|ccccc}
\hline \multicolumn{1}{c|}{ Fonte } & SS & df & MS & F & P \\
\hline Nitrogênio amoniacal & 1,783 & 2 & 0,892 & 7,409 & 0,002 \\
Error & 5,415 & 45 & 0,120 & & \\
Nitrito & 0,000 & 2 & 0,000 & 1,493 & 0,236 \\
Error & 0,000 & 45 & 0,000 & & \\
Nitrato & 0,036 & 2 & 0,018 & 1,176 & 0,318 \\
Error & 0,692 & 45 & 0,015 & & \\
\hline
\end{tabular}

Tabela C34: Análise estatística multivariada avaliando T1 e T3

\begin{tabular}{l|cccc}
\multicolumn{1}{c|}{ Estatística } & Valor-P & F-estatístico & df & Probabilidade \\
\hline Wilks' Lambda & 0,606 & 4,083 & 6,86 & 0,001 \\
Pillai Trace & 0,420 & 3,902 & 6,88 & 0,002 \\
Hotelling-Lawley & 0,608 & 4,256 & 6,84 & 0,001 \\
Trace & & & & \\
\hline
\end{tabular}

Realizando análise de variância, não foram verificadas diferenças significativas entre as lagoas anaeróbia e facultativa, nas diferentes épocas do ano, com $\mathrm{p}=0,517$ (Tabelas C35 e C36).

Tabela C35: Teste F univariado entre os diferentes pontos de coleta

\begin{tabular}{l|ccccc}
\hline \multicolumn{1}{c|}{ Fonte } & SS & df & MS & F & P \\
\hline Nitrogênio amoniacal & 1,844 & 3 & 0,615 & 5,051 & 0,004 \\
Error & 5,354 & 44 & 0,122 & & \\
Nitrito & 0,000 & 3 & 0,000 & 5,611 & 0,002 \\
Error & 0,000 & 44 & 0,000 & & \\
Nitrato & 0,003 & 3 & 0,001 & 0,061 & 0,98 \\
Error & 0,725 & 44 & 0,016 & & \\
\hline
\end{tabular}


Tabela C36: Análise estatística multivariada

\begin{tabular}{l|cccc}
\hline \multicolumn{1}{c|}{ Estatística } & Valor-P & F-estatístico & df & Probabilidade \\
\hline Wilks' Lambda & 0,517 & 3,546 & 9,102 & 0,001 \\
Pillai Trace & 0,544 & 3,249 & 9,132 & 0,001 \\
$\begin{array}{l}\text { Hotelling-Lawley } \\
\text { Trace }\end{array}$ & 0,818 & 3,697 & 9,122 & 0,000 \\
\hline
\end{tabular}

Realizando análise de variância, não foram verificadas diferenças significativas entre as lagoas anaeróbia e facultativa, nos diferentes pontos de coleta, com $\mathrm{p}=0,949$ (Tabelas C37 e C38).

Tabela C37: Teste $\mathrm{F}$ univariado avaliando os diferentes pontos de coleta

\begin{tabular}{l|ccccc}
\hline \multicolumn{1}{c|}{ Fonte } & SS & df & MS & F & P \\
\hline Nitrogênio amoniacal & 0,261 & 2 & 0,130 & 0,845 & 0,436 \\
Error & 6,938 & 45 & 0,154 & & \\
Nitrito & 0,000 & 2 & 0,000 & 0,363 & 0,698 \\
Error & 0,000 & 45 & 0,000 & & \\
Nitrato & 0,001 & 2 & 0,001 & 0,032 & 0,968 \\
Error & 0,727 & 45 & 0,016 & & \\
\hline
\end{tabular}

Tabela C38: Análise estatística multivariada avaliando os diferentes pontos de coleta

\begin{tabular}{l|cccc}
\hline \multicolumn{1}{c|}{ Estatística } & Valor-P & F-estatístico & df & Probabilidade \\
\hline Wilks' Lambda & 0,949 & 0,383 & 6,86 & 0,888 \\
Pillai Trace & 0,052 & 0,388 & 6,88 & 0,885 \\
Hotelling-Lawley & 0,054 & 0,378 & 6,84 & 0,891 \\
Trace & & & & \\
\hline
\end{tabular}

Finalmente, na lagoa anaeróbia, não foram verificados diferenças significativas, na remoção de nitrogênio amoniacal, nitrito e nitrato, entre os horários $\mathrm{T} 1 \mathrm{e} T 3$, pontos de coleta e épocas do ano, assim como, nos períodos de seca e chuva. Esses resultados indicaram que, remoção dessas formas de nitrogênio pelos microrganismos existentes na lagoa, foi independente do horário, pontos de amostragem e épocas do ano.

$\mathrm{Na}$ lagoa facultativa, foram verificados diferenças significativas na remoção de nitrogênio amoniacal, nitrito e nitrato, nas diferentes épocas do ano $(\mathrm{p}<0,05)$, significando que, remoção dessas formas de nitrogênio pelos diferentes microrganismos presentes na lagoa, foi dependente da estação do ano e das diferentes condições físico-químicos característicos de cada época em particular. Na primavera foram verificadas diferenças 
significativas, entre os dois horários de coleta ( $\mathrm{T} 1$ e $\mathrm{T} 3$ ), indicando que, foi diferente a remoção de nitrogênio amoniacal, nitrito e nitrato, em ambos os horários de coleta, devido, possivelmente, a presença de chuva, vento e outros fatores físico-químicos, no horário T3. No verão e outono foram verificados diferenças significativas, na remoção de nitrogênio amoniacal, nitrito e nitrato, entre os diferentes pontos de coleta, devido, possivelmente, ao maior valor de oxigênio dissolvido e temperatura na sub-superfície (variaram de 2,29 mg/L a $9,54 \mathrm{mg} / \mathrm{L}$ e $28,75^{\circ} \mathrm{C}$ a $34,31^{\circ} \mathrm{C}$, respectivamente) que nos outros pontos de coleta, que favoreceram o processo da nitrificação na lagoa facultativa.

Comparando as lagoas anaeróbia e facultativa, não foram verificadas diferenças significativas entre as lagoas, na remoção de nitrogênio amoniacal, nitrito e nitrato, nos dois horários de coleta, diferentes pontos de amostragem e épocas do ano. Significa que, remoção dessas formas de nitrogênio foi similar, devido, possivelmente, aos valores físicoquímicos máximos e mínimos serem semelhantes em ambas as lagoas. 